\title{
EDUGACG̃O GONTEMPORÂNEA
}

\section{Educação Básica}

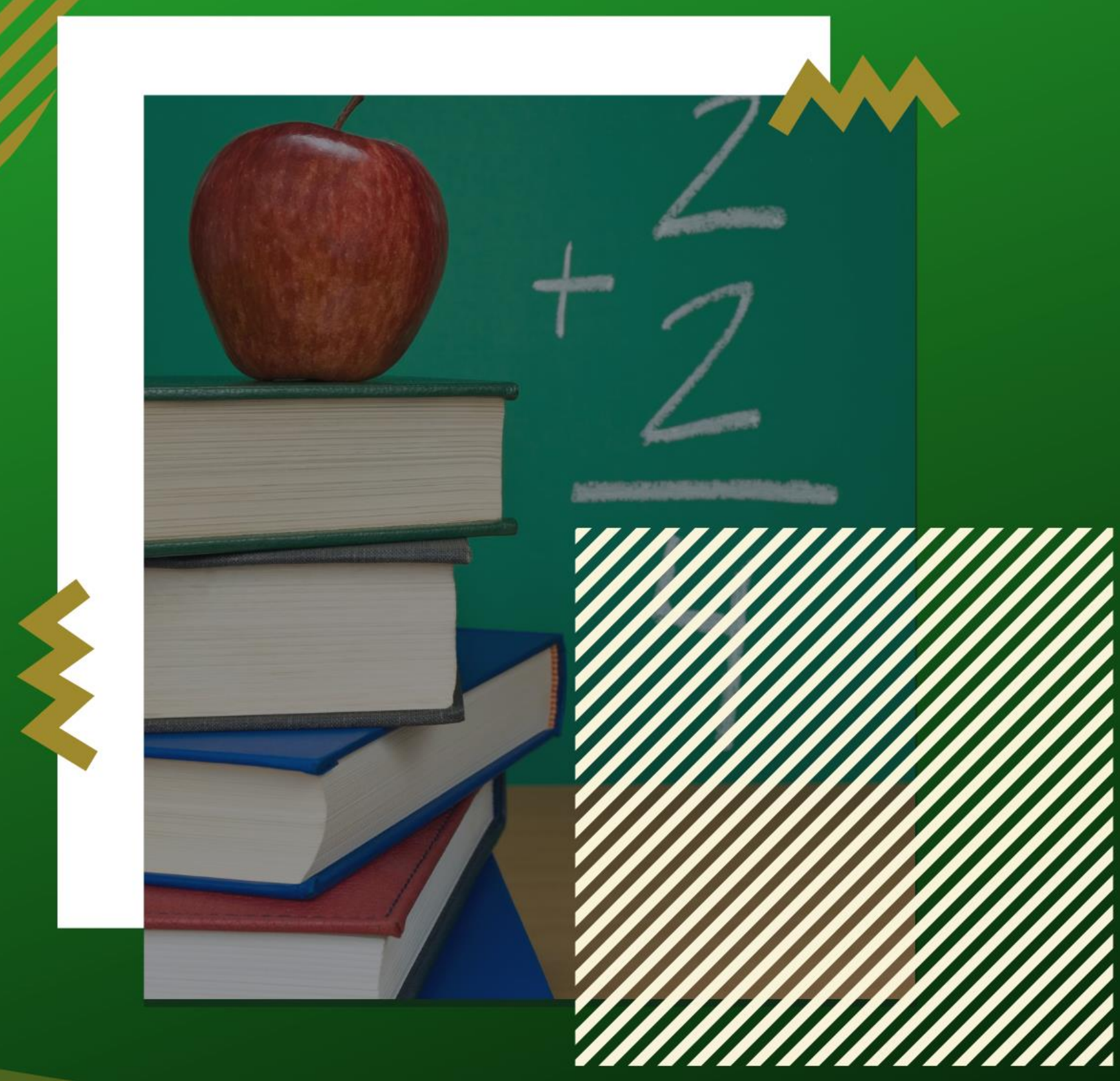

Organizadoras

Maria Célia da Silva Gonçalves

Bruna Guzman de Jesus
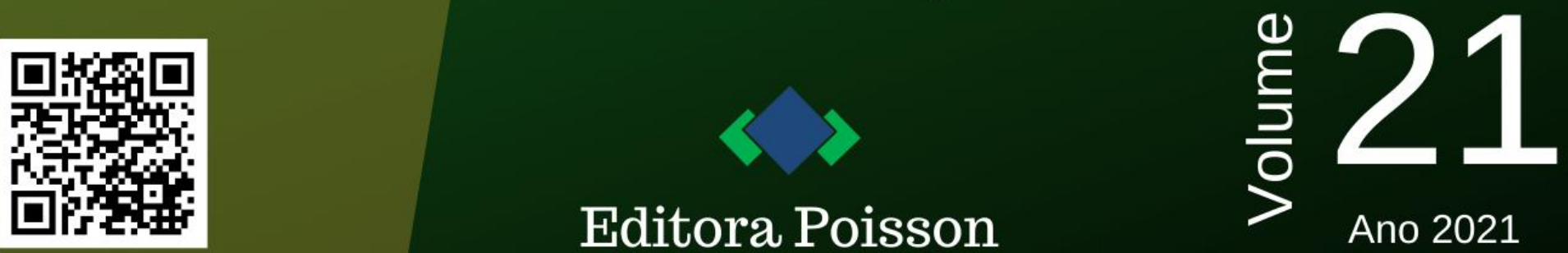
Maria Célia da Silva Gonçalves

Bruna Guzman de Jesus

(Organizadoras)

\title{
Educação Contemporânea - Volume 21 Educação Básica
}

\author{
1․ Edição \\ Belo Horizonte \\ Poisson
}

2021 


\section{Editor Chefe: Dr. Darly Fernando Andrade}

\section{Conselho Editorial}

Dr. Antônio Artur de Souza - Universidade Federal de Minas Gerais

Ms. Davilson Eduardo Andrade

Dra. Elizângela de Jesus Oliveira - Universidade Federal do Amazonas

Msc. Fabiane dos Santos

Dr. José Eduardo Ferreira Lopes - Universidade Federal de Uberlândia

Dr. Otaviano Francisco Neves - Pontifícia Universidade Católica de Minas Gerais

Dr. Luiz Cláudio de Lima - Universidade FUMEC

Dr. Nelson Ferreira Filho - Faculdades Kennedy

Ms. Valdiney Alves de Oliveira - Universidade Federal de Uberlândia

\section{Dados Internacionais de Catalogação na Publicação (CIP)}

E24 Educação Contemporânea - Volume 21 - Educação Básica/ Organização:
GONÇALVES, Maria Célia da Silva; JESUS, Bruna Guzman de - Belo
Horizonte- MG: Poisson,2021
Formato: PDF
ISBN: 978-65-5866-047-7
DOI: 10.36229/978-65-5866-047-7
Modo de acesso: World Wide Web
Inclui bibliografia
1.História 2.Educação I. GONÇALVES, Maria Célia da Silva II.JESUS,
Bruna Guzman. III.Título
Sônia Márcia Soares de Moura - CRB 6/1896
CDD-370

O conteúdo dos artigos e seus dados em sua forma, correção e confiabilidade são de responsabilidade exclusiva dos seus respectivos autores

www.poisson.com.br

contato@poisson.com.br 


\section{SUMÁRIO}

Capítulo 1: Família e escola: Desafios e perspectivas para a gestão escolar 08 Danieli Martins Ambrós, Maritiele de Araújo Borges, Juliane Marschall Morgenstern DOI: $10.36229 / 978-65-5866-047-7 . C A P .01$

Capítulo 2: A gestão em sala de aula na experiência de estágio curricular nos anos iniciais do Ensino Fundamental 15

Wilvania Carvalho de Souza Paiva, Eunice Maria da Silva

DOI: 10.36229/978-65-5866-047-7.CAP.02

Capítulo 3: As influências da relação pedagógica professor-aluno no processo de ensinoaprendizagem no Ensino Fundamental 24

Juliana de Souza Costa, Edileuza Fernandes Silva

DOI: $10.36229 / 978-65-5866-047-7 . C A P .03$

Capítulo 4: Panorama das pesquisas sobre interdisciplinaridade na Educação Básica 32

Camila Aparecida Silva Rosa Marinelo, Giovanna Velloso dos Santos, Márcia Maria Dias Reis Pacheco DOI: 10.36229/978-65-5866-047-7.CAP.04

Capítulo 5: A indisciplina escolar na Educação Infantil: Desafios e possibilidades na sala de aula. 38

Maria Madalena de Melo Feliciano

DOI: $10.36229 / 978-65-5866-047-7 . C A P .05$

Capítulo 6: Pensando processos de formação para educadores(AS) da Educação Infantil 46

Marilei Almeida de Oliveira, Graziela Escandiel de Lima

DOI: 10.36229/978-65-5866-047-7.CAP.06

Capítulo 7: A creche como um direito da mãe trabalhadora 56

Cláudia Vianna de Melo, Bárbara de Oliveira Gonçalves

DOI: 10.36229/978-65-5866-047-7.CAP.07

Capítulo 8: A importância da psicomotricidade na creche 65 


\section{SUMÁRIO}

Capítulo 9: A importância da Educação Infantil na psicomotricidade 73

Anaiara Lourenço da Silva, Priscilla Patrício de Holanda

DOI: 10.36229/978-65-5866-047-7.CAP.09

Capítulo 10: A importância da psicomotricidade no desenvolvimento cognitivo e corporal da criança: Uma visão reeducadora no contexto escolar 83

Vanderlea dos Santos Silva

DOI: 10.36229/978-65-5866-047-7.CAP.10

Capítulo 11: Cultura corporal e Educação Infantil na perspectiva histórico-cultural e histórico-crítica 90

Rafael Oliveira de Antonio

DOI: 10.36229/978-65-5866-047-7.CAP.11

Capítulo 12: A metacognição no ensino de língua portuguesa: Proposta de sequência didática a partir dos gêneros 94

Flaviana América Silva Dantas de Souza, Mirtes Ribeiro de Lira

DOI: 10.36229/978-65-5866-047-7.CAP.12

Capítulo 13: Valorizando a leitura como prática educativa dentro e fora da escola.. 103 Isabel Marth de Souza, Lauraci Dondé da Silva

DOI: 10.36229/978-65-5866-047-7.CAP.13

Capítulo 14: A pesquisa com os cotidianos e a trajetória de uma docente de inglês no Ensino Fundamental II 114

Cláudia Botelho Silva, Inês Barbosa de Oliveira

DOI: 10.36229/978-65-5866-047-7.CAP.14

Capítulo 15: A escola do campo e a valorização da identidade cultural dos educandos do ensino médio do assentamento 40/45 em Alcobaça - Bahia 123

Erivelton Santos Rodrigues, Yolanda Aparecida de Castro Almeida

DOI: 10.36229/978-65-5866-047-7.CAP.15 


\section{SUMÁRIO}

Capítulo 16: Pesquisas e o ensino de Ciências: Contribuições e dificuldades no Ensino Fundamental 130

Priscilla Cristina Georg, Creuzeli Aparecida Soares de Lima, Eva Bego, Jackson José Pagani

DOI: 10.36229/978-65-5866-047-7.CAP.16

Capítulo 17: Conhecendo aranha marrom e loxoscelismo: Prevenção, características dos acidentes e sintomas do envenenamento, um trabalho realizado com alunos do quarto ano do Ensino Fundamental

Mariana Luiza Claudino Mataruna, Guilherme Ferreira dos Santos, Silvio Sanches Veiga, Ana Carolina Martins Wille, Cristina Lúcia Sant'Ana Costa Ayub

DOI: 10.36229/978-65-5866-047-7.CAP.17

Capítulo 18: Uma abordagem sobre a Ecologia e Biologia da aranha marrom para o quarto ano do Ensino Fundamental em escola da Rede Pública Municipal de Ponta Grossa, PR

Caroline Amanda da Silva, Pamela Renata Oliveira Pontarolo, Bruno Abel Resende Silva, Ana Carolina Martins Wille, Cristina Lúcia Sant'Ana Costa Ayub

DOI: $10.36229 / 978-65-5866-047-7 . C A P .18$

Capítulo 19: Arboviroses como tema norteador de Educação Ambiental e Sustentabilidade na Educação Básica.

Rogério Ferreira da Silva, Cleyton da Silva Maciel, Ana Beatriz dos Santos Araújo

DOI: 10.36229/978-65-5866-047-7.CAP.19

Capítulo 20: Uso do Stop Motion como sensibilizadora no estudo da Educação Ambiental

Viviane Marques Sousa e Silva, Leticia Sousa dos Reis

DOI: 10.36229/978-65-5866-047-7.CAP.20

Capítulo 21: As contribuições das atividades lúdicas no ensino da Educação Ambiental: Um relato de experiência 156

Danilo Ramos Cavalcanti; Marcos de Figueiredo Andrade; Emanuella Barros de Souza Oliveira Alvares; Carlos Eduardo Gomes de Barros; Patrícia Mariana Vasco de Góz

DOI: $10.36229 / 978-65-5866-047-7 . C A P .21$ 


\section{SUMÁRIO}

Capítulo 22: Educação ambiental: Um relato de experiência no contexto da educação religiosa. 162

Ana Cristina Xavier Leandro de Oliveira, Maria Cristina Leandro de Oliveira Neves Ferreira, Carlos André Lucena da Cruz

DOI: $10.36229 / 978-65-5866-047-7 . C A P .22$

Capítulo 23: Conhecendo a percepção ambiental de estudantes do Ensino Fundamental II, através de desenhos em turmas de $8^{\circ}$ e $9^{\circ}$ anos.. 166 Ana Katarina Nascimento de Azevedo, Maria de Fátima Camarotti

DOI: $10.36229 / 978-65-5866-047-7 . C A P .23$

Capítulo 24: Ilha Interdisciplinar de Racionalidade em torno da sustentabilidade como alternativa na preservação do planeta. 174

Tatiane Evangelista Zils, Ana Paula Magagnin Pryvara, Danislei Bertoni, Awdry Feisser Miquelin, Igor de Paiva Affonso

DOI: $10.36229 / 978-65-5866-047-7 . C A P .24$

Autores: 


\section{Capítulo 1}

\section{Família e escola: Desafios e perspectivas para a gestão escolar}

\section{Danieli Martins Ambrós \\ Maritiele de Araújo Borges \\ Juliane Marschall Morgenstern}

Resumo: Esse trabalho contém informações referentes à prática do Estágio I- Gestão Escolar, realizado em uma Escola Municipal na cidade de Santa Maria- RS, onde relataremos a prática pedagógica realizada, acreditando que seja necessário resgatar os caminhos de formação enquanto futuras professoras.

Sabemos que seria um grande desafio resgatar questões pertinentes na gestão da escola, quer em termos de intervenção ou de apoio psicoeducacional, encaramos este estágio como um aprendizado, pois trabalhamos os conhecimentos adquiridos em sala de aula, e também estudamos como trabalhar o sistema educacional no sentido de Documentos Legais.

Entendemos que o sistema educacional é bem amplo e as vezes complicado. Todavia as ações que praticamos no Estágio Supervisionado de Gestão foram importantes para melhoria da relação família e escola. Também compreendemos que foi importante abordarmos os aspectos: interação, autoestima, disciplina, autonomia, esforço, frustações e prioridade para poder ter uma excelente interação entre os alunos, e igualmente ter uma melhoria da relação familiar em casa, principalmente na interação entre pais e filhos.

Palavras-chave: Interação; Autoestima; Frustações e Prioridade. 


\section{INTRODUÇÃO}

A Escola Municipal de Ensino Fundamental Duque de Caxias, fundada em 1920 com o nome de "Escola do Ipê", localizada na rua Francisco Lameira- no 555, no bairro Duque de Caxias, Santa Maria/RS. Sua Diretora Geral é a Silvia Beatriz Borges da Silva. Essa instituição de ensino tem como clientela uma população de nível sócio econômico médio e baixo. Os alunos provêm vilas e de locais distantes da escola.

Sua infra- estrutura física é composta por 14 salas de aula. A escola oferece Educação Infantil, atendendo crianças a partir dos quatro e cinco anos de idade, Ensino Fundamental com turmas do primeiro ano ao nono ano, nos períodos da manhã e tarde como também, no turno da noite a Educação de Jovens e Adultos, a EJA que, corresponde em duas etapas: etapa 3 (6o e 7음 ano), etapa 4 ( $8^{\circ}$ e $9^{\circ}$ ano).

A escola dispõe de biblioteca, Sala dos Professores, Secretaria, Sala de Direção, Quadra de Esportes, Sala da Coordenação Pedagógica, Sala da SOE, Sala de Recursos Multifuncionais e Atendimento Especializado, Salão de Reuniões e Audiovisual, Sala de Informática, Conselho Escolar, a chamada APPFA (Associação de Pais, Professores, Funcionários e Alunos). ${ }^{1}$

A instituição de ensino conta atualmente com mais ou menos 570 alunos, 50 professores e 6 funcionários. Uma das preocupações da escola são os índices de reprovação, os quais são maiores nos anos finais, do quinto ao nono ano. Por esse motivo há alguns fatores que vêm interferindo no processo de aprendizagem desses alunos como: desinteresse por parte dos alunos, metodologia inadequada do professor. Contudo, a instituição de ensino tem um grupo de professores que realiza trabalho multidisciplinar o qual, auxilia a suprir esses fatores que prejudicam o ensino.

Fator importante que a escola propõe e que de acordo com a sua filosofia institucional temos o seguinte:

A escola, entendemos, a sua função social, busca pensar sobre o seu "fazer pedagógico" na viabilização e concretização de seus objetivos [...]. Visa a propiciar um ensino adequado à realidade com igualdade de condições para o acesso e permanência na escola; liberdade de aprender, ensinar, pesquisar e valorização da experiência pessoal e coletiva, respeitar o pluralismo de ideias e concepções pedagógicas, a liberdade; apreço a tolerância através da gestão democrática. (PROJETO POLÍTCO PEDAGÓGICO, 2014, p.8)

Por isso, a Instituição de Ensino procura ações que influenciem positivamente a aprendizagem de todos os alunos. Tendo uma escola que busque lecionar de uma maneira adequada para o coletivo, como na própria citação diz, que tenha "liberdade de aprender, ensinar, pesquisar e valorização da experiência pessoal e coletiva..."

Por fim, será realizado nessa escola o Estágio Supervisionado de Gestão por duas Acadêmicas do Curso de Pedagogia na Universidade Franciscana, nos turnos manhã e noite, o período de execução será de agosto a novembro de 2018.

\section{JUSTIFICATIVA:}

A partir das observações dentro da sala de aula e com as sugestões da diretoria, nas quais, nos foi relatado o seguinte: pouca participação dos pais na escola. Por esse motivo, elaboramos um projeto para a escola que pudesse abranger os pontos que visualizamos que seriam interessantes abordarmos no Estágio Supervisionado de Gestão.

Assim sendo, pode-se compreender que a escola precisava que fosse argumentado algumas questões essenciais consequentemente, escolhemos o tema: Relação família e escola e como rede temática: autonomia, disciplina, autoestima, prioridade, esforço, frustações, problemas e integração pais, filhos e escola.

Com todos esses assuntos que, anteriormente foram pontuados, o nosso estágio contempla em auxiliar a escola tanto no requisito resolução de assuntos pertinentes como: Relação família e escola e como rede

\footnotetext{
${ }^{1}$ Trecho retirado no Projeto Político Pedagógico da Escola Municipal de Ensino Fundamental Duque de Caxias.
} 
temática: autonomia, disciplina, autoestima, prioridade, esforço, frustações, problemas e integração pais, filhos e escola. E igualmente em relação a estrutura pedagógica da instituição de ensino como, os membros que fazem parte dela, como: alunos, pais, professores, equipe da administração, equipe da direção, coordenações entre outras.

Estabelecendo um parecer acerca de todas essas questões abordadas afirma-se que, o Estágio de Gestão foi realizado para apreciar as questões mais indispensáveis que foram observadas na escola. Dessa forma, foi escolhido esse tema e esses subtemas para ajudar da melhor maneira possível a instituição que estávamos realizando o estágio.

\section{FUNDAMENTAÇÃO TEÓRICA:}

Gestão não é apenas o ato administrativo, elaboração de políticas públicas da instituição de ensino. Em nosso Estágio Supervisionado de Gestão vamos elaborar uma prática que aborde necessidades da escola, abrangendo os alunos, pais e toda equipe de professores. Por isso, para Luck(2014) gestão educacional é uma ação vinculada a parte administrativa, estrutural, um sistema como um todo de uma instituição.

Igualmente nossa função dentro desse espaço social é contribuir ativamente, auxiliando em seus pontos relevantes que visualizamos que seriam interessantes abordarmos no Estágio de Gestão. Dessa forma Gohn (2006, p.29) afirma que:

Na educação formal estes espaços são os do território das escolas, são instituições regulamentadas por lei, certificadoras, organizadas segundo diretrizes nacionais. [...] A educação formal pressupõe ambientes normatizados, com regras e padrões comportamentais definidos previamente [...] outros objetivos destacam-se os relativos ao ensino e aprendizagem de conteúdos historicamente sistematizados, normatizados por leis, dentre os quais destacam-se o de formar o indivíduo como um cidadão ativo, desenvolver habilidades e competências várias, desenvolver a criatividade, percepção, motricidade etc.

Em relação a esse dizer de Gonh pensa-se que, a educação formal abrange as relações sociais, um marco que será abordado nesse estágio. Esperamos que, possamos desenvolver um trabalho promissor, que contribua positivamente para essa Instituição de Ensino. Ao longo desse projeto será relatado nossos objetivos como também, nossas vivências desenvolvidas nesse espaço social.

\section{OBJETIVOS}

\subsection{OBJETIVO GERAL:}

Promover espaços de participação da família na escola para fortalecer o vínculo entre família e escola.

\subsection{OBJETIVOS ESPECÍFICOS:}

Instigar a contribuição dos pais na escola a fim de auxiliar na gestão da mesma;

Estudar formas de vinculação entre a família e escola proporcionando um melhor relacionamento entre ambos.

\section{DESENVOLVIMENTO:}

O Estágio de Gestão será realizado na escola Duque de Caxias, na cidade de Santa Maria- RS, no turno da manhã. As atividades serão executadas nas segundas-feiras e as vezes nas quintas-feiras. Foi combinado com a diretora Silvia, que vamos elaborar duas atividades com os pais dos alunos. No primeiro encontro vamos fazer uma roda de conversa com os pais, escutando-os, ver as suas demandas que eles têm em relação aos seus filhos. Nesse encontro vamos passar dois vídeos de Mário Sérgio Cortella e realizaremos uma dinâmica.

No segundo encontro, vamos desenvolver uma palestra a partir das reivindicações dos pais e finalizaremos com uma dinâmica realizando assim, dois encontros na Instituição de Ensino com os pais. Durante todo o desenvolvimento do projeto, este deve apresentar atividades desafiadoras e integradoras com a área de abrangência de estágio. Primeiro vídeo: Família e Escola- Mário Sérgio Cortella; segundo vídeo: não seja refém do seu filho- Mário Sérgio Cortella. 


\subsection{PRÁTICAS DESENVOLVIDAS NA ESCOLA:}

Na noite, do dia 27 de setembro, ocorreu uma reunião, ou melhor dizendo, uma roda de conversa com os pais na Escola Municipal de Ensino Fundamental Duque de Caxias. Foi realizado no auditório na escola, previsto para começar as 19h30, porém como havia poucos pais decidimos esperar até as 19h45.

Mesmo assim, para essa roda de conversa apenas apareceram dois pais (mãe e um tio) e dois alunos sendo que, um deles foi convidada ali na hora pela diretora, pois não sabia desse encontro. Foi uma noite muito prazerosa, com bastante diálogo, com muitas trocas de ideias e opiniões entre nós, estagiárias juntamente com os pais e educandos.

Perguntamos a eles o que acharam dos dois vídeos de Mario Sergio Cotella, e eles gostaram muito. 0 primeiro vídeo discutia sobre "pais e escola' e o segundo vídeo "não seja refém de seu filho". Os dois vídeos relataram temas muito relevantes como: disciplina, frustações, autoridade, prioridade, autonomia, das quais foram muito debatidos durante a roda de conversa.

Questões que, para esses adultos que compareceram no encontro acharam fundamentais a instituição de ensino abordar pois são temas importantíssimo para nossa sociedade de agora. Sobre a conversa podemos concluir que, foram poucos participantes mas com muita qualidade, pode-se dizer que, aprendemos muito e já estamos planejando o próximo encontro.

No segundo momento desse encontro, realizamos uma dinâmica chamada "como enxergamos o outro" da qual tivemos que modificar devido ao número de participantes na sala. A dinâmica era assim primeiramente, entregamos para cada uma metade de uma folha de ofício, nele tinham que escrever pontos positivos e negativos de outra pessoa.

Como estavam nesse encontro mãe e filho e o outro era tio e sobrinho, cada um deles tinha que escrever um do outro. Depois que escreveram cada um conversava com o outro, uma dupla de cada vez, sobre esses pontos positivos e negativos que enxergavam no outro propondo assim, ideias para melhorar as relações deles dentro e fora de casa. Igualmente interferimos nessa dinâmica, os auxiliando a ter ideias para melhorar a relação entre eles.

Mesmo que a vivencia desenvolvida na escola tenha tido pouca participação, foi um encontro muito proveitoso. Buscou-se interagir com os pais e alunos na intenção de entende-los, de ter um momento de expressar suas opiniões no intuito deles sentirem parte integrante da escola.

Pelo motivo da pouca participação dos pais não foi realizado um segundo encontro com os pais por esse fato percebemos que, seria importante mudarmos nossa estratégia. Então, a partir da reunião que tivemos com a diretora e coordenadora no período da noite, consideramos prudente direcionamos nossa abordagem com os alunos.

Nesse caso, entendemos que as turmas do sétimo ano seriam o grupo de alunos que nesse momento estavam precisando da nosso auxilio já que, nossa função lá dentro da Instituição é contribuir ativamente nesse espaço social.

Inicialmente para realizarmos a segunda etapa do estágio, executamos seis observações, três em cada turma do sétimo ano e também conversamos com alguns professores. A partir disso, percebeu-se que devíamos trabalhar autoestima, prioridade, frustações, pontos fundamentais para auxiliá-los em melhor o desempenho em sala de aula.

Já que, a equipe de professores nos relataram que as duas turmas de sétimo ano, haviam alguns alunos que não estavam com notas muito boas e que poderiam haver muitas reprovações nesses duas turmas. Por esse motivo, buscou-se realizar uma dinâmica que alcançasse desenvolver esses pontos, das quais, consideramos importantes a serem abordados no desenvolvimento dessa prática com as duas turmas de sétimo ano.

A dinâmica realizada com eles chama-se: troca de um segredo, da qual, tem como objetivo fortalecer a amizade e a união do grupo, encontrar soluções para os problemas, dar a oportunidade para que os participantes exponham um problema sem se identificar. Foi utilizado uma folha de papel branca para cada participante e a duração da dinâmica é de 45 minutos porém, tanto em uma turma como na outra levou mais de uma hora a execução.

O desenvolvimento dessa prática é reunir os participantes em uma roda, em um lugar tranquilo, distribuímos as folhas para cada participante. Em seguida, diga para cada um escrever um problema pessoal, uma dificuldade ou angustia que esteja afetando sua vida no momento. Diga que não há necessidade de se identificar, mas que todos precisam ser sinceros. 
Assim que todos terminarem de escrever sobre os seus problemas, peça para que todos dobrem a folha cuidadosamente e depositem o papel no recipiente, no caso utilizamos uma caixa de papelão. Misture todos os papeis e, em seguida, redistribua as folhas entre os participantes. Oriente o grupo a ler o conteúdo do papel recebido, sem fazer julgamento.

Proponha uma reflexão individual sobre o assunto e, em seguida, peça para que os participantes falem sobre o problema recebido e apresente uma solução ou conselho. É essencial que todos sejam sinceros, encarando o problema como se fosse seu. Os demais participantes não devem opinar ou fazer comentários entre si. Ao final, fale sobre como todas as pessoas passam por problemas ou dificuldades que, muitas vezes, são até parecidos entre si. Destaque a importância de se abrir com outras pessoas, explicando como pode ser possível encontrar a solução para um problema a partir do ponto de vista de uma outra pessoa que não está envolvida diretamente com a situação.

Essa prática acima como já havíamos comentado anteriormente, foi executado nas turmas do sétimo ano. A primeira turma que concretizamos a dinâmica foi a turma do sétimo ano amarelo, na qual, reparamos que a turma no começo da prática estavam bem concentrados. Nesse grupo, observamos que expressaram problemas bastante sério, e que consideramos importante a escola ficar atenta.

Igualmente, no decorrer da dinâmica constatamos que nessa turma teve dois alunos destaque, em que, auxiliavam os seus companheiros de sala a solucionar o problema dos outros camaradas. No final, verificamos que a turma tem uma ótima interação uns com os outros.

Já na turma do sétimo ano verde, percebemos que também abordaram vários assuntos pertinentes. Nesse grupo, observou-se que, igual a outra turma, há alunos destaques, que ajudaram os outros colegas a solucionar o problema.

Sendo assim, constatou-se que essa dinâmica foi indispensável para essas turmas e que, esperamos que possamos ter contribuído positivamente de alguma forma para que, eles possam melhorar no processo de aprendizagem como também, nas relações dentro da escola ou dentro de suas casas.

E para demonstrar os trabalhos realizados na escola trago algumas fotos, como:

FIGURA 1:

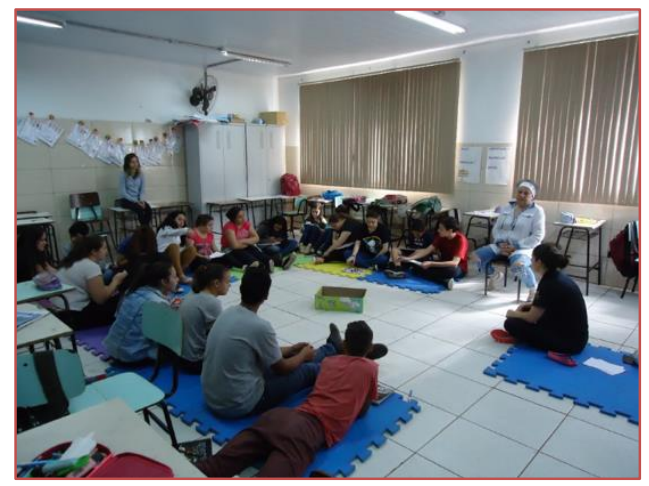

FIGURA 2:

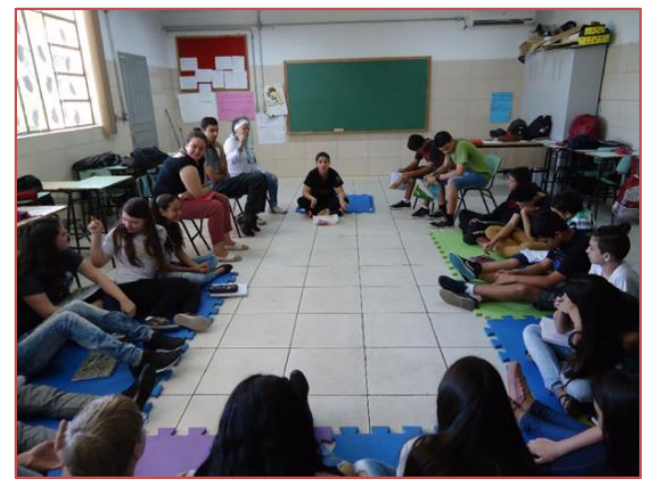




\section{FIGURA 3:}

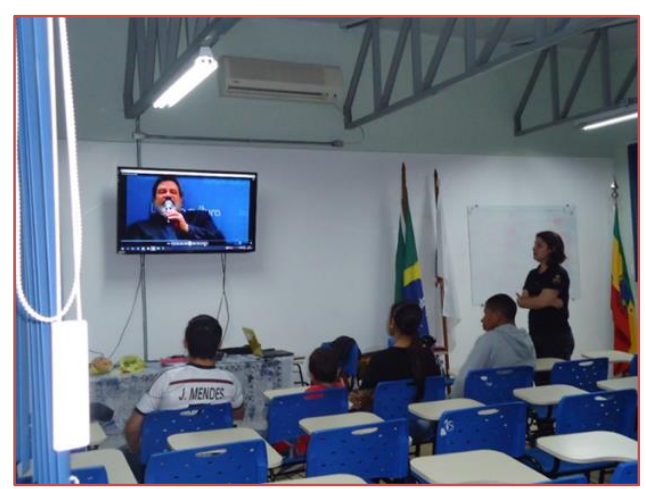

\section{CRONOGRAMA DE ATIVIDADES}

\begin{tabular}{|c|c|}
\hline ATIVIDADES & PERÍODO \\
\hline $\begin{array}{l}\text { Primeiro contato com o campo de estágio I no período da noite. Foi realizado com a } \\
\text { diretora da Instituição de Ensino. }\end{array}$ & 29 de Agosto/2018 \\
\hline $\begin{array}{l}\text { Manhã em que nos reunimos com a diretora da escola para conversarmos sobre os } \\
\text { pontos relevantes que iríamos abordar em nosso estágio. }\end{array}$ & 5 de setembro/2018 \\
\hline Manhã em nos reunimos coma diretora para coleta alguns dados sobre a escola. & 10 de setembro/2018 \\
\hline $\begin{array}{l}\text { Manhã em que comparecemos na Instituição de Ensino para começarmos a construir o } \\
\text { projeto de estágio. }\end{array}$ & 17 de setembro/2018 \\
\hline $\begin{array}{l}\text { Manhã em que realizamos uma reunião com a direção da escola para conversarmos } \\
\text { sobre o que havíamos pensado para pormos em pratica na escola. }\end{array}$ & 24 de setembro/2018 \\
\hline $\begin{array}{l}\text { Realizamos no período da manhã, dentro da escola, o roteiro do primeiro encontro com } \\
\text { os pais. E depois entregamos nas salas de aula o convite. }\end{array}$ & 25 de setembro/2018 \\
\hline $\begin{array}{l}\text { Noite em que executamos o primeiro encontro com os pais, na qual, foi realizado na sala } \\
\text { de vídeo da escola. }\end{array}$ & 27 de setembro/2018 \\
\hline $\begin{array}{l}\text { Reunião com a direção para redirecionarmos a nova prática que vamos exercer na } \\
\text { escola. }\end{array}$ & 10 de outubro/2018 \\
\hline $\begin{array}{l}\text { Nessa manhã nós deslocamos para sala de aula do sétimo ano amarelo. Ficamos } \\
\text { observando os dois primeiros períodos, das quais, haviam aula de artes }\end{array}$ & 16 de outubro/2018 \\
\hline $\begin{array}{l}\text { Nessa manhã nós deslocamos para sala de aula do sétimo ano amarelo. Ficamos } \\
\text { observando os dois últimos períodos. Nas aulas de ciência no primeiro período e na } \\
\text { aula de matemática no segundo período. }\end{array}$ & 17 de outubro/2018 \\
\hline $\begin{array}{l}\text { Manhã em que sentamos juntamente com a coordenadora da manhã para visualizarmos } \\
\text { e coletarmos os dados no Projeto Político Pedagógico da escola. }\end{array}$ & 22 de outubro/2018 \\
\hline $\begin{array}{l}\text { Nos dois primeiros períodos da manhã observamos a turma do sétimo ano verde, das } \\
\text { quais, havia aula de geografia. }\end{array}$ & 23 de outubro/2018 \\
\hline $\begin{array}{l}\text { Nos dois primeiros períodos da manhã fomos observar a turma do sétimo ano amarelo. } \\
\text { Ficamos nas aulas primeiramente de matemática e no segundo período de português. }\end{array}$ & 24 de outubro/ 2018 \\
\hline $\begin{array}{l}\text { Última observações realizadas nas salas de aula do sétimo ano. Nos dois primeiros } \\
\text { períodos presenciamos na turma do sétimo ano verde, nas aulas de biologia e depois } \\
\text { inglês. Após o recreio fomos para a turma do sétimo ano amarelo, analisamos também } \\
\text { nas aulas de ciência e inglês no último período. }\end{array}$ & 29 de outubro/ 2018 \\
\hline $\begin{array}{l}\text { Manhã em que executamos a dinâmica. Primeiramente concretizamos a prática no } \\
\text { sétimo ano amarelo. Depois do recreio efetuamos no sétimo ano verde. }\end{array}$ & 30 de outubro/ 2018 \\
\hline $\begin{array}{l}\text { Realizaremos a atividade integradora. Realizamos um agradecimento para a diretora da } \\
\text { escola. Entregamos um mimo a ela. }\end{array}$ & 22 de novembro/2018 \\
\hline
\end{tabular}




\section{RESULTADOS E DISCUSSÕES}

A realização dos encontros com os pais/responsáveis e com os alunos foi importante para atingir os objetivos propostos pelo projeto de estágio. As rodas de conversa instigaram o diálogo e o compartilhamento de vivências entre os pais e também foi de grande relevância para que os alunos pudessem ter suas reivindicações e visão do contexto escolar considerado. Assim, foi indispensável realizar a dinâmica com os alunos e esperamos ter contribuído positivamente para que eles se sentissem ativos no processo de aprendizagem e pertencentes no que diz respeito às relações estabelecidas dentro e fora da escola. Também consideramos que abordar a temática da autoestima, da disciplina e da autonomia levou a reflexão dos alunos em seu dia-a-dia fazendo-os se perceberem como estudantes que tem responsabilidade sobre o próprio aprendizado. Nessa direção, buscamos promover a autonomia dos estudantes, o que também levou a melhoria da comunicação e interação entre eles.

A experiência foi relatada pelos alunos como positiva e motivadora levando para a busca de apoio entre colegas, no ambiente escolar e também em casa, com os pais ou responsáveis. Também importa considerar que, de acordo com os relatos da equipe gestora e de alguns familiares e alunos, as ações realizadas na escola foram de grande importância para o aprimoramento do diálogo e ampliação da relação entre escola e família. Tais depoimentos, posteriores a nossa intervenção na escola, foram importantes para percebermos que as rodas de conversa podem se tornar uma ação que aproxima os pais/responsáveis e a escola, fazendo com que a interação entre os diferentes setores da comunidade escolar se fortalecesse.

Também compreendemos ser de grande relevância a adoção de uma perspectiva de gestão democrática pela escola e a compreensão dessa perspectiva pela equipe gestora, pois assim foi possível buscar meios para estimular a participação dos pais no contexto escolar, ampliando as formas de representação e de ações da família na escola (LIBÂNEO, OLIVEIRA e TOSCHI, 2012; LUCK, 2014).

\section{CONCLUSÃO}

A realização do estágio em Gestão escolar trouxe muitas aprendizagens para a nossa formação profissional. Por meio do estágio, compreendemos qual é a função da gestão escolar e como se dá o trabalho dos gestores no dia-a-dia de uma escola de ensino fundamental de Santa Maria, RS. Ao longo do estágio percebemos os desafios enfrentados nos diferentes setores da escola e reconhecemos a necessidade de que os pais/responsáveis pelos alunos participem de forma ativa nas ações desenvolvidas no meio escolar, para que os objetivos educacionais sejam alcançados de forma efetiva.

Nesse cenário, a gestão precisa se democratizar cada vez mais para que todos os integrantes da comunidade escolar, tanto pais e familiares quanto professores e funcionários, tenham voz ativa e possam colaborar com o funcionamento do ambiente escolar e aprendizagem dos alunos. Todos esses grupos fazem parte da vida escolar e precisam ser responsabilizados pelo funcionamento da escola, tendo em vista que na perspectiva de uma gestão democrática, todos integram a gestão, todos são gestores e não apenas a equipe diretiva. Assim, o que acontece no cenário escolar, bem como as decisões e direcionamentos da escola devem ser debatidos e assumidos por todos aqueles que fazem parte de sua comunidade, para viabilizar uma gestão que seja democrática em suas ações e não apenas nos registros escolares.

\section{REFERÊNCIAS}

[1] ESCOLA MUNICIPAL DE ENSINO FUNDAMENTAL DUQUE DE CAXIAS. Projeto Político Pedagógico- PPP. Santa Maria, p. 1- 173, 2016.

[2] GOHN, Maria da Glória. Educação não-formal, participação da sociedade civil e estruturas colegiadas nas escolas. Avaliação e Políticas Públicas em Educação - SciELO Brasil, Rio de Janeiro, v.14, n.50, p. 27-38, jan./mar. 2006. Disponível em: < http://www.scielo.br/pdf/ensaio/v14n50/30405/ >. Acessado em: Novembro de 2018.

[3] LIBÂNEO, José Carlos; OLIVEIRA, João Ferreira de; TOSCHI, Mirza Seabra. Educação Escolar: Políticas, estrutura e organização. 10ำ ed. São Paulo: Cortez, 2012.

[4] LUCK, Heloísa. Gestão Educacional: Um a questão paradigmática. 11. Ed. Petrópolis, RJ: Vozes, 2014. 


\section{Capítulo 2}

A gestão em sala de aula na experiência de estágio curricular nos anos iniciais do Ensino Fundamental

\section{Wilvania Carvalho de Souza Paiva}

\section{Eunice Maria da Silva}

Resumo: Trata-se de um relato de experiências vivenciadas no Estágio Curricular do Curso de Pedagogia, desenvolvido nos anos Iniciais do Ensino Fundamental. Focaliza aspectos da gestão da sala de aula a partir da observação direta, escuta sensível e mediações pedagógicas em espaço escolar da rede pública de ensino do município de Paulo Afonso - BA. Furlani (2000); De Certeau (2005); Freire (1983-1996); Gomes (2009) foram as principais referências na construção deste trabalho. Conclui-se que o tempo de estágio curricular supervisionado constituiu-se experiência relevante na formação dos profissionais em educação, sobretudo no que diz respeito à gestão da sala de aula, às tomadas de decisões com vistas à criação de ambiente e situações de aprendizagem significativas.

Palavras-chave: Estágio Curricular. Gestão em sala de aula. Prática docente. 


\section{INTRODUÇÃO}

O Estágio Curricular no Curso de Pedagogia da Universidade do Estado da Bahia (UNEB) é desenvolvido no intervalo letivo do V ao VII semestre, dentro dos componentes curriculares de Pesquisa e Estágio I, II e III (PEI, PEII, PEIII). Em PEI, iniciam-se processos de investigação e conhecimento da realidade para a elaboração e execução de projetos de intervenção em contextos Não Escolares. Por sua vez, em PEII, as investigações e intervenções tomam como objeto a realidade do campo da Educação Infantil. Por fim, PEIII focaliza a organização do trabalho pedagógico e projetos de intervenção nos anos iniciais do Ensino Fundamental.

Assim sendo, deve-se compreender que o Estágio Curricular é um percurso obrigatório do Curso de Pedagogia que norteia os saberes teóricos e práticos, que deve subsidiar a formação docente no exercício das práticas pedagógicas, considerando o contexto social, cultural, econômico e real dos sujeitos envolvidos. Portanto, é de caráter formativo, sendo uma atividade a ser integralizada pelos estudantes, caracterizada como um ato educativo orientado e supervisionado (UNEB/CONSEPE № 2.016/2019).

Partindo desse contexto, o presente trabalho tem como objetivo descrever um conjunto de experiências, com ênfase na gestão em sala de aula, que incluem tomadas de decisões e organização de situações e ambientes de aprendizagem de estudantes dos anos iniciais do Ensino Fundamental, evidenciando, ainda, a importância da experiência de Estágio Curricular na formação acadêmica para a docência.

O interesse pelo tema gestão em sala de aula emerge das discussões, ao longo da graduação, acerca de pelo menos três de suas grandes dimensões: o trabalho com o conhecimento, a organização da coletividade e o relacionamento interpessoal. Como um prolongamento da gestão escolar, a gestão em sala de aula pressupõe a criação de um ambiente, no qual, possam ser produzidas, manifestadas e experimentadas ações comprometidas com os interesses coletivos.

Nessa direção, vários estudos, a exemplo de Freire (1983-1996); Furlani (1988-2000); e Gomes (2009) apontam para a complexidade dos fazeres docentes que colocam o professor frente ao desafio de gerir situações didático-pedagógicas que incluem planejamento e execução de atividades, administração de tempos e modos de aprender, gerenciamento de interações e conflitos relacionais, além da gestão dos conteúdos de ensinagem 2 e dos feedbacks dos processos avaliativos.

\section{ORIENTAÇÕES METODOLÓGICAS}

As experiências relatadas neste trabalho fundamentam-se nas atividades realizadas no componente curricular de Pesquisa e Estágio III, isto é, no contexto educativo dos anos iniciais do Ensino Fundamental, perfazendo um total de 100 horas de estágio, distribuídas entre as etapas de observação, coparticipação e regência. Desse modo, no período da observação ocorreram os primeiros contatos da estagiária com as professoras e estudantes para apreender e acompanhar a dinâmica do grupo sem a participação efetiva nas atividades didáticas; na coparticipação foi possível realizar diversas atividades com os estudantes em sala, em regime de colaboração entre a estagiária e as docentes; a regência caracteriza-se como momento crucial, sendo requerido que a estagiária coloque em prática os saberes da docência que foram construídos ao longo do percurso acadêmico, sobretudo no que diz respeito ao gerenciamento, articulação e desenvolvimento das ações pedagógicas planejadas, a partir das demandas de aprendizagem que emergem da realidade dos estudantes.

O local do Estágio Curricular foi a Escola Casa da Criança 01, situada no Município de Paulo Afonso - BA, que atende alunos de baixo poder aquisitivo, inclusive, de municípios circunvizinhos. A escola selecionada integra a rede pública de ensino municipal, sendo este um dos critérios para a sua escolha, pois, conforme as orientações da Resolução UNEB/CONSEPE № 2.016/2019, os estágios devem ser realizados, prioritariamente, nas redes públicas, instituições e organizações da sociedade civil sem fins lucrativos.

Os principais sujeitos envolvidos nas experiências relatadas foram 39 alunos, regularmente matriculados no segundo e terceiro anos do Ensino Fundamental, quatro professoras e uma cuidadora. Vale dizer que alguns estudantes matriculados cumpriam medidas socioeducativas, sendo muito frequente a presença de viaturas policiais na instituição, sobretudo no período noturno, evidenciando certa tensão no cotidiano escolar.

\footnotetext{
${ }^{2}$ Termo adotado para significar uma situação de ensino da qual necessariamente decorra a aprendizagem, sendo a parceria entre professor e alunos, condição fundamental para o enfrentamento do conhecimento, necessário à formação do aluno (ANASTASIOU, 1998).
} 
Considerando que os estudos descritivos são amplamente usados na educação e nas ciências comportamentais, o objetivo primordial deste relato de experiência é a descrição de situações vivenciadas no Estágio Curricular, com foco na gestão em sala de aula. É oportuno salientar que o valor da natureza descritiva, assumida neste trabalho, baseia-se na premissa de que as situações podem ser enfrentadas e as práticas melhoradas por meio da observação objetiva e minuciosa, da análise e da descrição (MOREIRA \& CALEFFE, 2006).

\section{PRESSUPOSTOS TEÓRICOS E CONTEXTO DA GESTÃo EM SALA DE AULA NO ENSINO FUNDAMENTAL}

A discussão da gestão da sala de aula surge a partir da nova perspectiva pedagógica a do professor como gestor. Ela traz subsídios que envolvem teorias e práticas relacionadas à construção da ensinagem. Para tanto, esse novo olhar pedagógico evidencia o docente como mediador do conhecimento, trazendo também a responsabilidade de gerir todo o espaço sala de aula.

Nessa perspectiva, os anos escolares iniciais constituem-se mão de via dupla: o professor proporciona um ambiente profícuo e a escola como um todo, dar suporte para que este ambiente alcance os espaços para além da sala de aula, gerando nos alunos conhecimentos específicos e relevantes para o seu nível intelectual. No entanto, o professor precisa conhecer a realidade dos seus alunos e levá-los a buscar o aperfeiçoamento de tudo o que lhe está sendo apresentado. Em outras palavras, o docente precisa ser gestor do processo de conhecer.

Sendo assim, a gestão do conhecimento, ou seja, dos saberes docentes fala de uma pedagogia metódica (FREIRE, 1996), que exige do professor uma criticidade objetiva dos fatores que emergem a construção dos múltiplos desenvolvimentos do ensino-aprendizagem.

Portanto, para promover a gestão do conhecimento nos anos iniciais, o professor precisa estar à frente do seu tempo, sempre reinventando estratégias de ensinagem, resignificando os conceitos de alfabetização e letramento. Sobre o conceito de alfabetização pode-se dizer, de modo abrangente, que se trata do processo de aprendizagem de representação de sons da fala, mais precisamente, é como transformamos o som da fala "fonemas" em letras ou "grafemas". Já o processo de letramento caracteriza-se pelo desenvolvimento da habilidade de uso da leitura e da escrita.

Para Segundo Soares (2004, p.25), alfabetização e letramento

não são processos independentes, mas interdependentes, e indissociáveis: a alfabetização se desenvolve no contexto de e por meio de práticas sociais de leitura e de escrita, isto é, através de atividades de letramento, e este, por sua vez, só pode desenvolver-se no contexto da e por meio da aprendizagem das relações fonemagrafema, isto é, em dependência da alfabetização.

Considerando o que já foi exposto neste texto, para além de ensinar o estudante a ler e a escrever, uma das principais competências do professor gestor nos anos iniciais do Ensino Fundamental é estimular o desejo de continuar lendo, ser um leitor, interpretar suas próprias histórias, números, natureza, espaços geográficos, dentre outros conceitos, e a organização do ambiente de aprendizagem que são cruciais para um processo de alfabetização satisfatório.

Voltando o olhar para a prática docente na escola onde foi realizado o estágio, durante as observações na turma do $3^{\circ}$ ano, foi notório perceber que as professoras não estavam muito interessadas em gerenciar o tempo e o espaço da sala de aula. Sempre cansadas, relatavam em suas falas que estava muito difícil ser educador do século XXI; que os alunos já não eram como os de antigamente. Todavia, percebia-se que não era somente a evolução dos alunos desse século, mas também a didática das docentes que permanecia a mesma de muitos anos atrás, ultrapassada para os estudantes do século XXI. Não pareciam motivadas e não apresentavam propostas intencionais de ensinagem.

Se compararmos os processos metodológicos ou didáticos das docentes com as teorias discutidas pelos autores de referência que defendem uma educação lúdica, mediadora e libertadora, temos um choque de realidade. Falar desses aspectos é evidenciar a necessidade de um conjunto de habilidades e aguçado senso de responsabilidade, indispensáveis para o enfrentamento dos desafios contemporâneos, da história dos sujeitos, dos tempos de aprendizagem, do espaço escolar, da relação professor-aluno, aluno-professor e conteúdo. Sem essa clareza de função, as professoras não conseguem gerenciar as demandas da sala de aula. 
Durante as observações foi possível notar que a metodologia utilizada pelas professoras era muito distante daquilo que elas apresentavam em seus planos de aula, evidenciando, desse modo, certa limitação no cumprimento das metas estabelecidas. As turmas em questão eram superlotadas e os alunos ofereciam muita resistência às exortações quanto ao barulho e recorrentes conflitos na relação com os colegas e realização das atividades. Inúmeras vezes as professoras precisavam da ajuda de terceiros, a exemplo da direção. Era fácil notar, também, que as professoras confundiam autoridade com autoritarismo, e essa confusão de entendimento prático dificultava ainda mais o relacionamento com os alunos, pois, o autoritarismo fala de repreensão, de poder central, onde somente o professor tem voz, estabelecendo dentro da sala de aula uma pedagogia da opressão (FREIRE, 1983). Entretanto, autoridade, fala de competência, respeito, conquista. Isso implica dizer que falar de autoridade docente é destacar a responsabilidade que o próprio professor tem em garantir o aperfeiçoamento no que se refere a sua formação, para que haja reconhecimento da sua faculdade técnica de ministrar, mediar e gerenciar os processos de ensino e aprendizagem em diferentes contextos educacionais. Portanto "a segurança que a autoridade docente se move implica [...] na sua competência profissional” (FREIRE, 1996, p.91). E falar de postura profissional, requer realmente que o professor compreenda que ele é o adulto da relação e que precisa gerenciar as situações conflituosas com maturidade.

Nesta concepção, o professor exerce a autoridade que lhe é atribuída para o desempenho dos papéis que facilitam um clima de negociação normal - isto é, com conflitos - dentro do qual o poder do aluno pode ser exercido de forma que haja influências mútuas (FURLANI, 2000, p.37).

Com isso, fica claro que a autoridade não se desassocia do ato de ensinar, pelo contrário, ela faz parte do "ser docente". Já o autoritarismo, pode até se enquadrar no militarismo, mas nunca em uma sala de aula.

Na sequência, voltando para as observações das turmas, a relação de respeito entre os alunos e os professores já estava fora do limite suportável. Não eram somente as professoras que se queixavam do comportamento dos alunos, mas, os alunos também reclamavam do modo como as docentes se portavam frente à classe. Nesse período de escuta, foi possível registrar a seguinte fala de um dos alunos: " $A$ professora A, é burra! Todo dia passa a mesma coisa".

Analisando a fala do aluno, pode-se chamar a atenção para pelo menos dois aspectos: o primeiro é que a professora citada já não gozava do respeito e admiração do aluno, o que tornava sem efeito qualquer tentativa em mantê-lo em sala de aula; e o segundo é que o aluno já estava cansado da estratégia metodológica demasiadamente repetitiva. É oportuno, também, falar que as professoras frequentemente se dirigiam aos alunos com palavras ofensivas. Em uma aula de matemática, a professora A se reportou ao aluno da seguinte forma: "você é burro! Tirou zero na prova, vai repetir de ano, vai ficar igual a sua família, você sabe que eu sei que sua família não presta e você vai ficar igual a eles". Essa fala provocou uma reação muito forte nos alunos, sendo rebatida com as seguintes falas: "preconceituosa! Eu amo minha família do jeito que ela é! Você que é burra!". Diante desses conflitos, fica bastante claro que a professora perdeu a autoridade do ser docente, perdeu a autoridade de gerir em sala de aula, de ser o adulto da relação, de cativar os alunos para aquilo que se proclama como pedagogia afetiva, acolhedora. 0 que se pode observar, também, é que a sala de aula se transformou em um ambiente de disputa de egos, ou seja, naquela situação se estabeleceu um duelo: quem ofende mais, a professora ou aluno?

0 trabalho pedagógico em sala de aula envolve o gerenciamento com pessoas com vistas a incentivar a expressão do melhor delas, provocar desejos de aprender a aprender, lidar com resistências, afastamentos e desinteresses. É muito interessante, também, ressaltar que as docentes iniciavam as aulas com alguns rituais religiosos, mas os estudantes se mostravam indiferentes e alguns se recusavam a participar daquele momento. Apesar das insatisfações declaradas, as professoras eram irredutíveis quanto à obrigação de todos os alunos, sem exceção, rezarem. "[...] historicamente o autoritarismo é facilmente associado a um contexto educacional, seja a educação religiosa ou militar que foi adotada, por muito tempo, no trabalho pedagógico" (FURLANI, 2000, p. 34).

Logo, fica fácil perceber a urgente necessidade de entender o lugar da autoridade no contexto educacional, sobretudo no que diz respeito aos processos e procedimentos das relações que envolvem o educador e o educando. Portanto, quando a autoridade encontra o lugar devido nessa relação pedagógica, o professor consegue desempenhar com segurança a sua função de mediador do processo de ensino/aprendizagem que o encaminha ao desenvolvimento de procedimentos democráticos nas interações didático-

\footnotetext{
${ }^{3}$ As falas dos sujeitos envolvidos neste trabalho foram escritas no modo itálico para se diferenciarem das citações dos autores de referência.
} 
pedagógicas, que, por consequência, reforçam o comprometimento e a responsabilidade que o professor tem ao gerir o espaço sala de aula, requerendo maturidade e competência profissional.

\section{ENTRE LIMITES E POSSIBILIDADES NA GESTÃO EM SALA DE AULA}

A agressividade nas relações que ocorrem nos espaços educativos tem se tornado lugar comum, vez que as crianças e os adolescentes têm enfrentado uma série de transformações físicas e psicológicas e que muitas vezes estão relacionadas a modernidade deste século. Essas transformações interferem diretamente no comportamento frente às situações vivenciadas por elas, seja financeira, familiar ou social.

Pode-se dizer, então, que a escola é a entrada para a sociedade, onde as crianças e jovens encontram seus primeiros pares, desenvolvem relações emocionais e afetivas, antipatias, competições, entre outros sentimentos, desencadeando, com frequência, comportamentos agressivos frente a situações, nas quais, não conseguem lidar com a baixa resistência a frustração; costumeiramente agridem, verbalmente e/ou fisicamente, professores e colegas de classe. Isso acontece, também, porque as crianças entram cada vez mais cedo nas instituições escolares e, por sua vez, constroem suas personalidades a partir das visões e experiências com outros indivíduos; passam mais tempo com os colegas da escola e se distanciam cada vez mais do contexto familiar.

Para Tiba (1996, p.79), "a educação escapou ao controle da família porque, desde pequena a criança já recebe influências da escola, dos amigos, da televisão e da internet". Esse cenário é propício para o aumento da agressividade e esta interfere diretamente na prática pedagógica das professoras, uma vez que desestabiliza a rotina da sala de aula e afronta as regras escolares. "[...] a agressividade humana surge associada à [...] capacidade ou prejuízo ou destruições, materiais ou morais, a outra pessoa ou a si mesmo [...]" (ABREU, 1998, p.133).

Ainda durante a observação, em uma das aulas de Língua Português, dois alunos começaram a discutir. Estavam muito hostis e irredutíveis. A professora, por sua vez, olhou para a estagiária e disse que não era pra fazer nada, pois, não se tratava apenas de um enfretamento corporal, que os alunos eram bastante agressivos e que não adiantariam tentativas de intervenções. Após alguns minutos, duas alunas também partiram para as agressões verbais, e a professora insistiu novamente dizendo que era para a estagiária ignorar aquela situação.

Diante disso, foi possível identificar o contexto complexo que a escola e as professoras daquela turma estavam vivenciando. Foram inúteis as tentativas de alterar o posicionamento da professora frente às situações presenciadas (as agressões verbais e físicas). Ao ser questionada sobre o motivo da sua decisão de não interferir, ela relatou: "por diversas vezes tentei interferir, mas, foram tentativas frustradas; cheguei a me machucar; já chamamos os pais, fizemos reunião com a direção, mas o índice de violência nesta turma é muito grande".

Notoriamente, as professoras não conseguiam manter uma relação pedagógica com os alunos e, da mesma forma, os alunos também não conseguiam êxito na relação aproximativa alunos-professoras. Consequentemente, havia uma gestão em sala de aula frágil, com papéis confusos, distorcidos, ou seja, os alunos tomavam decisões nas situações problemas e as professoras recuavam por medo de tomarem para si a responsabilidade de garantir as condições mínimas de organização do ambiente para a ocorrência da aula.

O clima organizacional da sala de aula era bastante hostil. Todos os dias os discentes já chegavam prontos para ofender as professoras. De acordo com o relato da docente A, alguns pais eram informados sobre as situações, mas não havia nenhum posicionamento. Os pais alegavam que "não sabiam o que fazer; que esses tipos de comportamentos também aconteciam em suas residências".

Todavia, se a família não consegue administrar tais comportamentos, é necessário que aconteça uma intervenção maior. Segundo Tiba (1996, p.179), "um desrespeito aos pais pode ser relevado, aos professores já implica em advertência, e às autoridades sociais, há punição".

O que se pode, então, afirmar é que a escola, sobretudo as professoras que convivem diretamente com os discentes, não recebem formação acadêmica para o gerenciamento desses conflitos, fazendo-se necessária e evidente uma formação continuada que esclareça e discuta diretamente a indisciplina e os comportamentos agressivos no contexto escolar, especialmente em sala de aula, que possa qualificar a gestão em sala de aula como ação intencional que esteja atenta às movimentações na didática, no tempo pedagógico, no espaço de aprendizagem, sobretudo na autoridade docente. 
No dizer de Gomes (2009, p.239),

a educação escolar não é possível sem a definição e a imposição de um conjunto de regras que devem ser respeitadas. É preciso que os alunos adquiram certos valores, certas crenças, certos hábitos, certas atitudes. Cumprindo um mandato social, o professor deve atuar no sentido de levá-los a respeitar certas regras. Na prática, este objetivo pressupõe e exige que o professor tenha autoridade.

Quando os professores perdem a autoridade, os alunos tomam para si o direito de definir suas próprias regras, surgindo como o adulto da relação, se impondo, autoritariamente, diante das professoras.

Durante o período de coparticipação, a escola sugeriu que as professoras propusessem atividades lúdicas para os alunos, uma vez que estavam se preparando para comemorar a data 12 de outubro, o "Dia das Crianças". As professoras aceitaram o pedido da coordenação, mas, não saiu como o esperado. As crianças continuavam irredutíveis, não sabiam estabelecer uma aproximação com as atividades lúdicas, pois já estavam sistematicamente acostumados com a rotina da sala de aula, sem movimentos, sem conteúdo que elevassem seu nível de raciocínio e movimentações corporais. Durante todas as atividades realizadas, agressões físicas e verbais ocorreram.

No último dia de coparticipação houve um enorme susto: as crianças tentaram quebrar o portão da escola na hora do intervalo. Na condição de estagiária, a primeira medida foi chamar a vice-diretora, mas, a mesma informou que naquele momento não sabia o que fazer, pois não teria como expulsar todos os alunos e que faria uma reunião com o Conselho de Classe para decidirem como procederiam em relação à agressividade da turma, uma vez que estavam sem o apoio familiar. Nesse dia foi muito desafiador colocálos dentro da sala de aula e acalmá-los, considerando que o nível de estresse estava elevado, tanto para os estudantes, quanto para as docentes. As crianças já estavam acostumadas com a falta de limites, sem nenhuma intervenção firme e definitiva e as professoras, por sua vez, só estavam esperando que o ano chegasse ao fim, para descansarem nas tão almejadas e justas férias.

Contudo, sabemos que a disciplina escolar não estabelece um diário de proposta para enfrentar os diversos tipos de comportamentos dos alunos, mas que é necessário fazer um levantamento dos maiores problemas, para que haja um enfrentamento conforme suas especificidades, principalmente nos casos de agressividade, pois, demandava uma intervenção emergencial.

Para isso é preciso, sempre que possível, antecipar-se ao aparecimento de problemas e só em último caso reparar os que inevitavelmente tiverem surgido, seja por causa da própria situação de ensino seja por fatores alheio à dinâmica escolar (GOTZENS, 2003, p. 22).

Diante de tudo que o que foi relatado, não foi possível garantir as condições pedagógicas mínimas para a continuidade do estágio na turma do $3^{\circ}$ ano, sendo indicado pela orientação do Estágio Curricular o remanejamento para a turma do $2^{\circ}$ ano, com um número menor de alunos e duas professoras.

\section{DIMENSÃO PRÁTICA DA GESTÃO EM SALA DE AULA}

Iniciar uma gestão em sala de aula demanda do profissional da educação, neste caso o professor, conhecer a história e os fundamentos das disciplinas, que garantem um maior aproveitamento na realização de atividades propostas para os discentes, lançando o olhar para ampliar a visão do que fazer e do ser no cotidiano pedagógico.

A reflexão sobre a prática é um momento crucial para o desenvolvimento dos futuros trabalhos educacionais. Conforme diz Freire (1996, p.44), "é pensando criticamente a prática de hoje ou de ontem que se pode melhorar a próxima prática". Com isso, fica bastante evidente que o professor precisa estar sempre verificando e reelaborando seu planejamento e suas estratégias de ensinagem.

E, foi neste contexto que ao entrar na turma do $2^{\circ}$ ano do Ensino Fundamental, observou-se a estratégia didática e a dinâmica pedagógica das professoras. No primeiro momento, também foi possível levantar dados sobre aspectos característicos da turma. Nesse cenário, se fez necessário realizar um trabalho diagnóstico com os alunos, a fim de identificar o nível de compreensão dos discentes acerca dos conteúdos previstos para aquele período letivo, de acordo com os Parâmetros Curriculares Nacional (PCN's $1^{\circ}$ ao $5^{\circ}$ ano). 
Nessa ocasião, também foi necessário fazer um breve reconhecimento do espaço físico da sala de aula. Uma vez que, a sala de aula como espaço se realiza enquanto vivenciado. Contudo, é necessário definirmos o conceito de espaço. Portanto, tomamos como referência os constructos teóricos de Michel de Certeau (2005), Craidy e Kaercher (1998). Para Certeau (2005, p.201-203),

[...] o espaço é um cruzamento de móveis... É de certo modo animado pelo conjunto dos movimentos que aí se desdobram. Espaço é o efeito produzido pelas operações que o orientam, o circunstanciam, o temporalizam e o levam a funcionar em unidade polivalente de programas conflituais, ou de proximidades contratuais.

Ao tomarmos de empréstimo a noção de espaço de Certeau, estamos concordando que é a atividade que qualifica o espaço (CERTEAU, 2005). Isso pode parecer sem muita importância, mas muda tudo quando decidimos pensar a sala de aula como um lugar de ensinagem, mediado na e pela gestão da aprendizagem. É importante especificar que uma sala de aula bem estruturada, decorre de um bom preparo físico, epistemológico e curricular.

Segundo Craidy e Kaercher (1998, p.65), “com relação à organização dos espaços internos das salas é fundamental partimos do entendimento de que este espaço não pode ser visto como um pano de fundo e sim como parte integrante da ação pedagógica [...]”.

Foi pensando em todas essas particularidades que se manteve uma aproximação entre a teoria e a prática para elucidar com mais precisão o trabalho pedagógico, o qual proporcionou resultado eficaz e satisfatório.

A regência no estágio ocorreu ao longo de duas semanas. Na primeira semana foram elaboradas atividades que mexeram com a rotina das crianças, ou seja, as crianças estavam presas ao quadro e ao caderno. Por não haver atividades lúdicas, então, todas as atividades da primeira semana envolviam pesquisas, recortes e colagens, que foi possível movimentar as crianças em grupos diferentes.

No primeiro dia houve resistência dos alunos para a realização dessas atividades. Foram planejadas atividades em grupos e a turma sugeriu que fossem em dupla ou individual. Na negociação didática, tanto os estudantes quanto a estagiária regente puderam apresentar os argumentos para justificarem seus posicionamentos. Um dos pontos altos desse momento foi a criação de um ambiente de confiança e respeito, sempre garantido o direito a vez e a voz de todos. Entretanto, também foi deixado claro que após as discussões e definição dos procedimentos mais adequados, todos se comprometeriam a decisão e realização das atividades. Desse modo, a mediação didática considerou dimensões da relação afetiva entre alunos-conteúdo-estagiária, além do lugar da autoridade docente na gestão em sala de aula.

Diante desse posicionamento, Furlani (2000, p. 37) esclarece que,

nesta concepção, o professor exerce a autoridade que lhe é atribuída para o desempenho dos papéis que facilitam um clima de negociação normal - isto é, com conflitos - dentro do qual o poder do aluno pode ser exercido de forma que haja influências mútuas.

Durante toda a regência, as crianças foram provocadas para interagirem com todas as disciplinas, de maneira significativa. Essa interação era estabelecida por meio de debates pedagogicamente mediados, a fim de capturar aquilo que foi compreendido e o modo como expressavam o aprendido por elas.

Com base nos vários conteúdos propostos pelos PCN's dos anos iniciais foram trabalhados no período de regência, dois temas transversais que acompanharam todos as atividades: o primeiro foi a ética que engloba respeito mútuo, justiça, diálogo e solidariedade; o segundo tema foi saúde, que está presente nas relações com o meio físico, social e cultural, implicando, sobretudo, no consumismo desenfreado, a desnutrição e estilos de vida pessoal.

Para o trabalho com ludicidade, primeiramente foram levantadas junto às docentes da turma, quais eram as brincadeiras que os alunos gostavam de realizar durante o recreio. Ela disse que não deixava as crianças saírem da sala de aula. Essa proibição de sair para brincar refletia num desânimo e apatia visíveis das crianças. Ficavam sentadas na maior parte do recreio; os meninos brincavam de cartas e as meninas ficavam apenas conversando. 
Foi aí que resolvi convidar a todos para brincarem de Adoleta ${ }^{4}$. No primeiro momento, somente as meninas aceitaram o convite; após uns 10 minutos, os meninos foram se aproximando. Quando dei conta da situação, estavam todos em um círculo enorme brincando de Adoleta. Foi uma experiência muito interessante! Depois disso, todos os dias eles queriam repetir a brincadeira.

Na segunda semana de regência, propus outras brincadeiras: trazendo elásticos, músicas de roda, sugerindo também que brincassem de pega-pega, futebol, bambolê entre outras. Uma das crianças, na hora do pega-pega, se sentiu tonta e me disse o seguinte: "professora vou descansar um pouquinho, não sou acostumada correr, estou me sentindo um pouco tonta". Aquilo me deixou um pouco perplexa, crianças sem condicionamento físico, recolhidas dentro de uma sala de aula. Após cada brincadeira, os alunos me abraçavam e diziam: "Professora amo você! Nunca nenhuma professora deixou a gente brincar de correr, de queimada. A senhora é nota dez!".

Para Barbosa (1998, p.57),

é importante que o educador observe o que as crianças brincam, como estas brincadeiras se desenvolvem, o que mais gostam de fazer, em que espaços preferem ficar, o que mais lhes chamam mais atenção, em que momentos do dia estão mais tranquilos ou mais agitados. Este conhecimento é fundamental para que a estruturação espaço-temporal tenha significado.

Para garantir uma aprendizagem mais leve e dinâmica com a participação das crianças, é essencial que a didática seja extremamente pensada e articulada. Foi possível constatar que as crianças, por sua vez, não exercitavam a autonomia para escolherem suas brincadeiras.

Por fim, para encerrar o estágio supervisionado, foi realizado um piquenique de frutas com as participações das crianças e professoras, mostrando o quanto é saborosa uma alimentação saudável com alimentos que fornecem energia para o corpo humano. Nesse momento, também foi realizada a entrega de lembrancinhas para as crianças e os agradecimentos às professoras e a direção da escola.

\section{CONSIDERAÇÕES}

Do percurso inicial até ao momento final deste trabalho se mantém clara a intenção de problematizar aspectos da gestão em sala de aula no Estágio Curricular do Curso de Pedagogia. Essa gestão envolve tomada de decisão e encaminhamentos de situações relacionadas à aprendizagem, a conduta e a interação. Esta visão possibilita uma aproximação concreta com a dinâmica da sala de aula como um espaço mobilizado, mediado e praticado pela ensinagem.

A ideia que permaneceu firme foi a de socializar experiências e percepções formativas à luz da temática, pois, as ações docentes são fortemente marcadas pelo modo como percebem, codificam e ressignificam suas práticas, reconhecendo tais práticas como um espaço de produção de saberes, na medida em que constituem e são constituídas no exercício da profissão.

Nesse processo, destacou-se a autoridade do professor como condição essencial, defendida como a capacidade de fazer o outro autor, sendo necessária numa educação que visa exercitar a autonomia dos alunos, focalizando a gestão da aprendizagem no espaço sala de aula, abordando ações de mediação para que haja aprendizagem significativa dos conteúdos.

\footnotetext{
${ }^{4}$ Essa brincadeira, as crianças devem formar uma roda; a seguir, precisam intercalar suas mãos colocando a palma da mão direita sobre a esquerda do colega ao lado. Elas devem movimentar apenas a mão direita de forma a bater com a palma no dorso da mão direita do seu vizinho. Este movimento segue a música. Ao encerrar a silabação musical, o ultimo que tiver recebido a "palma" sai da brincadeira. Música: Adoleta- Lê peti peti polá- Lê café com chocoláAdoleta- Puxa o rabo do Tatu- Quem saiu foi- TU.
} 
O que se pode observar ao longo do período de Estágio é que as discussões trazidas nesse estudo sobre a gestão em sala de aula permitiram o aprofundamento das dimensões que envolvem a gestão do conhecimento, a gestão de grupo e as relações interpessoais, evidenciando a importância da gestão em âmbito escolar nos anos iniciais do Ensino Fundamental.

A gestão docente tem como função nortear todo o procedimento das relações de ensinagem, promovendo a doçura e o amargo do seu processo curricular. Essa nova exigência da ação do professor como gestor, pressupõe a maneira mais coerente de desenvolver o processo de educação.

Nesse gestor se encontra a intenção da autonomia de fazer acontecer a liderança, a mediação, a comunicação, a autoridade, a gerencia do tempo, promovendo, assim, a novas situações de aprendizagem. Essa caracterização da gestão articula uma responsabilidade na produção da autonomia frente à sociedade. Não se trata apenas da gestão sala de aula, mas no que ela promove enquanto processo educativo.

A experiência do Estágio Curricular nos anos iniciais do Ensino Fundamental possibilitou maior aproximação com o campo da gestão em sala de aula e o aprimoramento da relação teoria-prática no suporte pedagógico através das práticas de intervenção desenvolvidas nesse tempo de vivências. Tal atividade contribuiu, sobremaneira, para que a aluna estagiária tomasse o campo da gestão em sala de aula como objeto de pesquisa em sua investigação monográfica de conclusão de curso, alargando a visão pelo aumento da capacidade de observação e análise do fenômeno em tela, vislumbrando caminhos e cenários de atuação docentes, capazes de fortalecer o exercício da gestão do processo educativo no espaço sala de aula.

\section{REFERÊNCIAS}

[1] ABREU, Manuel Veigas. Cinco Ensaios da Motivação. Coimbra: Almeina, 1998.

[2] BARBOSA, Maria Carmem, HON, Maria da Graça Souza. Organização do espaço e do tempo na escola infantil. In: CRAIDY, Carmem Maria e KAERCHER, Gládis Elise Pereira da Silva (Org.). Educação Infantil pra que te quero? Porto Alegre: Universidade do Rio Grade do Sul, 1998.

[3] CRAIDY, Carmem Maria, KERCHER, Gláidis Elise Pereira da Silva. Educação Infantil: pra que te quero? Porto Alegre: Universidade Federal do Rio Grande do Sul, 1998.

[4] CERTEAU, Michel de. A invenção do cotidiano: 1.artes de fazer. Petrópolis: Vozes, 2005.

[5] FREIRE, Paulo. Pedagogia do Oprimido. $13^{\circ}$ ed. Rio de Janeiro, Paz e Terra, 1983.

[6] _ـ_ Paulo. Pedagogia da Autonomia: saberes necessários à prática educativa. São Paulo: Paz e Terra, 1996.

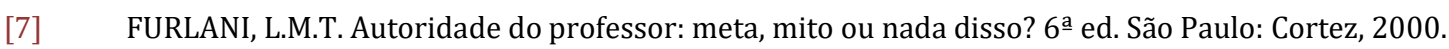

[8] GOMES, Carlos Alberto. Poder, autoridade e liderança institucional na escola e na sala de aula: perspectivas sociológicas clássicas. Ensaio: aval. pol. públ. Educ., Rio de Janeiro, v. 17, n. 63, p. 235-262, abr./jun. 2009.

[9] GOTIZENS, Concepcion. A disciplina escolar: prevenção e intervenções nos problemas de comportamento. 2 a Edição, Porto Alegre, Editora Artmed, 2003.

[10] MOREIRA, Herivelto; CALEFFE, Luiz Gonzaga. Metodologia da Pesquisa para professor pesquisador. Rio de Janeiro: DP\&A, 2006.

[11] SOARES, Magda Becker. Letramento e alfabetização: as muitas facetas. Revista Brasileira de Educação. n. 25, p. 5-17, jan./abr. 2004.

[12] TIBA, Içami. Disciplina, limite na medida certa. São Paulo, Editora Gente, 1996.

[13] UNIVERSIDADE DO ESTADO DA BAHIA. RESOLUÇÃO № 2.016/2019. (Publicada no D.0.E. de 21-09-2019, pág. 36). Disponível em: https://portal.uneb.br/conselhos/wp-content/uploads/sites/103/2019/09/2016-consepeRes.-Regulamento-de-Estagio.pdf Acesso em: 12 jul. 2020. 


\section{Capítulo 3}

As influências da relação pedagógica professor-aluno no processo de ensino-aprendizagem no Ensino Fundamental

Juliana de Souza Costa

Edileuza Fernandes Silva

Resumo: A relação pedagógica professor-aluno é intrínseca ao processo de ensinoaprendizagem e determinante para o êxito do ato educativo, compreendido como prática social relacional. Neste texto, buscou-se analisar as influências dessa relação nas aprendizagens de estudantes de uma turma de 5o ano do Ensino Fundamental de uma escola pública do Distrito Federal. A pesquisa de abordagem qualitativa do tipo estudo de caso, utilizou para levantamento de dados: análise documental do projeto políticopedagógico da escola, observação de aulas, entrevista semiestruturada com a professora, grupo focal e desenho projetivo com os estudantes. 0 referencial teórico baseia-se em Cunha (2012), Morales (2008), Postic (1990), Veiga (2008, 2019), entre outros. Os resultados apontam que a relação pedagógica é afetiva, intencional, gera feedback à professora e aos alunos; é dialógica e repercute nas aprendizagens dos educandos.

Palavras-chave: Didática. Educação. Ensino-aprendizagem. Ensino Fundamental. Relação professor-aluno. 


\section{INTRODUÇ̃̃O}

Este texto analisa dados de pesquisa realizada no período de agosto de 2019 a julho de 2020, no âmbito do Programa de Iniciação Científica da Universidade de Brasília (ProIC), edital 2019/2020 e se insere no conjunto de produções científicas desenvolvidas pelo Grupo de Estudos e Pesquisa sobre Trabalho Docente, Didática e Organização do Trabalho Pedagógico - PRODOCÊNCIA, cadastrado no CNPq. Além disso, foi apresentado em formato de comunicação oral no VII Congresso Nacional de Educação, XV Encontro de Pesquisa em Educação da Região Centro-Oeste da ANPED, 26ํㅡ Congresso de Iniciação Científica da UnB e 17ํ do Distrito Federal em 2020.

No atual contexto de sociedade capitalista - em que o indivíduo se sobrepõe ao coletivo, o ter ao ser, onde as novas tecnologias de comunicação e informação, ao mesmo tempo em que aproximam as pessoas, tornam as relações mais fluidas - discutir a relação professor-aluno é um desafio, dada a complexidade deste objeto de estudo. 0 contexto de pandemia do Coronavírus, momento em que se deu a escrita deste texto, exigiu dos sistemas de ensino a adoção de medidas de isolamento com repercussão na oferta presencial do ensino na Educação Básica e Superior, o que pôs em evidência a relevância da relação professor-aluno, demonstrando que essa relação é central no processo pedagógico e para as aprendizagens dos estudantes.

A necessidade de distanciamento emergencial tem mostrado o valor do contato face a face, olho no olho, do tocar o outro, atos aparentemente corriqueiros, são agora lembrados como constituintes da condição humana. Os sujeitos estão diante da exigência de desenvolver as atividades pedagógicas por meio do ensino online, mediado pelas tecnologias, pelos materiais impressos, pelas videoaulas. Percebe-se quão desafiador tem sido o isolamento social no contexto de pandemia da Covid-19 para os protagonistas do ato educativo.

A relação professor-aluno é categoria central do trabalho pedagógico em sala de aula. 0 ensino remoto no contexto da pandemia do Coronavírus revelou que essa relação é responsável pela personalização do processo ensino-aprendizagem e fundamental para a constituição dos sujeitos históricos e sociais. A relação professor-aluno é sempre mediada pelo conhecimento, o que imprime a ela o sentido pedagógico. Em sala de aula, a interação ocorre entre professor e alunos e entre alunos e alunos, em um processo relacional que contribui para a formação humana.

O contato interpessoal é necessário para o processo de ensino-aprendizagem e para a formação humana dos sujeitos, haja vista a unidade entre as relações professor-aluno e ensino-aprendizagem, intrínsecas ao processo pedagógico e determinantes para o êxito do ato educativo, compreendido como prática social relacional. Isso porque os seres humanos necessitam estar uns com os outros, convivendo, socializando e aprendendo.

Estudos de pesquisadores como Santos (2015), Vaz (2017), Ribeiro (2017), Barbosa (2017) e Carvalho (2015) enfatizam a afetividade como inerente à relação pedagógica destacando que os sentimentos e emoções são características presentes em todos os relacionamentos humanos e não seria diferente entre professor e aluno. Os estudos apontaram que um bom relacionamento é essencial para o processo de ensino-aprendizagem e para a organização do trabalho pedagógico.

Para contribuir com o debate da temática, a pesquisa realizada apresenta um diferencial - os sujeitos pesquisados mantinham uma relação pedagógica há três anos consecutivos, o que pressupõe intensidade e constância que podem sugerir um tipo de relação a ser considerada, ou não, propícia às aprendizagens dos estudantes. Assim, buscou-se ouvir os protagonistas da aula - professor e alunos - para discutir as influências que a relação entre eles têm no processo de ensino-aprendizagem e compreender a dinâmica das relações sociais em sala de aula de uma turma de 5o ano do Ensino Fundamental de uma escola pública do Distrito Federal.

A pesquisa de abordagem qualitativa do tipo estudo de caso (LÜDKE; ANDRÉ, 1986) foi desenvolvida em uma escola identificada por Mundinho Mágico (nome fictício) localizada na Região Administrativa do Plano Piloto e criada em 1960. A instituição oferece o Ensino Fundamental Anos Iniciais para estudantes de 6 a 10 anos $\left(1^{\circ}\right.$ a $5^{\circ}$ ano). Em 2019, ano de realização da pesquisa, atendia a 246 alunos nos dois turnos, em oito salas de aula. 
A turma composta por treze estudantes com idade entre 10 e 11 anos, 2 com atendimento às necessidades educacionais especiais, caracterizando a turma como inclusiva, por isso, reduzida. 0 critério de escolha da turma de $5^{\circ}$ ano considerou a maturidade dos estudantes para se expressarem sobre o tema. A professora da turma será identificada como Joyce (nome fictício), com mais de 25 anos de magistério e trabalha na escola pesquisada há dez anos. Cursou magistério no ensino médio, fez graduação em Pedagogia e pósgraduação em Gestão Escolar.

A escuta da professora e dos alunos possibilitou compreender como a relação pedagógica se constitui e interfere nas práticas de ensino do professor e, consequentemente, na aprendizagem dos estudantes. Para o levantamento dos dados, foram utilizados: a) questionário para caracterização dos pesquisados; b) análise do projeto político-pedagógico (PPP) da escola; c) observação de 20 horas-aulas; d) entrevista semiestruturada realizada com a professora; e) contação de história; f) grupo focal; e g) desenho projetivo com estudantes.

\section{ESCOLA: ESPAÇO DE RELAÇÕES}

A escola é espaço de relações e interações, nela a criança passa do convívio familiar ao convívio no meio social. Nessa passagem, os profissionais da educação e colegas de turma são essenciais para a socialização, entendida como o processo de desenvolvimento do sentimento coletivo da solidariedade social e do espírito de cooperação, adquirindo os hábitos que os capacitam para viver numa sociedade. A convivência na escola aliada à apropriação dos saberes científicos são indispensáveis ao desenvolvimento e aprendizagem das crianças.

Desde os primórdios da existência humana, a educação tem garantido às gerações mais novas o aprendizado da experiência acumulada pela humanidade ao longo do tempo. Nesse processo, os seres humanos aprendem mais com os outros do que sozinhos, o que faz com que a educação seja uma prática social por excelência (FUENTES; FERREIRA, 2017). Na escola, é pela "dimensão social que os sujeitos efetivam o trabalho pedagógico, constituindo de fato o processo educativo" (Idem, p. 729). Este trabalho tem como objetivo o ensinar e o aprender com vistas ao cumprimento da finalidade da educação prevista na Constituição Federal Brasileira de 1988: pleno desenvolvimento da pessoa, seu preparo para o exercício da cidadania e sua qualificação para o trabalho. 0 ensino é o trabalho do professor e a aprendizagem uma atividade do estudante. Contudo, ensino e aprendizagem constituem uma relação recíproca, onde ambos são facetas de um mesmo processo (LIBÂNEO, 1990).

Logo, não há ensino sem aprendizagem ou vice-versa e estes ocorrem de forma planejada e sistematizada, principalmente nos espaços de aula que para Veiga (2008), é um espaço privilegiado da vida pedagógica, organizada segundo os seguintes elementos estruturantes: o para quê (intencionalidade), o quê (conteúdo cultural), como (metodologia), com que (recursos didáticos), o quê, como (avaliação), onde (espaço), quando (tempo), quem, para quem (os agentes da aula).

Esses elementos se articulam e se concretizam na aula pela relação estabelecida entre professor-aluno. Cordeiro (2011) salienta que, durante a aula, professor e alunos estão em constante interação, em um momento de troca de influências (CUNHA, 2012) evidenciando a constituição destes como sujeitos históricos e de relações. Entretanto, essa relação diferencia-se das demais relações sociais, visto que, encontra-se mediada pelo conhecimento, o que a caracteriza como essencialmente pedagógica, pois seu objetivo principal é ensinar e aprender.

A relação professor-aluno além de ser central na aula, também está envolta dos demais componentes e situações de sala de aula e do processo de ensino-aprendizagem. Em face desses elementos, entende-se a relação professor-aluno como "o conjunto de relações sociais que se estabelecem entre o educador e aqueles que educa para atingir objetivos educativos" (POSTIC, 1990, p. 12). Nesse sentido, professor e estudantes são agentes da aula (VEIGA, 2008), em que um tem o papel de ensinar e o outro de aprender, mesmo que, por vezes, esses papéis se alternem. Ambos aprendem e ensinam, numa relação dialógica que não é única nem uniforme, pois a depender das condições em que se realiza o ato de ensinar, diferem-se as relações estabelecidas entre o professor e seus alunos (POSTIC, 1990). 
Dessa forma, a depender dos sujeitos e do clima que há entre eles, a relação será diferente. Para Cunha (2012), existem aspectos que perpassam essa relação, como: o conteúdo e as habilidades de ensino; a metodologia, o clima de sala de aula e os aspectos afetivos. Cordeiro (2011) complementa indicando determinadas dimensões que influem nesse relacionamento:

- espacial - diz respeito ao espaço escolar e da sala de aula, dos arranjos produzidos com finalidades educativas e que podem favorecer uma maior ou menor interação entre os sujeitos. Morales (2008) acrescenta ainda que um ambiente de segurança, paz e confiança é necessário à aprendizagem e à internalização do que se está aprendendo;

- temporal - relaciona-se ao tempo das atividades didático-pedagógica e sobre como o tempo cronológico pode ser transformado em tempo pedagógico (SILVA, 2011);

- linguística - expressa o poder da linguagem, da comunicação, na constituição de relações mais dialógicas, respeitosas e interativas;

- pessoal - tendo em vista que os valores, experiências e visões de mundo de professor e estudantes são mobilizados na relação pedagógica. Além disso, professor e aluno afetam-se mutuamente em um círculo potencializador de uma boa relação e de um bom aprendizado. Para Morales (2008), há conexão entre a conduta docente e a percepção e motivação dos estudantes, como também entre dedicação do aluno e conduta do professor;

- cognitiva - a relação professor-aluno é mediada pelo conhecimento, o que a caracteriza como essencialmente pedagógica e voltada à socialização de saberes produzidos pela humanidade.

\section{RELAÇÃO PROFESSOR-ALUNO: O ESCRITO, O OBSERVADO E 0 DITO}

A análise do PPP da escola objetivou identificar a concepção de ensino-aprendizagem e de relação professor-aluno expressas pelos profissionais e retratadas nesse projeto. A observação de aulas foi realizada com o intuito de perceber como se dá essa relação na turma. A entrevista, o grupo focal e o desenho projetivo contribuíram para identificar as percepções da professora e dos estudantes acerca da relação professor-aluno e as influências no processo de ensino-aprendizagem.

\section{A RELAÇÃO PROFESSOR-ALUNO NO PROJETO DA ESCOLA: O ESCRITO}

Embora o PPP da escola não contemple explicitamente objetivos e ações voltadas à relação pedagógica, há indicação de que o processo educativo deve permitir, ao educador e aos educandos, o aprender a aprender, o aprender a ser, o aprender a fazer e o aprender a conviver, numa construção coletiva de conhecimento, colocando o aprendiz como foco (MUNDINHO MÁGICO, 2018), tendo o reconhecimento do protagonismo do professor e do aluno no processo de ensino-aprendizagem. 0 aprender a conviver, de acordo com Delors, possibilita "a compreensão do outro e a percepção das interdependências - realizar projetos comuns e preparar-se para gerir conflitos - no respeito pelos valores do pluralismo, da compreensão mútua e da paz" (2001, p. 102).

Foi possível identificar ainda, na seção do PPP que trata de concepções, práticas e estratégias de avaliação, a proposição de que ao avaliar o estudante, o professor o auxilie, respeitando suas diferenças individuais e socioculturais, por meio de uma relação de liberdade, cooperação e diálogo que favoreça o seu progresso contínuo e a autoavaliação. Há ênfase ao diálogo como comunicação horizontal entre docente e discente de igual para igual em que os estudantes possam manifestar livremente opiniões, ideias, dúvidas e anseios.

A seguir discute-se, a partir de observações de situações de aula, como essas relações se constituem.

\section{RELAÇÃO PROFESSOR-ALUNO NA SALA DE AULA}

As observações de sala de aula foram significativas para o estudo, tendo em vista que a percepção que o professor tem do aluno e este do docente determina suas formas de agir e reagir em situações educativas (POSTIC, 1990), podendo indicar o tipo de relação que constituem, se é voltada à criação de vínculos de dependência ou de libertação (Idem). 
Nas aulas, a comunicação entre eles era horizontal, assimétrica, a docente procurava escutar as opiniões dos estudantes, mas sempre mantendo a hierarquia da posição que assume. Desenvolvia o seu trabalho com certo rigor e com a preocupação com a disciplina dos alunos. Ser um educador democrático e dialógico, de fato, não significa que tenha que se omitir, e sim, estar presente tanto como mestre quanto como humano, conservando toda sua autoridade moral e intelectual, sem impô-la e sim colocando essa autoridade a seu serviço (POSTIC, 1990) e também a serviço das aprendizagens dos alunos.

Ao chegar em sala de aula, Joyce era sempre recebida com abraços e elogios pelas crianças, ávidas por falar sobre suas vidas, sobre os acontecimentos recentes, sendo escutadas com atenção pela professora. Percebia-se a confiança, amizade, carinho, respeito e a credibilidade entre ambos, sugerindo afetividade na relação. Nesse sentido, Freire chama a atenção que é "preciso descartar como falsa a separação radical entre seriedade docente e afetividade" (2017, p. 138), ser um professor democrático e afetuoso não o torna menos autoridade e menos respeitado e não o impede de valorizar a sua profissão.

$\mathrm{Na}$ aula, os educandos recebiam bem as atividades propostas, escutavam com atenção, questionavam, tiravam dúvidas, expunham seus raciocínios sobre o conteúdo e opiniões sobre a prática docente, havendo expressão da disponibilidade da professora para o diálogo (FREIRE, 2017). A docente explicava os conteúdos e atividades com tranquilidade, pausadamente, concedendo atenção a todos e auxiliando principalmente os estudantes com dificuldades. Utilizava o quadro branco, o livro didático, apostilas de exercícios e jogos como recursos didático-pedagógicos, meios diversificados que favoreciam as aprendizagens dos estudantes. $\mathrm{Na}$ aula, a professora também tomava decisões com os estudantes, orientando e conduzindo o processo didático (VEIGA, et al, 2019) contribuindo assim, para a relação pedagógica a serviço da aprendizagem.

\section{RELAÇÃO PROFESSOR-ALUNO: PERCEPÇÕES DA PROFESSORA}

As concepções docentes acerca de ensino e aprendizagem interferem em suas práticas pedagógicas e na relação com os estudantes. Assim, questionou-se à Joyce sobre o que é ensinar e aprender: "É uma troca, onde ao mesmo tempo em que ensino, também aprendo". E aprender: "É acumular conhecimento, se renovar e crescer". A professora demonstra conflito conceitual, pois aprender se orienta pela concepção bancária (FREIRE, 1987), ao mesmo tempo em que destaca ser um processo de crescimento, aprimoramento e potencialização das capacidades humanas. Dessa forma, demonstra compreender que ensinar é mais do que transmitir conhecimento, é um processo dialógico que favorece a formação humana e cognitiva.

Para a docente, o processo de ensino-aprendizagem acontece a todo momento em sala de aula na interação entre professor-aluno, sugerindo que "o trabalho pedagógico é uma atividade interacional ou relacional, isto é, se realiza com base e em face de um conjunto de interações pessoais entre professor e alunos" (CORDEIRO, 2011, p. 66). Esse tipo de trabalho favorece a interação recíproca e dialógica.

Questionada acerca da relação pedagógica que constrói em sala de aula, Joyce confessa ser "um caso atípico", por estar há três anos lecionando com a turma e, portanto, mais do que afetividade, "criou-se um laço de amizade com os educandos e as famílias". No entanto, a professora destaca que mesmo com a relação de amizade, ela é exigente e cobra muito dos estudantes, ou seja, a afetividade não interfere no dever docente (FREIRE, 2017).

Para a docente, há pontos positivos de uma relação pedagógica construída em longo tempo: "a relação que você sabe quem é quem e eles já te conhecem, até pelo seu jeito de olhar". Ela compreende que quando ambos os parceiros se conhecem, isto torna-se um facilitador, tanto do ensino quanto da aprendizagem, pois ao conhecer as dificuldades das crianças, pode organizar e planejar o trabalho pedagógico a fim de alcançar todos os estudantes. Além disso, evidencia como ponto negativo que "eles tinham que ter outras experiências com outros profissionais", para aprenderem de diferentes formas.

Questionada sobre o que ela considera mais importante na relação que tem com os educandos, expressou: "uma relação boa com a turma faz com que eu me sinta feliz em dar aula e os estudantes se sintam tranquilos para aprender". Segundo Morales (2008), a relação com os alunos pode e deve incidir positivamente tanto na aprendizagem, como na satisfação pessoal e profissional do docente. Joyce destaca ainda que a confiança do discente no docente traz tranquilidade e abertura para expor opiniões, perguntar e tirar dúvidas. Logo, abertura para a construção do conhecimento. 
Questionou-se ainda, como ela acredita que os alunos a veem como professora. Em sua fala, diz que é "aquela coisa de um abraço, [...] alguns vão te mostrar tudo e outros você vai perceber nessas pequenas coisas e até de repente em um pequeno gesto". A docente demonstra consciência de que a forma como os estudantes a veem influencia na aprendizagem e reconhece que isso é fundamental para obter o feedback (retorno) sobre sua prática pedagógica.

Ela reconhece a importância do seu papel no direcionamento das atividades em sala de aula: "o educador é fundamental para motivar os educandos". De acordo com Jesus (2003), o professor que quer seus alunos motivados deve dar o exemplo e expressar entusiasmo e motivação. No mesmo sentido, a docente também atribui ao interesse que os estudantes demonstram pelas aulas e pela convivência com ela como motivação para que se empenhe cada vez mais. Reforça-se assim, que a relação pedagógica é balizadora do trabalho pedagógico desenvolvido de forma participativa e democrática.

\section{RELAÇÃO PROFESSOR-ALUNO: PERCEPÇÕES DOS ESTUDANTES}

Os estudantes também são protagonistas da relação pedagógica em sala de aula junto aos professores, sem eles a aula não existe. As percepções dos alunos são imprescindíveis para compreender a relação pedagógica que se estabelece. Para isso, realizou-se grupo focal com sete estudantes. Inicialmente, preparou-se o ambiente para os estudantes se expressarem a respeito do tema. Para isso, foi realizada a contação da história: "Professora nova... E agora?" de autoria da pesquisadora.

Essa história aflorou a imaginação e proporcionou a criação do desenho que projetaria a forma como os alunos percebem a professora, o que eles mais gostam nela e o que mudariam. A história contextualizou a discussão do grupo focal, no qual foi perguntado: "como é a relação com a professora em sala de aula? Como essa relação influencia na sua vontade de aprender? 0 que você acha de estar há três anos nessa relação?".

Os estudantes consideraram a relação com a professora Joyce boa e baseada no diálogo e enalteceram suas características: alta, linda, bonita, maravilhosa, melhor professora, inteligente, legal e, por vezes, brava. Na direção do que discute Postic (1990), os discentes tendem a conceder mais importância às qualidades humanas e relacionais ao representar o docente do que às atividades intelectuais e profissionais. Joyce reconhece essas características ditas por eles, quando ressalta que é rígida, uma professora que cobra empenho e desempenho.

Durante o grupo focal, também veio à tona a questão da disciplina em sala de aula. Os educandos admitem a importância e necessidade da organização e disciplina em sala de aula, como expressa a estudante Bianca: "Se ela deixar tudo bagunçado, ninguém vai aprender nada, ela não vai conseguir ensinar direito. Ela tem que ser rígida às vezes, porque senão, ninguém vai prestar atenção, vai ficar tudo bagunçado".

Questionados se acham que a relação com a professora influencia na vontade de aprender, relataram que por já conhecerem bem a docente e existir uma boa relação entre eles, na maioria das vezes, não há medo de questionar e expressar opiniões. Em determinados momentos, a professora demonstrou impaciência com relação às perguntas dos alunos. Nesse sentido, foi observado um estudante esclarecer a um outro colega que disse ter receio de fazer perguntas à professora: "ué, fala que não entendeu e a Joyce explica, aí você: ahhhh". É perceptível pelas falas que essa abertura para o diálogo com Joyce não existia no começo da relação entre eles. Segundo Postic (1990), isso acontece, pois após a fase de ansiedade própria do encontro entre os parceiros, o educando passa a conhecer os sinais na interação e a decodificá-los, além de conseguir caracterizar o docente com o qual se relaciona no momento.

Os estudantes também expõem aspectos a respeito da prática pedagógica da docente, ressaltando que: "ela explica bem, quantas vezes for necessário, pergunta se todos entenderam, auxilia aqueles que ainda apresentam dificuldades ao realizar a tarefa". Sobre estarem há três anos com a mesma professora, destacam que é uma experiência interessante, pois têm mais intimidade e as explicações são mais enriquecedoras. Além disso, esclarecem que Joyce sabe o que eles dominam ou não, por isso pode retomar os conteúdos: "ela sabe as dificuldades de cada um e prepara uma aula equilibrada".

Nos desenhos do quadro 1, é possível visualizar que os educandos além de destacarem características físicas e relacionais da professora Joyce, expressam sentimentos e afetividade. Ademais, mostram-se ativos ao refletir e externar a respeito da prática pedagógica docente e de como ela orienta e organiza o processo de ensino-aprendizagem e o trabalho pedagógico. 
Destaca-se que a expressão da criança pelo desenho possui significação e conteúdo, favorecendo interpretações a partir de seu desenvolvimento gráfico (DERDYK, 1989). 0 desenho projetivo possibilita um processo cognitivo no qual o indivíduo é capaz de perpassar por suas experiências pessoais internalizadas (FERREIRA, 1998). Assim, a partir das narrativas das crianças e dos sentidos expressos pelos desenhos, percebe-se que a boa relação pedagógica professor-aluno resulta dos fatores apontados anteriormente e também de características pessoais, profissionais e humanas do docente. No caso estudado, a professora reúne conhecimentos específicos das áreas de conhecimento, didático-pedagógicos e das relações humanas, revelando que o ser e estar professora recebe influência das relações com os estudantes e também as influencia.

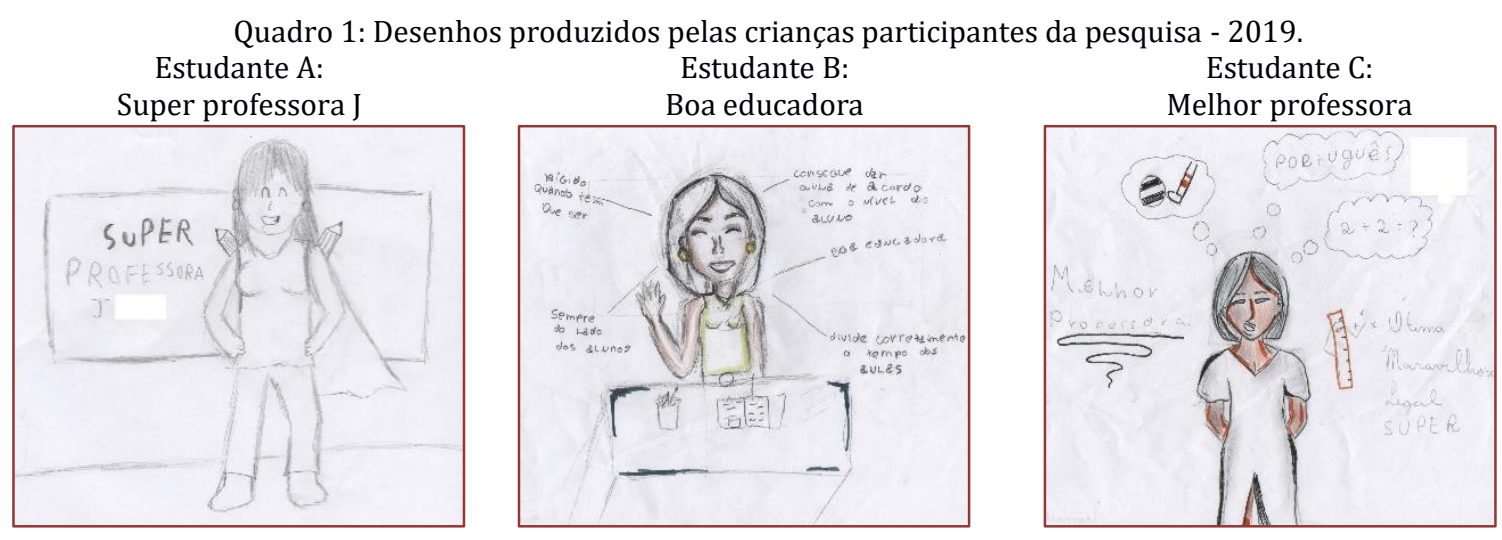

Fonte: desenhos de crianças participantes da pesquisa feitos após a contação de história.

\section{CONSIDERAÇÕES FINAIS}

Das análises dos dados, depreende-se que a relação pedagógica professor-aluno em uma turma de 5ํano do Ensino Fundamental de uma escola pública do DF é: a) afetiva, pautada em sentimentos e emoções; b) intencional vinculada aos objetivos de ensino-aprendizagem; c) geradora de feedback à professora que conhece as dificuldades de aprendizagem e intervém no processo e aos alunos que buscam tirar dúvidas; d) dialógica, favorecendo a comunicação e as aprendizagens dos alunos; e) de reciprocidade, essencial para que ambos se conheçam, se motivem e facilitem o processo de ensino-aprendizagem.

A relação pedagógica professor-aluno democrática, respeitosa e dialógica influencia o processo de ensinar e aprender, em situações que envolvem: a motivação dos educandos e do docente; a organização do trabalho pedagógico em prol de retomar os conteúdos e/ou reforçar práticas; a satisfação pessoal, profissional e felicidade ao lecionar; abertura para a aprendizagem a partir de um clima agradável e tranquilo na internalização do que se aprende. Por fim, a professora demonstra compreender que a forma como os estudantes a veem os influencia a manterem-se motivados à aprendizagem; e que a dedicação e vontade de aprender do estudante interferem em sua atuação e empenho no ato educativo.

Por fim, a relação pedagógica deixa marcas nos sujeitos, que quanto mais estabelecem uma relação de proximidade, mais influência têm um sobre o outro (CUNHA, 2012), tornando, assim, a relação pedagógica uma via de mão dupla, em que professor-aluno podem influir e ser reflexos para o ato educativo, onde as ações de ambos retroalimentam o relacionamento. Além disso, o ensino remoto em tempos de pandemia da Covid-19, suscitou o debate sobre o papel docente na formação dos estudantes para além da transmissão de conteúdos, mostrando que, por meio da relação pedagógica personalizada, o processo didático qualifica-se, sendo central para se pensar a educação de qualidade e comprometida com a aprendizagem dos educandos. 


\section{REFERÊNCIAS}

[1] BRASIL. Constituição da República Federativa do Brasil, 1988.

[2] BRASIL. Ministério da Educação. Educação: um tesouro a descobrir. - 5a ed. - São Paulo: Cortez; Brasília, DF: MEC: UNESCO, 2001.

[3] CORDEIRO, J. A relação pedagógica. In: UNIVERSIDADE ESTADUAL PAULISTA. Prograd. Caderno de Formação: formação de professores didática geral. São Paulo: Cultura Acadêmica, 2011, p. 66-79, v. 9.

[4] CUNHA, M. I. da. A relação professor-aluno. In: VEIGA, Ilma Passos Alencastro (coord). Repensando a didática. 29a ed. - Campinas, SP: Papirus, 2012.

[5] DERDYK, E. Formas de pensar o desenho: Desenvolvimento do grafismo infantil. São Paulo, SP: Scipione, 1989.

[6] FERREIRA, S. Imaginação e linguagem no desenho da criança. Campinas: Papirus, 1998.

[7] FREIRE, P. Pedagogia da autonomia: saberes necessários à prática educativa. 55a ed - Rio de Janeiro / São Paulo: Paz e Terra, 2017.

[8] FREIRE, P. Pedagogia do oprimido. 17a ed - Rio de Janeiro / São Paulo: Paz e Terra, 1987.

[9] FUENTES, R. C.; FERREIRA, L. S. Trabalho pedagógico: dimensões e possibilidade de práxis pedagógica. Perspectiva, Florianópolis, v. 35, n. 3, p. 722-737, jul./set. 2017.

[10] JESUS, S. N. de. Influência do professor sobre os alunos. 5ํㅡㄹ ed. Janeiro de 2003.

[11] LIBÂNEO, J. C. Didática. São Paulo: Cortez, 1990.

[12] LÜDKE, M.; ANDRÉ, M. E. A. Pesquisa em educação: abordagens qualitativas. São Paulo: E. P. U., 1986.

[13] MORALES, P. A relação professor-aluno: o que é, como se faz. 7ạ ed: junho de 2008. São Paulo, SP.

[14] POSTIC, M. A relação pedagógica. 1990. Coimbra Editora.

[15] Projeto Político-Pedagógico da Escola Classe Mundinho Mágico, Brasília, 2018.

[16] SILVA, E. F. da. Nove aulas inovadoras na universidade. Campinas, SP: Papirus, 2011.

[17] VEIGA, I. P. A. (org.). Aula: Gênese, dimensões, princípios e práticas. Campinas, SP: Papirus, 2008. Coleção magistério: formação e trabalho pedagógico.

[18] VEIGA, I. P. A. (org.). Relação pedagógica na aula da educação superior. Campinas, SP: Papirus, 2019. 


\section{Capítulo 4}

Panorama das pesquisas sobre interdisciplinaridade na Educação Básica

\section{Camila Aparecida Silva Rosa Marinelo}

Giovanna Velloso dos Santos

Márcia Maria Dias Reis Pacheco

Resumo: A lógica educacional atual é orientada a partir da premissa de que existe uma ligação intrínseca entre as áreas de conhecimento, que via de regra é quebrada no plano das disciplinaridades, o que faz do conhecimento e da prática pedagógica interdisciplinar a possibilidade de um fazer pedagógico pautado na totalidade. A fim de conhecer as publicações e o interesse acadêmico sobre a Interdisciplinaridade, vinculados à biblioteca digital Scientific Eletronic Library (Scielo) e a Coordenação de Aperfeiçoamento de Pessoal de Nível Superior (CAPES), realizou-se um panorama das pesquisas acerca do descritor Interdisciplinaridade. Buscou-se por artigos científicos publicados entre os anos de 2011 a 2017, utilizando-se de critérios pré-definidos para seleção. Como 2wresultado, foram identificados 440 artigos científicos, os quais em sua maioria, relacionados com área da saúde. Após uma análise primária, foram selecionados 12 artigos que atenderam aos critérios pré-definidos, o que fez observar certa escassez de artigos publicados sobre a Interdisciplinaridade ligada a educação básica.

Palavras-chave: Interdisciplinaridade; 2. Educação Básica; 3. Prática Docente. 


\section{INTRODUÇÃO}

Com a atual realidade da globalização, que traz complexidade às noções históricas e espaciais, além de um grande dinamismo nas relações políticas, econômicas e culturais, é preciso observar que o processo educacional, o qual traz a fragmentação do conhecimento como sendo fórmula para aprendizagem, acaba por apresentar uma proposta descontextualizada das necessidades dos sujeitos envolvidos no processo de ensino. Para Japiassu (2006), há contradição entre essas duas esferas, pois existe a complexidade e a interdependência das questões globais. Por outro lado, há a constância do sistema educacional em privilegiar os saberes fragmentados (disciplinarizados).

Dentre as finalidades e responsabilidades atribuídas as instituições educativas, preconizadas pelas leis que regem a Educação, destaca-se, a Constituição Federal de 1988 (2006, p. 134), que em seu Art. 205, propõe que a "[...] educação, direito de todos e dever do Estado e da família, será promovida e incentivada com a colaboração da sociedade, visando ao pleno desenvolvimento da pessoa, seu preparo para o exercício da cidadania e sua qualificação para o trabalho". Nesse sentido, torna-se importante e expressivo buscar saberes sobre tal demanda social, uma vez que à educação é atribuído o "poder" transformador da sociedade, podendo promover mudanças e renovação de paradigmas. Vale ressaltar que esse desafio também deve ser atribuído a todas as esferas da sociedade, não deixando essa missão apenas para a seara educacional.

Entende-se que a interdisciplinaridade represente um novo paradigma curricular, capaz de promover a circulação dos saberes e a desfragmentação do conhecimento, o que direciona para o desenvolvimento integral de crianças e jovens em suas múltiplas dimensões: física, psíquica, social, biológica, cultural e histórica. Desta forma, seria possível promover a integração entre as disciplinas, rompendo com a compartimentação do conhecimento, que dificulta frequentemente a compreensão da totalidade do saber, via de regra caminhando na contramão da complexidade e totalidade da natureza humana.

A ótica da interdisciplinaridade apresenta o diálogo como um caminho para reflexão e integração entre o conhecimento e a prática. Nesse sentido, esta reflexão proporcionaria a criação, o descobrimento, o desenvolvimento e o aprendizado, além do diálogo entre os sujeitos e saberes, proporcionando espaços para um pensamento coletivo, valorizando a interação e a reciprocidade. Para Fazenda (2013, p 41) "aprende-se com a interdisciplinaridade que um fato ou solução nunca é isolado, mas sim consequência da relação muitos outros". É uma maneira de contextualização dos saberes. É um caminho para alicerçar os conhecimentos aos significados da realidade dos sujeitos envolvidos no processo de aprendizagem e desenvolvimento humano. Assim, as particularidades da Interdisciplinaridade na educação básica delimitam um campo de estudos e pesquisas, justificando a necessidade de mapear as produções sobre tal temática, visando identificar a direção que tais estudos adotam.

\section{METODOLOGIA}

Refere-se a um estudo bibliográfico, caracterizado como revisão integrativa, permitindo análise de determinada temática a partir de uma amostra de produção científica, permitindo a elaboração de um panorama das pesquisas sobre tal fenômeno.

0 processo de elaboração de revisão integrativa, desta pesquisa, foi norteado por 06 (seis) etapas descritas por Souza, Silva \& Carvalho (2010):

- definição do tema e formulação da questão norteadora;

- busca da produção científica na literatura pertinente a partir de critérios de inclusão e exclusão previamente definidos;

- definição dos dados a serem extraídos dos estudos selecionados, levando-se em conta os objetivos propostos para a revisão;

- $\quad$ avaliação crítica dos artigos incluídos;

- $\quad$ interpretação e síntese dos resultados;

- $\quad$ apresentação da revisão.

Primeiramente, adotou-se como tema de estudo a interdisciplinaridade na educação básica, de modo que fossem estabelecidas as seguintes indagações: De que modo a interdisciplinaridade vem sendo estudada e pesquisada atualmente? Como vêm sendo constituídas as produções científicas relacionadas à interdisciplinaridade na educação básica? 
O levantamento dos dados bibliográficos foi realizado no mês de maio de 2017, a partir do qual buscou-se examinar artigos científicos publicados na língua portuguesa sobre o tema "Interdisciplinaridade na Educação Básica", disponibilizados nas plataformas Scientific Eletronic Library (Scielo) e Coordenação de Aperfeiçoamento de Pessoal de Nível Superior (CAPES), a fim de compreender como os caminhos da prática pedagógica interdisciplinar vêm sendo analisados, a partir da visão científico metodológica.

A fim de balizar o levantamento bibliográfico, de modo que atendesse a perspectiva deste estudo, foram criados alguns critérios de inclusão para a pesquisa, como: 1. o ano de publicação da produção acadêmica em questão, no qual foram observadas produções de artigos científicos entre os anos 2011 e 2017; 2. a área temática, de modo que foram privilegiados artigos científicos pertencentes às Ciências Humanas; 3 . o descritor condizente com a temática definida, sendo ele, a interdisciplinaridade, observada tanto em seu plano conceitual, quanto em seu desenvolvimento prático, intrínseco ou não ao fazer pedagógico. Considerou-se como critério de exclusão os artigos que não atendessem aos critérios de inclusão e os quais, após leitura dos resumos, não estavam relacionados com a educação básica.

Os resultados foram organizados descritivamente e em tabelas e gráficos, com o objetivo de promover uma melhor compreensão na identificação quantitativa das informações coletadas, possibilitando a discussão em torno desses resultados.

\section{RESULTADOS}

O levantamento bibliográfico, teve como objetivo a mensuração das publicações de artigos relacionados ao tema interdisciplinaridade na educação básica, assim para o descritor "Interdisciplinaridade", filtrando a busca a partir critérios pré-definidos, como ano de publicação, área temática e tipos de literatura, e considerando todos os índices abordados no banco de dados das plataformas Scielo e CAPES, sem contudo especificar prévia segmentação de autor, título ou resumo, foram localizados 183 (cento e oitenta e três) publicações na plataforma Scielo e 257 (duzentos e cinquenta e sete) na plataforma CAPES, totalizando quatrocentos e quarenta (440) publicações. A Tabela 1 permite visualizar melhor a evolução do período.

Tabela 1: Total de artigos científicos publicados para o descritor "interdisciplinaridade" entre 2011-17.

\begin{tabular}{|l|l|c|c|c|c|c|c|c|c|c|}
\hline \multicolumn{1}{|c|}{ Base de dados } & \multicolumn{2}{c|}{ Descritor } & 2011 & 2012 & 2013 & 2014 & 2015 & 2016 & 2017 & Total \\
\hline Scielo & Interdisciplinaridade & 24 & 40 & 16 & 37 & 34 & 26 & 06 & 183 \\
\hline CAPES & Interdisciplinaridade & 33 & 40 & 34 & 44 & 61 & 42 & 03 & 257 \\
\hline Scielo + CAPES & Interdisciplinaridade & 57 & 80 & 50 & 81 & 95 & 68 & 09 & 440 \\
\hline
\end{tabular}

Fonte: Autoras.

Em análise preliminar, foi possível perceber que a maioria das publicações disponibilizadas nas plataformas referidas eram relacionadas à área da saúde, o que suscitou uma análise mais criteriosa sobre o tema, buscando o relacionamento direto do descritor com a área da educação, abordagem que apontou para a existência de 35 (trinta e cinco) publicações, representando cerca de sete e noventa e cinco décimos percentuais (7,95\%), dos artigos presentes na primeira seleção.

Essa análise é melhor explicitada com o suporte gráfico, apresentado a seguir. 


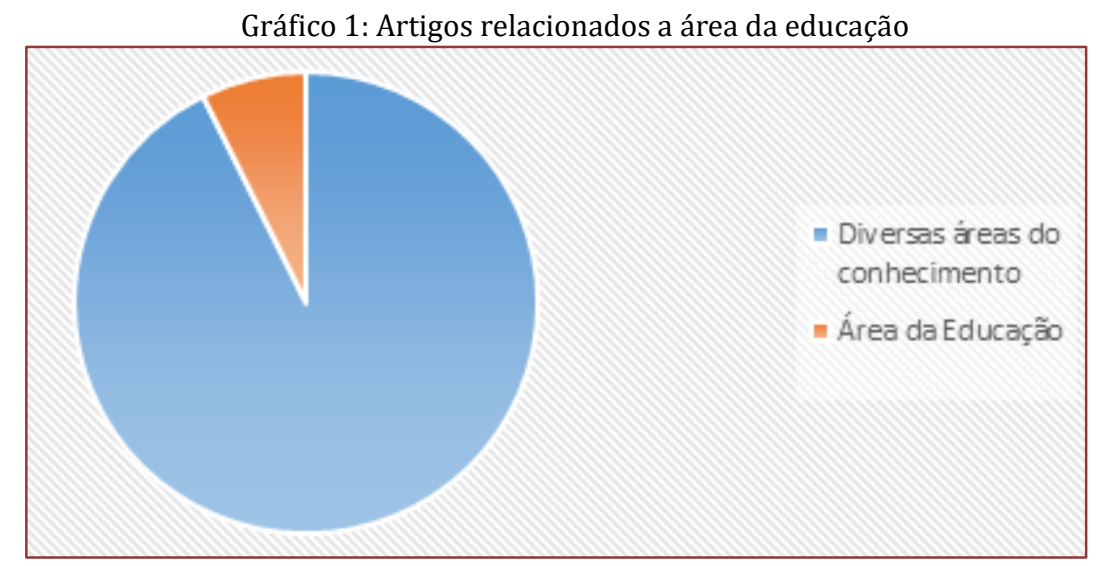

Fonte: Autoras.

Os artigos selecionados passaram por uma análise mais profícua e detalhada a partir da leitura dos resumos disponibilizados, o que fez reduzir ainda mais a seleção do material referente ao tema. Essa etapa metodológica culminou na seleção final de 12 (doze) artigos que apresentaram relação direta com a educação básica, o que representa 2,73\% (dois e setenta e três décimos) do total da primeira pesquisa, observados em acordo com os critérios pré-estabelecidos de análise e classificação dos artigos, os quais foram: 1. a "Natureza do Trabalho" (sendo o tipo de trabalho realizado); 2. o "Termo Descritor" , palavras estruturas e organizadas para facilitar o acesso às informações; 3. as "Referências" com os principais autores utilizados na pesquisa; 4. o "Objetivo" que apresenta finalidade do trabalho; 5. a "Abordagem" qualitativa ou quantitativa; 6. o "Enfoque" Compreensivo, Crítico-dialético ou Empírico-analítico; 7. o "Método" procedimentos sistemáticos e estabelecidos para realizar a pesquisa; 8. o "Resultado", com a análise e discussão dos dados coletados.

Adiante, é apresentado de maneira gráfica a dimensão dos universos pesquisados, comparando as diversas áreas de conhecimento (440 artigos no total) e aqueles ligados à educação básica (12 artigos no total).

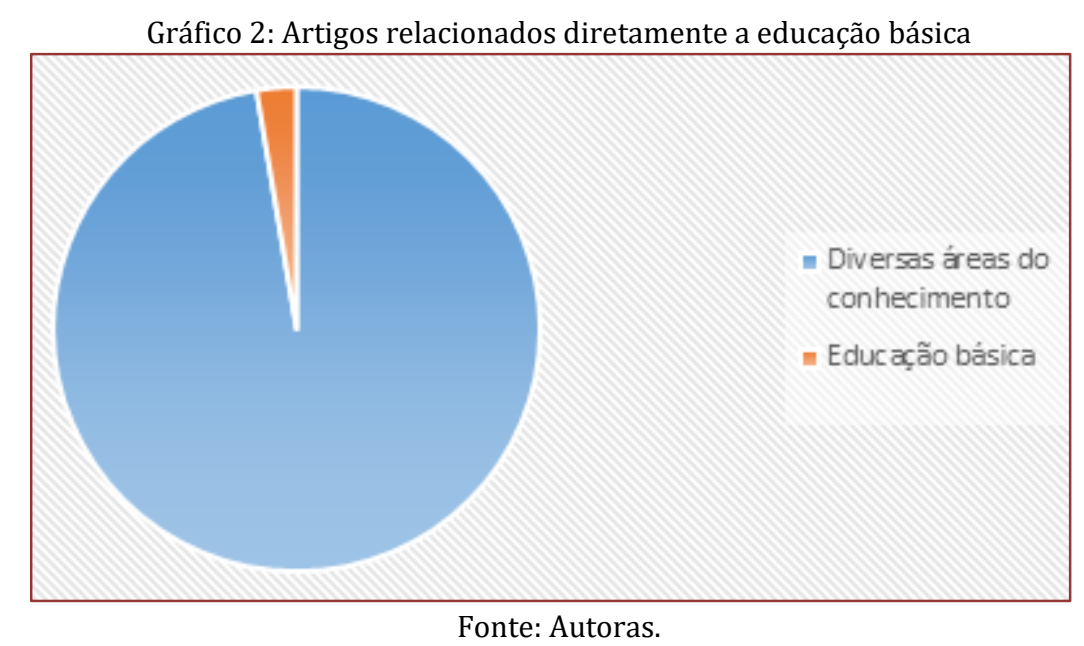

Dentre esses artigos que apresentaram conformidade com os critérios de seleção, e estão relacionados diretamente com a área da educação básica, realizou-se o levantamento dos anos de publicações e encontrou-se um cenário de escassez de publicações nos anos de 2012, 2013, 2015 e 2017.0 panorama de publicações está disposto da seguinte forma: 03 (três) publicações para o ano de 2011, quatro a menos que no ano de 2014, que contou com 07 (sete) publicações, e apenas 02 (duas) publicações em 2016. A Tabela 2 permite visualizar melhor a evolução do período. 
Tabela 2: Total de artigos científicos - Interdisciplinaridade \& educação básica entre 2011-17.

\begin{tabular}{|c|c|c|c|c|c|c|c|c|c|c|}
\hline Base de dados & \multicolumn{2}{|c|}{ Artigos selecionados } & 2011 & 2012 & 2013 & 2014 & 2015 & 2016 & 2017 & Total \\
Scielo + CAPES & $\begin{array}{c}\text { Interdisciplinaridade } \\
\text { relacionada a } \\
\text { educação básica }\end{array}$ & 03 & 00 & 00 & 07 & 00 & 02 & 00 & 12 \\
\hline
\end{tabular}

Fonte: Autoras.

Reforça-se aqui que, o presente panorama das pesquisas sobre a temática em questão, apresentou como resultado 440 (quatrocentos e quarenta) artigos, dentre os quais foram selecionados 12 (doze) que atenderam os critérios de seleção, onde inclusive há baixa ou nenhuma produtividade de trabalhos e pesquisas sobre a Interdisciplinaridade.

\section{DISCUSSÃO}

Embora o total de quatrocentos e quarenta (440) artigos encontrados sobre Interdisciplinaridade apresente-se como uma quantidade razoavelmente significativa, em sua maioria estes não abordavam questões relacionadas a área da educação, delimitando-se basicamente a área da saúde. Uma quantidade exígua das produções acadêmicas está relacionada a educação básica, o que permite observar que o tema não tem sido estudado de maneira mais abrangente.

Essa evidência, de que a Interdisciplinaridade, presente no âmbito da educação básica, tem sido discretamente pesquisada e estudada, reforça a necessidade da investigação das questões atreadas ao tema, apresentando a necessidade da realização de trabalhos científicos que desenvolvam conhecimento nesse nível de ensino, para propiciar discussões e reflexões mais profícuas.

Outro ponto a se abordar é o fato de que, se a interdisciplinaridade denota trato não isolado dos fatos, mas sim uma relação entre muitos outos fatores, como salientou Fazenda, não haveria ainda mais necessidade de se aprofundar as discussões acadêmicas a partir de uma ótica integradora, sobretudo no campo educacional, que prevê a formação integral do indivíduo? Ou seja, a escassez de trabalhos sobre a Interdisciplinaridade, entendida como um dos campos profícuos para a reintegração do conhecimento complexo, não reafirma o fato de que, o conhecimento acadêmico necessita de uma abordagem mais ampla e integrativa?

Embora esta revisão tenha se baseado em apenas duas plataformas de dados, espera-se que este panorama descrito tenha refletido parte do cenário no qual o conhecimento sobre a Interdisciplinaridade na educação básica está sendo contemplado, servindo como subsídio às pesquisas no campo da educação, sobretudo na educação básica.

\section{CONCLUSÃO}

Com base na realização desse panorama acerca das pesquisas, foi possível constatar a importância da realização de novos estudos sobre a Interdisciplinaridade presente nas práticas pedagógicas, considerando que os resultados da pesquisa apontam para um pequeno número de estudos realizados sobre o tema.

Dessa forma, observou-se a necessidade de trazer à tona os estudos e discussões sobre os conceitos, teorias e atitudes interdisciplinares no ambiente escolar para contribuir com a consolidação de práticas interdisciplinares na escola, tornando efetivo o processo de construção do conhecimento pelos estudantes.

Assim, espera-se que, conforme avancem as leituras e análises do tema, também seja possível obter maiores contribuições que auxiliem na fundamentação deste estudo, bem como no reconhecimento da Interdisciplinaridade como possibilidade de uma educação integrativa, pautada no desenvolvimento humano complexo. 


\section{REFERÊNCIAS}

[1] BRASIL. Constituição da República Federativa do Brasil (1988). Brasília: Senado Federal, Subsecretaria de Edições Técnicas, 2006. 448p.

[2] FAZENDA, I. C. A. (Coord.) Práticas interdisciplinares na escola. 13 ed. São Paulo: Cortez, 2013.

[3] JAPIASSU, H. O Sonho transdisciplinar e as razões da filosofia. Rio de Janeiro: Imago, 2006

[4] SOUZA, M. T. de; SILVA, M. D.; CARVALHO, R. de. Revisão integrativa: o que é e como fazer. Einstein, Morumbi, v. 8, n. 1, p. 102-106, 2010. Disponível em: http://pt.scribd.com/doc/56528038/A2-A2-Revisao-integrativao-que-e-e-como-fazer. Acesso em: 10 maio, 2017. 


\section{Capítulo 5}

\section{A indisciplina escolar na Educação Infantil: Desafios e possibilidades na sala de aula}

\section{Maria Madalena de Melo Feliciano}

Resumo: A indisciplina na educação infantil tem sido fonte de discussões abrangentes no meio escolar, pois se trata de um problema vivenciado cotidianamente, onde a indisciplina torna-se mais um empecilho na aprendizagem do aluno. As causas são diversas e neste sentido a família e a escola estão em constante embate atribuindo uma à outra a responsabilidade pela exibição de regras para as crianças. A presente pesquisa tem por objetivo analisar a indisciplina no contexto escolar na educação infantil. Por esse motivo foi utilizado o método de pesquisa qualitativa, em que foram utilizados questionários com perguntas objetivas, os quais foram entregue na escola para dez professores. Os resultados desta pesquisa indicaram que os professores não são valorizados nem respeitados, a ausência da família contribui para a indisciplina, e o problema da indisciplina afetar a aprendizagem dos alunos.

Palavras-chave: Indisciplina, Família, Dificuldades de aprendizagem. 


\section{INTRODUÇ̃̃O}

A etapa fundamental de ensino da Educação Infantil é o primeiro espaço escolar no qual as crianças têm seu principal contato com o meio educacional, adquirindo as primeiras noções de convivência com o coletivo. Essa elementar etapa da Educação Básica é o momento em que as crianças dão início ao seu desenvolvimento social, a expansão de suas relações, como também da vida escolar, visto que os subsídios de disciplina já começam a ser apresentadas nesta fase e os atos de indisciplina já podem começar a aparecer.

No contexto da educação Brasileira a indisciplina na educação infantil tem sido fonte de discussões abrangentes no meio escolar, pois se trata de um problema vivenciado cotidianamente, sem que se consigam soluções eficazes para soluciona-lo. Sendo um grande desafio para a instituição de ensino lidar com esse impasse, principalmente o professor que convive com essa realidade na sala de aula, onde a indisciplina torna-se mais um empecilho na aprendizagem do aluno, sendo também fonte de diversa preocupação devido à gravidade dos acontecidos.

De acordo com Garcia (2006, p.123) “A indisciplina estaria desenhando um cenário indesejável, sobretudo nas salas de aula, onde persiste disputando e conquistando um espaço considerável do currículo escolar".

Desta forma o acompanhamento da família na vida escolar do estudante nesta etapa inicial da educação básica é de suma importância, pois a família mostra-se cada vez mais alvo de contribuição para a construção da disciplina, dos principais processos motivacionais e de incentivo à aprendizagem dos alunos considerados indisciplinados na escola.

Diante do exposto, o presente estudo teve por objetivo analisar a indisciplina no contexto escolar na educação infantil. Como também identificar os principais fatores que favorecem a indisciplina escolar e verificar até que ponto a indisciplina prejudica o aprendizado e desenvolvimento do estudante.

Para fundamento do tema abordado, foi realizada uma pesquisa bibliográfica, com abordagem qualitativa, a partir de leituras de livros, artigos, teses e dissertações que ajudaram a nortear esta pesquisa, tratando sob diferentes perspectivas a questão da indisciplina na escola através da visão de teóricos como Aquino (1996), Garcia (2006), Oliveira (2005) dentre outros, por mostrar aspectos relevantes para o entendimento do tema e para o desenvolvimento deste estudo. Além disso, para dar subsídios a esta pesquisa foi feita uma pesquisa de campo acerca dessa temática.

\section{METODOLOGIA}

Este artigo é o resultado de Trabalho de Conclusão de Curso (TCC), que teve como tema de pesquisa: A indisciplina escolar na educação infantil: desafios e possibilidades na sala de aula. A pesquisa foi desenvolvida em uma escola da rede pública no Município de Monte das Gameleiras/RN, realizada com dez professoras regentes de classe, com formação em Pedagogia, sendo que três pós-graduadas.

A coleta de dados se deu a partir de um questionário, segundo Cervo et al (2007,p. 53) "forma mais usada para a coletar dados, pois possibilita medir com exatidão o que se deseja"'." Sendo assim foram elaboradas questões a partir das necessidades e dúvidas sobre o assunto, o questionário foi aplicado com os professores que atuar com esse público, sendo esta de abordagem qualitativa.

\section{REFERENCIAL TEÓRICO}

\subsection{A INDISCIPLINA NO CONTEXTO DA EDUCAÇÃO INFANTIL}

Nos últimos anos, tem sido possível perceber que a indisciplina se torna cada dia mais corriqueira nas salas de aula das escolas brasileiras. Quando nos deparamos com o tema indisciplina no espaço escolar, isso implica em avaliar acerca de diversos fatores que colaboram para tal complexidade.

O tema em questão tem sido discutido cada vez mais no cotidiano escolar e vem se tornando um desafio constante para professores que se depara com o problema. Na visão de alguns autores a indisciplina na Educação Infantil esta ligada à falta de limites no qual as crianças estariam apresentando com mais intensidade nas ultimas décadas, e que seria causa de preocupação entre pais e educadores. 
De acordo com o dicionário Aurélio: (1986, p.938) "Procedimento, ato ou dito contrário á disciplina; desobediência; desordem; rebelião." A palavra indisciplina está bastante ligada á disciplina, enquanto a primeira é entendida, pelo senso comum, como quebra de regras, desobediência, a segunda significa ordem, observância de preceitos ou normas.

Dessa forma quando falamos em indisciplina, é importante destacar a falta de respeito que há pelas regras mínimas de convivência com outras pessoas, é tão imensa que os alunos passam a se comportar de maneira violenta diante dos professores e demais colegas. Se manifestando entre as mais variadas formas, desde jogar papeizinhos no colega, conversas que atrapalham o bom andamento da aula, e vandalismo no espaço escolar.

Nessa perspectiva Aquino (1996, p.40) diz que a indisciplina é traduzida como:

"bagunça, tumulto, falta de limite, maus comportamentos, desrespeito às figuras de autoridade, etc." Esta definição de indisciplina mostra a realidade das salas de aula frequentadas por alunos de diferentes comunidades do Brasil.

Nesse sentido, a indisciplina dos alunos é algo tão antigo quanto à própria escola e tem se tornado uma reclamação inevitável entre a maioria dos educadores. Adentrando na pré-escola, a criança se depara com um conjunto de novas regras estabelecidas pelas instituições escolares, o que acaba afetando outras áreas da sua vida, como, por exemplo, sua rotina; acordar e dormir cedo, fazer as tarefas de casa, e inúmeras outras situações que a criança ainda não está acostumada.

(...) crianças precisam sim aderir a regras e estas somente podem vir de seus educadores, pais ou professores. Os „limites" implicados por estas regras não devem ser apenas interpretados no seu sentido negativo: o que não poderia ser feito ou ultrapassado. Devem também ser entendidos no seu sentindo positivo: o limite situa, dá consciência de posição ocupada dentro de algum espaço social - a família, a escola, e a sociedade como um todo. (La Taille 1996, p.9)

Conforme o autor, as regras são de grande importância para impor limites e não devem ser vistas de forma negativa, pois é através delas que as crianças aprendem o que é certo e errado. Desta forma pais e educadores são fundamentais nesta fase para ajuda-las a refletir a respeito disto, e ensinar sobre os limites.

Desde muito pequenas as crianças querem saber o porquê de tudo, fazem perguntas e vão além, querem saber como funciona, exploram tudo que esta a sua volta, e muitas vezes são surpreendidas por um não, e sem saber o motivo continua tentando fazer aquilo que não lhe explicaram ser proibido. Na verdade:

(...) as crianças de hoje em dia não tem limites, não reconhecem a autoridade, não respeitam as regras, a responsabilidade por isso é dos pais, que teriam se tornado muitos permissivos. (AQUINO, 1998, p.7).

Portanto pais e educadores devem deixar claras as regras impostas para evitar confusões na cabeça das crianças. Se hoje é possível fazer algo, amanhã o mesmo já não é permitido, sem que exista clareza a criança pode tornar-se confusa, e ainda sem limite, o que intervém em sua educação acerca da importância dos limites nessa fase inicial.

\subsection{FATORES QUE CONTRIBUEM PARA A INDISCIPLINA NO AMBIENTE ESCOLAR}

A indisciplina no contexto escolar permanece na proporção dos acontecimentos cotidianos, as preocupações de professores, pais e todos envolvidos neste processo educativo, referentes aos comportamentos escolares dos alunos, tem sido uns dos assuntos mais discutidos atualmente.

A sala de aula se tornou um local de confronto, onde os alunos dificilmente se adéquam ás regras impostas pela instituição, que contrariam os valores que eles trazem do meio externo. Nesta circunstância, o papel social da escola se perde, e as práticas educativas tornam-se ineficientes, não surtindo efeitos. 
Deste modo a indisciplina é gerada no momento em que os próprios alunos não estão preparados para estar ali e participar ativamente do processo de ensino-aprendizagem. Em diversos casos, a indisciplina vai além de uma conversa paralela, ou um objeto alheio á aula. Sendo assim, neste contexto são aceitáveis as palavras de Gentile (2002):

A indisciplina é uma das maneiras que as crianças e adolescentes têm de comunicar que algo não vai bem. Por trás de uma guerra de papel podem estar problemas psíquicos ou familiares. Ou um aviso de que o estudante não está integrado ao processo de ensino e aprendizagem (GENTILE, 2002, p. 30).

Geralmente o mau comportamento pode ser reflexo de que há algo de errado com os alunos, mas nem sempre os professores dão a devida atenção a isto. Conforme Oliveira (2005, p. 65), se o professor souber ouvir o aluno sobre suas dificuldades, pessoais ou escolares, já favorecerá em muito o relacionamento e o clima de sala de aula. No entanto, não se trata de aceitar as vontades dos educandos, mas de aproximar-se deles e conhecer suas dificuldades para desempenha melhor sua função de educador. Além disso, o problema da indisciplina na maioria das vezes é uma resposta ao autoritarismo do docente, o estudante nem sempre concorda com as exigências que são feitas em sala de aula.

Outro aspecto relevante a ser observado é a forma com que foi estabelecida: se imposta coercivamente, ou estabelecida com base em princípios democráticos. Se imposta autoritariamente, o sujeito pode não se sentir obrigado a cumpri-la, e a indisciplina pode ser um protesto em relação à autoridade. (AQUINO, 1996, p. 110).

Neste contexto, pode-se assegurar que a relação professor-aluno é repleta de desafios, desde pequenos atos indisciplinarem até agressões verbais, mas também com fatores que vão além da sala de aula, como a falta de estrutura social e muitas vezes familiar, questões que influenciam diretamente nessa relação e que em alguns momentos são pontos cruciais para o mau comportamento na escola.

Em meio a esses fatores destacar o papel da família é válido tendo em vista que muitos professores agregam a indisciplina como uma resposta do que o aluno tem no seu espaço familiar. "A desestruturação familiar, a falta de interesse dos pais em conhecer a vida escolar e até mesmo a falta de valorização pela escola onde seu filho estuda, acaba contribuindo para a indisciplina escolar". (AQUINO, 1996).

Deste modo, a ausência da família nesta fase deixa as crianças a mercê das más companhias, soltas no mundo aprendendo o que não presta, esta situação é muito comum, uma vez que inúmeras crianças vêm de uma família desestruturada, vivendo em um espaço onde não tem carinho, muitas vezes não tem com quem conversar e considera que a sua existência é mais um problema no espaço familiar. Oliveira (2005, p. 47) enfatizar que:

"A "educação oferecida" pela família reflete na relação da criança com os colegas e com os professores, podendo gerar atitudes indesejáveis na escola que culminam em desobediência, agressividade, falta de respeito perante os colegas, professores e outros."

Diante deste contexto os pais muitas vezes, sem saber como agir diante da indisciplina de seus filhos, creem que todos os problemas serão resolvidos na escola. Com medo de perder o afeto dos filhos, toleram qualquer atitude, sem compreender que esse comportamento será agravado na escola, quando o estudante precisar se adequar ás regras impostas pelos docentes.

(...) É muito comum ouvirmos dos professores a queixa de que os pais não estabelecem limites, não educam seus filhos com princípios básicos como saber se comportar e respeitar os outros, saber esperar sua vez. (VASCONCELOS, 2009, p. 240).

Nota-se que a questão da indisciplina está associada à falta de participação dos pais nas atividades escolares, dificilmente os mesmos vão à escola, como também não participam das reuniões e muito menos tomam conhecimento do comportamento dos filhos. Desta maneira, a escola e a família precisam caminhar juntas, pois uma depende da outra, e não colocar a culpa no outro, o que acaba prejudicando o aluno, ambas trabalhando juntas será mais fácil constituir soluções que possam colaborar para amenizar ou resolver o problema, não esquecendo que o aluno precisa ser prioridade de todos neste processo. 


\subsection{A INDISCIPLINA NA SALA DE AULA: UM OBSTÁCULO NO PROCESSO DE ENSINO-APRENDIZAGEM}

Os problemas de indisciplina na Educação Infantil agregam as dificuldades na alfabetização, ou seja, crianças indisciplinadas tendem a apresentar baixo rendimento e insucesso escolar, e isso pode levá-los a não fazer as tarefas escolares e a ficarem desinteressados pela instituição, provocando emoções negativas, além de problemas no desenvolvimento social e moral.

Conforme nos aponta Oliveira (2005 p. 21): Além de a indisciplina causar danos ao professor e ao processo ensino- aprendizagem, o aluno também é prejudicado pelo seu próprio comportamento: ele não aproveitará quase nada dos conteúdos ministrados durante as aulas, pois o barulho e a movimentação impedem qualquer trabalho produtivo.

Diante deste contexto o primeiro a sofrer com as consequências da indisciplina é o próprio aluno devido seu rendimento escolar fica comprometido, na medida em que a sala de aula não é mais um ambiente de adquirir conhecimentos e ter prazer, mas de conflito e medo. Por consequência disto compromete também a aprendizagem do resto da turma, já que um aluno indisciplinado geralmente rouba toda a atenção na sala de aula, tirando o foco das outras crianças.

De acordo com Garcia (2008, p. 371) "um aluno indisciplinado seria não somente aquele cujas ações rompem com as regras da escola, mas também aquele que não está desenvolvendo suas próprias possibilidades cognitivas, atitudinais e morais", considerando que o aluno indisciplinado acaba, também, prejudicando seu próprio desenvolvimento.

Dessa forma o papel da família e o meio em que o aluno esta inserido, acarretam para uma série de fatores que contribuem para a dificuldade da aprendizagem no contexto escolar, e que carece ser visto como um problema que requer uma atenção pedagógica eficiente e adequada, para que a relevância de suas ações educacionais possa produzir resultados mais eficazes na construção de uma escola melhor para todos que fazem parte do processo de ensino-aprendizagem da criança.

\section{RESULTADOS E DISCUSSÃO}

Este tópico aborda a análise dos resultados coletados a partir de uma pesquisa qualitativa, realizada com dez professoras regentes de classe, com formação em Pedagogia, sendo que três pós-graduadas, lecionando para crianças no município de Monte das Gameleiras/RN, tendo como finalidade conhecer e compreender sobre a indisciplina no meio educacional. Através dos questionários apresentados, obtiveram-se os seguintes resultados.

No primeiro gráfico 1 em relação ao o que é indisciplina mostra um percentual de $60 \%$ das professoras afirmam que a indisciplina esta relacionada a não cumprir regras impostas pela a escola, já 30\% das respondentes alegam que a indisciplina relaciona-se com a falta de respeito, e 10\% menciona como a falta de participação das aulas.

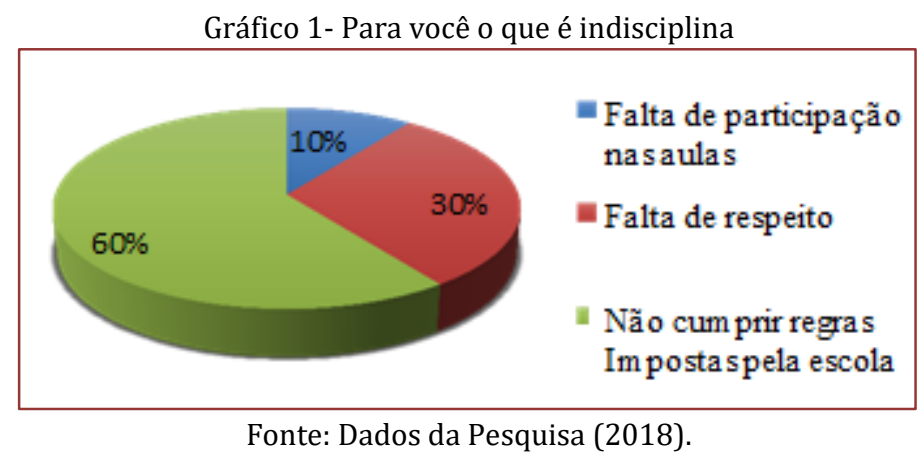

O gráfico a seguir demonstra a opinião das profissionais sobre o relacionamento professor-aluno na sala de aula. Todavia a maioria das respondentes, ou seja, 70\% afirmam que o aluno nem respeita e nem valoriza o professor, outros 30\% asseguram que há respeito mútuo entre professor e aluno. 


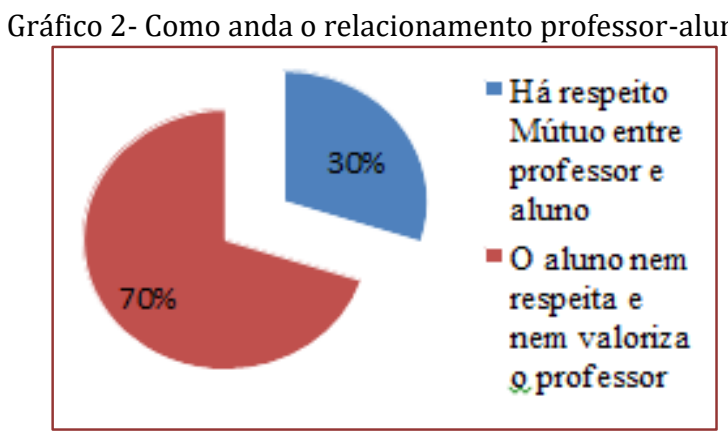

Fonte: dados da pesquisa (2018).

O Gráfico 3 expõe a opinião das professoras em relação a reação dos pais quando é chamado para tratar de questões de indisciplina dos filhos na escola. Diante disso constou-se que a maioria significativa, 60\% das profissionais afirmam que os pais reagem de forma indiferente sem saber como proceder, $30 \%$ dos pais é omissos não comparecendo a escola, e $10 \%$ colocam a culpa no professor.

Gráfico 3- Qual é a reação dos pais quando é chamado para tratar da questão da indisciplina de seus filhos

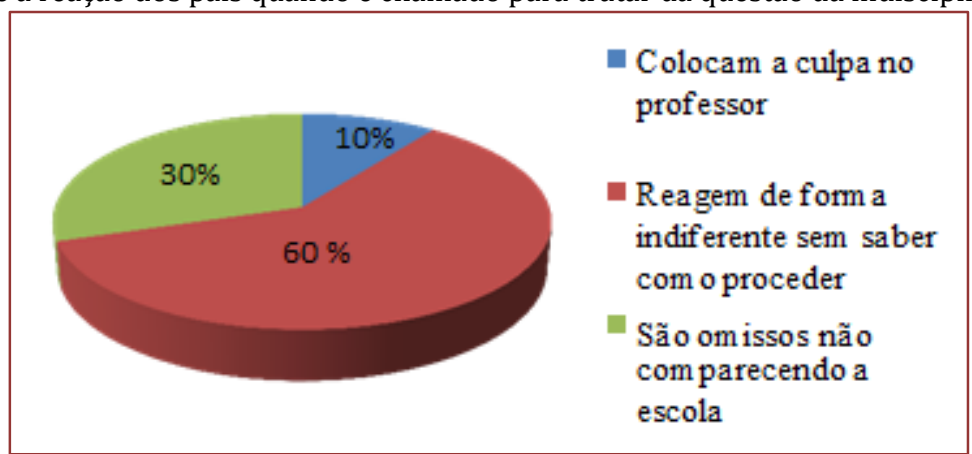

Fonte: Dados da Pesquisa (2018).

O gráfico seguinte revela a opinião das docentes sobre o que gera a indisciplina na sala de aula. Dessa forma a maior parte delas $70 \%$ afirma que o convívio familiar e social conturbado é uma das causas, já $20 \%$ das respondentes alegam o desinteresse dos alunos. Apesar disso, o restante $10 \%$ asseguram que a falta de imposição de regras como um fator contribuinte. È notório a influência que a família tem no comportamento dos filhos, tanto em sociedade como também na escola.

Desta forma a participação da família nessa fase é de grande importância para contribuir com o desenvolvimento da criança, sendo necessária a relação escola e família para promover ações eficazes que possam sanar os problemas de indisciplina e garante também a participação familiar neste contexto em prol da construção de uma educação melhor para seus filhos.

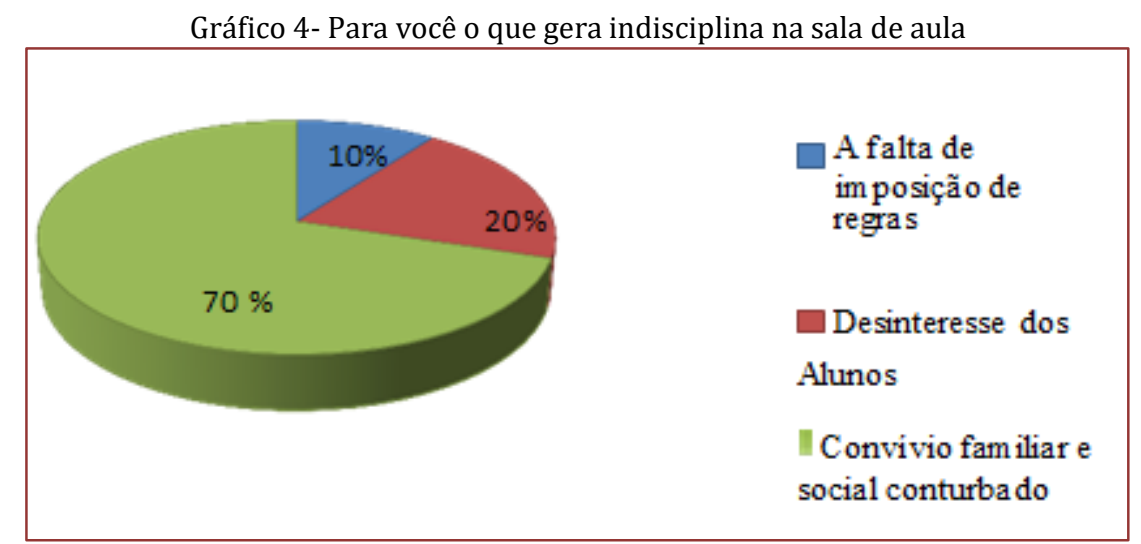

Fonte: Dados da Pesquisa (2018). 
No gráfico 5 revela a opinião das professoras faz diante de atos indisciplinarem dos alunos em sala de aula $60 \%$ dos professores afirmam que buscar conversar e chamar os pais para resolver, outros $30 \%$ conversar com os alunos buscar entendimento, e 10\% alegam conversar, chamar a direção.

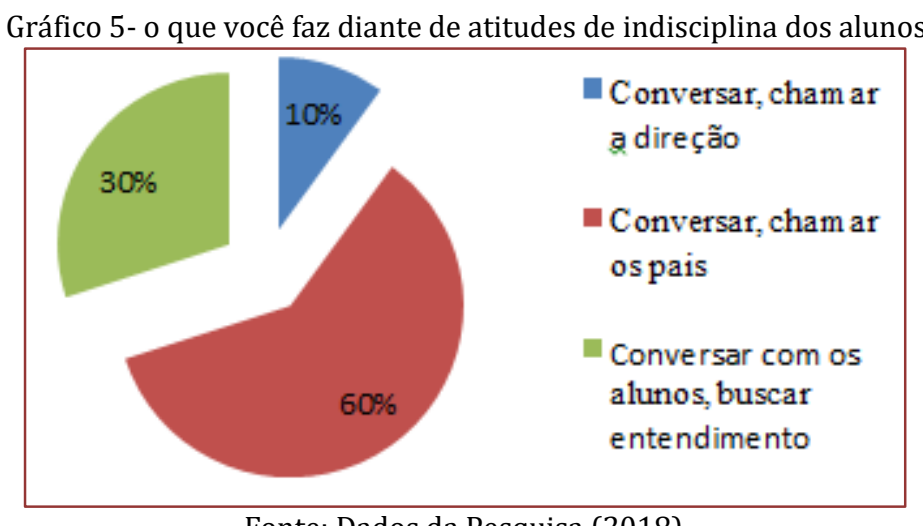

Fonte: Dados da Pesquisa (2018).

No gráfico 6 mostra a indisciplina na sala de aula sendo um fator que prejudica o aprendizado dos alunos, dessa forma é notório que $80 \%$ das professoras afirmam que sim e outros $20 \%$ das respondentes alegam que não. Desta forma, a partir dos dados coletados na pesquisa, observou-se um percentual crescente em relação a indisciplina e as dificuldades de aprendizagem das crianças.

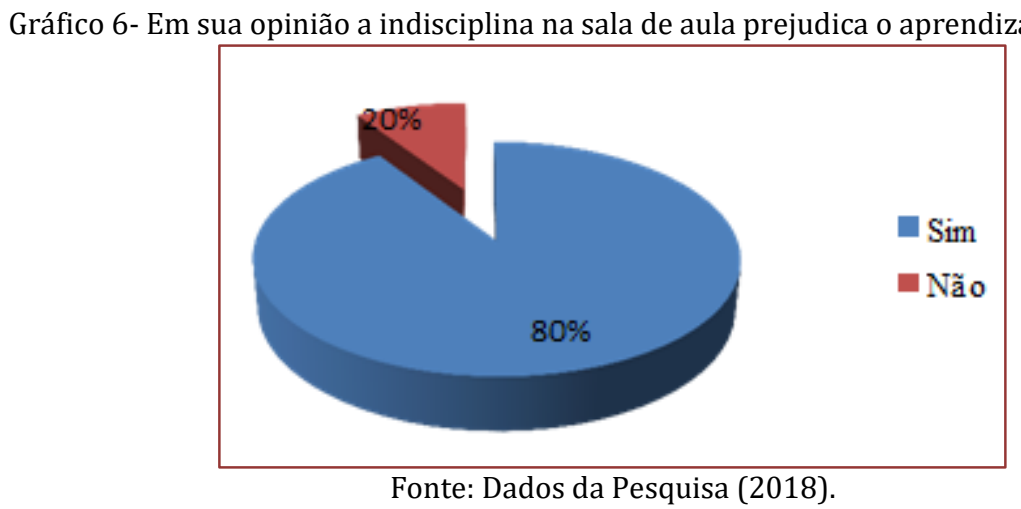

No entanto é necessário estudos mais profundos sobre o tema para melhor conhecimento dessa temática quanto a melhoria a respeito deste aspecto depende do trabalho coletivo de todos os envolvidos. Portanto a pesquisa em campo foi de suma importância para esclarecer alguns pontos referentes à indisciplina nesta fase da educação infantil, principalmente para conhecer mais sobre essa realidade no meio educacional.

\section{CONSIDERAÇÕES FINAIS}

A indisciplina na educação infantil é um tema que vem sendo discutido na sociedade de forma cotidiana entre todos os envolvidos no processo educacional, considerando que a indisciplina é um fator muito complexo, e se tornou a causa de tantas adversidades na escola como também fora dela, pode-se falar que é um problema social, já que abrange toda a comunidade.

O papel da família nesta fase é de grande importância, sendo os pais os maiores responsáveis pela educação dos filhos, se o aluno vai bem ou não na escola o motivo está na relação que este tem com a família, sobretudo se esta, que deveria ensinar-lhe desde cedo a ter respeito pelo outro, incentiva-o a levar as suas ações conforme sua vontade, sem considerar regras nem deveres estabelecidos, muitas vezes as crianças não têm uma boa base familiar e isso acaba prejudicado o seu desenvolvimento no ambiente escolar. 
É necessário que haja uma parceria entre escola e família, de um lado a família dar amor, carinho e principalmente limites, o amor da família não precisa esta relacionado com a permissividade, e do outro lado temos a escola, que atualmente deve cumprir sua função de instituição de educação dando-lhes conhecimentos teóricos e, ao mesmo tempo, ficar atenta aos sinais de indisciplina para descobrir sua causa e se possível, diminuir a frequência desta ação.

A relação família e escola devem andar juntas, visto que uma depende da outra, trabalhando unidas será mais fácil construir soluções que possam contribuir para amenizar ou resolver o problema da indisciplina não esquecendo que o aluno precisa ser prioridade de todos.

Através desta pesquisa podem-se aprimorar as informações sobre a indisciplina na educação infantil no contexto escolar e ainda conhecer um pouco mais das dificuldades enfrentadas pelos professores diante desse cenário comum na escola. Os questionários realizados foram pertinentes para complementar o que foi estudado pelos autores.

Para finalizar, considera-se que o método utilizado na pesquisa foi adequado, permitindo o alcance do objetivo. 0 resultado desta pesquisa foi satisfatório, pois revelou dados importantes no que diz respeito à indisciplina no cotidiano escolar do município estudado.

\section{REFERÊNCIAS}

[1] AQUINO, Julio Groppa. Indisciplina na escola: Alternativas teóricas e práticas. São Paulo: Summus, 1996.

[2] LA TAILLE, Yves de. A indisciplina e o sentido de vergonha. In.: AQUINO. Julio Groppa (org.) Indisciplina na escola: Alternativa teóricas e práticas. São Paulo: Sammus, 1996.

[3] AQUINO, Julio Groppa. A indisciplina e a escola atual. Ver. Fac. Educ., São Paulo, v.24 n.2, 1998. Disponível em: <http://www.Scielo.b/scielo. php?

[4] GENTILI, P. A indisciplina como aliada. Nova Escola. São Paulo, ed. 007, janeiro, 2002.

[5] OLIVEIRA, Maria Izete. A indisciplina escolar: determinações, conseqüências e ações. Brasília: líber livro, 2005.

[6] VASCONCELOS, Celso dos Santos. Os desafios da indisciplina em sala de aula e na escola. Disponível em http:// WWW.sinterroima.com.br//imagens/desafios indisciplinas 01 pag. acesso em 10/07/2020

[7] Garcia, joe. Indisciplina na escola: questões sobre mudança de paradigma. Contrapontos, itajaí, n. 3, V. 8, P. 367-380, set/dez 2008. 


\section{Capítulo 6}

\section{Pensando processos de formação para educadores(AS) da Educação Infantil}

\section{Marilei Almeida de Oliveira}

Graziela Escandiel de Lima

Resumo: Esta escrita apresenta uma reflexão acerca dos desafios do trabalho pedagógico com bebês, crianças bem pequenas e crianças pequenas, a partir das vivências e diálogos construídos no Projeto de Extensão "Trabalho Pedagógico e desafios da docência na Educação Infantil", desenvolvido durante o período de 2014 a 2016, pela Universidade Federal de Santa Maria. O projeto inseriu-se na linha de extensão "Formação de Professores" da Pró-Reitoria de Extensão dessa instituição, apresentando como objetivo a identificação e discussão dos principais desafios encontrados durante 0 desenvolvimento do trabalho pedagógico na Educação Infantil. Desse modo, a proposta de trabalho foi desenvolvida concomitante às atividades do Programa Institucional de Bolsas de Iniciação à Docência - PIBID Pedagogia/Educação Infantil. Visando uma consonância com a Política de Extensão da UFSM. 0 trabalho foi desenvolvido sob a forma de "Diálogos Pedagógicos", ou seja, o desenvolvimento do projeto aconteceu por meio de encontros mensais, nos quais acadêmicas dos Cursos de Pedagogia Licenciatura Plena - Diurno e Noturno da UFSM e professoras da Rede Municipal de ensino do município de Santa Maria/RS, atuantes na Educação Infantil, dialogaram e refletiram acerca dos principais desafios vivenciados no dia a dia da escola com crianças pequenas. Os encontros possibilitaram a identificação de tais desafios, e um processo de formação que compreende o diálogo como força que aproxima as duas esferas educacionais Universidade e Escola - em momentos formativos de reflexão e discussões sobre os elementos que compõem a docência na Educação Infantil. Visamos também a criação de referenciais de trabalho que busquem superar os desafios encontrados pelas professoras e vivenciados pelas acadêmicas nas escolas. Assim, buscaremos ao longo do trabalho discutir a Educação Infantil, a formação inicial e continuada de pedagogos(as), bem como, apresentar resultados alcançados com este processo formativo.

Palavras-chave: Desafios da Docência. Diálogos Pedagógicos. Formação de Pedagogos. 


\section{INTRODUÇÃO}

A sensibilidade e a alegria do que fazer docente são necessárias à prática pedagógica, em qualquer etapa e/ou contexto da Educação. Porém, quando falamos em Educação Infantil essa sensibilidade surge como algo indissociável, pois ao dirigirmo-nos aos aportes teóricos das Políticas Púbicas pensadas para esta etapa, entendemos que a mesma, considerada a primeira etapa da Educação Básica, tem por finalidade "[...] o desenvolvimento integral da criança de zero a cinco anos de idade em seus aspectos físico, afetivo, intelectual, linguístico e social, complementando a ação da família e da comunidade" (BRASIL, 1996). Desse modo, destacamos o quanto o ato da sensibilidade se faz necessário, a sensibilidade em estar atuando no contexto da Educação Infantil, de desenvolver o ato da escuta e da reflexão, de ser sensível às histórias de vida com as quais nos relacionamos e, principalmente, a sensibilidade para a percepção de que se está trabalhando com crianças, crianças que precisam ser crianças e gostar de sê-las, desfrutando de todas as maravilhas da infância.

Corroborando com o exposto, organizamos esta escrita a fim de apresentar as ações do Projeto de Extensão "Trabalho Pedagógico e desafios da docência na Educação Infantil"; os processos formativos vivenciados por Bolsistas de Iniciação à Docência, Iniciação Científica e Extensão, assim como por professoras $^{5}$ de Educação Infantil e da Universidade Federal de Santa Maria. Vivências possibilitadas a partir de olhares produzidos sobre o trabalho pedagógico desenvolvido em escolas de Educação Infantil da rede Municipal de Santa Maria/RS.

Nesse sentido, discutiremos alguns dados do projeto sob o ponto de vista dos encontros realizados para a formação de Professoras da Educação Infantil, analisando os principais desafios apontados pelas mesmas durante esse processo formativo.

O Projeto contou com o auxílio da Pró-Reitoria de Extensão da UFSM, inserindo-se no Programa Fundo de Incentivo à Extensão - FIEX, em suas edições de 2014 e 2015, tendo como abrangência a linha de extensão "Formação de Professores", caracterizando-se como um espaço de formação inicial e continuada, uma vez que contemplou em seus processos de organização e desenvolvimento acadêmicas dos Cursos de Pedagogia Licenciatura Plena - Diurno e Noturno da UFSM e educadoras da Rede Municipal de Santa Maria/RS, atuantes na Educação Infantil.

Compreendemos que para iniciarmos nossas reflexões se faz necessário caracterizar o trabalho pedagógico na Educação Infantil como um conhecimento ainda em construção. Sendo circunscrito no âmbito da Educação Infantil, este trabalho é adjetivado e entendido como pedagógico e envolve concepções, conceitos, organização curricular e pedagógica, perspectivas práticas e o próprio planejamento, sendo que podemos definir como um conjunto de conhecimentos necessários às professoras que atuam com bebês, crianças bem pequenas e crianças pequenas. Lima (2010) configura o trabalho pedagógico e sua materialidade na Educação Infantil, destacando elementos referenciais para a formação de pedagogos, levando-nos a compreender que essa formação precisa tematizar uma diferenciada concepção de infância, bem como infere a necessidade de promover um trabalho que tenha a criança como foco principal. 0 trabalho que ora se apresenta surge da necessidade de colaborar para processos de formação de pedagogos(as), sejam estes iniciais ou continuados.

Assim, o Projeto em tela objetivava identificar e discutir os principais desafios da docência que se apresentam no dia a dia das instituições de Educação Infantil, tendo em vista a organização de processos de formação (inicial e continuada) de professoras de Educação Infantil, visando uma consonância com a Política de Extensão da UFSM. O desenvolvimento aconteceu com vistas a discutir com as professoras os principais desafios do trabalho pedagógico na Educação Infantil em instituições públicas, sendo que a proposta foi desenvolvida concomitante às atividades do PIBID/UFSM/Pedagogia - Educação Infantil.

A fim de contemplar o objetivo geral em todas as suas instâncias, alguns objetivos específicos foram traçados, como: conhecer e problematizar o trabalho desenvolvido nas escolas participantes do PIBID/Pedagogia - Educação Infantil; efetivar estudos e produções sobre as experiências de professoras na Educação Infantil; organizar espaços formativos que congreguem acadêmicos(as) dos cursos de Pedagogia e educadores(as) da rede municipal de Santa Maria; identificar e discutir as concepções de trabalho pedagógico que permeiam o dia a dia das instituições de Educação Infantil; refletir e reelaborar as compreensões acerca das experiências empreendidas nas escolas participantes do PIBID/Pedagogia Educação Infantil e apontar aspectos relevantes sobre docência na Educação Infantil para a formação de professoras, em especial para o curso de Pedagogia. Junto a esses objetivos contávamos com grande

5 Usaremos PROFESSORAS, no feminino uma vez que as participantes, tanto as bolsistas quanto as profissionais eram mulheres. 
empenho de estudantes, que em sua maioria iniciantes no curso, transitavam pela universidade na busca de compartilhar no grupo os sonhos que tinham de viver uma formação acadêmica alicerçada em conhecimentos sólidos, advindos além das atividades de Ensino, também da Pesquisa e da Extensão.

Entendemos que "[...] não há mudança sem sonho, como não há sonho sem esperança” (FREIRE, 1996, p. 91), desse modo, movidas pelos mesmos sonhos e pelos tantos desafios que se colocaram durante nossos encontros formativos ou até mesmo durante os encontros de corredores, os quais também se constituem como formativos, apresentaremos uma breve contextualização da Educação Infantil, buscando destacar alguns resultados discutidos nesse processo formativo durante o ano de 2014 e o primeiro semestre de 2015, bem como um apanhado acerca da formação de educadores(as) no Brasil, destacando desafios, apontando possibilidades.

Nossas experiências destacam que o contexto da Educação Infantil está marcado por ações de proteção e cuidado às crianças, que muitas vezes acabam por impedir "[...] à liberdade, à espontaneidade, 0 desenvolvimento da autonomia, da criatividade e das iniciativas das crianças" (REDIN, 2013, p.13). Assim, percebemos a necessidade de revermos o trabalho pedagógico para esta etapa, necessitamos de práticas que propiciem o desenvolvimento integral das crianças, que demonstrem uma compreensão das mesmas como sujeitos histórico-sociais, que necessitam de estímulos para a construção de sua subjetividade, e, principalmente, que tenha, clareza de que as mesmas se encontram em processo de aprendizagem e pleno desenvolvimento. Compreendemos que "[...] os sonhos são projetos pelos quais se luta. Sua realização não se verifica facilmente, sem obstáculos. Implica, pelo contrário, avanços, recuos, marchas às vezes demoradas. Implica luta." (FREIRE, 1996, p. 54). Somos impulsionadas desse modo, a dialogarmos acerca de tais desafios, buscando em cooperação encontrar uma maneira de superá-los de modo a tornar as práticas pedagógicas para/com os pequenos algo prazeroso também para as professoras.

Diante disso, apresentaremos como os encontros formativos, organizados a partir da articulação entre o PIBID-CAPES-UFSM - Pedagogia/Educação Infantil e o projeto de extensão "Trabalho Pedagógico e desafios da docência na Educação Infantil", auxiliaram na formação permanente deste grupo e de tantas outras educadoras e acadêmicas que se juntaram a esta caminhada, com especial enfoque na produção e análise de um quadro com referências para o trabalho pedagógico e à docência na Educação Infantil que foram posteriormente discutidos e analisados conjuntamente com as professoras nas escolas participantes do PIBID.

Visando o desenvolvimento de processos de formação inicial e continuada, o Projeto se desenvolveu juntamente com as atividades do Programa Institucional de Bolsas de Iniciação à Docência PIBID/Pedagogia Educação Infantil. Desse modo, além das professoras atuantes nas instituições contempladas com o programa, mediante convite realizado a todas as instituições da Rede Municipal de Ensino do município de Santa Maria/RS, algumas professoras de outras unidades, atuantes na Educação Infantil, participaram dos "Diálogos Pedagógicos".

Os diálogos se caracterizam como espaços/tempos de formação, que, por meio de encontros mensais, educadoras e acadêmicas se reuniam buscando um aprofundamento teórico para as práticas desenvolvidas, refletindo sobre as mesmas e principalmente dialogando sobre os desafios encontrados no dia a dia das escolas

\section{ELEMENTOS TEÓRICOS: DISCUTINDO A EDUCAÇÃo INFANTIL E A FORMAÇÃO DE PROFESSORAS}

A Educação Infantil teve seu primeiro reconhecimento legal com a promulgação da Constituição Federal, em 1988, quando em seu Artigo 208 instituiu a mesma como dever do Estado e direito da criança (BRASIL, 1988). No ano de 1990, o Estatuto da Criança e do Adolescente reafirmou tal direito (BRASIL, 1990). Seis anos mais tarde, com a aprovação da Lei ㄲo. 9394/96, a Lei de Diretrizes e Bases da Educação Básica LDB, a Educação Infantil passou a ser considerada a primeira etapa da Educação Básica; devendo ser oferecida em creches e pré-escolas (BRASIL, 1996). Em 1998, os Referenciais Curriculares Nacionais da Educação Infantil caracterizaram a mesma como a primeira etapa da Educação Básica que tem por finalidade o desenvolvimento integral da criança, de zero até os seis anos de idade, atendendo o papel de socializadora, devendo propiciar às crianças pequenas conhecimento da realidade social e cultural (BRASIL, 1998).

No ano de 2009, a Emenda Constitucional (EC) 59/2009 tornou obrigatória a Educação Infantil para crianças a partir dos quatro anos de idade. Tal institucionalização deveria ser implantada até o ano de 2016 em todo o território nacional. Nesse sentido, com a mobilização por um projeto a longo prazo, aprovou-se em 2015, o Plano Nacional de Educação, e respectivamente, os Planos, Estadual e Municipal de 
Educação, os quais apresentam metas e estratégias a serem cumpridas dentro do decênio vigente, além disso, perecebeu-se a necessidade de um documento que olhasse para a especificidade da infância e do trabalho a ser desenvolvido nas instituições em que a Educação das crianças acontece. Desse modo, os diálogos acerca de um "currículo" comum ganharam mais força e articulação, vindo a transformar-se na Base Nacional Comum Curricular, e junto dela, o Referencial Curricular Gaúcho e os documentos orientadores curriculares municipais.

Desse modo, naquele momento, 2014 e 2015 o que nos preocupava era o surgimento de mais desafios, além dos já existentes, os quais poderiam afetar a qualidade da Educação Infantil, destacando, principalmente, a formação de professoras capacitadas para o exercício da docência com crianças pequenas. Diante disso, surgiu a necessidade de propiciar espaços/tempos formativos para e com as professoras da Educação Infantil, considerando além daquelas profissionais em exercício, as acadêmicas do Curso de Pedagogia, futuras pedagogas.

Assim, buscamos entender como esses processos formativos vêm se constituindo ao longo do tempo em nosso país. A formação inicial de professores tornou-se prioridade da Educação brasileira somente no início do século XXI, porém os cursos de licenciatura não sofreram muitas alterações nos últimos 50 anos. Sobre isso, Azevedo et al (2012), realizou estudo teórico seguindo uma perspectiva histórica-crítica, no qual aponta algumas considerações gerais acerca da formação de professores no Brasil e, principalmente, uma trajetória dessa formação. 0 referido estudo caracteriza o professor a cada década, partindo dos anos 60 até os anos 2000.

Para tanto, as discussões iniciam caracterizando os educadores da década de 60 como educadores transmissores de conhecimentos, os quais acreditavam que jamais poderiam aprender algo com seus educandos e viam o ato de educar como uma simples transmissão de conteúdos. A década seguinte foi marcada pela pedagogia tecnicista, na qual o educador foi caracterizado como o técnico da educação, que tinha uma formação voltada exclusivamente para a instrumentalização técnica. Os anos 80 foram anos de mudanças, essa década foi fortemente marcada pela pedagogia libertadora de Paulo Freire (1921-1997), na qual o educador defendeu a importância de educadores considerarem os saberes prévios dos educandos e de tomarem para si que educar não consiste em transmitir conteúdos, em suas palavras "[...] é preciso que [...] vá ficando claro que, embora diferentes entre si, quem forma se forma e re-forma ao formar e quem é formado forma-se e forma ao ser formado. [...] não há docência sem discência. (FREIRE, 2013, p. 25).

Na década seguinte, o educador já pôde ser caracterizado como o educador pesquisador, pois a relação teoria/prática passou a ser o eixo central dos cursos de formação de professores; o que possibilitou que nos anos de 2000 o educador passasse a ser caracterizado como professor pesquisador-reflexivo, para o qual a prática pedagógica é vista como espaço/tempo de reflexão e de construção de novos conhecimentos.

Levando em conta essas mudanças históricas e sociais, os cursos de Pedagogia do país devem possibilitar uma formação comprometida com os aspectos econômicos, culturais e políticos da sociedade. Propiciando a seus acadêmicos e acadêmicas a autonomia em se constituir sujeito de sua formação, além de diálogos críticos-reflexivos de modo a relacionar teoria e prática, ou seja, a formação inicial deve formar profissionais capazes de estudar, planejar, desenvolver e avaliar de forma reflexiva sua prática pedagógica.

Francisco Imbernón em seu livro "Formação Docente e Profissional: formar-se para a mudança e a incerteza" (2011), destaca que durante a formação inicial,

É preciso estabelecer um preparo que proporcione um conhecimento válido e gere uma atitude interativa e dialética que leve a valorizar a necessidade de uma atualização permanente em função das mudanças que se produzem; a criar estratégias e métodos de intervenção, cooperação, análise, reflexão; a construir um estilo rigoroso e investigativo. Aprender também a conviver com as próprias limitações e com as frustrações e condicionantes produzidos pelo entorno, já que a função docente se move em contextos sociais que, cada vez mais, refletem forças em conflito. (IMBERNÓN, 2011, p. 63-64)

Assim, compreende-se que a formação inicial se justifica pela necessidade de uma qualificação/preparação para o exercício da docência, porém a mesma não deve ser considerada algo acabado e/ou sem conexão com o contexto atual da educação. Deve ser considerada um início, um primeiro passo dessa qualificação, 
através da qual o futuro educador possa apropriar-se de conhecimentos e desenvolver formas de organização profissional que são próprias, construídas nos movimentos empreendidos nos contextos formativos dos quais participa e que, a continuidade dos processos formativos possa caracterizar-se como formação permanente e seja uma continuação da primeira.

Reconhecendo a formação inicial desenvolvida nos cursos de pedagogia como uma formação que deve ir além do caráter acadêmico e disciplinar, dando ênfase também as respostas para as novas demandas de atuação do(a) pedagogo(a), defendemos aqui a necessidade de uma formação que vise problematizar criticamente para/com o sujeito em formação, as práticas educativas a partir de pressupostos teóricos, metodológicos e epistemológicos.

Nessa perspectiva, compreendemos que a professora é a potencializadora da aprendizagem da criança, ela cria condições de aprendizagem para que as crianças construam sentido sobre si mesmas e o mundo em que vivem. Dessa forma, as relações estabelecidas com a professora e os colegas, necessitam estar pautadas em decisões democráticas e justas.

Diante disto, torna-se necessário destacar a importância do perfil profissional da professora da infância. Esta postura deve estar alinhada com uma boa formação profissional pautada na sensibilidade e empatia no trato com a infância, acolhendo os propósitos da criança e de seu grupo.

A Educação Infantil possui especificidades que precisam ser consideradas, neste sentido, Formosinho (2002) aponta que o papel das professoras da infância difere dos demais pelas suas especificidades, pelas características das crianças pequenas, globalidade, vulnerabilidade e a dependência da família e isto exige como diz a autora uma "rede de interações alargadas" em que a educadora assume vários papeis, pois: [...] De fato, o educador da criança pequena necessita de um saber fazer que, por um lado, reconheça essa "vulnerabilidade" social das crianças e, por outro, reconheça as suas competências sociopsicológicas que se manifestam desde a mais tenra idade, por exemplo suas formas precoces de comunicação. (2002, p.46)

São várias as especificidades que a professora da infância desempenha no seu dia a dia, que demanda uma série de saberes e fazeres necessários para o exercício de sua função que caracterizam a singularidade da profissão.

\section{ALGUNS APONTAMENTOS: “OS DIÁLOGOS PEDAGÓGICOS”}

0 processo de tomada de decisões que se estabelece ao realizar uma investigação exige que se saiba pensar em cada passo a ser dado. Os passos dados inicialmente foram pensados no sentido de poder olhar as escolas em que o Grupo PIBID estava inserido do ponto de vista das suas particularidades. Nesse movimento de estar nas escolas, registrar os movimentos, estabelecer diálogos com os envolvidos em cada espaço, pode-se situar o que Becker diz ser “[...] um modelo artesanal de ciência”. Nesse modelo, o autor recorre a argumentações da investigação sociológica para dizer que "[...] cada trabalhador produz as teorias e métodos necessários para o trabalho que está sendo feito” (1999, p. 12).

Na perspectiva de estar nas escolas, olhando, ouvindo, percebendo os movimentos, interpretando ações, reações e omissões que acontecem no dia a dia, foram desenvolvidos procedimentos de cunho etnográfico que auxiliaram a olhar com maior profundidade alguns aspectos de cada escola. Alguns desses procedimentos constam de livros e manuais sobre trabalhos realizados a partir da etnografia, porém, outros foram lançados em função das necessidades que se mostraram ao estar em cada escola, buscando trabalhar com suas especificidades.

A proposta do projeto desenvolvida concomitante às atividades do PIBID/Pedagogia Educação Infantil, buscou uma interlocução entre universidade e escolas, acadêmicas e professoras; de modo que ambas pudessem se tornar sujeitos co-formadores, capazes de formar ao ser formado (FREIRE, 2013), possibilitando ainda, aquilo que Libâneo (2006), chamou de intercâmbio entre a formação inicial e a formação continuada.

Nesse sentido, os encontros mensais, foram sendo organizados em forma de "Diálogos Pedagógicos", nos quais todos os sujeitos participantes puderam dizer a sua palavra, se constituindo parte do grupo e se percebendo sujeito formado/formador.

Assim, acadêmicas e professoras estiveram dialogando acerca do que fazer docente na Educação Infantil, levando-nos a muitas questões e poucas respostas, o que nos desafiou a organizar/propiciar no contexto universitário espaços/tempos formativos de reflexão, escuta, diálogos, movimentos. Essas ações demonstraram as possibilidades de se envolver professoras atuantes na Educação Infantil e acadêmicas 
dos cursos de Pedagogia da instituição, na discussão e reflexão sobre o que se tem preconizado na produção de conhecimentos da área e o que ainda se mostra carente de aprofundamento teórico no trabalho que se desenvolve nas instituições de Educação Infantil públicas.

Buscamos ao longo dos encontros, possibilitar discussões e reflexões acerca dos principais desafios vivenciados na docência na Educação Infantil, para desse modo, construir referenciais de trabalho $\mathrm{com} /$ para professoras que atuam e/ou que virão a atuar com crianças pequenas.

\section{COMPREENDENDO O PROCESSO DIALÓGICO DAS PROFESSORAS}

Com início no ano de 2014, os Diálogos Pedagógicos foram pensados visando a constituição de espaços/tempos de formação inicial e continuada de pedagogas. 0 primeiro passo desenvolvido junto às participantes do grupo foi a organização para os contatos iniciais e uma visita exploratória do grupo todo às escolas de Educação Infantil que participariam do Programa, objetivando traçar o reconhecimento dos espaços em que atuariam. A definição dos caminhos investigativos e as ações práticas a serem inicialmente empreendidas foram organizadas a partir da inserção das Bolsistas de Iniciação à Docência e do diálogo estabelecido com as Supervisoras nas reuniões do grupo.

Uma das ações iniciais do grupo nas escolas foi uma abordagem exploratória que compreendeu identificar os principais desafios/problemas educacionais na rede pública de Educação Infantil de Santa Maria/RS tendo em vista os Documentos Legais e Políticas Públicas relacionados à Educação Infantil. Dessa forma, os dados iniciais quanto a: turnos de atendimento, número de crianças, turmas, dados das professoras e equipes diretivas, dados de equipes de apoio, atividades desempenhadas, organização do trabalho, rotinas institucionais foram registrados em Protocolos por Escolas e auxiliaram na organização dos Planos de Trabalho que cada grupo de Bolsista ID organizou com o auxílio e acompanhamento das Supervisoras.

Também foram trabalhados os dados institucionais e sócio históricos de cada instituição, bem como dos PPP para conhecer o histórico básico e as origens e constituição de cada espaço que estava sendo (re)conhecido. A possibilidade de desenvolver processos formativos conjuntos realizados com professoras que estão na escola e acadêmicas do curso de Pedagogia possibilitou ao Grupo, uma tônica diferente no que diz respeito ao que se entende por ser o trabalho com as crianças pequenas e a docência nas escolas de Educação Infantil.

Diante disso, durante o primeiro ano os Diálogos Pedagógicos foram desenvolvidos com professoras de sete EMEI's - Escolas Municipais de Educação Infantil, totalizando um número de 54 professoras e ainda acadêmicas de graduação e professoras da universidade, dando ênfase as demandas trazidas pelas professoras da Educação Infantil, consideradas principais desafios na docência nesta etapa da Educação Básica.

Como o grupo nunca teve a intenção de palestrar, mas sim de partilhar experiências, dialogar sobre o que fazer docente na Educação Infantil e os desafios encontrados durante a prática, a proposta foi a de organizar um primeiro encontro abordando a seguinte temática "Educação Infantil: que espaço é este?", a partir desse primeiro momento, o grupo pôde organizar as temáticas que permeariam os próximos diálogos, dando ênfase as demandas trazidas pelas professoras.

Nesse sentido, identificaram-se pontos em comum entre as instituições, tais como, as salas de aula desestruturadas fisicamente, o grande número de alunos nas mesmas, a falta de tempo/espaço para o planejamento reflexivo, a falta de auxiliares nas turmas e a desvalorização do trabalho docente ${ }^{6}$.

Diante disso, percebemos contradições entre o que está previsto em Leis e a realidade do contexto escolar da Educação Infantil no município de Santa Maria/RS. Para tanto, o encontro seguinte abordou a seguinte temática "Olhares para a criança e a infância vivida na Educação Infantil", os diálogos voltaram-se para a criança que vive sua infância no espaço/tempo da Educação Infantil, quem é esse sujeito? Como vive sua infância? Com quais condições? Quais seus modos de apropriação do mundo que a rodeia?

Desse modo, percebendo a grande demanda em dialogar acerca de tal tema, os dois diálogos seguintes seguiram a mesma linha, destacando o quanto a escola tem um papel importante, assumindo a responsabilidade de educar essas crianças de forma integral, dando a elas um olhar atento que, talvez, não tenham em outro lugar. Além disso, a responsabilidade de respeitar a individualidade, os interesses e as necessidades de cada criança, entendendo a mesma como sujeito em desenvolvimento, que deve ser visto 
como alguém que tem opinião, mas precisa de um adulto que a oriente, enfatizando assim, também o papel do educador como mediador deste processo, apesar das condições de trabalho que lhes são oferecidas.

Ao destacar o papel do educador, nossos diálogos trouxeram os registros realizados pelas Bolsistas ID a partir de suas experiências nas escolas. Com essa abordagem, objetivamos demonstrar a importância dessa prática no processo de reflexão e análise de aspectos vivenciados nas escolas e que de alguma forma ainda não haviam sido nomeados e discutidos junto às acadêmicas, mas a sua recorrência e mal estar causado pela sucessão de ações mecanizadas junto às práticas observadas e até mesmo realizadas em parceria com as professoras nas escolas foi dando visibilidade a um enfoque necessário e rico em aprendizagens ao grupo como um todo.

\section{CONHECENDO UM QUADRO DE REFERÊNCIAS PARA A DOCÊNCIA: DIÁLOGOS COM/SOBRE O TRABALHO PEDAGÓGICO NA EDUCAÇÃO INFANTIL}

Os Diálogos Pedagógicos do ano de 2014 foram interrompidos no mês de dezembro, com a ideia de que muito ainda deveria ser (re)visto e por isso jamais poderíamos dá-los como concluídos, apenas em processo de pausa. Durante o último encontro as professoras e acadêmicas tiveram um espaço para compartilhar suas produções e (in)conclusões acerca do que foi dialogado durante o semestre.

0 recesso das escolas e também da universidade não nos impediu de continuarmos, como grupo, pensando estratégias para trazermos para nossos encontros formativos mais professoras e acadêmicas, de modo que ambas pudessem se tornar sujeitos co-formadores, constituindo assim um espaço/tempo de formação permanente para todas.

Para tanto, durante o ano de 2015, entendendo a necessidade da continuidade de tais diálogos, constituídos como encontros formativos realizados em colaboração universidade-escola, capazes de dar voz à professoras e acadêmicas, intensificamos a identificação e discussão dos desafios encontrados por professoras da Educação Infantil no desenvolvimento do trabalho pedagógico com suas turmas.

Os encontros tiveram início no mês de março e conforme o ano anterior, procuramos sentir/conhecer o grupo com o qual iríamos permanecer ao longo do ano dialogando, uma vez que ocorreram algumas substituições no contexto do Programa de Iniciação à Docência. Desse modo, as temáticas que contemplariam nossos encontros foram pensadas juntamente com esse novo grupo, as mesmas deveriam atender o seguinte: Adaptação da/na Educação Infantil; DCNEI's: desafios e possibilidades; Plano Municipal de Educação; Organização das rotinas na Educação Infantil; Espaços que dão espaços na Educação Infantil; Infância, Educação Infantil e cidadania; O trabalho pedagógico com bebês e Proposta pedagógica, currículo e prática: o cotidiano da escola. Além disso, tivemos como proposta inicial a produção de registros ao longo dos encontros, como forma de organizar com o grupo um conjunto de referências sobre o que estávamos dialogando. Isso porque acreditamos, como destaca Imbernón (2011), a formação consiste em descobrir, organizar, fundamentar, revisar e construir a teoria.

Outros conceitos e concepções foram trabalhados e se relacionam com um olhar bastante questionador acerca das atividades que compõem o trabalho pedagógico na Educação Infantil e por consequência a docência na Educação Infantil. 0 destaque nessa seção do texto será dado à análise realizada na organização e no conteúdo de um Quadro construído pelo Grupo que contempla aspectos relacionados à educação das crianças pequenas.

Esses aspectos foram identificados por meio da extração dos registros das Bolsistas de situações vividas nas escolas e foram organizados em aspectos positivos e a serem repensados nas escolas 7 . A esses aspectos nomeamos como referências, já que muitas delas poderiam se tornar um parâmetro, uma força na concepção de docência e trabalho pedagógico que se delineava dia a dia na experiência do Grupo de viver a escola8.

\footnotetext{
7 Salienta-se que esse movimento foi realizado tendo em vista as inúmeras vezes que o Grupo PIBID foi questionado por somente visualizar e buscar discutir aspectos problemáticos vistos nas escolas. Isso por que em determinado momento foi necessário demonstrar às Supervisoras alguns fatos que pareciam ser desconhecidos pela escola e que nomeamos como Aspectos que não compõem a docência na Educação Infantil.

80 termo referência é utilizado com base em LIMA (2010) no sentido de recomendação, apresentação, também se colocando com a idéia de Referencial, denotando aquilo que constitui uma referência, um parâmetro (LAROUSSE CULTURAL, 1992).
} 
Como referencial teórico e de apoio elegemos o Documento Práticas Cotidianas produzido pelo MEC, as Políticas Públicas para a Educação Infantil e a Formação de professores da Educação Infantil, as Diretrizes Curriculares Nacionais para a Educação Infantil e as Leituras realizadas pelo Grupo.

Vale ressaltar que aqui apresentaremos uma análise mais aprofundada do conteúdo do quadro, tendo em vista que trabalharemos com um fio condutor que tem nos feito debruçar mais sobre como acontece o que acontece no dia a dia da escola. Chamaremos a atenção para a incidência de uma cisão entre políticas públicas e possibilidades de organização institucional e do atendimento na Educação Infantil com qualidade.

Nesse sentido serão trazidas relações possíveis sobre os desafios do trabalho pedagógico na Educação Infantil. Essas relações foram feitas a partir das leituras e micro análises feitas naquele momento pelo grupo. Os quadros a seguir demonstram a forma como as políticas públicas têm sido desconsideradas pelos atores sociais que as deveriam ter como horizonte na implementação da oferta da Educação Infantil com qualidade.

Quadro 1: Aspectos da Organização Institucional que tensionam o Trabalho Pedagógico e a Docência na Educação Infantil

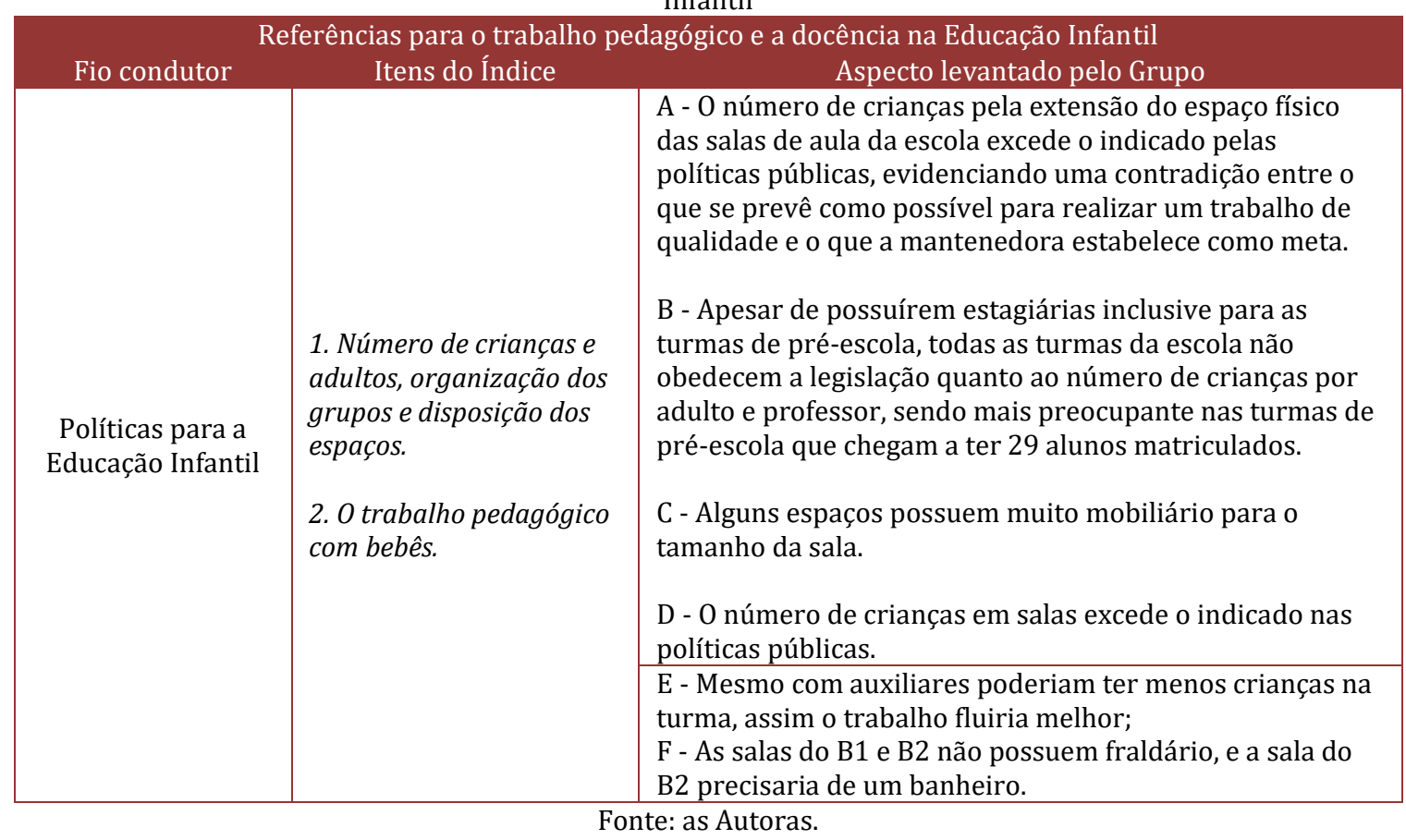

Os Parâmetros de Qualidade para a Educação Infantil, se consultados no momento de organização das turmas nas escolas poderiam configurar outras situações, diferentes das colocadas acima. Em nossas experiências nas escolas e também nos diálogos, temos visto e discutido com as professoras a dificuldade em lidar com turmas bastante numerosas. Há uma distorção de entendimento acerca da Política Municipal que rege a Educação Infantil, visto que no Artigo 22, indica-se que: "Os parâmetros para a organização de grupos de crianças deverão levar em consideração o Projeto Político Pedagógico e o espaço físico, bem como observar a relação denominação/idade, criança/adulto e criança/professor: 
Quadro 2: Aspectos da Organização Institucional que tensionam o Trabalho Pedagógico e a Docência na Educação Infantil.

\begin{tabular}{|c|l|l|}
\hline \multicolumn{2}{|c|}{$\begin{array}{c}\text { Referências para o trabalho pedagógico e a docência na Educação Infantil } \\
\text { Aspecto levantado pelo Grupo }\end{array}$} \\
\hline $\begin{array}{c}\text { Políticas para a } \\
\text { Educação Infantil }\end{array}$ & $\begin{array}{l}\text { 4 Mediação dos adultos nos diferentes } \\
\text { tempos e espaços. }\end{array}$ & $\begin{array}{l}\text { A - Em alguns momentos as estagiárias } \\
\text { substituem as professoras, reproduzem } \\
\text { alguns comportamentos inadequados e } \\
\text { executam ações mecanizadas, dando } \\
\text { somente atenção aos aspectos físicos e } \\
\text { questões relativas ao tempo. }\end{array}$ \\
& $\begin{array}{l}\text { 6. Qual o papel das Estagiárias na } \\
\text { organização do trabalho, no } \\
\text { atendimento das crianças, nas relações } \\
\text { estabelecidas? }\end{array}$ & $\begin{array}{l}\text { B - Quem recepciona as crianças são os } \\
\text { estagiários, na maioria das turmas } \\
\text { C - Em alguns momentos, algumas } \\
\text { professoras acabam ficando tão envolvidas } \\
\text { na preparação de atividades que serão feitas } \\
\text { que acabam ficando pouco tempo junto das } \\
\text { crianças. } \\
\text { D - No momento do sono quem acompanha } \\
\text { são as estagiárias. }\end{array}$ \\
&
\end{tabular}

Fonte: as Autoras.

0 destaque a ser feito remete-se à forma como a oferta de Educação Infantil é/era implementada, considerando que, no município de Santa Maria a organização se dá com grande número de crianças com um professor e muitas vezes um número excessivo de estagiários nas turmas. É importante salientar que no processo de construção do quadro, foi citado por duas Supervisoras como um ponto positivo o fato de se ter um grande número de estagiários nas escolas, no mínimo um estagiário em cada turma e um professor por turma. Advertimos no momento, que com relação ao fato de se ter muitos estagiários, poderíamos estar buscando a solução equivocada para a implementação da oferta com qualidade. Temos clareza de que ter muitos adultos frente a um grupo de crianças pode causar inclusive a dispersão de intencionalidade e a fragmentação do trabalho a ser desenvolvido. Por outro lado, o fato de estarmos em diálogo nos faz considerar que dar-se conta de determinados equívocos é um passo adiante no sentido da recondução de processos que permeiam ser professor, estar nas escolas e educar crianças com a qualidade sempre almejada.

\section{CONSIDERAÇÕES FINAIS}

Identificar os principais desafios encontrados por professoras da Educação Infantil, em sua prática pedagógica foi o objetivo desse trabalho, no entanto, apenas identificar esses desafios não irá fazer com que os mesmos deixem de existir e/ou venham a diminuir. Assim, os encontros entre acadêmicas e professoras das escolas colaboraram para que após essa identificação, ambas pudessem discutir e refletir sobre as demandas apontadas e refletidas, buscando a construção de referenciais de trabalho que auxiliassem a superar os desafios identificados na docência na primeira etapa da Educação Básica. Pois,

Como subjetividade curiosa, inteligente, interferidora na objetividade com que dialeticamente me relaciono, meu papel no mundo não é só o de quem constata o que ocorre, mas também o de quem intervém como sujeito de ocorrências. Não sou apenas objeto da história, mas sou sujeito igualmente. No mundo da história, da cultura, da política, constato não para me adaptar, mas para mudar [...] constatando, nos tornamos capazes de intervir na realidade, tarefa incomparavelmente mais complexa e geradora de novos saberes do que simplesmente a de nos adaptar a ela. (FREIRE, 2013, p. 74)

Ainda, os encontros mensais, buscaram o reconhecimento do inacabamento abordado na teoria de Paulo Freire, e desse modo, o entendimento de que estamos em constante formação, pois, "ninguém nasce feito. Vamos nos fazendo aos poucos, na prática social de que tornamos parte” (FREIRE, 2013, p. 40).

Entendemos que muito já foi feito nesse sentido, porém muito mais ainda deve ser feito, para que os desafios do trabalho pedagógico na Educação Infantil, elencados pelas professoras possam ser refletidos e superados também em outros contextos, por outros sujeitos. Para tanto, a escrita apresentada configurase igualmente como um espaço/tempo de formação inicial e continuada, propiciando por meio da reflexão crítica, espaços/tempos de estudos, leituras, denúncias, mas também de proposição e demonstração das 
possibilidades, ou seja, processos significativos de formação que nos levem a outras possibilidades de trabalho no dia a dia com as crianças nas escolas.

Nesse sentido, acreditamos que os espaços/tempos formativos precisam ser pensados como territórios de construção de saberes pedagógicos e da vida, sendo que cabe às professoras e às acadêmicas, pensar e elaborar práticas capazes de propiciar às crianças o conhecimento elaborado historicamente pela sociedade, ainda, estimulando-a para reconstruir e ressignificar esses conhecimentos. Sobre isso, Imbernón nos diz o seguinte: A formação deve apoiar-se em uma reflexão dos sujeitos sobre sua prática docente, de modo a lhes permitir examinar suas teorias implícitas, seus esquemas de funcionamento, suas atitudes etc., realizando um processo constante de auto-avaliação que oriente seu trabalho. (2011, p.55).

Ao dialogarmos com Morin (2001), podemos perceber a importância de considerarmos os aspectos físicos, psíquicos, culturais e sociais do humano.

[...] o ser humano é a um só tempo físico, biológico, psíquico, cultural, social, histórico. Esta unidade complexa da natureza... é preciso restaurála, de modo que cada um, onde quer que se encontre, tome conhecimento e consciência, ao mesmo tempo, de sua identidade complexa e de sua identidade comum a todos os outros humanos. (MORIN, 2001. p.15).

Trata-se então, de ir além, de resgatar a totalidade do humano e colaborar para que, tanto as acadêmicas em formação inicial, quanto as professoras atuantes em sala de aula se percebam sujeitos capazes de despertar também nas crianças pequenas essa totalidade humana, que sente, pensa e age.

\section{REFERÊNCIAS}

[1] AZEVEDO, Rosa 0. et al. Formação inicial de professores da educação básica no Brasil: trajetória e perspectivas. In: Rev. Diálogo Educ., Curitiba, v.12, n. 37, p. 997-1026, set./dez., 2012.

[2] BECKER, Howard. Métodos de pesquisa em ciências sociais. 4. ed. São Paulo: Hucitec, 1999.

[3] BRASIL. Constituição (1988). Constituição da República Federativa do Brasil. Brasília, DF,: Senado, 1988.

[4] __. Estatuto da Criança e do Adolescente. Brasília, 1990.

[5] ___. Senado Federal. Lei de Diretrizes e Bases da Educação Nacional: no 9394/96. Brasília, 1996.

[6] _. Ministério da Educação e do Desporto. Secretaria de Educação Fundamental. Referencial Curricular Nacional para a Educação Infantil. Brasília: MEC/SEF, 1998.

[7] FREIRE, Paulo. Pedagogia da autonomia: saberes necessários à prática educativa. 45ํo Ed. Rio de Janeiro: Paz e Terra, 2013.

[8] _ Paulo. Pedagogia da Esperança: um reencontro com a pedagogia do oprimido. 6º Ed. Rio de Janeiro: Paz e Terra, 1996.

[9] FORMOSINHO, João; OLIVEIRA-FORMOSINHO, Júlia. A universidade e a formação de educadores de infância: potencialidades e dilemas. In: MACHADO, Maria Lúcia de (org.). Encontros e Desencontros em Educação Infantil. São Paulo: Cortez, p. 169-188, 2002

[10] IMBERNÓN, Francisco. Formação Docente e Profissional: formar-se para a mudança e a incerteza. 9ํㅡ. Ed. São Paulo: Cortez, 2011.

[11] LIBÂNEO, José C. Adeus Professor, Adeus Professora? Novas exigências educacionais e profissão docente. 9o Ed. São Paulo, Cortez, 2006.

[12] LIMA, Graziela Escandiel de. Cotidiano e trabalho pedagógico na Educação de crianças pequenas: produzindo cenários para a formação de pedagogos. PUCRS: Porto Alegre, 2010. Tese (Doutorado em Educação), Faculdade de Educação, Pontifícia Universidade Católica do Rio Grande do Sul, 2010.

[13] MORIN, Edgar. Os Sete Saberes Necessários à Educação do Futuro. 3ํo ed. SP: Cortez; Brasília/DF: UNESCO, 2001.

[14] REDIN, Euclides; REDIN, Marita Martins. Porque é de infância [...] que o mundo tem precisão! Ciências \& Letras. Porto Alegre, n 43, jan/jun 2008, p. 11-24. 


\section{Capítulo 7}

\section{A creche como um direito da mãe trabalhadora}

\section{Cláudia Vianna de Melo \\ Bárbara de Oliveira Gonçalves}

Resumo: Este artigo apresenta alguns dos resultados da pesquisa de mestrado sobre a Creche Universitária da Universidade Federal Fluminense no que se refere ao movimento social das mães trabalhadoras e tem o propósito de, por meio de procedimentos metodológicos de revisão histórica e de análises descritivas, realçar o valor social e político da Creche como direito das crianças e das mães, considerando que sua reivindicação é legítima e representa uma luta histórica e política. Ressalta-se, então, a criação da Creche UFF, cuja luta se inicia nos anos 80, destacando-se a importância e a origem do Núcleo Multidisciplinar de Pesquisa, Extensão e Estudo da criança de 0 a 6 anos e o apoio da Secretaria Municipal de Educação de Niterói, RJ, que possibilitou a realização do primeiro Curso de Profissionais de Creche. Contempla-se também o valor de Projetos que ofereçam aprendizagens significativas às crianças. Conclui-se reafirmando, a partir dos dados históricos e dos Projetos da Creche UFF, a sua relevância político-social e pedagógica.

Palavras-chave: Crianças. Direitos sociais. Projetos da Creche UFF. Direitos da mãe trabalhadora. 


\section{CRECHES EM LUGARES DE TRABALHO: UMA LUTA HISTÓRICA}

Na década de 1970, intensos movimentos sociais, "liderados pelas mulheres trabalhadoras, feministas, empregadas de empresas públicas e privadas, e pelos sindicatos, [...], reivindicavam o atendimento à criança na faixa etária de 0 a 6 anos", em um espaço onde pudessem deixar suas crianças, enquanto cumpriam suas jornadas de trabalho (RAUPP, 2004, p. 201). Nesse período de luta, em que a creche representou forte apelo, passando a ser reivindicada como um direito das mulheres trabalhadoras, evocavam-se diversos dispositivos legais que tratavam do assunto. Porém, tais documentos, de acordo com Fagundes (1997, p. 77, apud RAUPP, 2004, p. 202),

Não tratam de direito à creche nos locais de trabalho, mas somente do direito da mulher trabalhadora de amamentar seu filho durante a jornada de trabalho. Ainda assim é um direito apenas da mulher, mas restrito, pois não são todas as mulheres que têm esse direito, mas aquelas que têm idade entre 16 e 40 anos e trabalham em empresas cujo número de funcionárias contratadas atinge o mínimo estipulado pela lei (30 mulheres), e somente as que amamentam. Em relação às crianças, as restrições são: somente para crianças amamentadas e até os seis meses de idade (grifos da autora).

0 direito à creche no local de trabalho, nesse contexto, passou a fazer parte, também, das reivindicações das comunidades universitárias, com a organização de empregados de empresas públicas e privadas, que levantam dados sobre as respectivas necessidades, elaboram projetos, avaliam custos e conseguem a instalação de creches.

Paulatinamente, foram sendo criadas creches nas universidades federais, alcançando o total de 26 creches instaladas em 19 de 52 Instituições Federais de Ensino Superior (IFES). Um maior número de creches surgiu em meados da década de 1980, devido à influência dos avanços da educação infantil e do crescimento da área como campo de pesquisa, que "[...] passa por significativas transformações, principalmente a partir da Constituição Federal de 1988, quando a creche passa a ser reivindicada também como um direito das crianças - até então havia sido principalmente a reivindicação de um direito da mulher trabalhadora (RAUPP, 2004, p. 203).

É somente a partir de 1986, com o Decreto no 93.408, de 10.10.198619 ${ }^{9}$, que os servidores da universidade federal, tanto mulheres quanto homens, passam a ter o direito à creche no local de trabalho. Segundo Raupp (2004, p. 203),

A partir desse dispositivo legal, a creche no local de trabalho, que até então era um direito apenas da mulher trabalhadora com idade entre 16 e 40 anos, com filhos em período de amamentação, passa a ser um direito trabalhista para os filhos de servidores de órgãos e entidades da Administração Federal e das fundações (grifos da autora).

Entretanto, apesar do esforço empreendido por professores, pesquisadores e militantes, a Constituição Federal de 1988 não contemplou como direito de servidores públicos civis e militares a assistência gratuita aos filhos e dependentes desde o nascimento até seis anos.

Nessa perspectiva, a luta pela criação de creches em local de trabalho foi, de certa forma, contida pelo Decreto no 977, de 10.11.1993210. Esse dispositivo, além de instituir o auxílio pré-escolar - assistência financeira recebida mensalmente, que visava a substituir a creche no local de trabalho -, proibia a criação de novas unidades a partir da data de sua publicação (RAUPP, 2004).

\section{CRIAÇÃO DA CRECHE UFF}

Contudo, mais três creches universitárias foram criadas após a promulgação desse decreto, provavelmente por já estarem com o processo de criação em andamento. Dentre elas, a Creche UFF:

\footnotetext{
${ }^{9}$ Dispõe sobre a instituição de creches e demais serviços de assistência pré-escolar, para os filhos de servidores dos órgãos e entidades da Administração Federal, e dá outras providências. Esse decreto foi revogado pelo Decreto no 977, de 10.09.1993.

10 Dispõe sobre a assistência pré-escolar, destinada aos dependentes dos servidores públicos da administração pública federal direta, autárquica e fundacional, desde a faixa etária de 0 a 6 anos de idade.
} 
Nasceu após 10 anos de luta em resposta ao sonho e à luta de alguns professores que abraçaram a ideia de construir um estabelecimento que oferecesse um atendimento de alta qualidade às crianças de zero a seis anos, além de constituir-se num campo de investigação e prática que possibilitasse a formação profissional e acadêmica dos estudantes de graduação e pós-graduação interessados na instância da Educação Infantil (RAUPP, 2004, p. 205).

A história de luta pela Creche UFF inicia-se, aproximadamente, em 1982, devido a demandas e mobilizações da comunidade universitária. Professores de diferentes áreas, não somente da educação, militaram por um campo de investigação e prática para a formação profissional e acadêmica de alunos de graduação e de pós-graduação e por um espaço educacional de qualidade para filhos de funcionários, professores e alunos.

Em 1987, o grupo da comunidade acadêmica, militante da criação da Creche, era constituído por professores que acompanhavam o projeto.

No ano de 1989, o reitor Hilberto de Albuquerque Jr. nomeou uma Comissão de Creche ${ }^{11}$ para acompanhamento de todo o processo, incluindo a proposta para as crianças e o projeto arquitetônico. Essa comissão gestora iniciou os trabalhos propostos e assessorava creches públicas e comunitárias de Niterói. Em meados desse mesmo ano, com a cooperação da Secretaria Municipal de Educação de Niterói, foi realizado o primeiro "Curso de Formação de Profissionais de Creche". Nascia, assim, o Núcleo Multidisciplinar de Pesquisa, Extensão e Estudo da Criança de 0 a 6 anos (NMPEEC/UFF):

[...] durante esses anos, o grupo de professores tomou para si a responsabilidade de integrar os resultados acadêmicos de diferentes áreas relativos à educação, desenvolvimento e saúde da criança de 0 a 6 anos, passando a atuar de modo mais próximo à população e à realidade de Niterói e adjacências, em espaços educacionais como creches e préescolas públicas e comunitárias (VASCONCELLOS, 2011, p. 8).

Essa atuação em espaços alternativos, dentro e fora da universidade, acontecia porque não havia um espaço físico para os estudos e pesquisas do NMPEEC. Em meados dos anos de 1990, a construção da Creche UFF foi iniciada, porém não houve continuidade na obra até 1996, quando o reitor Luiz Pedro Antunes determinou a sua retomada.

A criação da Creche UFF12, em 13 de outubro de 1997, corrobora uma história de reinvindicações e conquistas legais dos trabalhadores e pesquisadores da sociedade civil e acadêmica da época. Segundo Vera Vasconcellos (2011, p. 7):

FELICIDADE é o sentimento que brota do meu peito ao poder rememorar a história da Creche UFF. Inaugurada em outubro de 1997, demonstra as contradições e lutas aí acontecidas. Resultado de mais de dez anos de reivindicações e se situando na contramão de tendências na organização do espaço mundial (globalização, desmonte do Estado Benfeitor Welfare State -, amplos processos de privatizações), a inauguração da Creche UFF se caracterizou, sem dúvida, como um marco de resistência. Professores de diversos departamentos da Universidade Federal Fluminense se engajaram no projeto, tendo como ponto em comum a busca de um trabalho socialmente relevante, gratificante e interdisciplinar.

\footnotetext{
11 A Comissão de Creche (BS/UFF no 98 de 16.10.1989) foi constituída com os seguintes integrantes: assistentes sociais Maria da Penha (coordenadora), Tânia Flores e Jovina Barros do DAS; psicóloga Joseane Tavares de A. Silva; assistentes de administração Roseane Romão Juliano; Paulo Cezar Lara, Maria Clara Militão e Ciléia da Matta, representantes da Associação de Servidores; Mônica Neves Barret5,8 representante do Diretório Central de Estudantes (DCE) e professora doutora Vera Vasconcellos, como consultora. Fonte: site institucional.

12 A criação da Creche UFF foi formalizada no ano seguinte, com a Norma de Serviço no 488/98, que determinou que a Creche UFF fo sse vinculada administrativamente ao Gabinete do Reitor (GAR) e tecnicamente vinculada ao NMPEEC. Em junho de 1999, essa situação foi alterada pela Norma de Serviço no 499/99, que estabeleceu que a Creche não mais se subordinasse administrativamente ao GAR, mas à Pró-Reitoria de Extensão (PROEX), mantendo o vínculo com o NMPEEC, bem como os demais termos e determinações da Norma $488 / 98$. Estava assim definida a primeira configuração institucional da Creche UFF, como Programa de Extensão. Fonte: site institucional.
} 
O primeiro momento de funcionamento da Creche ${ }^{13}$, com apenas $40 \%$ das obras concluídas, foi chamado de "mutirão", porque os próprios profissionais do NMPEEC e os "estagiários avançados" se responsabilizaram pelas atividades com as crianças. As 22 crianças - filhos e filhas de professores, funcionários e alunos - eram atendidas em 10 sessões semanais de funcionamento, pela manhã, de 8 às 12 horas, e/ou à tarde, de 14 às 18 horas.

A equipe foi formada após a nomeação de uma coordenadora da unidade, por meio da Portaria no 27, de 01.06.1999, duas professoras (uma da Fundação Municipal de Educação e outra contratada pela universidade), um auxiliar de creche e de cozinha contratados e um auxiliar administrativo e um recepcionista do quadro de funcionários da universidade. A partir da Norma de Serviço no 449/99 - BS 089 de 08.06.1999, a Creche UFF ficou subordinada, administrativamente, à Pró-Reitoria de Extensão ${ }^{14}$, assim permanecendo até 2007. O NMPEEC prosseguiu no desenvolvimento de pesquisas com um grupo de professores de diferentes departamentos, dando origem ao Grupo Gestor da Creche UFF.

Em 2007, com a criação do Colégio Universitário Geraldo Reis (Resolução no 312/09) a Creche UFF tornase Departamento de Educação Infantil do COLUNI.

\section{CONTEXTO POLÍTICO}

O contexto político da Creche UFF, durante o período da pesquisa, encontrava-se mobilizado pela reconstrução do sítio institucional, pela luta por um quadro permanente de funcionários e financiamento próprio para as despesas da unidade. Em reunião da Equipe Creche UFF e famílias das crianças, em 04.06.2012, decidiu-se pela paralisação das atividades da unidade, tornando pública uma "Pauta de Reinvindicações", onde são explicitados os motivos de sua adesão à greve nacional das universidades públicas:

1 - A Creche UFF deve suspender suas atividades porque a UFF está em greve.

A Creche UFF é parte integrante da UFF. [...].

2 - A Creche UFF adere ao movimento grevista porque avalia que o momento político é especialmente propício para lutar pela continuidade da existência da Creche UFF. [...]

A precariedade das condições de funcionamento da Creche UFF coloca em risco a própria existência da Creche UFF: não é mais possível depender do esforço pessoal da equipe, para além da esperada atuação profissional responsável. [...].

Segundo ainda a Pauta de Reivindicações, a UFF firmou um convênio com a prefeitura do município de São Gonçalo, no qual a Secretaria de Educação do referido município cede um conjunto de professores para a unidade. A Creche UFF, por sua vez, responsabiliza-se pela organização e execução de um programa anual de Formação Continuada em Educação Infantil para profissionais de educação da rede escolar municipal de São Gonçalo. Tal parceria possibilitou à Creche UFF compor um trabalho com professores cedidos pela prefeitura, bolsistas e estagiários, embora não possuindo um quadro de professores concursados.

Contudo, tais professores, muitas vezes, não permanecem na unidade, ausentando-se até mesmo durante o ano letivo. São vários os fatores que têm resultado nessa dinâmica, tais como: alguns professores retornam para São Gonçalo, devido à distância entre sua residência e a unidade; outros são aprovados em concursos ou contratados por instituições particulares etc. Bolsistas e estagiários também participam da mesma dinâmica de afastamento da sala de atividades, seja devido ao término do financiamento das agências de fomento ou término de pesquisas e estágios.

Embora a dinâmica de uma unidade universitária seja a troca de bolsistas e estagiários, possibilitando diferentes formas de se construir o conhecimento na unidade, isso, na prática pedagógica, tem se configurado como um desafio para a coordenação. Essa questão era evidenciada durante as discussões das

\footnotetext{
${ }^{13}$ A localização da Creche no Campus do Gragoatá foi definida pelo Diretor do Escritório Técnico do Campus, Carlos Alberto da S. Campos. 0 projeto arquitetônico inicial teve a assinatura da arquiteta Márcia Pinheiro Extensão. Fonte: sítio institucional.

14 A Pró-Reitoria tinha a incumbência de suprir a Creche com os recursos necessários à obtenção de material permanente, de consumo e recursos humanos.
} 
reuniões de planejamento, com a constante necessidade de se reorganizar o trabalho pedagógico, resultando, muitas vezes, no fechamento de turmas inteiras ou na redução de horários de atendimento devido à falta de professores. Em virtude dessa situação, a Equipe Creche UFF reivindica "(1) concurso público para 13 professores da carreira de Ensino Básico, Técnico e Tecnológico - EBTT e (2) criação de uma matriz financeira específica para a Creche UFF, que passaria a funcionar como unidade orçamentária para suprir suas necessidades de custeio e capital".

No que se refere ao projeto político-pedagógico da unidade, ou proposta pedagógica, como é chamado na Creche UFF, seu texto é redigido em primeira pessoa do singular, como se a unidade fosse uma pessoa. A concepção de criança perpassa toda a escrita do texto, ressaltando a importância da creche como lugar dessa criança e da participação das famílias nas atividades ali desenvolvidas:

São as crianças que me colorem e me dão vida, com seus olhares curiosos, suas falas "engraçadas" e inteligentes, seus porquês de quase tudo, seus choros, risos e gargalhadas, suas brincadeiras, fantasias e correrias. São elas que com sua arte e poesia estão escrevendo a minha história. E eu me sinto muito importante para elas, pois sei que também escrevo, junto com suas famílias, pessoas e coisas que existem no mundo ao seu redor, um pouco da história de cada uma que por aqui passa. Não tenho uma criança desejada, esperada, mas muitas crianças, cada uma com seu modo peculiar de ser e de agir sobre o mundo, que me trazem desafios permanentes, rompendo com minhas certezas, impulsionandome para saber mais sobre crianças e educação. Cada vez que aguço o meu olhar e a minha escuta para esses deliciosos e enigmáticos seres que me constituem, mais eu constato que meu saber sobre eles e minha organização devem estar sempre se renovando e se recriando, para que meus corredores propiciem conexões mais significativas entre a criança e o conhecimento e para que minhas portas e janelas se abram para acolher o novo.

Na concepção de desenvolvimento infantil e aprendizagem, a brincadeira é apresentada como "um fio condutor das atividades infantis. Brincando, as crianças conhecem o mundo em que vivem e aprendem coisas importantes para a vida". As atividades realizadas com as crianças são compostas por um conjunto de brincadeiras livres, semidirigidas ou dirigidas, que podem ser combinadas nas rodinhas e, depois, reavaliadas nas reuniões pedagógicas, com a orientação das coordenadoras:

Preocupada em como propiciar este tipo de aprendizagem nas crianças, comecei a estudar a proposta de Trabalho por Projetos e a ancorar minha proposta nos princípios socioconstrutivistas, principalmente nos conceitos de equilibração majorante (PIAGET, 1976), autonomia (PIAGET, 1977) e atividade mediada (VYGOTSKY, 1988; COLE, 1997). Assim, procuro sempre criar situações interativas e desafios para as crianças.

Na proposta pedagógica manifesta-se a preocupação de como propiciar esse tipo de aprendizagem às crianças. Para alcançar tal objetivo, adotam-se os projetos temáticos, inspirados nas ideias do professor espanhol Fernando Hernández:

Nos Projetos Temáticos procuro que as crianças que aqui estão se formando pesquisem, ouçam, colaborem com os colegas, interpretem e saibam buscar a compreensão dos diversos problemas que as cercam. Em outras palavras, desejo que as crianças tenham uma relação apaixonada com a construção do conhecimento, como se ele fosse se ramificando em infinitas redes que precisamos desbravar.

Esses estudos estiveram presentes na elaboração da proposta pedagógica e continuam sendo um tema muito discutido nas reuniões de planejamento pedagógico. Para Fernando Hernández, os projetos de trabalho são como um

[...] convite a soltar a imaginação, a paixão e o risco por explorar novos caminhos que permitam que as escolas deixem de ser formadas por compartimentos fechados, faixas horárias fragmentadas, arquipélagos de docentes e passe a converter-se em uma comunidade de aprendizagem, 
onde a paixão pelo conhecimento seja a divisa e a educação de melhores cidadãos, o horizonte ao qual se dirigem (HERNÁNDEZ, 1998, p. 13).

Ainda de acordo com o contido na proposta pedagógica,

É uma alegria ver a emoção das descobertas, os artefatos produzidos e o próprio processo de andamento dos Projetos Temáticos, pois pareço estar mergulhada numa atmosfera de universidade, em que meus pequenos pesquisadores desvelam segredos e se sentem cada vez mais interessados pelas experiências, os materiais, os jogos, a leitura e a escrita, entre outros eixos de conhecimento que são abordados. É muito legal! Talvez seja por isso que as crianças estão sempre correndo, com as bochechas rosadas e a ânsia de não parar de brincar um minuto.

Portanto, ao contar a sua história constituída por "vários atores" (professores de várias áreas, estagiários, bolsistas, pesquisadores etc.), a proposta pedagógica se percebe como "resultado da ação de todos aqueles atores, aí incluídos os humanos (crianças, pais, funcionários, equipes de diferentes áreas do conhecimento) e os não humanos (brinquedos - ou sua ausência, goteiras, arranjo espacial das salas, plantas, portões etc.)"

\section{PROJETOS DE TRABALHO NA EDUCAÇÃO: UM POUCO DE HISTÓRIA}

Para a história da educação, depois da criação da escola pública burguesa o movimento escolanovista, com a proposta de mudança na maneira de pensar e repensar a escola e o currículo na prática pedagógica, foi o marco mais importante para uma sociedade em mudança, pois suas teorias valorizavam a autoformação e a atividade espontânea da criança. Segundo Barbosa e Horn (2008, p. 16),

Em geral, os escolanovistas procuravam criar formas de organização do ensino que tivessem características como a globalização dos conhecimentos, o atendimento aos interesses e necessidades dos alunos, a sua participação no processo de aprendizagem, uma nova didática e a reestruturação da escola e da sala de aula. Nessas experiências vamos encontrar várias estratégias para a organização do ensino, como os centros de interesses, os projetos e as unidades didáticas.

Dentre os educadores que mais divulgaram os ideais da escola ativa e da educação nova, o mais influente foi o filósofo e pedagogo norte-americano John Dewey, para quem a educação tem uma função social e deve promover o sujeito de forma integrada, principalmente valendo-se da arte. Dewey valorizou a experiência, propugnando uma aprendizagem pela ação (learning by doing), ou 'o aprender fazendo', defendendo uma educação que propiciasse à criança condições para que resolvesse por si própria seus problemas. Segundo ele, o pensamento se origina em situações-problema, portanto, o projeto era a procura da solução de um problema, realizada de forma efetiva, em determinado espaço e tempo, compromissada com a transformação de uma realidade.

Segundo Gadotti (2002, p. 143-144),

Para John Dewey, a experiência concreta da vida se apresentava sempre diante de problemas que a educação poderia ajudar a resolver [...] e que $\mathrm{o}$ ato de pensar mobilizado diante de um problema passaria por cinco estágios: $1^{0}-$ uma necessidade sentida; $2^{\circ}$ - a análise da dificuldade; $3^{\circ}$ as alternativas de solução do problema; 4o - a experimentação de várias soluções, até que o teste mental aprove uma delas; 5 o - a ação como a prova final para a solução proposta, que deve ser verificada de maneira científica.

Kilpatrick apoiou o seu conceito de projeto na teoria da experiência de Dewey, defendendo que as crianças adquiram experiência e conhecimento pela resolução de problemas práticos, em situações sociais. Ele destacou quatro características que concorrem para um bom projeto didático: (i) uma atividade motivada por meio de uma intenção consequente; (ii) um plano de trabalho, de preferência manual; (iii) a característica que implica uma diversidade globalizada de ensino; (iv) um ambiente natural (GADOTTI, 2002). 
No início do século XX, segundo Barbosa e Horn (2008, p. 18-19),

[...] houve várias tentativas de implementação dos projetos nas escolas americanas, mas foram encontrados dois grandes entraves. Em primeiro lugar, o fato de a concepção tradicional do programa escolar ser uma lista interminável de conteúdos obrigatórios, fragmentados, previamente definidos, uniformes e autoritariamente cobrados. Em segundo lugar, a necessidade de prever o período de duração dos projetos antes mesmo de sua execução, isto é, um controle sobre o tempo. A tentativa de superar tais dificuldades acabou gerando um novo modo de organizar o ensino, as chamadas unidades de ensino, bastante divulgadas na educação brasileira, principalmente nos cursos normais e nos livros didáticos. A consequência mais nefasta disso foi o fato de que elementos importantes da pedagogia de projetos foram esquecidos e interpretados equivocadamente.

Na opinião de Lourenço Filho (1929 apud BARBOSA; HORN, 2008, p. 19), “a proposta pedagógica de trabalho através de projetos transformou-se em uma unidade didática, controlando temas e tempos de realização, dando maior poder aos adultos na organização e na proposição das atividades".

Na década de 1970, Paulo Freire 15 nos apresenta os Temas Geradores, uma proposta de organização do ensino, onde os "conteúdos, as habilidades e as atividades dos educandos giram em torno de temas que têm relação com a realidade socioeconômica e cultural em que se insere o indivíduo" (BARBOSA; HORN, 2008, p. 19).

Nessa proposta, parte-se do estudo da realidade do educando para a organização do conhecimento. Ou seja, prioritariamente, é preciso conhecer a criança, seu ambiente, sua cultura, pois é desse contexto que devem emergir os conteúdos a serem trabalhados, que, junto às discussões, devem estar atrelados à conscientização política. A prática metodológica é estruturada com as crianças: em geral, é feita uma investigação temática, em que as crianças escolhem os temas mais relevantes para serem discutidos e a partir daí são organizados os Temas Geradores. Esses temas englobam o que se quer discutir do assunto, dentro do contexto que o gerou, levando a pesquisas e fortalecendo o senso crítico dos estudantes. Para a fase de organização do conhecimento e para auxiliar na pesquisa, os alunos colhem dados sobre o assunto, geralmente consultando a comunidade. Durante o processo há discussões em sala, com o professor auxiliando. Na fase final, acata-se a preferência da turma sobre como colocar em prática os resultados das discussões realizadas e do conhecimento construído.

Contudo, há aproximações e distanciamentos entre Projetos de Trabalho e Tema Gerador. Um dos principais aspectos que distanciam essas abordagens refere-se à aprendizagem. Os Projetos de Trabalho tentam uma aproximação da escola com o aluno e se vinculam à pesquisa sobre algo emergente, ou seja, a aprendizagem se dá por meio das relações significativas. Já com os Temas Geradores, a aprendizagem se dá através do diálogo e das trocas sociais.

\section{PROJETOS DE TRABALHO NA PERSPECTIVA DE HERNÁNDEZ}

Reorganizar o currículo por projetos, em vez das tradicionais disciplinas, é a principal proposta do educador espanhol Fernando Hernández. Ele se baseia nas ideias de John Dewey, que defendia a relação da vida com a sociedade, dos meios com os fins e da teoria com a prática. 0 projeto de trabalho objetiva a ressignificação do espaço escolar, transformando-o em um espaço vivo de interações, aberto ao real e às suas múltiplas dimensões, possibilitando uma nova perspectiva de entendimento do processo ensinoaprendizagem: Segundo Hernández e Ventura (1998, p. 61):

A proposta que inspira os projetos de trabalho está vinculada à perspectiva do conhecimento globalizado [...]. Essa modalidade de

15 Toda a sua obra é voltada para a teoria do conhecimento aplicada à educação, sustentada por uma concepção dialética em que educador educando aprendem juntos numa relação dinâmica na qual a prática, orientada pela teoria, reorienta essa teoria, num processo de constante aperfeiçoamento. Destaca-se para o pensamento pedagógico: a sua teoria dialética do conhecimento, para qual a melhor maneira de refletir é pensar e retomar a ela para transformá-la. Portanto, pensar o concreto, a realidade, e não pensar o pensamento; a categoria pedagógica da "conscientização", criada por ele, visando, através da educação, à formação da autonomia intelectual do cidadão para intervir sobre a realidade. Por isso, para ele [Paulo Freire], a educação não é neutra. É sempre um ato político (GADOTTI, 2002). 
articulação dos conhecimentos escolares é uma forma de organizar a atividade de ensino e aprendizagem, que implica considerar que tais conhecimentos não se ordenam para sua compreensão de uma forma rígida, nem em função de algumas referências disciplinares preestabelecidas ou de uma homogeneização dos alunos. A função do projeto é favorecer a criação de estratégias de organização dos conhecimentos escolares em relação a: 1) o tratamento da informação, e 2) a relação entre os diferentes conteúdos em torno de problemas ou hipóteses que facilitem aos alunos a construção de seus conhecimentos, a transformação da informação procedente dos diferentes saberes disciplinares em conhecimento próprio.

A perspectiva de Hernández não foi pensada inicialmente com especificidade para a primeira etapa da educação básica. Por isso, o autor se utiliza de termos tais como "alunos", "sala", "turma" etc., o que não invalida que suas ideias sejam aplicadas à educação infantil. Atualmente, a abordagem de projetos de trabalho proposta por Hernández está sendo adotada por diversas instituições voltadas para a educação de crianças de 0 a 5 anos, dentre as quais se inclui a Creche UFF. Tal especificidade não é pensada só para a educação infantil, mas para uma "nova versão" de projetos de trabalho, como asseguram Barbosa e Horn:

Hoje voltamos a falar de projetos, porém não da mesma forma que a Escola Nova o fez. É necessário dar-lhes "nova versão", na qual estejam incluídos o contexto sóciohistórico, e não apenas o ambiente imediato, o conhecimento das características dos grupos de alunos envolvidos, a atenção à diversidade e o enfoque em temáticas contemporâneas e pertinentes à vida das crianças (BARBOSA; HORN, 2008, p. 19; grifos das autoras).

As ideias de Hernández presentes nos projetos de trabalho passam pela globalização dos conhecimentos e pela questão da transgressão como propulsora de transformação e mudança na educação.

Nos anos de 1980, principalmente, a pesquisa sociocultural trouxe contribuições importantes para a construção de uma concepção de educação e aprendizagem resultante das interações culturais. Nessa perspectiva, a aprendizagem do indivíduo acontece por meio de trocas culturais e sociais. A escola é compreendida como um espaço propício para as interações entre alunos, professores e comunidade. A escola como geradora de cultura, e não só de aprendizagem de conteúdos, tem como necessidade ensinar e relacionar ou combinar conceitos e procedimentos.

Para Hernández (1998, p. 32),

[...] nesse contexto, o interesse e a paixão aparecem como duas virtudes fundamentais, e o desenvolvimento racional se contempla como um aspecto do pensamento, mas não como única forma de conceituar e interpretar a realidade. Os problemas para aprender e pensar não são considerados como produto de certas aptidões e de inescrutáveis processos cognitivos, e sim como complexas interações entre personalidades, interesses, contextos sociais e culturais e experiências de vida.

Noção central de sua reflexão teórico-filosófica, a globalização - a ideia de "aprender a estabelecer e interpretar relações e superar limites das disciplinas escolares” - é um convite à não divisão de conhecimentos. Mais do que propor etapas para um projeto de trabalho (índice, desenvolvimento e finalização), Hernández transgride a concepção de educação escolar vigente (inclusive na organização do espaço e do tempo), ao propor uma aprendizagem que propicie a compreensão através de questionamentos, de relacionar os conhecimentos e estabelecer trocas sociais e culturais.

\section{CONCLUSÃO}

Os projetos de trabalho desenvolvidos pelas crianças e dos professores da Creche UFF podem ampliar os cenários de aprendizagem para além do espaço da instituição e envolver pessoas da comunidade e das famílias, numa possível atuação mais efetiva da dinâmica escolar. As construções dessas histórias, a formulação das indagações e o conhecimento produzido nessa cultura escolar podem promover o diálogo 
entre pessoas comprometidas com a aprendizagem e o desenvolvimento de todas as crianças da instituição, conferindo outro sentido à infância na comunidade em que a creche e/ou pré-escola está situada. Os projetos vinculados à história de vida das crianças e de suas famílias, numa elaboração prazerosa de produção do currículo para a infância.

De acordo com a proposta pedagógica, a Creche UFF, como unidade universitária de educação infantil, tem possibilitado esse conhecimento de forma globalizada, através do desenvolvimento dos projetos de trabalho com as crianças.

Esta investigação coincidiu com o momento em que a Resolução no 1/CNE (2011) fixa as normas de funcionamento das unidades de educação infantil ligadas à Administração Pública Federal e determina que estas devem apresentar um projeto pedagógico constando os fins e objetivos da unidade educacional, bem como explicitar a concepção de criança, de desenvolvimento infantil e de aprendizagem. Sendo assim, no contexto político em que a Creche se encontra, no que se refere à Resolução no 1/2011 (BRASIL, 2011), a presente pesquisa traz elementos significativos que identificam consonância entre a proposta pedagógica da Creche UFF e a metodologia adotada apresentando a Creche UFF como um espaço de luta dos movimentos sociais e políticos em relação aos direitos da mulher trabalhadora e do direito das crianças.

\section{REFERÊNCIAS}

[1] BARBOSA, M.C.S.; HORN, M. da G.S. Projetos pedagógicos na educação infantil. Porto Alegre: Artmed, 2008.

[2] BRASIL. Ministério da Educação. Conselho Nacional de Educação. Câmara de Educação Básica. Resolução no 1, de 10 de março de 2011. Fixa normas de funcionamento das unidades de Educação Infantil ligadas à Administração Pública Federal direta, suas autarquias e fundações. Diário Oficial [da] União, Brasília, DF, 11 de março de 2011, Seção 1, p. 10.

[3] FERREIRA, I.M.S.; CANCIAN, A. (Org.). Unidades de educação infantil nas universidades federais: os caminhos percorridos. Goiânia: FUNAPE, 2009. GADOTTI, M. Histórias das ideias pedagógicas. São Paulo: Ática, 2002.

[4] HERNÁNDEZ, F. Transgressão e mudança na educação: os projetos de trabalho. Porto Alegre: Artmed, 1998. MOSS, P. Reconceituando a infância: crianças, instituições e profissionais. In: RAUPP, M.D. Creches nas universidades federais: questões, dilemas e perspectivas. Educ. Soc., Campinas, v. 25, n. 86, p. 197-217, abril 2004. Disponível em: $<$ http://www.cedes.unicamp.br>.

[5] _. Prefácio. In: COLINVAUX, D. (Org.). Cadernos creche UFF: textos de formação e prática. Niterói: EDUFF, 2011. p. 7-9. 


\section{Capítulo 8}

\section{A importância da psicomotricidade na creche}

\section{Stella Grimaldi Gomes Polito}

Vanessa Uliana Benedicto

Resumo: Para a concretização desse trabalho, realizou-se uma observação da atuação dos professores de duas escolas de Educação Infantil de um município localizado no interior do estado de São Paulo, sendo uma pertencente ao sistema público e a outra de âmbito privado. Observaram-se também o desenvolvimento dos alunos em suas respectivas etapas de desenvolvimento na faixa etária de 0 a 3 anos a quem se propõe conhecer, atentando-se à realização de atividades pedagógicas e suas práticas rotineiras 


\section{INTRODUÇÃO}

Muito se têm dito a respeito de autonomia, participação e mudança, mas, ainda são poucos os trabalhos que tratam de maneira minuciosa sobre esses processos no cotidiano da creche. No século XXI, o processo de mudança epistemológica ainda sugere a necessidade de se refletir sobre o debate filosófico entre "aparência" e "realidade".

Para elucidar esse embate, Gadotti (2001) apresenta a concepção dialética como fundamento da Educação, enquanto filosofia da práxis, ou seja, pensar a prática na perspectiva de apreensão da totalidade, na medida em que dialetizar a práxis é produzira si mesmo, descobrindo limites e desmascarando o futuro em movimento.

Desse modo, torna-se impossível pensarmos em debater sobre qualquer estrutura educativa sem antes contextualizá-la no seu aspecto histórico e social, pois o processo de análise passa, necessariamente, pela maneira como o homem, em um dado contexto, analisa sua realidade e seu mundo, percebendo-se um produtor no seu tempo e no seu espaço, um transformador objetivo da sua realidade que racionalmente analisa e modifica.

\section{REFERENCIAL TEÓRICO}

A educação é inerente ao homem, não há possibilidade de um agrupamento humano sobreviver sem a repetição dos gestos, da prática, do uso constante da língua e não se beneficiar disso. As sociedades desenvolvem processos contínuos de produção do conhecimento pelo acúmulo de informações e de conceitos, nesse sentido,

[...] o processo de produção do conhecimento deve pautar-se, sobretudo, na socialização e na democratização do saber. 0 conhecimento escolar é dinâmico e não mera simplificação do conhecimento científico, que se adequaria à faixa etária e aos interesses dos alunos. A análise do processo de produção do conhecimento escolar amplia a compreensão sobre as questões curriculares. 0 conhecimento produzido pela pesquisa parte do concreto e da prática que procede a teoria, de modo que esta só tem sentido quando articulada com aquela. 0 importante é, sobretudo, a garantia da unicidade entre teoria e prática, conhecimento geral e específico, conteúdo e forma e dimensão técnica e política. É preciso muita intencionalidade para provocar mudança no processo de produção do conhecimento. 0 conhecimento deixa de ser visto numa perspectiva estática e passa a ser enfocado como processo (VEIGA, 2004, p.46).

A educação, assim definida, pode resultar quer da ação de outrem (é a acepção primitiva e a mais geral), quer da ação do próprio ser que a adquire. É uma sequência de operações pelas quais os adultos (pais e/ou responsáveis) exercitam os jovens e favorecem o desenvolvimento de certas tendências e de certos hábitos. Quando apalavra educação é utilizada isoladamente, aplica-se, na maioria das vezes, à natureza das crianças, logo se conceitua a educação dos sentidos, isto é, os processos pelos quais as percepções construídas por intermédio das sensações se transformam, necessitam um do outro, completam-se e se organizam com o resto dos fenômenos psíquicos. Entendemos que as crianças de 0 a 3 anos de idade institucionalizadas são fruto da ação humana, ganhando materialidade no cotidiano escolar, assim como prevê a Constituição Federal de 1988, art. 208, IV, que inscreve o atendimento em creche e pré-escola às crianças de zero a cinco anos de idade entre os deveres do Estado / Poder Público para com a educação, reconhecendo, pois, a creche como instituição educativa e a LDB de 1996 define a educação infantil como primeira etapa da educação básica (Art.22), ampliando sua importância social ao integrá-la à formação comum indispensável para o exercício da cidadania. Assim, a tradução desse direito em diretrizes e normas, no âmbito da educação nacional, representa um marco histórico de grande importância para a educação infantil em nosso país marcando uma mudança em relação ao papel do Estado / Poder Público para com essa faixa etária, que deixa de ser apenas o de velar pelas crianças pequenas, conforme a Lei da Reforma de Ensino de 1971, passando a ser o de educar e cuidar, o que é reafirmado no Estatuto da Criança e do Adolescente de1990. 
A inserção da educação infantil na educação básica como sua primeira etapa é o reconhecimento de que a educação começa nos primeiros anos de vida e é essencial para o cumprimento de sua finalidade, afirmada no

Art. 29 da Lei: “a educação básica tem por finalidade desenvolver o educando, assegurar-lhe a formação comum indispensável para o exercício da cidadania e fornecer-lhes meios para progredir no trabalho e nos estudos posteriores", nos seguintes termos: Art. 29 A educação infantil, primeira etapa da educação básica, tem com finalidade 0 desenvolvimento integral da criança até os seis anos de idade, em seus aspectos físico, psicológico, intelectual e social, complementando a ação da família e da comunidade .Art. 30 A educação infantil será oferecida em: I - creches ou entidades equivalentes, para crianças de até três anos de idade; II- pré -escolas para crianças de quatro a seis anos de idade. Art. $31 \mathrm{Na}$ educação infantil a avaliação far-se-á mediante acompanhamento e registro de seu desenvolvimento, sem objetivo de promoção, mesmo para o acesso ao ensino fundamental.

Em 2013, a Lei № 12.796 apresentou alterações na LDB quanto à obrigatoriedade da educação infantil, que passa a ser exigida a partir dos 4 (quatro) anos de idade e em seu Artigo 4o indica a necessidade de considerar a criança como centro do planejamento curricular. Uma criança vista como sujeito histórico e de direitos, que constrói sua identidade pessoal e coletiva nas relações cotidianas, que "brinca, imagina, fantasia, deseja, aprende, observa, experimenta, narra, questiona e constrói sentidos sobre a natureza e a sociedade, produzindo cultura" (BRASIL, 2009) e segundo o Referencial Curricular para a Educação Infantil, aqui inclui-se a creche, o papel dessa etapa é o cuidar da criança em espaço formal, contemplando a alimentação, a limpeza e o lazer(brincar), além de educar, sempre respeitando o caráter lúdico das atividades, com ênfase no desenvolvimento integral da criança. Devem ser trabalhados os seguintes eixos: Movimento, Música, Artes Visuais, Linguagem Oral e Escrita, Matemática, Natureza e Sociedade.

Apesar do direito garantido, ainda é pequeno o número de crianças institucionalizadas em creches, comprovamos essa afirmação segundo dados do IBGE :

O Brasil chegou ao final do século XX com 96,9\% das crianças de 7a 14 anos de idade na escola. Entretanto, em 2002 apenas 36,5\%das crianças de zero a seis anos de idade frequentavam creche ou escola no país. 0 percentual ainda é menor se levarmos em conta as crianças de zero a 3 anos de idade. Destas, apenas $11,7 \%$ estão matriculadas em creche ou escola[...] Em 2010, o Brasil atendeu em creches 23,6 \%[...] a região Sudeste com a maior taxa de frequência em creches. 0 atendimento abrangeu 28,2\% dos meninos e meninas até três anos. Santa Catarina é o estado com a maior taxa, de 34,5\%, com 112.660 matrículas, número que se elevou para 120.995. Com o segundo maior percentual de crianças atendidas, São Paulo registra o maior número absoluto de matrículas, de acordo com o Censo Escolar de 2010. Foram636.793, que correspondem a 31,9\% das crianças. Em 2011, o número subiu para 761.843 matrículas na mesma faixa etária. Entre2000 e 2010, entretanto, a região CentroOeste foi a que registrou o maior aumento no número de crianças matriculadas. Na década, o atendimento subiu de 6,3\% (55.195) para 18,2\% (139.550).(BRASIL. Ministério do Planejamento, Orçamento e Gestão).

Analisando as porcentagens referenciadas pelo IBGE em relação à legislação vigente, fica claro que mesmo com o aumento de crianças institucionalizadas, a importância e reconhecimento conquistados pela creche ainda não refletem nas matrículas efetivadas, assim é imprescindível que foquemos e nos atentemos a essa etapa educacional fornecendo-lhe subsídios para demonstrar à sociedade seu caráter pedagógico e não somente aos cuidados com a alimentação e higiene, frutos de sua criação e ainda tão enraizados no século XXI. Diante desse contexto, desmistificar o caráter assistencialista torna-se nosso maior desafio, assim pensamos em legitimá-la a partir de projetos psicomotores. 
Conhecer esse ponto específico das ações educativas implica admitir a importância das experiências cotidianas dos profissionais da educação em relação ao trato com as crianças, que de acordo com Vitta et.al. Barbosa e Horn (2012) "consideram que as formas como se pensam e se processam as ações no berçário devem ser adequadas para desmistificar a dicotomia que ocorre entre o cuidar e o educar, pois todos os momentos na educação infantil podem ser pedagógicos e de cuidados". A organização pedagógica proporciona a aprendizagem e o desenvolvimento da criança na aplicação das atividades e na rotina da creche, assim tudo é atividade, desde o momento em que se pega a criança no colo em sua chegada.

Nesse sentido, pode-se pensar concretamente na creche como uma etapa especial da educação que dá direito à criança a estimulação e aprendizagem a partir das situações concretas vivenciadas no seu cotidiano escolar, portanto falar de planejamento curricular adequado à idade, intensifica o desenvolvimento e respeita a singularidade entre todos os profissionais da educação implícitos na ação em um processo participativo no qual o passo inicial é a elaboração do marco referencial, sendo esse a luz que deverá iluminar o fazer das demais etapas. A LDB 9394/96, trata Dos Profissionais da Educação. São sete artigos que estabelecem diretrizes sobre a informação e a valorização destes profissionais. Define o Art. 62 que a:

[...] formação de docentes para atuar na educação básica far-se-á em nível superior, em curso de licenciatura, de graduação plena, em universidades e institutos superiores de educação, admita para formação mínima para o exercício do magistério na educação infantil e nas quatro primeiras séries do ensino fundamental, a oferecida em nível médio, na modalidade normal.

Deve-se ainda destacar nas Disposições Transitórias, a instituição da Década da Educação, a iniciar-se um ano após a publicação da Lei e que até o fim dela "somente serão admitidos professores habilitados em nível superior ou formados por treinamento em serviço" (Art. 87§4%).

O importante é que os profissionais da educação da creche sintam-se capazes de expressar suas opiniões, de enunciar argumentos, de defender seu ponto de vista, de elucidar um parecer, de trocar experiências, de refletir a respeito de questões em comum, para se sentirem participantes do processo ensinoaprendizagem e corresponsáveis pelo acompanhamento e resultados desse processo.

Interessa aqui delinear o conceito de participação, a fim de retirarmos dele o tom vago que muitas vezes o envolve. Dizemos que participação é conquista para significar que é um processo, no sentido legítimo do termo: infindável, em constante "vir-a-ser",sempre se fazendo. Assim, participação é, em essência, autopromoção e existe enquanto conquista processual. Não existe participação suficiente, nem acabada. A participação que se imagina completa, nisto mesmo começa a regredir (DEMO, 1986,p.18 - grifo do autor).

A participação, de acordo com Demo (1986), é um processo no qual os profissionais da educação estão implicados em tudo o que ocorre na creche e a sua volta, possibilitando a vivência e o engajamento de todos com objetivos em comum para melhorar o ambiente escolar, legitimando-o e democratizando-o.

0 trabalho docente com crianças de 0 a 3 anos de idade, nesse sentido, configura-se como espaço de comunicação no qual o profissional, na resolução dos problemas cotidianos de seu saber-fazer nesta constituição social, desenvolve ações planejadas, que se apresentam como respostas aos desafios impostos pela prática. Essas ações estão alicerçadas na criativa articulação dos diferentes saberes docentes (préprofissionais, da formação, da trajetória profissional, dentre outros), identificando-se com uma educação para a cidadania, que contribua para a inserção crítica e criativa dos indivíduos na sociedade. Concebe a creche como lugar de trabalho, a criança e o professor como cidadãos, sujeitos ativos, cooperativos e responsáveis (KRAMER, 1993).

Nesse contexto a criança também adquire autonomia na modulação da presença do adulto (ao se reconhecer, reconhecer seus pertences e o dos outros, idas e vindas ao refeitório e ao banheiro, entre outras situações rotineiras), estabelecendo uma identidade segura e confiante, não só racional, mas também como um sentimento sobre si mesmo e de suas relações com o outro, identificando o que pode ou não fazer, suas potencialidades e seus limites. Constrói sua autoestima, sua autoconfiança, suas realizaçõ es são incentivadas com festejos e saudações sentindo-se estimulada em relacionar-se com os outros. Bakhtin nos ajuda a pensar que nesse olhar do outro, na posição que o outro ocupa em relação a ela forma sua identidade, seu eu (1993). 
Piaget (1975) destaca como sendo de grande valia a fase sensória motora, também conhecida por etapa do corpo vivido, para o desenvolvimento cognitivo antes do desenvolvimento da oralidade. Nessa fase a criança possui uma intensa necessidade de movimentos pelos quais vai conhecendo seu próprio corpo e tudo o que a rodeia, pela espontaneidade de seus gestos e por sua curiosidade aflorada, ajustando suas ações às explorações do meio, ampliando seu conhecimento de mundo; há também uma busca corporal para que a criança realize o conhecimento de seus limites e capacidades motoras para que possa desenvolver-se com independência e liberdade de suas ações, ou seja, o berçário está relacionado ao movimento, preparando o indivíduo para ingressar nas próximas etapas educacionais com mais segurança e destreza corporal.

Os três primeiros anos de vida da criança são importantes para que ela possa adquirir aquisições de conhecimento do próprio corpo, influenciando fortemente o processo de aprendizagem, sendo que a base psicomotora escolar atua preventivamente no desenvolvimento integral do indivíduo, considerando várias etapas de seu crescimento proporcionando noções básicas para seu desenvolvimento intelectual. A constituição de técnicas educativas pelo movimento e não apenas pelo verbal são insubstituíveis e leva acriança a resolver problemas corriqueiros da idade. Experiências de ação e movimento são introduzidas e aplicadas através de trabalhos de estimulações motrizes lúdicas, visando o desenvolvimento completo da criança.

Para o francês Henry Wallon (1968), a motricidade é um instrumento de comunicação, pois, a criança que ainda não desenvolveu a oralidade é capaz de comunicar-se através de seus movimentos expressando-se afetivamente e com empatia.

Levin (2002), psicomotricista argentino, tem trazido grandes contribuições com suas pesquisas à atualidade, afirmando que o movimento é indispensável no processo de aprendizagem. Relata ainda que o corpo e os gestos sejam de grande valia para a construção do ser humano, pois, é preciso descobrir o mundo, o ambiente que o cerca através dos movimentos, quando bem aplicada na infância garantirá subsídios para a formação de um adulto bem resolvido, pois, mesmo inconscientemente os movimentos são saberes adquiridos, que com habilidades podem ser colocados em práticas em momentos corriqueiros de trabalho ou eventuais problemas cotidianos, liberando acriatividade das ações.

Em seus relatos Le Boulch (1988) afirma que a psicomotricidade é um antecedente necessário para o desenvolvimento da escrita e da leitura:

[...] antes que a criança aprenda a ler, isto é, antes de sua entrada no curso preparatório, o trabalho psicomotor terá como objetivo proporcionar-lhe uma motricidade espontânea, coordenada eritmica, que será o melhor aval para evitar problemas de disgrafia(LE BOULCH, 1988, p. 33).

Segundo Fonseca (2008), as atividades psicomotoras agem de maneira a prevenir os problemas que tenham relação com a alfabetização.

Na creche há uma busca corporal para que a criança realize o conhecimento de seus limites e capacidades motoras para que o educando possa desenvolver-se com independência e liberdade de suas ações, ou seja, a creche está relacionada ao movimento, preparando o indivíduo para ingressar nas próximas etapas educacionais com mais segurança e destreza corporal. Estímulos de coordenação motora fina são trabalhados com a expectativa de reflexos positivos na escrita. Estudos e pesquisas demonstram que a educação psicomotora ajuda a evitar problemas futuros de concentração, confusão de letras, dificuldades na escrita e outros fatores que possam atrapalhar o rendimento da criança dentro do processo educacional, evidenciando que ao haver dificuldades de aprendizagem, em grande parte, o problema está relacionado comas bases do desenvolvimento psicomotor.

Assim, as contribuições para o desenvolvimento motor e cognitivo na aprendizagem são fundamentais, pois a estimulação motora aplicada desde muito cedo ainda em bebês leva ao desenvolvimento sensitivo corporal, trazendo à criança o prazer através do toque, o autocontrole de movimentos e a formação de um indivíduo mais Seguro, o que constituirá a base de seu desenvolvimento. Ficou claramente compreendido que a estimulação motora fina aliada a coordenação óculo manual devem ser baseados dentro da trajetória da creche, aprimorando em forma de aprendizagem o conhecimento do corpo através de seus movimentos coordenados com seus pensamentos. 


\section{METODOLOGIA}

Para a concretização desse trabalho, realizou-se uma observação da atuação dos professores de duas escolas de Educação Infantil de um município localizado no interior do estado de São Paulo, sendo uma pertencente ao sistema público e a outra de âmbito privado. Observaram-se também o desenvolvimento dos alunos em suas respectivas etapas de desenvolvimento na faixa etária de 0 a 3 anos a quem se propõe conhecer, atentando-se à realização de atividades pedagógicas e suas práticas rotineiras.

Ficticiamente a escola particular será mencionada como "Sementes do Amanhã" e a escola pública como "Brincar é Viver".

\section{RESULTADOS}

Na escola "Sementes do Amanhã", a aplicação de atividades pedagógicas no Berçário são introduzidas através de projetos. Existe nessa fase um projeto específico para se trabalhar a coordenação motora fina, intitulado "Preensão". Esse projeto valorizao processo de desenvolvimento e ampliação do conhecimento de mundo através das mãos. A faixa etária da sala é de 3 a 15 meses de idade aproximadamente, sendo que a passagem para a próxima fase depende não da idade, mas sim de que a criança tenha alcançado todos os objetivos propostos para o Berçário (cognitivo, emocional, mastigação, coordenação motora ampla, coordenação motora fina e comunicação).

Há um objetivo para cada ponto citado, sendo o da coordenação motora fina, o movimento de pinça. Nesse local, as crianças são estimuladas, não forçadas; cada bebê tem o seu tempo e como são avaliadas de maneira global, nada impede que crianças precoces passem para a próxima fase com 11 meses ou outras com 18 meses, caso comum entre bebês que nasceram prematuramente.

Esse projeto traz em sua justificativa a preparação da criança para a pinça trípudenas próximas etapas do processo educacional, visando à obtenção de destreza e precisão ao segurar um lápis futuramente. As atividades são diárias e há muita ludicidade em suas aplicações. Entre alguns dos objetivos desse projeto estão: ampliar o controle sobre o próprio corpo; aperfeiçoar habilidades manuais; desenvolver autonomia e independência; manipular objetos; estimular movimentos de preensão; perceber sensações táteis; propiciar a observação, a exploração e a interação com o objeto. As atividades são baseadas em movimentos de amassar, rasgar, folhear, puxar, desencaixar, empilhar, entre outros.

Paralelos ao projeto, são realizados estimulações que fazem parte da rotina diária e visam à independência do educando como segurar a mamadeira sem ajuda, carregar a própria lancheira, alimentar-se sozinhos com frutas, biscoitos e bolachas que são colocadas sobre o cadeirão. Possuem um tempo livre de contato com os brinquedos, onde são observados não somente sua socialização, mas como brincar, como manusear e explorar um determinado brinquedo, há uma grande euforia de toda equipe (professora e auxiliares) que comemoram cada conquista observada, como por exemplo, a independência do dedo indicador dos demais dedos da mão ao colocá-lo esticado em um orifício do brinquedo ou um movimento de pinça ainda com dificuldade, tentando arrancar o nariz de um ursinho. A cada demonstração evolutiva, a criança recebe elogios que valorizam sua autoestima. Todas as atividades são fotografadas e ao final do projeto os pais são chamados para uma apresentação, onde podem conhecer o projeto desenvolvido.

Através de uma exibição de slides, a professora discorre detalhadamente Os objetivos de cada atividade, conseguindo a atenção dos pais que demonstram muito interesse, pois detalhes pequenos passam despercebidos por eles que ficam felizes ao identificar certas ações dos filhos.

Ao final da apresentação, os pais recebem uma avaliação do filho (a) referente ao seu comportamento e desenvolvimento dentro do projeto e deixam com a coordenadora pedagógica da escola um pen drive no qual serão colocadas todas as fotos do filho em atividade.

A sala é composta por 14 alunos, uma professora, 4 auxiliares e uma faxineira o que proporciona o cuidado e a higienização de uma forma tranquila e organizada, garantindo tempo para a aplicação do projeto e estimulações individuais.

A próxima fase recebe o nome de Infantil e caminha da mesma maneira que o Berçário, através de projetos, dando continuidade ao trabalho realizado na fase anterior. Essa sala possui 26 crianças, uma professora e 7 auxiliares.

Uma prática introduzida nas ações rotineiras dessa classe é o uso da colher, trabalhando a independência de suas ações. A fase posterior recebe o nome de Fase 1, na qual se trabalha com o material proposto pelo sistema de ensino que a unidade representa; atividades de coordenação motora fina são aplicadas 
diariamente. Nessa fase, a criança consegue utilizar com destreza a pinça trípude, folhear livros uma página por vez, rasgar papel crepom e enrolar bolinhas com ele. Em suas rotinas diárias vão desenvolvendo habilidades para colocarem os calçados sozinhos, inclusive destrezas com velcros e fivelas, além de abaixarem e subirem a bermuda sem ajuda mesmo que o elástico às vezes enrole.

O Berçário da escola pública "Brincar é Viver" trabalha de uma maneira diferente, são realizados apenas 2 projetos anuais que são trabalhados aspectos globais do desenvolvimento, não havendo um projeto específico para coordenação motora fina, a equipe recebe um tema proposto pelo Departamento de Educação do município e possuem liberdade para criar e desenvolver as atividades a serem aplicadas; há um prazo para entrega, as atividades são registradas com fotos e manuscritos, ficam em exposição para os pais e comunidade. A sala atende 17 bebês, possui uma professora e uma ADI (auxiliar de desenvolvimento infantil), o que dificulta a divisão de tempo para a realização das atividades, principalmente em período que há crianças em adaptação.

Pela pouca idade, a turma necessita de tempo para cuidados, o que faz da professora e da sua auxiliar verdadeiras guerreiras dividindo o tempo entre o cuidar, o brincar e o educar. Atividades de coordenação motora fina são aplicadas duas vezes por semana. São utilizadas pequenas bolas que deslizam como se movimentassem um rolo de pão, puxam tecidos e tentam pegar um ratinho de brinquedo com o movimento de pinça. Aos 5 meses, é iniciado o trabalho com chocalhos e estímulos para segurarem a mamadeira com independência, que é conquistada ao $6^{0}$ mês, quando acontece a descoberta das mãos que observam, admiram e levam à boca não mais de maneira involuntária. Buscam também pelas mãos das educadoras.

Paralelamente com o tempo de engatinhar, começam a desenvolver o movimento de pinça, o que os levam a procurar por migalhas e pequenos bichinhos como formigas. Em seguida começam a brincar com jogos de encaixe, fazendo insistentes tentativas; utilizam o toque para reconhecer e descobrir tudo que estiver ao seu alcance. São promovidos para a próxima fase quando começam a andar.

As avaliações são feitas do grupo no geral, porém contém observações individuais, são encaminhadas ao Departamento de Educação que, ao detectar algum problema, encaminha um relatório ao NAPE e à direção da escola, a qual orienta a professora e essa a sua ADI.

A etapa seguinte recebe o nome de Berçário 2, popularmente conhecida como B2,fase em que a habilidade motora fina é considerada de extrema importância para o desenvolvimento. São utilizados muito os jogos de encaixe, Lego, dominó gigante, massa de modelar. Como na escola do sistema privado, nessa fase, as refeições são feitassem ajuda, demonstrando eficiência em suas habilidades motoras manuais.

A próxima fase é chamada de Maternal 1, em que as crianças começam a cuidar do corpo sozinhos, buscando incessantemente por independência. Suas atividades manuais envolvem desenhos com interferências e já são capazes de segurá-los corretamente, são aplicadas atividades com papel crepom que os pequenos rasgam e enrolam bolinhas, porém essa sala visa a uma importância maior para estímulos de coordenação motora ampla.

\section{CONCLUSÃO}

Compreendemos que nas duas escolas há uma grande preocupação com a área de coordenação motora fina que são aplicadas de maneiras diferentes, mas com os mesmos propósitos, visto que entendemos que o educador deve tornar-se um facilitador mediador que estimula, no entanto respeita limites, devendo estabelecer com a criança um laço afetivo que lhe assegure ganhar a confiança do educando, um indivíduo ainda tão pequeno em fase de desenvolvimento, unindo aspectos emocionais e cognitivos ao movimento e a percepção de mundo da criança por meio da exploração e de conquistas através de estímulos e da reeducação psicomotora.

Contudo, concluímos que a estimulação precoce da coordenação motora fina pode contribuir para o desenvolvimento educacional infantil motivando a capacidade sensitiva através das sensações e relações com o corpo e com o exterior (o outro e os objetos), cultivando a capacidade perceptiva, a organização de movimentos; levando a descoberta de poderes de ação criativa e emocional, o que amplia e valoriza a autoestima transmitindo segurança e o fundamental para os profissionais da educação nesse processo é a busca do diálogo com as situações de ensino, com os outros e consigo mesmos num processo consciente de interpretação da realidade e de compreensão de que o crescimento/desenvolvimento profissional é fruto da partilha de saberes, de experiências, enfim, do trabalho reflexivo, construído de forma crítica, sistemática e coletiva. 


\section{REFERÊNCIAS}

[1] ABRAMOWICZ, A; WASKOP, G. Creches: atividades para crianças de zero a seis anos.São Paulo: Moderna, 1995.

[2] ARANHA, M. L. de História da educação 2. ed, São Paulo: Moderna, 1996.

[3] BAKHTIN, M. Por uma filosofia do ato. Trad. Carlos Alberto Faraco e Cristovão Tezza.(Mimeo.) 1993.

[4] BARBOSA, M. C. S. e HORN, M. G. S. Projetos pedagógicos na educação infantil.Porto Alegre: Artmed, 2008.

[5] BAUER, M. W. e GASKELL, G. Pesquisa qualitativa com texto: imagem e som: ummanual prático. 2ª Edição, Petrópolis - RJ: Vozes, 2003.

[6] BRASIL. Constituição da República Federativa do Brasil. Brasília, DF: SenadoFederal: Centro Gráfico, 1988. Disponível em:http://www.planalto.gov.br/ccivil_03/constituicao/constituicaocompilado.htm. Acesso em:10 mar. 2014.

[7] BRASIL. Senado Federal. Lei de Diretrizes e Bases da Educação Nacional: n 9394/96.Brasília: 1996.

[8] BRASIL, Ministério da Educação e do Desporto. Secretaria de Educação Fundamental. Referencial curricular nacional para a educação infantil. Volumes I, II e III. Brasília, 1998a.

[9] BRASIL, Ministério da Educação e do Desporto. Secretaria de Educação Fundamental. Subsídios para regulamentação e credenciamento das instituições infantis. Vol I.Brasília: Secretaria de Educação Fundamental, 1998b.

[10] BRASIL. Congresso Nacional. Plano nacional de educação. Brasília, DF, 2001.BRASIL, Ministério da Educação e do Desporto. Secretaria de Educação Fundamental. Parâmetros nacionais de qualidade para a educação infantil., Brasília, DF, 2005.

[11] BRASIL. Ministério da Educação. Secretaria de Educação Básica. Diretrizes curriculares nacionais para a educação infantil. Secretaria de Educação Básica. -Brasília : MEC, SEB, 2009.

[12] CATALDI, M. C. C. Modificações sociais e a participação da mulher no mercado de trabalho. In GAYOTTO, M. L. C. et al. Creches: desafios e contradições da criação da criança pequena. São Paulo: Leone, 1992.

[13] DEMO, P. Participação é conquista: noções de política social participativa. Fortaleza: Imprensa Universitária da Universidade Federal do Ceará, 1986.

[14] FONSECA, V. Desenvolvimento Psicomotor e aprendizagem. Porto Alegre: Artmed,2008.

[15] GADOTTI, M. Concepção dialética da educação: um estudo introdutório. São Paulo: Cortez, 2001.

[16] HADDAD, L. A creche em busca de identidade: perspectivas e conflitos na construção de um projeto educativo. 3ª edição. São Paulo: Edições Loyola, 2002.

[17] JUNIOR, M. K. Instituições pré-escolares assistencialistas no Brasil (1899-1922). Cadernos de Pesquisa, São Paulo, n.78, p.17-26, agosto. 1991. KRAMER, S. As crianças de 0 a 6 anos nas políticas educacionais no Brasil:educação infantil e/é fundamental. In: Educação e Sociedade, v. 27, n. 96 - Especial,p.797-818, out, 2006.

[18] KRAMER, S. (Org.). Com a pré-escola nas mãos: uma alternativa curricular para aeducação infantil. 6ª edição. São Paulo: Ática, 1993.

[19] LE BOULCH, J. Filogênese da motricidade. Psicomotricidade: Estruturas Psicomotoras.Artes médicas. Editora Artmed. Lisboa: Ed. 70, 1982.

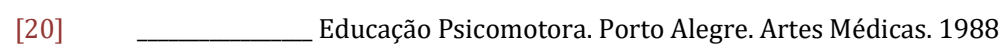

[21] O desenvolvimento psicomotor do nascimento até 06 anos.Porto Alegre. Artes Médicas. 1984

[22] LEVIN, E. A Infância em cena. Editora Vozes, 2002.

[23] Psicomotricidade: 0 corpo ajuda o aluno a aprender. Disponível em:http://revistaescola.abril.com.br/educacaofisica/pratica-pedagogica/esteban-levin-corpo-ajuda-aluno-aprender-423993.shtml. Acesso dia 10 de Jun. de 2013

[24] OLIVEIRA, G. C. Psicomotricidade: Educação e reeducação num enfoque psicopedagógico. Petrópolis/RJ: Editora Vozes, 1997.

[25] ___ Psicomotricidade: Educação e reeducação num enfoque psicopedagógico. 17 ed. Petrópolis/RJ: Editora Vozes, $201 \overline{2}$

[26] OLIVEIRA, Z.M.R. Creches: crianças, faz de conta e companhia. Petrópoles/RJ: Vozes,1992.

[27] PIAGET, J. A equilibração da estruturas cognitivas. Rio de Janeiro: Zahar, 1975.

[28] SABBAG, S. P. Creches surgimento, evolução e perspectivas. Presença Pedagógica. São Paulo: V.3 n.o 14 p. $13-21$ mar./abr. 1997.

[29] VEIGA, I. P. A. Educação básica e educação superior: projeto político pedagógico. Campinas: Papirus, 2004.WALLON, Henry. A evolução psicológica da criança. São Paulo:Ed. 70, 1968.

[30] Disponível em: http://www.portaleducacao.com.br/marketing/artigos/53756/fotografia-e-a-sua-importancia-para-asociedade\#ixzz3hs0wAZLA Acesso em: 21 jul. 2015.

[31] Disponível em: http://www.brasil.gov.br/educacao/2014/09/portal-brasil-esclarece-duvidas-sobre-matriculas-emcreches-publicasAcesso em: 10 ago. 2015 


\section{Capítulo 9}

\section{A importância da Educação Infantil na psicomotricidade}

\section{Anaiara Lourenço da Silva \\ Priscilla Patrício de Holanda}

Resumo: A importância da Educação Infantil na Psicomotricidade foi evoluindo em diversos aspectos que atualmente voltam a se agrupar, além de ser uma técnica que visa adquirir noções de esquema corporal, onde o professor deve buscar trabalhar com as crianças o seu desenvolvimento. E isso poderá acontecer com a realização de atividades simples como o engatinhar, rolar, jogar, brincar, entre outros. A música é muito importante na psicomotricidade, pois é através deles que as crianças desenvolvem a mente e o corpo para a que aprendizagem seja facilitadora e ocorra um significativo desenvolvimento motor.

Palavras-chave: Psicomotricidade, Educação Infantil, Música. 


\section{INTRODUÇÃO}

Nossa missão como educador é unir, formar pessoas e eliminar, distâncias entre elas e o mundo real. É dar-lhes qualificação intelectual, social e emocional de sobrevivência.

0 mundo se transforma a passos largos: a globalização, as novas tecnologias a corrida espacial, novas drogas, abertura sexual, novas doenças, o terrorismo sádico e político. Assim, o professor não pode se limitar aos muros da escola. É preciso que ele esteja sintonizado com o mundo à sua volta, para levar seu alunado propostas de trabalho que promovam seu crescimento e capacitação.

A importância da educação motora no desenvolvimento global dos estudantes das séries iniciais contribui com o aperfeiçoamento motor, ao nível dos domínios socioafetivo e cognitivo, o que toma as atividades de música e de jogos direcionados diretamente indispensáveis nesta faixa etária.

O papel dos professores em educação é de tamanha responsabilidade que é pensado e rediscutido, portanto o professor deve ser flexível às mudanças e aliar-se a elas para assim poder buscar a educação de seu alunado.

As atividades na educação infantil devem ser desenvolvidas como meio para estimular as crianças na primeira infância, proporcionando um atendimento integral, com qualidade ao indivíduo. Assim, ao realizar movimentos contínuos e planejados respeitar-se-á os limites do próprio corpo das crianças.

Neste contexto apresentamos a música, o jogo como uma diferente forma de se educar, na presença ou não de dificuldades de aprendizagem. A música e o jogo têm importante papel na educação infantil, para o estímulo da psicomotricidade pois é através deles que as crianças desenvolvem a mente e o corpo, para a que aprendizagem seja facilitadora e ocorra um significativo desenvolvimento motor (TEIXEIRA, 2007).

A música é uma manifestação corporal. Ao nascer, a criança entra em contato com o universo sonoro que a cerca, através de sons produzidos pelos seres vivos e pelos objetos, de modo que a relação estabelecida com a música é imediata. Vale ressaltar que a música tem o objetivo de fazer com que a criança conheça as diversas experiências e possibilidades culturais. Por isso é mister repensar os caminhos que levam ao desenvolvimento infantil por meio da música.

0 estudo da psicomotricidade na educação infantil busca compreender as distinções entre o crescimento natural e o desenvolvimento motor. Por isso a efetivação acontece basicamente da inter-relação entre diversos fatores que são: a hereditariedade, as condições da gravidez e do parto, os problemas de saúde, alimentação e ambiente.

Diante disso, é premente que o professor estimule o engatinhar, rolar, o balançar, entre outras gestualidades e expressões corporais, construindo possibilidades de avanço rumo às superações de dificuldades e lacunas decorrentes do uso dos métodos tradicionais.

\section{DESENVOLVIMENTO}

\subsection{A IMPORTÂNCIA DA EDUCAÇÃO INFANTIL NA PSICOMOTRICIDADE}

Em uma visão ampla, observa-se através das aulas na Educação Infantil que o homem, acompanha o processo da globalização, deixando de ser percebido como um ser essencialmente biológico e se tornando adulto mais rápido, sua fase de criança se completa mais cedo, muitas vezes pulando momentos essenciais, intervindo no seu processo social, histórico e cultural.

No século XVII, René Descartes ainda propunha esta dicotomia entre o corpo e alma, mas já fazia colocações de que o corpo é tão unido à pessoa que ambos chegam a "misturar-se". No século XIX constatou-se que existem disfunções graves evidenciadas no corpo sem que o cérebro tenha lesão. Segundo Levin, a psicomotricidade surge pela primeira vez, no ano de 1870, com as necessidades médicas de encontrar uma explicação dos fenômenos clínicos.

Wallon, em 1925, começou a relacionar a motricidade com a emoção, explicando que chamou de "diálogo tônico-emocional". E com isso, temos o fim do dualismo cartesiano que separa o corpo do desenvolvimento emocional e intelectual do indivíduo (TEIXEIRA, 2007).

Em 1948, Ajuriaguerra redefiniu a debilidade motora como sendo uma delimitação capaz de esclarecer os transtornos psicomotores no seu Manual de Psiquiatria Infantil, sendo um dos autores que na atualidade é citado nos estudos relacionados ao desenvolvimento infantil. 
Além dele, outros pesquisadores que se destacam na área são Jean Lê Boulch; André Lapierre; Bernard Auconturier; Aleksander Luria; Jean Bérges; Jean-Claude Coste e Vitor Fonseca, consagrando-se nesse universo do saber.

A psicomotricidade por ser um campo de estudos que gera muitas discussões, devido a sua complexidade, está associada a diversos fatores ligados ao eixo corporal. Segundo Fonseca (1995), a psicomotricidade apresenta sete fatores, dentre os quais são: a tonicidade; o equilíbrio global; a estruturação espaçotemporal; a noção corporal; apraxia fina e a lateralidade.

Parafraseando Goretti (ano) "são várias as classificações e as terminologias utilizadas para dominar as funções psicomotoras". De qualquer forma, os conceitos são basicamente os mesmos, o que muda é a forma de classificação e o agrupamento destes conceitos. Assim, as terminologias mais utilizadas no Brasil e seus respectivos conceitos são os seguintes:

Esquema corporal - é o saber pré-consciente que diz respeito ao seu próprio corpo e de suas partes. É aceitar que o sujeito se relacione com espaços, objetos e pessoas que o circundam, dessa forma, são as informações proprioceptivas ou cinestésicas é que constroem este saber acerca do corpo e à medida que o corpo cresce, acontecem ajustes e modificações no esquema corporal. Exemplo: a criança sabe que a cabeça está em cima do pescoço e sabe que ambos fazem parte de um conjunto que é o corpo.

Imagem corporal - é a representação mental inconsciente que fazemos do nosso próprio corpo, formada a partir do momento em que este corpo começa a ser desejado e, consequentemente a desejar, a ser marcado por uma história singular e pelas inscrições materna e paterna. Um exemplo de como se dá sua construção é o estágio do espelho que começa aos 6-8 meses de idade, quando a criança já se reconhece no espelho, sabendo que o que vê é sua imagem refletida. A imagem, portanto, vem antes do esquema, portanto, sem imagem, não há esquema corporal.

Tônus - é a tensão fisiológica dos músculos capaz de garantir o equilíbrio estático e dinâmico, coordenação e postura em alguma posição pelo corpo, esteja ele parado ou em movimento. Exemplo: a maioria das pessoas portadoras de Síndrome de Down possui uma hipotonia, ou seja, uma tonicidade ou tensão menor do que a normal, o que faz com que haja um aumento da mobilidade e da flexibilidade e uma diminuição do equilíbrio, da coordenação e da postura.

Motricidade ampla ou Coordenação global - é a ação simultânea de diferentes grupos musculares que exercem um movimento voluntário, amplo e relativamente complexo. Exemplo: para caminhar utilizamos a coordenação ampla, fazendo com que o deslocamento ocorra através das partes superiores e inferiores, alternando as coordenadas.

Motricidade fina - é a capacidade de realizar movimentos coordenados, favorecendo os pequenos grupos musculares das extremidades. Exemplo: costurar escrever, digitar.

Organização espaço-temporal - é a capacidade de orientar-se completamente no espaço e no tempo. Para isso, é preciso ter a noção de perto, antes, depois. Alguns autores estudam a organização espacial e a organização temporal separadamente. Exemplo: a brincadeira "Batatinha frita 1, 2, 3".

Ritmo - é a ordenação permanente e periódica de um ato motor. Para se ter ritmo é necessário ter organização espacial. Exemplo: pular corda.

Equilíbrio - o equilíbrio está presente diretamente nas tarefas seja de uma criança ou adulto, jogando ou pedalando uma bicicleta, o mesmo reúne um conjunto de competências estáticas é sem movimento, enquanto as dinâmicas usam movimento, envolvendo o controle postural, que demanda uma boa tonicidade, levando-se em conta o desenvolvimento das aquisições de locomoção. Enquanto equilíbrio é determinado pela posição, ou seja, capaz de apresentar capacidade de cumprir certa postura sobre uma base. Já o equilíbrio dinâmico é conseguindo pelo o corpo que está em movimento, capaz de determinar alterações sucessivas, ou seja, com base em sustentação, em uma simples caminhada e requer um equilíbrio para sua realização.

Tonicidade - tem um papel fundamental no desenvolvimento motor da criança, mas infelizmente tornase imperceptível para alguns profissionais, a tonicidade garante as atitudes em grupo e individual. A postura, a mímica, as emoções, de onde surgem toda a atividade motora humana.

Praxia global - é a colocação em atuação simultânea de grupos musculares alterados, fazendo com que aconteça uma execução dos mais amplos e voluntários movimentos, capazes de envolver o trabalho dos membros inferiores, superiores e do tronco. 
Praxia fina - apresenta uma função com suas potencialidades de movimento das mãos, segmento que ocupa dois quadros do córtex, que é caracterizado como uma unidade motora mais complexa do mundo animal. A praxia trabalha os pequenos músculos de forma ordenada, fazendo com que as crianças que tem um transtorno na coordenação dinâmica tenha vários problemas motores, ou seja, devido este problema são apresentadas inúmeras dificuldades no desenho, no recortar, no escrever, e em todos os movimentos que solicitem a coordenação olho/mão.

Noção corporal - apresenta a formação do eu, da personalidade, levando a compreensão do desenvolvimento e da noção ou até mesmo no esquema corporal, que acontece com as crianças quando ela toma consciência do seu corpo e das possibilidades de expressão pelo intermédio.

A psicomotricidade procura outras linhas de análise que em estudo capaz de representar a psicologia e a linguística, abordem seu potencial de alfabetização e também as relações inseparáveis.

Estruturação espaço-temporal - a estruturação espaço-temporal percorre como preparação funcional da lateralidade e da noção corporal.

A motricidade é um fator que emerge a relação que fica localizada numa posição relativa ocupando o corpo, ou seja, a múltipla relação que estão integradas na tonicidade, no equilíbrio, na lateralidade e no esquema corporal. Essa estrutura espacial está ligada na tomada de decisões da criança, e de seu próprio corpo em um determinado meio ambiente, levando à consciência e à orientação do espaço que pode ter uma relação com as pessoas e coisas.

Lateralidade - é a capacidade de vivenciar os movimentos adaptar os dois lados do corpo, ora lado esquerdo, ora direito. Por exemplo: a criança destra, mesmo tendo sua mão direita ocupada, é capaz de abrir uma porta com a mão esquerda. É diferente da dominância lateral que é a maior habilidade desenvolvida num dos lados do corpo devido à dominância cerebral, ou seja, pessoas com dominância cerebral tem maior probabilidade de desenvolverem suas habilidades do lado direito do corpo e, por isso, são consideradas destros. Com os canhotos, o inverso já que sua dominância cerebral é do lado direito. Segundo Fonseca (1989):

[...] A lateralidade estabelece o que é essencial no processo das relações da motricidade e da organização psíquica intersetorial. Representa a informação na íntegra, ou seja, simbolizam os dois lados do corpo, tanto o direito como o esquerdo, pressupondo a linha média do corpo. Essas relações se dão através da orientação da face aos objetos, aos símbolos e imagem, levando a lateralização que interfere na aprendizagem escolar de maneira eficaz e decisiva. (FONSECA, 1989, p. 69),

A lateralidade permite o estabelecimento lateral da mão, do ouvido e do pé do mesmo lado do corpo. É importante que a lateralidade corporal possa se restringir a um espaço interno, utilizando um lado do corpo com maior desembaraço. Sendo assim, a lateralidade acontece devido a noção de direita e esquerda, capaz de envolver o esquema corporal.

É importante ressaltar que a noção de lateralidade não está bem definida. 0 problema é a dificuldade que acontece quanto à discriminação e na diferenciação entre os lados do corpo, e a desigualdade ao seguir a direção gráfica.

Pesquisas sobre o tema mostram que a lateralidade manual surge nos primeiros anos de vida, mas só é concluída fisicamente por volta dos $4-5$ anos.

Para melhor desempenho da lateralidade e das noções de espaço é importante que durante a infância os pais possam fazer um trabalho de diferenciação entre direita e esquerda, e noções de intervalo dos elementos que posicionam tanto do lado direito como do lado esquerdo, facilitando na educação motora da criança e consequentemente em predominância lateral.

Os movimentos bilatérios, ou seja, que usam os lados de modo simultâneo e paralelo, como, por exemplo, segurar uma caixa de papelão com as duas mãos, e os movimentos unilaterais que envolvem o uso de apenas de um membro por vez, como, por exemplo, a saldar uma pessoa apertando sua mão. 
Esquerda é o lado oposto à direita e, por exclusão, a direita é o lado oposta à esquerda, é necessária esta definição, pois a lateralidade é usada em rotinas diárias. Deve se esclarecer também que esquerdo é um sentido da direita para a esquerda, e direito é um sentido do lado esquerdo para o direito. Usamos a lateralidade em uma simples brincadeira infantil, em um movimento de trânsito, enfim, em ponto de determinação espacial, têm sua importância capital para a configuração individual de localização e, portanto, tem diversas acepções consoantes à área de conhecimento ao qual se aplica.

Durante o crescimento da criança é natural que se defina uma dominância lateral na mesma, dificilmente a criança apresentará habilidades iguais com ambos os membros, essa preferência de membro acarreta uma maior força e agilidade do lado dominante. A Lateralidade retribui a dados neurológicos, mas também é influenciada por certos hábitos sociais ou até mesmo familiares.

Escolheu-se por avaliar somente os fatores referentes à lateralidade, pois através das vivências nas escolas percebe-se a carência neste aspecto que se faz indispensável para um bom desenvolvimento do indivíduo.

A psicomotricidade contribui significativamente para a formação da criança, tanto na estruturação corporal quanto no seu comportamento social. Assim, o seu desenvolvimento, proporcionará uma melhor orientação espacial, e um melhor convívio social. Para essa melhor assimilação de conhecimentos é necessário um bom trabalho psicomotor nos primeiros anos da criança, pois a Educação Infantil em relação à Psicomotricidade se baseia nas necessidades da criança, Le Boulch (1987) afirma que:

[...] A educação psicomotora é capaz de condicionar todas as aprendizagens da pré-escolar e escolar, ou seja, não pode ser conduzido um bom termo se a criança não dominar o tempo, não tiver habilidade suficiente. Por isso a educação deve constituir privilégio desde a tenra infância levado com perseverança, admite prevenir certas inadaptações sempre difíceis de melhorar quando já estruturadas. (LE BOULCH, 1987 p. 11).

Essa justificativa traz a importância da educação infantil, pré-escola até a antiga quarta série do ensino fundamental (hoje 5o ano do ensino fundamental) em que se manifesta as diversas perturbações de percepções. A reeducação psicomotora, em muitos casos, permite obter resultados espetaculares, já que se encontra em fase inicial. Logo, seu ideal é mais bem sucedido, uma vez que o trabalho psicomotor nas séries iniciais auxilia na estruturação do esquema corporal.

0 período pré-escolar é a fase em que a criança passa a ter aquisição de habilidades motoras, além de fazer com que os movimentos sejam considerados fundamentais. Portanto, para que a criança possa ter um crescimento corporal e seus movimentos mais completos, possibilitando o domínio do corpo e garantindo o movimento, ao vivenciar a realização das atividades motoras.

A vivência de diversas manifestações pelo ser humano, o permite constituir seu mundo, sua personalidade, seu caráter. Dessas experiências a criança terá uma maior dimensão das noções das diferenças, de modo que as experiências lhe proporcionem um melhor desempenho de aprendizagem corporal e motora, consequentemente autonomia e segurança na vida social.

A motricidade é de uma extrema coerência no que somos, pensamos, sentimos e acreditamos, é tudo aquilo que expressamos por meio da postura, dos gestos ou mesmo os movimentos mais amplos. A psicomotricidade por ser um campo que gera muitas discussões e por ser complexa está associada a diversos fatores ligados ao eixo corporal.

A Educação Infantil no Brasil surgiu na década de 1970, contemplando crianças de 0 a 6 anos, em que adquiriu um estatuto no campo político e de teorias educacionais. Buscando o desenvolvimento de políticas públicas que amparem as creches e pré-escolas, que façam diferentes movimentos sociais, ou seja, capazes de intermediarem grandes proposições às mudanças.

A infância surge com a modernidade da família burguesa, porque nessa época a criança era cuidada, valorizada, protegida, entre outros. Com isso tratamos a pré-escola, a creche, o berçário, o maternal sendo partes fundamentais da instituição escolar, ou seja, é um ambiente propício para a interação, a troca de experiências, e o convívio, para que sejam desenvolvidas metodologias e práticas pedagógicas.

A vida escolar das crianças inicia-se quando os pais colocam seus filhos na creche ou no berçário, proporcionando que tenham uma formação e uma aprendizagem para a vida em sociedade. Nesse sentido, é fundamental que essa etapa escolar valorize o corpo e os movimentos, para que sejam desenvolvidas as habilidades como: habilidades motoras, habilidades comportamentais e expressivas, levando ao desenvolvimento da criança. 
Hoje a infância é diferente, em decorrência das mudanças que aconteceram na sociedade em busca de suprir as necessidades de segurança e do avanço tecnológico, o que reduziu bastante o espaço e a liberdade para as crianças brincarem.

A Educação Infantil deve ser uma instituição onde as crianças possam frequentar e enriquecer todo o desenvolvimento e inserção social, cumprindo um papel para socializar, proporcionar seu desenvolvimento de construção da identidade entre as crianças. Por meio de um aprendizado diversificado que promova a interação.

A psicomotricidade na educação infantil é usada para que as crianças possam brincar jogar, dançar, etc., para que seja estimulada sua individualidade, seu grupo social e sua cultura corporal, levando ao desenvolvimento significativo.

Para um crescimento saudável dessas crianças, em que estas sejam capazes de desenvolver seu emocional, cognitivo e até mesmo o potencial biológico, é que as práticas educacionais da educação infantil são pautadas pelas seguintes Diretrizes Curriculares Nacionais:

- A matrícula é obrigatória para aquelas crianças que completam 4 ou 5 anos até o dia 31 de março no ano de sua matrícula;

- Quando a criança completar 6 anos após o dia 31 de março devem ser matriculados na educação infantil;

- Não deve esquecer que a frequência na educação infantil não é um pré-requisito para que a criança seja matriculada no ensino fundamental;

- É importante que as vagas oferecidas em creche e pré-escolas sejam próximas às residências das crianças.

Quando pensamos a educação e todo o completo processo escolar, isso significa que deve proporcionar situações, brincadeiras e aprendizagens que as oriente de forma integralizada. Tanto a promoção de suas capacidades de relação interpessoais quanto as capacidades de apropriação afetiva, emocional, entre outros.

O professor sempre deve ter em mente que trabalhar com a psicomotricidade na educação infantil é levar ao conhecimento, habilidades e instrumentos que são capazes de chegar a uma integração da educação, para que a criança possa se socializar em diferentes áreas. Nesse aspecto, ele tem o papel de fazer com que a criança compreenda e ajude ao outro a desenvolver-se em sua humanidade. De acordo com o Referencial Curricular Nacional para Educação Infantil (1998, p. 24):

0 professor que cuida de sua criança, ela vai aprender a ajudar e valorizar seu desenvolvimento capacidades que pode acontecer apenas no ato em relação a si próprio e com os outros que tem uma expressiva dimensão e implica em um procedimento variado.

Para que a criança se desenvolva bem é necessário que o professor confie e acredite que elas são capazes de realizar qualquer trabalho. 0 professor sempre deve transmitir informações para as crianças de forma que possibilite estabelecer vínculos com elas. Assim sendo, deve sempre respeitar os hábitos, os ritmos e as preferências individuais. Quando a criança é ouvida e compreendida é fortalecida nela sua autoconfiança.

As crianças sempre chamam o professor de "tia" e "tio" pois elas o (a) identificam como sendo um membro da família. Uma atividade que significa para o professor que seu aluno desenvolva é o faz-de-conta em que a criança possa imitar ações que pode representar diferentes personagens, pessoas ou animais, etc. Isso faz com que aconteça uma interação com uma ou mais crianças, no qual pode ser compartilhado um mesmo objeto, como exemplo empurrar o berço como sendo um meio de transporte, cuidar do cachorrinho, entre outros.

$\mathrm{Na}$ educação infantil o professor deve recomendar trabalhar e orientar as crianças a usarem utensílios, objetos de forma segura, mas nunca o professor deve esquecer-se de orientar as crianças sobre o cuidado dos objetos pontiagudos e cortantes e quando for preciso sempre acompanhado por um adulto.

Os distúrbios da aprendizagem são um indicador do desenvolvimento. 0 papel do professor, a escola e família na busca pela superação deste problema que é essencial para transpor o fracasso escolar. 
Com o objetivo de facilitar a aprendizagem da leitura e da escrita tem sido realizados estudos pelo MEC acerca das habilidades envolvidas nesses dois processos. A finalidade desses estudos é a de definir operacionalmente cada habilidades para que possam ser estimulados no período pré-escolar e consequentemente facilitar a alfabetização.

No entanto, o desconhecimento acaba ocasionando o reconhecimento e o diagnóstico dessas crianças tardiamente, o que tem como frequência o agravamento de problemática. Geralmente, ela é encaminhada para a reeducação depois de ter reprovado um ou dois anos seguidos e ter automatizado os erros de leitura. Desta forma, o processo educativo que poderia ter sido simples e breve, torna-se complexo demorado e permeado de ansiedade, tanto por parte dos pais, os quais querem ver o problema logo resolvido, como por parte das crianças que gostariam de superar rapidamente os obstáculos, e assim, acompanharem a classe, deixando de cair nas punições e zombarias de professores e colegas.

As questões educacionais têm preocupado os profissionais que estão ligados ao ensino, refere-se que tem sido registrada nas escolas municipais e estaduais, o grande número de crianças que tem recorrido e tratamento psicopedagógico com dificuldades de aprendizagem. (PAMPLONA, 1989, p.29).

Sendo assim faz-se necessário o reconhecimento e a identificação das dificuldades em aprender a ler e a escrever, pois é esta na maioria das vezes, a diferença entre o fracasso e o sucesso escolar. Infelizmente, não existe dados estatísticos acerca dos índices de reprovação e evasão nas escolas particulares, mas pode-se afirmar, com toda a certeza que é grande o número de crianças que apresentam problemas em aprender a ler e a escrever.

A única maneira de se reverter esta situação e buscar as reais dificuldades encontradas na aprendizagem, levando a criança a aprender e a gostar de fazer. Quando isto não ocorre é porque alguma coisa não está indo bem. Neste momento, é necessário que tanto os professores como os demais profissionais responsáveis pelo processo de aprendizagem, se questionem acerca dos fatores que podem estar contribuindo para que o aluno não consiga aprender.

No processo educativo, o professor também possui um papel de destaque. Na verdade, dificilmente um psicopedagogo pode ter sucesso em seu trabalho não houver a colaboração do educador. Inicia-se a criança na vida escolar, precocemente e muito de seu desenvolvimento natural de aprendizagem (as etapas de desenvolvimento) não é respeitado adequadamente à capacidade de cada idade.

As crianças são levadas a vida escolar prematuramente para dar espaço de tempo a mãe que assume cada vez mais espaço no mercado de trabalho, mas que se torna ausente da vida estudantil do filho e muita das vezes da afetiva, complicando ainda mais a problemática do desenvolvimento da criança que em seu processo natural necessita de apoio materno, amor, proteção e carinho para passar com sucesso.

A música na Educação Infantil tem um papel importante, pois leva a colaborar no desenvolvimento da mente, do corpo, para que a aprendizagem seja facilitada e que tenha um desenvolvimento motor. A criança com a música aprende a caminhar, embalar ao ritmo que é tocado. Segundo Gardner (2002):

Para Gardner a inteligência humana é demonstrada na vida social é a inteligência musical, isso acontece a partir do momento que saímos do útero da mãe e dos demais familiares, a criança descobre um mundo de sons do ambiente em que vive isso acontece através da voz da mãe e dos demais familiares. Levando a uma função de educação que usa a música como estímulo ao desenvolvimento de várias habilidades e competências humanas. (GARDNER, 2002, p. 94).

Por isso o educador nunca deve renunciar à música, as rodas cantadas, jogos musicais, para que seja explorada a produção de ritmos. A música deve estar presente nas ações pedagógicas diárias e deve ser utilizada na escola para que seja alcançado um objetivo lúdico e expressivo para representar um meio que estabelece os vínculos interpessoais e fomentar a socialização.

Com a música a criança compartilha suas energias, suas expressões, suas espontaneidades, entre outros. Quando a criança canta ou produz o som com instrumentos, ela é capaz de se integrar às habilidades psicomotoras individuais, sendo promovida a sociabilidade.

A professora pode usar vários instrumentos musicais como cantar, bater palmas com ritmo entre outros, para que o desenvolvimento possa ser uma prática simples e de grande valor, possibilitando a descoberta do ritmo e do exercício de coordenação motora. 
É importante que as atividades musicais sejam bem vindas em sala de aula. Mas não pode ficar preso só em cantigas de roda, devemos ir além para não afastar as crianças da realidade porque hoje elas escutam vários tipos de músicas.

É importante que a música seja uma linguagem capaz de formar os conhecimentos que estão presentes no cotidiano da criança, como por exemplo, a TV, o rádio, etc., além das brincadeiras que pode fazer com que o professor o os familiares criem situações de convívio social, linguagem musical que estrutura as suas próprias características.

Anteriormente ao fazer musical, segundo Bee (1984), devem-se estabelecer os objetivos que se quer alcançar, pois sem uma plataforma de partida sólida e que venha de encontro aos resultados a serem alcançados, dificilmente as crianças com distúrbios de aprendizagem conseguiram atingir índices de aprendizagem.

A linguagem musical leva a criança a ter alegria e um grande prazer, pois as atividades têm um caráter lúdico, de jogo, de brinquedo. A música por si só é um instrumento valioso para a aprendizagem no geral. Ela é grande recurso que podemos lançar não apenas nos horários estipulados, mas durante várias vezes ao dia, como um remédio eficaz que fará com que as crianças se sintam motivadas a participar das atividades diárias que serão propostas.

O ambiente de trabalho, nas salas ou fora delas, deve ter um clima de liberdade, alegria e desconcentração, inteiramente propício ao desenvolvimento das atividades espontâneas e criativas. 0 professor deverá estar pronto para receber respostas diferentes e respeitar as individualidades.

As experiências sonoras (relativas ou pertencentes aos sentidos ou sensação) deverão ser apresentadas com maior frequência para que ocorra o desenvolvimento, com aprendizado. Tais oportunidades devem levar a criança a observar, imaginar explorar, improvisar, criar, concentrar-se e, em cada uma, ela iniciará suas próprias diferenciações.

Antes de iniciar o seu trabalho, o professor deve fazer avaliações que o ajudarão no planejamento das atividades a serem efetivadas: do número de alunos, de quais instrumentos dispõe e do local que irá utilizar.

E importante o preparo das aulas, mesmo que o professor seja um experto em música. Neste preparo devem ser planejadas quais as necessidades dos alunos e quais os objetivos que se deseja atingir: organizando os conteúdos que deverão ser paulatinamente desenvolvidos, pois dependerão das respostas dos alunos; propondo atividades variadas e criativas, para que haja um interesse adequado a esta linguagem de expressão.

0 professor deve estar atento para que a criança consiga filtrar todas as mensagens, principalmente, quanto à linguagem musical. Para tanto, deve-se perceber a analisar como a linguagem musical é utilizada e, na maioria das vezes manipulada. As crianças devem ser conscientizadas desde a primeira série.

Na educação musical, os conteúdos são desenvolvidos paralelamente à formação e de regras sociais fundamentais para a convivência na sociedade.

\section{CONCLUSÃO}

Vale ressaltar a importância da psicomotricidade na educação infantil, pois ela veio para preconizar a necessidade dos profissionais para atender a educação infantil, levando ao desenvolvimento correto dando as crianças e jovens a desenvolver atividades de música e jogos, para resolver qualquer problema que está relacionado ao meio.

0 professor tem que respeitar os limites de seus alunos trabalhando de preferência com o lúdico em sua infância, as autoridades responsáveis pela educação devem ficar atentas às crianças logo no pré-escolar ou creches, já que seu desenvolvimento é constante principalmente nos dez primeiros anos, abrindo ai uma oportunidade de trabalho através da inserção de um professor.

0 professor, hoje mais do que nunca, é uma tarefa que exige qualificação, experiência e inteligência, pois o educador cada dia mais assume o papel que antes era exclusivo da família. É o novo modelo de sociedade que surge com uma mulher trabalhadora, ativa e independente, cada vez mais distante dos filhos e de suas obrigações de mãe. Surge assim uma nova problemática para os educadores: a chegada a escola de crianças cada vez mais carentes, tristes e com baixa autoestima. Como trabalhar eficientemente uma 
quantidade cada vez maior de crianças problemas em sala-de-aula? Que linguagem aplicar? Quem são estes alunos e como diagnosticar o seu problema?

Existem inúmeras técnicas metodológicas, conteúdos e linguagens que podem ser usadas na solução universal comum a todos os problemas de cada aluno. Cada aluno exige um tipo diferente de solução do seu problema. É preciso estar aberto as mudanças para se puder superar a problemática nãoaprendizagem, assim como buscar sempre que possíveis novos caminhos que possam nos dar condições de vencer o pior inimigo da educação: o fracasso escolar.

Mas não basta falar de estética e de beleza às crianças, se não as vivenciamos. Daí o grande papel do educador, que sente, percebe e vive, e que necessariamente deve desenvolver qualidades auditivas e ter gosto pela música e contato com ela.

Além da competência técnica, o professor deve ser criativo. A necessidade de citar é comum a todas as crianças, que, ao interagirem com o mundo, constroem seu conhecimento. 0 educador não deve perder a oportunidade de aproveitar essa disposição.

Nosso dever é sonhar a humanidade de amanhã, preparar o caminho do progresso futuro e legar aos nossos descendentes instintos mais nobres, aspirações mais elevadas. A música deve continuar a viver nas civilizações futuras, não somente como forma de divertimento, mas como um grande aliado a serviço da educação e da terapia musical.

Concluímos que a música pode facilitar a aprendizagem da leitura e da escrita tanto em crianças disléxicas. 0 que propomos e simplesmente um meio mais humano de ensinar a estas crianças hoje tão marginalizadas em sala de aula. É fazer com que a criança aprenda brincando e busque o conhecimento por vontade própria. Não é a solução, mas um avanço rumo à aprendizagem, pois o pouco se conquista é muito para as crianças.

A música é sim capaz de aperfeiçoar resultados que os métodos tradicionais em outro momento não conseguiram atingir, pois ela nada mais é que a "combinação harmoniosa da física e a matemática somada ao puro sentimento humano".

\section{REFERÊNCIAS}

[1] ABROMOVICH, F. Quem educa quem? São Paulo: Summus. 1999, p. 67.

[2] ALMEIDA, Ana Cristina. C. Sawaya. Arte no desbloqueio da escrita. Goiânia: Gráfica e Ed. Vieira, 2001.

[3] BACKTIN, M. Marxismo e filosofia da linguagem. São Paulo: Hucitec, 1992.

[4] BARBOSA, Maria Carmem Silveira. Por amor e por força: rotinas na educação infantil, Porto Alegre: Artmed, 2006.

[5] BRASIL Ministério da Educação e do Desporto. Secretária de Educação Infantil. Referencial Curricular Nacional para a Educação Infantil, volume 01. Brasília: MEC/SEF, 1998.

[6] BRASIL Ministério da Educação. Secretária de Educação Básica. Diretrizes Curriculares nacionais para a Educação Infantil. Brasília: MEC/SEF, 2010,

[7] DAMAZIO, Fernando. 0 olhar em construção: uma experiência de ensino e aprendizagem da arte na escola. São Paulo: Cortez Ed. 1991.

[8] FONSECA, Patrícia. Discurso da sala de aula e o processo de ensino/aprendizagem. Ed. Luzes. 2000.

[9] FONSECA, Vítor da. Desenvolvimento Humano. Coleção Pedagógica. Rio de Janeiro, Editorial Notícias, 1989.

[10] GARDNER, Howard. As Artes e o desenvolvimento humano. (Trad. Maria Adriana Veríssimo Veronese). Porto Alegre: Arte Médicas, 1997.

[11] JEANDOT, Nicole. Explorando o universo da música. São Paulo: Scipione, 1993.

[12] LE BOULCH, Jean. Educação psicomotora: a psicomotricidade na idade escolar. Porto Alegre: Artes Médicas, 1987.

[13] LE BOULCH, Jean. Educação psicomotora: psicocinética na idade escolar. Porto Alegre: Artes Médicas, 1987.

[14] MANOLO, Edigar de “Amalyses musicais”. IN: Com. Naissace de la musique-frace, 1970.

[15] MEUR, A. de. Psicomotricidade: educação e reeducação: níveis maternal e infantil. São Paulo: Manole, 1989. 
[16] OTONI, B.B.V., 2007. A Psicomotricidade na Educação Infantil. Disponível em: <http://www.psicomotricidade.com.br/artigos-psicomotricidade_educação.htm>

[17] PAMPLONA, Geraldo de Oliveira; fator preponderante na construção do ser. São Paulo: CLR Balieiro, 1997.

[18] SILVA, Daniel Vieira da. Ludicidade e psicomotricidade. Curitiba: IESDE Brasil S.A., 2008.

[19] SOUSA, Paul Bruner. O processo da educação. São Paulo: Cia Ed. Nacional, 2001.

[20] TEIXEIRA, Luzimar. Psicomotricidade na Educação Infantil: desenvolvendo capacidades. Especialização Atividade Física e adaptada à saúde, 2007. 


\section{Capítulo 10}

A importância da psicomotricidade no desenvolvimento cognitivo e corporal da criança: Uma visão reeducadora no contexto escolar

\section{Vanderlea dos Santos Silva}

Resumo: 0 presente artigo busca estudar e compreender a importância da psicomotricidade para o desenvolvimento infantil no âmbito escolar. Objetivando uma significativa base de conteúdos sobre esta temática através de uma análise bibliográfica. Foram apresentados os conceitos da psicomotricidade e a sua contribuição para o desenvolvimento infantil numa perspectiva pedagógica. Além disto, procurou-se compreender como funciona o processo de ensino baseado em uma educação que estimule o desenvolvimento psicomotor nas crianças em seus primeiros anos de vida no âmbito escolar, procurando refletir sobre este processo. Visto que é indispensável para os professores da educação infantil obtenham conhecimentos voltados para a psicomotricidade.

Palavras-chave: Aluno, Escola, Infância, Movimento, Mente. 


\title{
1. INTRODUÇÃO
}

0 estudo referente à psicomotricidade iniciou a partir da necessidade acerca da compreensão desta temática, tendo em vista a sua importância no contexto evolutivo humano. Além disso, tendo em vista que a mesma é considerada uma ciência que estuda a relação entre os movimentos de um indivíduo com o meio pelo qual ele está inserido, tornando-se assim, de suma importância ressaltar a sua contribuição para a comunidade escolar.

Para a construção da fundamentação teórica referente ao presente estudo, foi executada uma coleta de dados por intermédio de livros, revistas e internet. As informações apresentadas foram fundamentadas através da visão de vários autores sobre os conceitos da psicomotricidade e o desenvolvimento infantil visando a sua contribuição para a educação. Os estudos e analises foram realizados através da concepção de autores como, Fonseca (1988), Le Boulch (1987), Oliveira (2000) sendo eles fundamentais para o desenvolvimento deste trabalho.

Os objetivos do presente estudo são estudar e ampliar os conceitos da psicomotricidade e compreender a sua contribuição para o desenvolvimento infantil em uma perspectiva pedagógica. Outro aspecto abordado é demonstrar a importância dos profissionais da educação por possuírem conhecimentos nesta área para ampliação das suas práticas pedagógicas.

\section{METODOLOGIA}

Esta pesquisa buscou estudar a importância de compreender o que é a psicomotricidade e a sua contribuição para o desenvolvimento motor de uma criança. A análise do presente estudo sucedeu por meio da pesquisa qualitativa com caráter exploratório e descritivo. Com isso, o presente trabalho propõe uma considerável investigação da temática abordada.

A captura de dados do nosso estudo ocorreu através da pesquisa bibliográfica. Alem disso, foram consultados sites no intuito de ampliar o nosso conhecimento acerca do nosso trabalho. Visto a importância da temática para o processo de desenvolvimento do aluno.

\section{REFERENCIAL TEÓRICO}

\subsection{A PSICOMOTRICIDADE NO DESENVOLVIMENTO INFANTIL}

Embora os estudos voltados para psicomotricidade sejam atuais, os autores Fonseca (1995) e Araújo (1992) ressaltam que o termo "psicomotricidade" foi elaborado em 1907 pelo médico neurologista Ernest Dupré16 (1862-1921) em um discurso cientifico, onde o mesmo relacionou a motricidade com o cognitivo, assim sendo, as primeiras pesquisas desta área aconteceram numa perspectiva neurológica. Enfatizando a historicidade do termo psicomotricidade, Fonseca (1988) retrata que:

\begin{abstract}
A história da psicomotricidade, representada já um século de esforço de ação e de pensamento, a sua cientificidade na área da cibernética e da informática, vai-nos permitir certamente, ir mais longe da descrição das relações mútuas e recíprocas da convivência do corpo com o psíquico. Está intimidade filogenética e ontogenética representam o triunfo evolutivo da espécie humana; um longo passado de vários milhões de anos de conquistas psicomotoras (FONSECA, 1988, p. 99).
\end{abstract}

Partindo desse preceito, segundo Fonseca (1988), para o estudo referente á psicomotricidade é necessário analisar outras áreas do conhecimento, como por exemplo, o processo de evolução humana. Assim, é importante compreender o comportamento motor e o desenvolvimento humano. Corroborando com esta idéia, Coste (1978), enfatiza que a psicomotricidade é resultante do processo histórico do corpo e que existe uma relação entre a mente e a afetividade. Ou seja, ambas estão interligadas. Portanto, a mente possui influência sobre os movimentos físicos.

É importante ressaltar que, o indivíduo relaciona o mundo interno com o externo. Ou seja, ambos estão interligados e com isso, influência no desenvolvimento motor individual de cada pessoa. Á princípio, as análises voltadas para esta área apresentavam-se apenas teoricamente, principalmente referente ao

16 Ernest Dupré (1862-1921) foi um neurologista e Psiquiatra francês. Conhecido internacionalmente como o "pai da psicomotricidade". 
desenvolvimento motor da criança em relação aos estudos das habilidades motoras conforme a idade. Neste parâmetro, Wallon estuda a relação entre o movimento humano e a vida afetiva fazendo assim, uma ligação direta entre ambos, com o meio ambiente e os hábitos de cada indivíduo.

É importante mencionar que, alguns fatores externos poderão influenciar no desenvolvimento psicomotor de uma criança. "Quanto maior o número de fatores de risco atuantes, maior será a possibilidade do comprometimento do desenvolvimento. (Gallahue, 2005, p. 55). Neste sentido, algumas circunstâncias como, por exemplo, as crianças que nascem prematuras, podem desencadear um atraso em seu desenvolvimento. Além disso, é importante ressaltar que, quanto mais um indivíduo é exposto a fatores externos, mas poderá ter um agravamento prejudicial em seu desenvolvimento, tanto cognitivo quanto psicomotor.

Nesta perspectiva, a Associação Brasileira de psicomotricidade (ABP) afirma que a psicomotricidade é uma ciência que estuda a relação do mundo externo e interno do indivíduo. Esta interligação vai determinar o desenvolvimento cognitivo e psicomotor de uma pessoa que poderá desenvolver de forma positiva ou negativa. A habilidade de o indivíduo relacionar-se com o outro e enxergá-lo dentro de um contexto social contribuirá para o amadurecimento cognitivo, afetivo e orgânico.

\section{A PSICOMOTRICIDADE NA FASE ESCOLAR}

É na fase escolar que a criança constrói as suas primeiras relações extras familiares, e as mesmas poderão influenciar diretamente no seu desenvolvimento físico e cognitivo. É na primeira infância que, a criança consegue melhorar a sua autonomia diante do seu movimento corporal. Portanto é necessário que um indivíduo nos seus primeiros anos de vida possua acesso a uma educação que o estimule psicomotricamente para um desenvolvimento motor saudável. Neste sentido Le Boulch (1987) relata que:

A educação psicomotora deve ser considerada como uma educação de base na escola primária. Ela condiciona todos os aprendizados pré-escolares: leva a criança a tomar consciência de seu corpo, da lateralidade,a situar-se no espaço, a dominar seu tempo, a adquirir habilmente a coordenação de seus gestos e movimentos. A educação psicomotora deve ser praticada desde a mais tenra idade: conduzida com perseverança, permite prevenir inadaptações difíceis de corrigir quando já estruturadas (LE BOULCH, 1987, p. 11).

Como exposto acima, Le Boulch (1987) atribui a educação psicomotora na primeira infância como uma competência básica, principalmente na educação infantil. Pois é neste momento em que o indivíduo passa a possuir consciência sobre o seu corpo e movimentos. Corroborando com este pensamento, Negrine (1995), defende que, deve haver uma educação voltada para o desenvolvimento psicomotor da criança, e ela deve ser estimulada através de jogos e brincadeiras, levando em consideração a individualidade e a singularidade infantil. Com isto, a criança consegue ampliar a sua motricidade.

Neste parâmetro, a partir do momento em que a criança passa a relacionar-se socialmente e interagir com as pessoas a sua volta, consequentemente, passa a desenvolver melhor as suas expressões com este intermédio. Assim sendo, a sua relação com o meio social poderá influenciar diretamente em seu desenvolvimento psicomotor. Partindo dessas analises, Negrine (1995), retrata que a criança diante do convívio social, pode aprender alguns movimentos corporais.

Diante das observações acima expostas, ao fazer uma análise referente a educação psicomotora é importante mencionar que ela deve ocorrer através de uma parceria entre a família e a escola. Perante estas exposições, é significativo relatar que a psicomotricidade deve ser mediada através de jogos e brincadeiras, pois esta será fonte de prazer para a criança, e lhe permitirá o aprimoramento do seu desenvolvimento global. Neste sentido, Fonseca (2004) destaca:

A educação psicomotora pode ser vista como preventiva, na medida em que dá condições à criança desenvolver melhor em seu ambiente. É vista também como reeducativa quando trata de indivíduos que apresentam desde o mais leve retardo motor até problemas mais sérios. É um meio de imprevisíveis recursos para combater a inadaptação escolar (FONSECA, 2004, p. 10). 
Como exposto acima, Fonseca (2004) atribui a educação psicomotora como preventiva. Ou seja, ela pode prevenir alguns distúrbios. É através das práticas pedagógicas com um olhar voltado para a psicomotricidade que os profissionais da educação podem ajudar o aluno a evoluir no aspecto psicomotor. Vayer, (1984) descreve que as ações corporais, e a forma pela qual a criança utiliza para expressar-se poderão aperfeiçoar o desenvolvimento global e na formação da personalidade.

\section{A REEDUCAÇÃO PSICOMOTORA}

A psicomotricidade é importante para o desenvolvimento intelectual e cognitivo de uma pessoa. Tornando-se assim, fundamental para o processo de aprendizagem, principalmente na educação infantil, para que a criança consiga desenvolver-se amplamente em seus aspectos físicos e mentais. Diante disto, é primordial que, em alguns casos aconteça uma reeducação psicomotora. Neste seguimento, Le Bouch (1982) ressalta que:

A psicomotricidade tem nascido nos serviços de neuropsiquiatria infantil com o nome de reeducação psicomotora. Sua imagem inicial está ligada à patologia. Atualmente, uma corrente educativa tem se superposto à prática inicial (LE BOUCH, 1982, p. 22).

Neste sentido, Le Bouch (1982) diz que é primordial que uma criança tenha um acompanhamento voltado para sua reeducação psicomotora. Corroborando com este pensamento, Meur e Staes (1989, p. 23), olhar o nome dos autores "A reeducação psicomotora deve começar o mais cedo possível: quando mais nova for à criança sob nossa responsabilidade, menos longa será a reeducação." Ou seja, é primordial que a os docentes tenham conhecimentos na área da psicomotricidade, para que, ofereçam um suporte prático à criança.

Além de possuir conhecimentos sobre as práticas pedagógicas que auxiliem no desenvolvimento psicomotor de uma criança, o professor deve ter conhecimentos teóricos sobre a área, pois não adiantaria conhecer os jogos e brincadeiras que oportunizam o desenvolvimento global da criança sem saber aplicálo de forma significativa. Nesta perspectiva Lapierre (2002) diz que:

Nós deveríamos levar mais longe essa lógica; se a criança tem deficiências que a impedem de chegar ao cognitivo, é porque o ensino que recebeu não respeitou as etapas de seu desenvolvimento psicomotor. Sob o aspecto da prevenção, passaríamos da reeducação à educação psicomotora. Portanto, torna-se importante estudar as funções psicomotoras, bem como sua importância para o desenvolvimento infantil. (LAPIERRE, 2002, p. 25)

Segundo o autor, se a criança não estiver recebendo estímulos que a auxilie e propicie desenvolvimento na sua motricidade, ela poderá adquirir dificuldades intelectuais. É importante que, o educador atenda a todas as necessidades do aluno. Para que se necessário ele propicie ao aluno uma vivencia de reeducação psicomotora, para que a criança consiga expandir as suas habilidades motores.

É importante que os profissionais da educação conheçam as necessidades dos seus alunos para que diante dessas analises consigam elaborar de forma significativa um planejamento relevante em relação á necessidade da criança. Nesta perspectiva, Le Boulch (1983, p. 13) fala sobre a educação psicomotora: “[...] assegura o desenvolvimento funcional tendo em conta possibilidades da criança e ajuda sua afetividade a expandir-se e a equilibrar-se através do intercâmbio com o ambiente humano". Ou seja, através de uma reeducação psicomotora a criança poderá melhorar a sua forma de se relacionar com as outras pessoas.

A reeducação psicomotora viabiliza possibilitar um individuo a evoluir através de jogos e brincadeiras simbólicas, aos alunos vivenciarem oportunidades que estimulem o desenvolvimento psicomotor. É importante salientar que oportunizando uma criança a se expressar vai estimulá-la a construir sua própria autonomia e a sua autoconfiança. Neste sentido, Lapierre e Lapierre (2002) ressaltam que:

Todas as crianças guardam em si essas fantasias esses desejos agressivos, mas para que possam exprimí-los é preciso que o adulto os compreenda e os aceite. As tensões agressivas vão então se resolver num jogo que se tornará cada vez mais simbólico, e a criança vai por isso adquirir progressivamente uma independência que não é submissão cega nem oposição sistemática, mas aceitação ponderada, procura de um 
compromisso e, se possível, de uma harmonização entre seus próprios desejos com os desejos do outro (LAPIERRE; LAPIEERE, 2002, p. 67).

Neste sentido, segundo os autores Lapierre e Lapierre (2002), as crianças sentem dificuldades em se expressar e é necessário que elas convivam com um adulto que a entenda para que elas possam aprimorar sua motricidade. É de suma importância que os professores saibam intervir nas relações entre os alunos, com o objetivo de ajudar a fortalecer suas relações com os outros educandos.

A reeducação psicomotora pode acontecer por intermédio da psicopedagogia, com profissionais especialistas na área. Através dela é possível analisar melhor o individuo para detectar a sua necessidade motora por intermédio de reflexões realizadas por meio da observação das necessidades individuais de cada aluno. Partindo desses princípios, Sisto (1996) fala referente ao psicopedagogo que:

A psicopedagogia implica também, uma metodologia específica de trabalho. Essa metodologia precisa levar em conta, necessariamente o contexto em que se encontra a ação pedagógica: família, escola, comunidade. No caso da instituição de educação infantil, é preciso levar em conta não apenas as características dos educadores e da própria instituição (SISTO, 1996, p. 209).

Segundo Sisto (1996), os estudos realizados por intermédio de um psicopedagogo devem levar em consideração todos os contextos pelo qual o aluno está inserido, como: o social e cultural. Para a partir disso, este profissional da educação elabore meios de intervenções que sejam significativas para o educando de acordo com as suas especificidades. Para isto é necessário que o profissional de educação possua uma base teórica de autores que abordem este tema para convergir à prática com a teoria.

A infância é uma das fases mais importantes para o desenvolvimento cognitivo e afetivo do ser humano. Assim, é neste período em que o indivíduo possui dificuldades em relacionar-se com os demais. E é através do relacionamento da criança com os outros e com ela mesma que ela conseguirá uma maturação psicomotora. Portanto, é necessário um olhar sensível para estas situações objetivando uma intervenção significativa. Nesse sentido, Bueno (1998) diz que:

É nesse período que se instalam as principais dificuldades em todas as áreas de relação com o meio ao qual está inserido e que, se não forem exploradas e trabalhadas a tempo, certamente trarão prejuízos como dificuldades na escrita, na leitura, na fala, na sociabilização, entre outros. [...] Observando o indivíduo de forma global, a psicomotricidade faz-se necessária tanto para a prevenção e tratamento das dificuldades quanto para a exploração do potencial ativo de cada um (BUENO, 1998, p. 51).

Como foi descrito por Bueno (1998), se a criança não possuir acesso a uma educação que vise o seu desenvolvimento psicomotor, ela poderá desenvolver distúrbios cognitivos e emocionais. Assim sendo, em casos específicos é fundamental que um indivíduo passe pelo processo de uma reeducação psicomotora como forma de tratar e prevenir possíveis distúrbios no indivíduo.

Na sala de aula é fundamental que o educador faça uma reflexão sobre as suas próprias práticas no intuito de criar métodos que auxiliem os alunos a exteriorizar os seus pensamentos e suas emoções para assim, conseguir propor aos educandos praticas que permitam a eles desenvolvimento nas noções psicomotricas de forma saudável. Nesse sentido, Le Boulch (1983) diz que:

Com sua "atitude não diretiva" o educador, ao garantir uma certa gratuidade e liberdade no decorrer do jogo, facilitará para a criança a sua experiência do corpo, indispensável para a emergência das funções mentais e para seu desenvolvimento social (LE BOULCH, 1983, p. 50).

De acordo com Le Boulch (1983), a reeducação psicomotora deverá ocorrer através de jogos e Brincadeiras que permitam a liberdade do aluno em um aspecto integral. Através destas ações os aducandos poderão socializar melhor e desenvolver uma maturidade emocional de forma mais significativa. Desse modo, o aluno conseguirá através da ludicidade expressar-se de forma integral.

\section{RESULTADOS E DISCUSSÃO}

Na nossa coleta de dados bibliograficos, encontramos autores que colaboram com a nossa idéia, no sentido que, acreditam na importancia da psicomotricidade, bem como, o papel dos profissionais da educação 
nesta aréa cognitiva e corporal da criança. Sendo este pensamento, teorizado por Fonseca (1988), Le Boulch (1987), Oliveira (2000). Assim, ficou evidente a necessidade de expor esta temática mediante o cenário educativo nacional.

Fonseca (1988) trouxe para o nosso trabalho um viés histórico e antropológico acerca da psicomotricidade e a sua contribuição para a educação infantil. Sendo assim, serviu de base para a compreensão do campo psicomotor. Além disso, o autor explana de uma maneira cronológica as pesquisas existentes referentes à psicomotricidade, dando assim, embasamento e norteando o presente estudo.

Le Boulch (1987) forneceu à psicomotricidade extrema relevância perante as crianças. 0 autor externa a importância dos estímulos psicomotores na fase inicial da vida humana. Neste sentido, ficou nítido a contribuição do seu pensamento e, sobretudo, a sua atuação no ambiente escolar nas etapas primárias da educação básica. Com isso, evidenciou também, uma considerável influência na presente pesquisa.

\section{CONSIDERAÇÕES FINAIS}

Como observado no desenvolvimento deste trabalho, a psicomotricidade é fundamental para o processo evolutivo no âmbito cognitivo e global da criança. Neste aspecto, foi importante a realização desta pesquisa no sentido que, durante o seu percurso metodológico observou-se uma notória relevância desta temática na seara dos estudos das práticas pedagógicas.

Ainda no decorrer deste trabalho, ficou evidente que são poucos os profissionais da área da educação que são especialistas na área do desenvolvimento psicomotor das crianças, e estes são fatores prejudiciais para o desenvolvimento cognitivo e corporal da criança, principalmente em seus primeiros anos de vida. Pois se o professor em sala de aula não proporcionar momentos pelos quais o aluno se expresse dentro do espaço em que ele está inserido prejudicará o desenvolvimento do aluno.

Em um parâmetro educacional, percebeu-se que é de extrema importância a psicomotricidade para o desenvolvimento infantil, tanto no ambiente escolar quanto no viés familiar. Sendo assim, essa convergência entre ambos os locais é essencial para a evolução psicomotora infantil. Em contrapartida, caso haja dificuldade no desenvolvimento cognitivo, emocional e físico da criança, será necessário que ela passe por um processo de reeducação psicomotora.

Nesta pesquisa, também notamos a importância do educador no processo inicial da educação infantil. Sendo esse profissional essencial na evolução psicomotora do aluno, bem como, na descoberta de possíveis patologias do estudante e também a sua contribuição para o desenvolvimento do aluno em seus primeiros anos devida numa perspectiva motora e cognitiva.

Em suma, é evidente a importância dos profissionais da área da educação possuir conhecimentos voltados para o desenvolvimento psicomotor de uma criança. Tendo em vista da escassez de especialistas nesta área psicopedagógica. Assim sendo, evidenciamos a necessidade existente em estudar esta temática, bem como, a sua relevância para os professores se especializarem nesta área.

\section{REFERÊNCIAS}

[1] ALVES, F. Psicomotricidade: corpo, ação e movimento. 4. Ed. Rio de Janeiro: Wak, 2008.

[2] __ Fátima. Psicomotricidade: corpo, ação e emoção. 4. ed. Rio de Janeiro: Wak, 2008.

[3] ARAÚJO, Vânia Carvalho de. O jogo no contexto da educação psicomotora. São Paulo: Cortez, 1992.

[4] Associação Brasileira de Psicomotricidade. 1999. Disponível em: <http://www. psicomotricidade.com.br/apsicomotricidade.htm>. Acesso em: 10 Agost.. 2020.

[5] BRASIL. Referencial Curricular Nacional para a Educação Infantil /Ministério da Educação e do Desporto, Secretaria de Educação Fundamental. — Brasília: MEC/SEF, 1998.

[6] BUENO, Jocian Machado. Psicomotricidade: teoria e prática. São Paulo: Lovise, 1998.

[7] DE MEUR, A.; STAES, L. Psicomotricidade, Educação e Reeducação. Trad. Ana Maria Izique Galuban; Setsuko Ono (trad.). São Paulo: Manole Ltda, 1984.

[8] __ A.; STAES, L. Psicomotricidade, Educação e Reeducação: níveis maternais e infantis. Ana Maria Izique Galuban e Setsuko Ono (trad.). São Paulo: Manoel, 1989. 
[9] __ _ A.; STAES, L. Psicomotricidade: educação e reeducação. São Paulo: Manole, 1991.

[10] FILHO, Audir Bastos; SÁ, Claúdia Ferreira de. Psicomovimentar . São Paulo: Editora Papiru, 2001.

[11] FONSECA, V. da. Psicomotricidade. São Paulo: Martins Fontes, 1988.

[12] ___ V. da. Contributo para o estudo da Gêneses da Psicomotricidade. 3. ed. Lisboa: Editora Notícias, 1981.

[13] _ V. da. Psicomotricidade: perspectivas multidisciplinares. Porto Alegre:Artmed, 2004.

[14] _— Vitor. Psicomotricidade. 2ª

[15] GALLAHUE, David L; OZMUN John C. Compreendendo o desenvolvimento motor: bebês, crianças, adolescentes e adultos. 2. ed. São Paulo: Phorte, 2005.

[16] KISHIMOTO, T. M. A LDB e as Instituições de Educação Infantil: desafios e perspectivas. Revista Paulista de Educação Física,São Paulo, n.4, p. 7-14, 2001.

[17] KYILLOS, Michel Habib mosnteiro; SANCHES, Tereza Leite. Fantasia e criatividade no espaço lúdico educação física e psicomotricidade. In: ALVES, Fátima (org). Como aplicar a psicomotricidade- uma atividade multidisciplinar com amor e união. Rio de Janeiro: Wak, 2004.

[18] LAPIERRE, A., LAPIERRE, A. 0 adulto diante da criança de 0 a 3 anos: psicomotricidade relacional e formação da personalidade. Tradução de Maria Ernatina G. G. Pereira. 2. Edição Curitiba: UFPR/CIAR, 2002.

[19] LE BOUCH, J. Educação psicomotora: psicocinética na idade escolar. Porto Alegre: Artes médicas, 1987. 11p.

[20] _ J. O desenvolvimento psicomotor: do nascimento até 5 anos. Porto Alegre: Artes Médicas, 1982.

[21]__ Jean. A educação pelo movimento: a psicocinética na idade escolar. Porto Alegre: Artes Médicas, 1983.

[22] MENDONÇA, Raquel Marins de. Criando o ambiente da criança: a psicomotricidade na educação infantil. In: ALVES, Fátima. Como aplicar a psicomotricidade: uma atividade multidisciplinar com amor e união. Rio de Janeiro: Wak, 2004. p.19-34.

[23] Negrine, Airton. Aprendizagem e desenvolvimento infantil: psicomotricidade: alternativas pedagógicas. Porto alegre: Prodil, 1995.

[24] _ _ o corpo na educação infantil. Caxias do Sul, EDUCS, 2002.

[25] OLIVEIRA, Vera Barros de (org). O brincar e a criança do nascimento aos seis anos. Petrópolis, RJ: Vozes, 2000.

[26] SISTO, Firmino Fernandes. Atuação psicopedagógica e aprendizagem escolar. Petrópolis/RJ: Vozes, 1996.

[27] VELASCO, Cassilda Gonçalves. Brincar: O Despertar Pscicomotor. Rio de Janeiro: Sprint,1996.

[28] WALLON, H. As origens do caráter na criança. São Paulo: Nova Alexandria, 1995. 


\section{Capítulo 11}

Cultura corporal e Educação Infantil na perspectiva histórico-cultural e histórico-crítica

\section{Rafael Oliveira de Antonio}

Resumo: A cultura corporal se constitui nas diferentes manifestações do corpo e movimento, transcende a visão simplista de motricidade e se estabelece como uma produção humana corpórea transformada em patrimônio cultural, externando o jogo, a ginástica, a luta, o esporte e a dança. Nessa perspectiva, ela integra os conhecimentos basilares da educação infantil, considerando a formação omnilateral do indivíduo. No entanto, investigações incipientes na área, visões equivocadas acerca do que vem a ser cultura corporal - domínio motor e brincadeiras - acabam renegando esse conhecimento desde a tenra idade. Dentro dessa problemática, a concepção históricocultural e histórico-crítica se torna referência nuclear para mediar o diálogo entre cultura corporal e educação infantil. 0 objetivo do estudo se voltou para a possibilidade de ressignificar e ampliar o conceito de motricidade na educação infantil, por meio da cultura corporal, a partir de uma perspectiva histórico-cultural e histórico-crítica. Para tanto, a investigação foi fundamentada no método materialista histórico-dialético, sendo a metodologia desenvolvida baseada em uma pesquisa teórica, de natureza exploratória e abordagem qualitativa. Como resultado, observamos um entendimento equivocado de prática corporal - reducionista e biologizante, o que corrobora em associar a educação física escolar com seu histórico esportivista ou mera recreação, se distanciando dos conteúdos da cultura corporal. Assim, defendemos a necessidade da inserção da cultura corporal desde a educação infantil, sob a perspectiva histórico-cultural e históricocrítica, proporcionando conhecer a gênese do movimento, sua estruturação e as inevitáveis contradições, convertendo-se em uma prática autônoma ao longo da vida.

Palavra-chave: Cultura Corporal, Educação Infantil, Pedagogia Histórico-Cultural, Pedagogia Histórico-Crítica 


\section{INTRODUÇÃO}

Ao longo da história a educação infantil tem sido vista pelo prisma do assistencialismo - substituir os cuidados do lar - se distanciando do seu propósito educativo como primeira etapa da educação básica. Embora as crianças dessa fase tenham necessidade fisiológicas e emotivas, sem as quais não sobreviveriam, essa imagem deturpada culminou em sua subalternidade frente aos demais segmentos educacionais e, consequente, perda de identidade própria. Ainda que o educar e o cuidar sejam dimensões indissociáveis da práxis pedagógica infantil (BRASIL, 2006), é inaceitável imperar essa postura antiescolar.

A cultura corporal, objeto de estudo da educação física, vive situação análoga quando observamos divergências entre programas curriculares e sua atuação tímida ou praticamente irrelevante na educação infantil. Fato este ilustrado na prática pedagógica, em sua maioria, delegada a professores generalistas, que muitas vezes apresentam uma concepção equivocada de prática corporal, resume à brincadeira de parque e cirandas - destituídas de qualquer planejamento ou especificidade educacional (EHRENBERG, 2014). Desse modo, essa abordagem espontaneísta apesar de entreter, divertir e socializar, acaba levando a uma atitude de laissez-faire - abandono pedagógico, descaracterizando a área e seu contributo no conhecimento relativo à cultura corporal.

No contexto escolar, a educação física superou diferentes concepções históricas: higienista, militarista, pedagogicista, competitivista e popular (GHIRALDELLI JÚNIOR,1988), para fundamentar seu conhecimento na cultura corporal, que simboliza uma produção humana corpórea transformada em patrimônio cultural, e externada nas diferentes manifestações do jogo, da ginástica, da luta, do esporte e da dança (COLETIVO DE AUTORES, 2012). Esse Coletivo defende a abordagem crítico-superadora, que considera a categoria cultura corporal como objeto de estudo próprio da educação física. Tal teoria tem sua fundamentação filosófica no materialismo histórico-dialético, abrangendo a dialética do corpo e redefinindo exercício físico e movimento - superar a biologicidade da área.

0 ensino da cultura corporal, por sua vez, busca ressignificar e ampliar o conceito de motricidade na educação infantil, tendo como arcabouço teórico a perspectiva histórico-crítica e histórico-cultural. Esta pautada na historicidade humana e na cultura como constituidoras do psiquismo, e aquela defendendo a especificidade da escola e do trabalho do professor na transmissão do conhecimento sistematizado historicamente acumulado. Sendo assim, será possível formar o indivíduo, desde a infância, enquanto sujeito histórico, crítico e consciente da realidade social em que vive, baseado em uma formação omnilateral e realize aquilo que a própria legislação aponta como ideal:

Art. 29. A educação infantil, primeira etapa da educação básica, tem como finalidade o desenvolvimento integral da criança de até 5 (cinco) anos, em seus aspectos físico, psicológico, intelectual e social, complementando a ação da família e da comunidade. (BRASIL, 2017, p. 20).

Para a abordagem crítico-superadora, portanto, a capacidade física ou habilidades motoras se constituem apenas como elementos de ensino, e não seu objetivo último. Já os conhecimentos humano-genéricos produzidos na atividade da cultura corporal se configuram como um corpo de conhecimentos próprios da educação física, ou seja:

0 homem se apropria da cultura corporal dispondo sua intencionalidade para o lúdico, o artístico, o agonístico, o estético ou outros, que são representações, idéias, conceitos produzidos pela consciência social e que chamaremos de "significações objetivas". Em fase delas, ele desenvolve um "sentido pessoal" que exprime sua subjetividade e relaciona as significações objetivas com a realidade da sua própria vida, do seu mundo e das suas motivações (COLETIVO DE AUTORES, 2012, p. 62).

Diante de toda essa problemática, a concepção histórico-cultural e histórico-crítica se torna referência nuclear para mediar o diálogo entre cultura corporal e educação infantil. Para tanto, a escola infantil é palco desse processo, permitindo o acesso ao conhecimento humano mais desenvolvido desde a tenra idade. Ademais, uma organização curricular é desejável, assim como propõe Pasqualini (2018) ao destacar a cultura corporal como uma das grandes áreas integrantes da matriz curricular da educação infantil. Por fim, tomar o currículo com base na psicologia histórico-cultural proporciona identificar os conteúdos e formas de ensino pautadas na atividade-guia de cada etapa da periodização do psiquismo da criança (DUARTE; SAVIANI, 2019). 
Com referência aos inúmeros argumentos expostos até o momento, o objetivo desta investigação foi ressignificar e ampliar o conceito de motricidade na educação infantil, por meio da cultura corporal, a partir de uma perspectiva histórico-crítica e histórico-cultural.

\section{MATERIAIS E MÉTODOS}

0 presente estudo foi fundamentado no método materialista histórico-dialético. Já a metodologia desenvolvida se baseou em uma pesquisa teórica, de natureza exploratória e abordagem qualitativa. Partimos da seleção do acervo literário a ser apreciado como campo material de análise, delimitamos a pesquisa de forma objetiva nas ideias das obras consultadas, comparamos e confrontamos os autores em foco. Para finalmente chegarmos a uma síntese sobre a investigação conduzida.

\section{RESULTADOS E DISCUSSÃO}

Na literatura pesquisada, observamos um entendimento equivocado de prática corporal - reducionista e biologizante, o que corrobora para associar a educação física escolar com seu histórico de aulas reproduzindo um modelo esportivista (DAOLIO, 1999) ou mera recreação, entendendo essa disciplina até mesmo como inadequada para a educação infantil. Assim, a cultura corporal se mostra como desconhecida para esse segmento de ensino, no qual prevalece apenas a ideia de moticidade - desenvolvimento motor atividades recreativas ou brincadeiras de parque.

Já o embate acerca de qual profissional seria o mais adequado para trabalhar a cultura corporal na educação infantil, embora não tenha sido o propósito deste estudo, é um assunto recorrente na área. Freire (2006) expõe duas vertentes: de uma lado, há os que defendem a inclusão de um professor especialista para ministrar as aulas, do outro lado, temos os que advogam pela estrutura atual, alegando ser melhor para a criança o contato apenas com o professor generalista - menor risco de fragmentação do conhecimento. Como se fosse possível preservar a criança do contato com saberes além dos muros da escola, seja no seio familiar, nos meios de comunicação, ou simplesmente propagados pela web e amigos.

Na esteira desse pensamento, independentemente de quem transmita o conteúdo da cultura corporal, desde que tenha domínio desse conhecimento, o mais importante é não privar a criança de todo esse patrimônio histórico, visando uma formação plena.

\section{CONSIDERAÇÕES FINAIS}

Quando propomos, a partir do referencial histórico-cultural e histórico-crítico, a incorporação da cultura coporal no currículo da educação infantil, estamos indicando algo além do desenvolvimento motor e da recreação. 0 conhecimento histórico englobado pela cultura corporal é muito rico para deixar de fazer parte da escola infantil. Conhecer a gênese, evoluções e ressignificações dessas representações do corpo e movimento, desde o ingresso no ensino básico, é construir um legado para a adolescência e vida adulta.

Também é relevante dizer sobre a necessidade de novas pesquisas sobre cultura corporal e educação infantil, complementando e reestruturando vários assuntos que trouxemos à baila com este estudo.

\section{AGRADECIMENTOS}

O presente trabalho foi realizado com apoio da Coordenação de Aperfeiçoamento de Pessoal de Nível Superior - Brasil (CAPES) - Código de Financiamento 001. 


\section{REFERÊNCIAS}

[1] BRASIL. Ministério de Educação e do Desporto. Secretaria de Educação Básica. Política Nacional de Educação Infantil: pelo direito das crianças de zero a seis anos à educação. Brasília, DF: 2006.

[2] BRASIL. Ministério de Educação e Cultura. LDB: Lei de diretrizes e bases da educação nacional. Brasília, DF: Senado Federal, Coordenação de Edições Técnicas, $2017 . \quad$ Disponível em: http://www2.senado.gov.br/bdsf/item/id/529732. Acesso em: 10 ago. 2020.

[3] COLETIVO DE AUTORES. Metodologia do ensino de educação física. 2. ed. São Paulo: Cortez, 2012.

[4] DAOLIO, J. A cultura do corpo. 4. ed. Campinas: Papirus, 1999.

[5] DUARTE, N.; SAVIANI, D. Entrevista com o professor Dermeval Saviani "Pedagogia Histórico-Crítica na atualidade". Colloquium Humanarum, v. 16, n. 2, p. 4-12, jul. 2019.

[6] EHRENBERG, M. C. A linguagem da cultura corporal sob o olhar de professores da educação infantil. ProPosições, Campinas, v. 25, n. 1, p. 181-198, jan./abr. 2014.

[7] FREIRE, J. B. Educação de corpo inteiro: teoria e prática da educação física. 4. ed. São Paulo: Scipione, 2006.

[8] GHIRALDELLI JÚNIOR, P. Educação Física progressista: a pedagogia crítico-social dos conteúdos e a Educação Física brasileira. São Paulo: Loyola, 1988.

[9] PASQUALINI, J. C. Proposta curricular para a educação infantil: a experiência de Bauru-SP. Revista Espaço do Currículo, João Pessoa, v. 11, n. 2, p. 154-167, mai./ago. 2018. 


\section{Capitulo 12}

\section{A metacognição no ensino de língua portuguesa: Proposta de sequência didática a partir dos gêneros}

\section{Flaviana América Silva Dantas de Souza \\ Mirtes Ribeiro de Lira}

Resumo : 0 ensino de língua portuguesa no Brasil passou por várias transformações e, mesmo após muita pesquisa e discussões a respeito, até os dias de hoje não se mostra eficiente o bastante. Uma breve análise é capaz de nos fazer perceber que as mudanças nas práticas pedagógicas impostas ou sugeridas no decorrer do tempo não conseguiram atender satisfatoriamente aos anseios de uma melhoria significativa nos índices educacionais medidos pelas avaliações externas. Diante do exposto, partimos da hipótese de que a realização de uma prática mais focada no ato comunicativo e a inserção de aspectos metacognitivos no ensino da língua portuguesa, especialmente nos estudos de gêneros de texto, resultariam em alterações metodológicas que influenciariam positivamente no processo de ensino-aprendizagem. Sendo assim, este artigo tem como objetivo apresentar uma nova proposta didática para o ensino da língua materna, tomando como eixos básicos o texto e a reflexão linguística, levando em consideração a importância da interação e da metacognição para a formação cidadã. Adotamos como base teórica para o desenvolvimento deste trabalho o Interacionismo Sociodiscursivo (IDS), os estudos feitos por Dolz, Noverraz e Schneuwly (2004) e por Flavell (1976). Optamos também por dialogar com os Parâmetros Curriculares Nacionais dos terceiro e quarto ciclos do Ensino Fundamental (1998) e com a proposta de grade programática de Antunes (2009). Baseadas nos estudos citados, desenvolvemos uma nova proposta de sequência didática, que apresentaremos no artigo, a qual acreditamos que também pode servir como modelo para estruturar a distribuição dos assuntos nas unidades didáticas que constituem os currículos de língua portuguesa.

Palavras-chave: gêneros de texto, metacognição, sequência didática, ensino de língua portuguesa 


\section{INTRODUÇÃO}

No período colonial, a língua portuguesa no Brasil não constava no currículo escolar. A constituição da disciplina se deu de forma lenta, iniciando em 1757 com algumas reformas impostas pelo rei de Portugal, o Marquês de Pombal. Foram instituídas reformas de estudos e a língua portuguesa passou a ser oficial, proibindo o uso de outras línguas, na época, utilizadas pela população.

Em 1838, a língua portuguesa, ainda a caminho da consolidação como disciplina escolar, passou a ser o principal objeto de ensino ministrado em aulas de Retórica e Poética. (PFROM NETO et al, 1974).

Durante os anos seguintes do século XIX, o ensino da língua portuguesa foi marcado por várias mudanças. Os recursos didáticos mais comuns na época eram uma gramática, um dicionário e uma coletânea de textos produzidos por autores portugueses e brasileiros. A metodologia, por sua vez, era pautada em exercícios de ortografia, leitura literária e recitação (RAZZINI, 2000).

Desse momento até a década de 1940 não houve modificações relevantes em relação ao ensino da língua portuguesa. As mudanças se intensificaram após a democratização do ensino, em 1950, com a chegada de um público que utilizava uma variação linguística bastante heterogênea e, portanto, ainda não abordada metodologicamente.

A consolidação da língua portuguesa no currículo ocorreu em 1960 quando houve a inclusão de exercícios de vocabulário, interpretação, redação e gramática nos materiais didáticos e a fusão da gramática com o livro de textos. No ano seguinte, a Linguística foi introduzida nos cursos de graduação em Letras, pois a variação linguística já estava sendo trabalhada nas escolas. Pouco tempo depois, a Lei de Diretrizes e Bases da Educação, Lei no 5.692/1971, intitulou o ensino de língua portuguesa na Educação Básica como uma disciplina chamada Comunicação e Expressão (SOARES, 2002).

Nos anos 1980, o estudo da Linguística Textual traz mudanças com relação ao eixo de ensino da língua que aos poucos vai deixando de ser a gramática para tomar o texto como suporte principal para o seu ensino. Os Parâmetros Curriculares Nacionais concretizam essa visão ao apresentar a língua como instrumento de interação, defendendo a utilização dos gêneros textuais como fortes aliados no processo de ensinoaprendizagem nas aulas de língua materna.

Nesse cenário, a busca pela formação de sujeitos capazes de exercer a cidadania de forma efetiva, resultou em um ensino que caminha no sentido de promover a construção de competências e habilidades básicas, em detrimento do acúmulo de esquemas resolutivos pré-definidos (PCNEM, 2000, p. 17). Segundo Travaglia (1998, p. 17), o principal objetivo do ensino de língua materna é desenvolver prioritariamente a competência comunicativa dos usuários da língua (falante, escritor/ouvinte, leitor).

Desse modo, o ensino de língua portuguesa no Brasil passou por várias transformações e até os dias de hoje não se mostra eficiente o bastante. Os resultados das avaliações externas do Sistema Nacional de Avaliação da Educação Básica (SAEB) e do Sistema de Avaliação da Educação Básica do Estado de Pernambuco (SAEPE), por exemplo, corroboram com essa afirmação ao revelarem que a proficiência em leitura dos estudantes da rede pública, em 2015, ainda está bem aquém do Padrão de Desempenho considerado ideal. Nesse sentido, podemos afirmar que muitas pesquisas ainda precisam ser desenvolvidas no intuito de mudar um quadro educacional ainda considerado crítico.

Portanto, todo e qualquer estudo desenvolvido deve levar em consideração a evolução do ensino da língua para que se possa compreender a situação atual. Uma breve análise é capaz de nos fazer perceber que as mudanças nas práticas pedagógicas impostas ou sugeridas no decorrer do tempo não conseguiram atender satisfatoriamente aos anseios de uma melhoria significativa nos índices educacionais medidos pelas avaliações externas.

Diante do exposto, partimos da hipótese de que a inserção dos aspectos metacognitivos no ensino da língua portuguesa, especialmente, nos estudos de gêneros, resultariam em alterações metodológicas significativas na prática pedagógica para a aprendizagem dos estudantes.

Sendo assim, este artigo tem como finalidade apresentar uma proposta didática para o ensino da língua materna, tomando como eixos básicos o texto e a reflexão linguística, levando em consideração a importância da interação e da metacognição. Adotamos como base teórica para o desenvolvimento deste trabalho o Interacionismo Sociodiscursivo (IDS), os estudos feitos por Dolz, Noverraz e Schneuwly (2004), Flavell (1976) e Portilho (2009). Optamos também por dialogar com os Parâmetros Curriculares Nacionais dos terceiro e quarto ciclos do Ensino Fundamental (1998). 


\section{A IMPORTÂNCIA DO INTERACIONISMO SOCIODISCURSIVO NA LÍNGUA PORTUGUESA}

Vários fatores influenciam na construção de qualquer atividade discursiva, como por exemplo o contexto histórico, social, finalidades, intenções, opiniões, convicções, além de outros fatores relacionados ao interlocutor (PCN, 1998). Essa é a visão do Interacionismo Sociodiscursivo (doravante ISD), corrente teórica desenvolvida por Jean-Paul Bronckart e inspirada em estudos realizados no campo do Interacionismo Social com enfoque em trabalhos realizados por Vygotsky e Bakhtin e amplamente divulgada pelos pesquisadores da Universidade de Genebra vinculados à Unidade de Didática de Línguas da Faculdade de Psicologia e Ciências.

O ISD desenvolve a ideia de que a participação de aspectos psíquicos e sociais se complementam resultando na materialização da linguagem. Pois, segundo Bronckart (1999), as formações sociais são responsáveis pelo funcionamento permanente da atividade de linguagem resultante em diferentes espécies de textos, nomeadas de gêneros de textos, que apresentam características relativamente estáveis e ficam "disponíveis no intertexto como modelos indexados", para as gerações atuais e posteriores. Nesse sentido, para o autor "a apropriação dos gêneros é um mecanismo fundamental de socialização, de inserção prática nas atividades comunicativas humanas" (1999, p. 103) e as condutas humanas são consideradas como "ações situadas cujas propriedades estruturais e funcionais são, antes de mais nada, um produto de socialização" (1997, p.13).

Numa visão bakhtiniana, a nossa comunicação se dá por meio dos gêneros textuais que são materializados de acordo com três dimensões essenciais: os conteúdos transmitidos; as particularidades estruturais de cada gênero; e as configurações específicas das unidades de linguagens, especialmente, traços da posição enunciativa do enunciador, e os conjuntos particulares de sequências textuais e de tipos discursivos que formam sua estrutura.

Não é possível quantificar os gêneros textuais, pois eles podem aparecer, desaparecer, variar ou, até mesmo, evoluir de acordo com o meio de produção, a época ou as necessidades dos falantes. Embora as manifestações discursivas se materializem em diferentes formas de enunciados, dependendo de sua estrutura, tipo de linguagem, conteúdo ou algum outro ponto em comum, podemos diferenciá-las e classificá-las em um gênero de texto específico. Segundo Bakhtin, "qualquer enunciado considerado isoladamente é, claro, individual, mas cada esfera de utilização da língua elabora seus tipos relativamente estáveis de enunciados, sendo isso que denominamos gêneros do discurso" $(2000$, p. 279 , destaques do autor).

Dolz e Schneuwly (2004), ao tratar de gênero de texto, afirmam que gênero pode ser considerado como instrumento ou "megainstrumento" que permite realizar ações em situações particulares. Esses autores classificam-no, ainda, como instrumento semiótico complexo constituído de signos organizados de maneira regular que compreende níveis diferentes. Passarelli (2012, p. 125), por sua vez, conceitua gênero textual como sendo qualquer "realização linguística concreta definida por propriedades sociocomunicativas" e acrescenta, ainda, que a produção de um texto concretiza-se por meio da modalidade oral ou escrita, cumprindo objetivos preestabelecidos.

A partir das afirmações dos teóricos supracitados, defendemos que o ensino de Língua Portuguesa não deve estar distante da realidade do estudante. Pelo contrário, situações devem ser criadas para que haja a necessidade da compreensão/produção dos textos num cenário que se aproxime ao máximo da realidade social de todos os envolvidos no processo de ensino-aprendizagem.

Os PCN (1998) apresentam o uso da língua oral e escrita e a reflexão sobre a língua e a linguagem como os eixos básicos que articulam o ensino de língua portuguesa. Segundo Antunes (2009, p. 49), usar a linguagem é uma forma de agir socialmente, de interagir com os outros e essas coisas somente acontecem em textos. Nesse sentido, o estudo da língua deve ter como referência os gêneros textuais (Bronckart, 2006) ou discursivos (Bakhtin, 2000), como podemos observar na imagem a seguir. 
Figura 1 - Eixos de ensino da língua

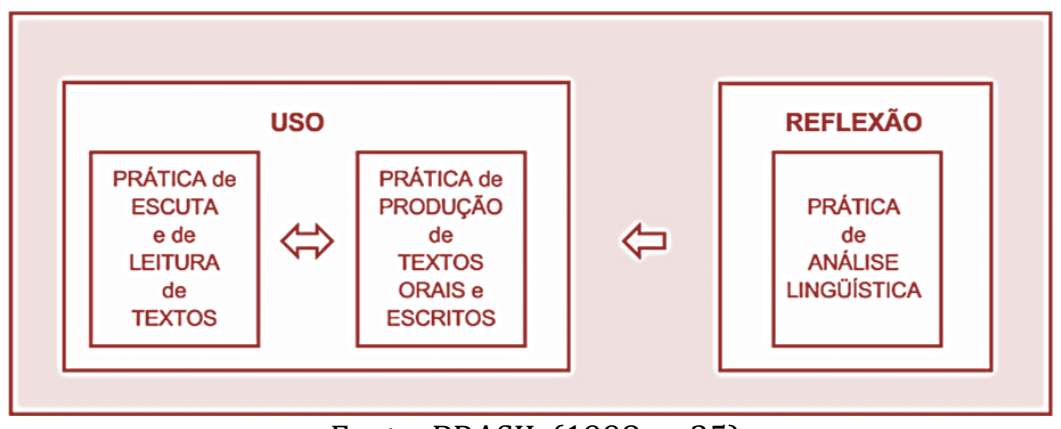

Fonte: BRASIL (1998, p. 35)

Ambos os eixos, recomendados pelos PCN, sustentam-se na prática interacionista sociodiscursiva da linguagem, pois levam em consideração a reflexão do estudante sobre sua própria fala ou escrita em situações de uso, ou seja, de interação, buscando articular o ensino a contextos reais de comunicação. Seguindo a referida vertente teórica, ainda podemos destacar um recorte do PCN (1998, p. 24) que versa sobre o uso de textos ao afirmar que

é preciso que as situações escolares de ensino de Língua Portuguesa priorizem os textos que caracterizam os usos públicos da linguagem. Os textos a serem selecionados são aqueles que, por suas características e usos, podem favorecer a reflexão crítica, o exercício de formas de pensamento mais elaboradas e abstratas, bem como a fruição estética dos usos artísticos da linguagem, ou seja, os mais vitais para a plena participação numa sociedade letrada.

\section{ASPECTOS DA METACOGNIÇÃO NO ENSINO DA LÍNGUA PORTUGUESA}

A metacognição despontou por volta dos anos 1970 com o psicólogo americano John Hurley Flavell e intensificou-se entre os anos 80 e 90. Segundo o autor (1976), a metacognição envolve processos de monitoramento, avaliação, autorregulação e aprendizagem. Sendo assim, podemos considerar a metacognição como um processo fundamental para o desenvolvimento de uma aprendizagem significativa e a potencialização dos processos cognitivos.

A consciência do processamento cognitivo leva ao desenvolvimento de estratégias, ao controle de ações, a avaliação de uma atividade concluída, a percepção de fraquezas relacionadas a determinado tema, enfim, torna o indivíduo autônomo para buscar meios mais práticos e eficientes para se chegar aos objetivos pretendidos. Nesse sentido, Ribeiro (2003, p. 110) afirma que assim, como objeto de investigação e no domínio educacional encontramos duas formas essenciais de entendimento da metacognição: conhecimento sobre o conhecimento (tomada de consciência dos processos e das competências necessárias para a realização da tarefa) e controle ou autorregulação (capacidade para avaliar a execução da tarefa e fazer correções quando necessário - controle da atividade cognitiva, da responsabilidade dos processos executivos centrais que avaliam e orientam as operações cognitivas).

Percebe-se, portanto, um vínculo existente entre aprendizagem e metacognição. Pois, quem faz uso da metacognição consegue assimilar conhecimentos e aprender com mais agilidade e quem efetivamente aprende costuma desenvolver estratégias metacognitivas que além de facilitarem o processo de compreensão, consolidam as assimilações absorvidas.

Um novo modelo educacional surgiu no Brasil a partir da promulgação da Constituição de 1988 e a Lei de Diretrizes e Bases da Educação Nacional de 1996 (LDB). As práticas, até então, direcionadas ao ensino com foco no professor, passaram a ter a aprendizagem como essência do processo educacional, voltando, assim, a atenção para os estudantes.

A partir dessa nova realidade na educação brasileira, o estudante passou a ser o maior responsável pela sua aprendizagem, havendo a necessidade do desenvolvimento de estratégias de compreensão do processo metacognitivo nas aulas ministradas. Segundo Portilho (2009), a percepção de habilidades e fragilidades potencializa a aprendizagem, pois possibilita um planejamento estratégico mais adequado, tendo em vista que o sujeito tem consciência do que já sabe, do que precisa aperfeiçoar e dos caminhos mais apropriados para se atingir seus objetivos e metas. 
Nessa direção, Nickerson, Perkins e Smith (1994, apud PORTILHO, 2009, p. 107) corroboram com as colocações supracitadas ao expressar que a metacognição é o conhecimento sobre o conhecimento e o saber, incluindo o conhecimento das capacidades e das limitações dos processos do pensamento humano; do que se pode esperar que os seres humanos saibam em geral; e das características da pessoa em si, em especial, de si mesma como conhecedora e pensante. Esse conhecimento inclui a capacidade de planejar e regular o emprego eficaz dos próprios recursos cognitivos.

Em virtude do que foi observado, fica clara a importância da metacognição no ensino, objetivando o desenvolvimento e o aperfeiçoamento de processos cognitivos que levam o estudante a aprender a aprender, tornando-o protagonista de sua própria aprendizagem.

\section{ENSINO DA LÍNGUA PÓRTUGUESA - UMA PROPOSTA A PARTIR DOS GÊNEROS}

Dolz e Schneuwly (2004, p. 45) defendem que as intervenções que levam a uma melhor maestria dos gêneros e das situações comunicativas impostas pela sociedade aos estudantes devem partir de estratégias de ensino que forneçam instrumentos necessários para a progressão em atividades comunicativas complexas. Nesse sentido, os autores apontam as sequências didáticas como ferramenta norteadora de intervenções pedagógicas.

A finalidade de uma sequência didática é oportunizar, aos estudantes, o contato com práticas linguísticas complexas e, até então, desconhecidas por eles. Sua organização se dá em função de um gênero de texto, envolvendo atividades orais ou escritas sistematicamente organizadas. Sua estrutura basilar é apresentada pelos autores por meio do esquema mostrado a seguir.

Figura 2: Esquema de sequência didática

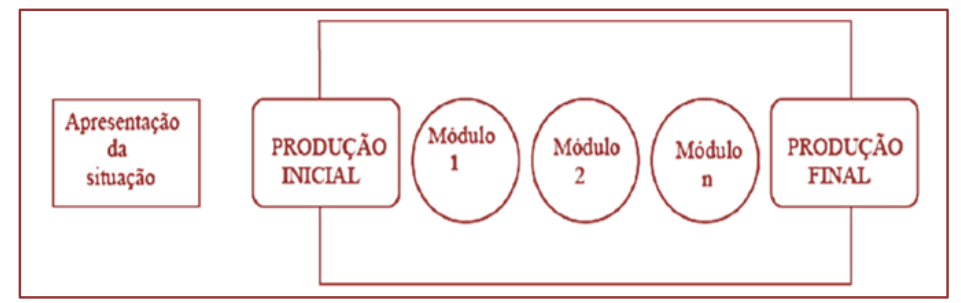

Fonte: Dolz, Noverraz e Schneuwly (2004, p. 83)

O esquema acima inicia com a "apresentação da situação", na qual a proposta de produção de um gênero é descrita pelo professor, levando em consideração o contexto de produção, incluindo o(s) interlocutor(es), suporte etc. Em seguida, objetivando um levantamento dos conhecimentos prévios dos estudantes acerca do gênero em questão, é solicitada uma "produção inicial" que será objeto de análise docente para o planeamento dos módulos que serão aplicados. Esses "módulos" ou oficinas consistem no desenvolvimento de atividades que envolvam as dificuldades observadas no textos produzidos anteriormente, visando a ampliação da compreensão dos estudantes sobre o referido gênero de texto. É importante salientar que o quantitativo de módulos dependerá do nível de entendimento da turma. Para finalizar esse modelo de sequência didática, será necessária a realização de uma "produção final" que servirá como objeto de investigação dos conhecimentos adquiridos no decorrer do processo.

É necessário também considerarmos as Matrizes de Referência das avaliações externas para a elaboração de quaisquer estratégias didáticas, em razão de os descritores que as constituem possibilitar uma abordagem mais específica das habilidades necessárias às atividades de leitura sem deixar de considerar aspectos específicos dos gêneros textuais em estudo, facilitando, assim, o trabalho do professor (MAGALHÃES, 2001).

O Instituto Nacional de Estudos e Pesquisas Educacionais Anísio Teixeira (INEP) deixa claro como foi produzido as Matrizes de Referência, como são estruturadas e sua importância para a elaboração dos itens das avaliações externas e, consequentemente, a verificação das habilidades desenvolvidas pelos estudantes por meio da análise das respostas aos itens.

Para elaborar as matrizes de referência, foi feito um recorte com base no que pode ser aferido por meio dos instrumentos utilizados no SAEB e na Prova Brasil. As matrizes de referência estão subdivididas em tópicos ou temas e estes, em descritores. Cada descritor é uma associação entre conteúdos curriculares e operações mentais desenvolvidas pelos alunos que traduzem certas competências e habilidades. Os descritores, portanto, especificam o que cada habilidade implica e são utilizados como base para a 
construção dos itens de testes das diferentes disciplinas. Cada descritor dá origem a diferentes itens e, a partir das respostas dadas a eles, verifica-se quais habilidades os alunos efetivamente desenvolveram (INEP).

Antunes (2009, p. 62-69), por sua vez, propõe uma grade programática para as séries iniciais do Ensino Fundamental a partir dos gêneros. Dolz, Noverraz e Schneuwly (2004, p. 106) também apresentam um quadro que, segundo os autores, pode servir como "possível organização de currículo". Nele, podemos observar que a estruturação do trabalho pedagógico parte de sequências didáticas acerca de gêneros de texto. Seguindo esse pensamento, portanto, podemos afirmar que as ideias expostas partem de um mesmo princípio, ter o gênero como unidade central do processo de ensino-aprendizagem.

Dessa forma, acreditamos que se as aulas de língua materna fossem estruturadas a partir dos textos e não dos eixos de ensino presentes nos Parâmetros Curriculares, como ocorre em diversas situações, as atividades acerca dos gêneros se tornariam mais detalhadas, consequentemente, os estudantes conseguiriam assimilar melhor as habilidades trabalhadas em sala de aula.

Baseadas nos estudos citados, principalmente no esquema de sequência didática proposto por Dolz, Noverraz e Schneuwly (2004, p. 83), e no que requer os PCN, pensamos em uma nova proposta de sequência didática, apresentada a seguir, a qual acreditamos que também poderia servir como modelo para estruturar as unidades didáticas distribuídas nos currículos de Língua Portuguesa.

Figura 3 - Estruturação de sequências didáticas

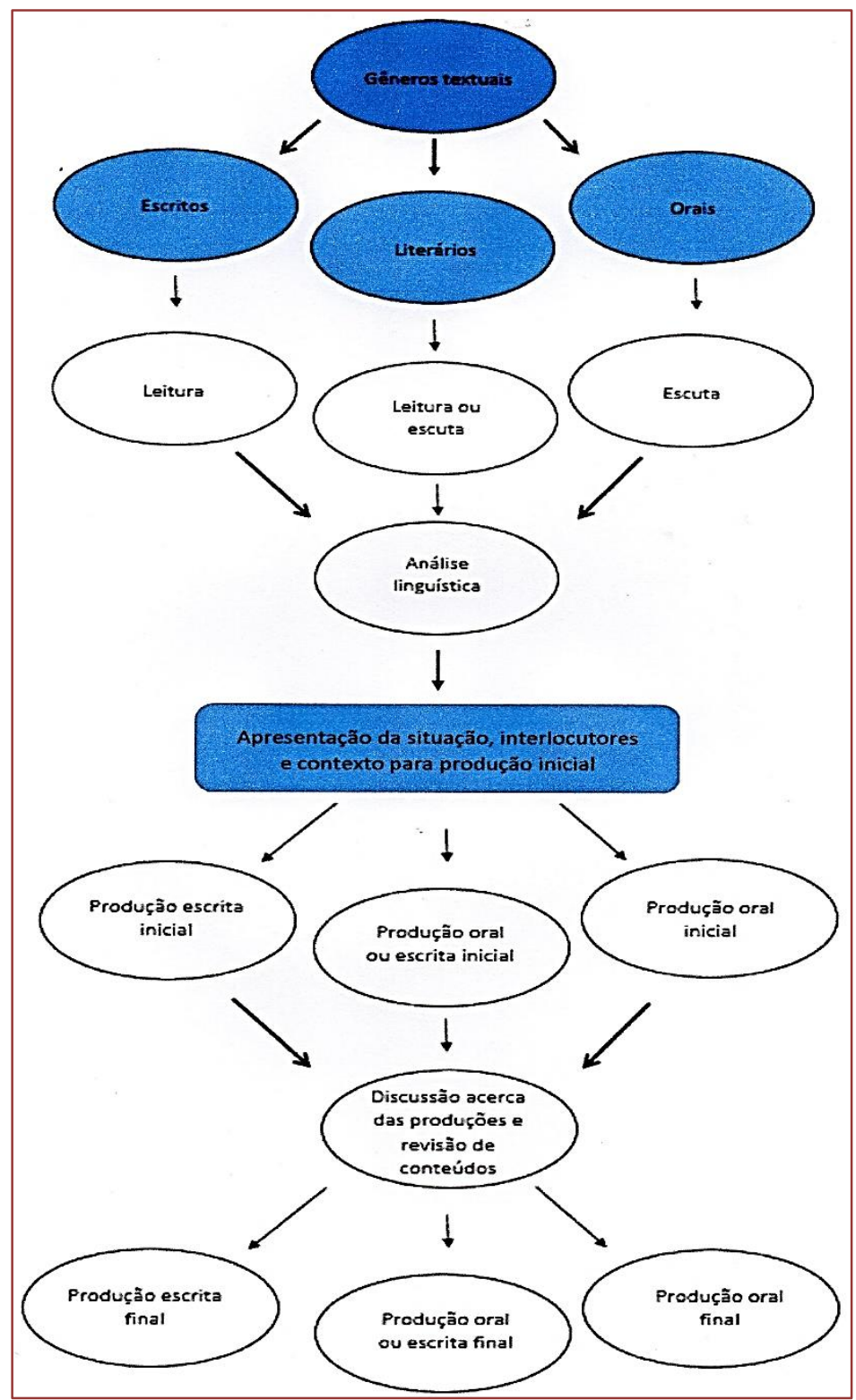


A partir dessa estrutura, acreditamos que os gêneros passariam a ser trabalhados meticulosamente, consequentemente haveria uma maior contribuição para o processo de letramento e uma melhor compreensão dos estudantes acerca das particularidades relacionadas aos textos, resultando na melhoria dos índices educacionais.

Dessa forma, tomando como paradigma os anos finais do Ensino Fundamental (6ㅇ ao 9o ano), quantitativamente, seriam trabalhados três gêneros por unidade, um oral, um escrito (comum ao dia a dia dos estudantes) e um literário, que serviriam de aporte para o trabalho com os eixos de ensino, totalizando doze gêneros de texto por ano e quarenta e oito no decorrer dessa etapa de escolaridade, sem descartar, é claro, outros gêneros que poderiam ser trabalhados de forma periférica. A título de exemplo, podemos citar o gênero seminário que ao ser ensinado pode demandar o trato com os gêneros cartaz, gráfico, resumo etc. Interessa saber, ainda, que, atualmente, o Currículo de Português do Estado de Pernambuco sugere setenta e seis diferentes gêneros de textos para serem abordados no Ensino Fundamental II, sem contar com os "suportes textuais", capacidades da linguagem (Dolz, Noverraz e Schneuwly, 2004) ou recursos muito gerais, que impossibilitam a classificação específica de gênero. Levando em consideração questões quantitativas, acreditamos que, seguindo o modelo apresentado, a possibilidade de se trabalhar os gêneros de forma mais aprofundada nessa etapa de escolaridade seria significativamente mais concreta pelo fato de haver uma redução de vinte e oito indicações de gêneros para o trabalho pedagógico.

A estrutura da Figura 3, portanto, apresenta sete fases na qual denominamos: (1) apresentação do gênero textual, essa fase consiste na definição pelo professor do gênero a ser trabalhado; (2) leitura ou escuta, envolve diferentes maneiras de leitura/escuta de textos prontos do gênero adotado, desde atividades individuais até as compartilhadas reflexivas para discussão de características particulares do gênero, estrutura, conteúdo etc.; (3) análise linguística do gênero, utiliza estratégias didáticas para o trato com a ortografia, sintática, semântica, pragmática etc.; (4) apresentação da situação, na qual o professor exibirá ao estudante uma situação de comunicação visando à produção textual oral ou escrita que, na fase 6, chegará a sua versão final e real; (5) produção de texto inicial, ocorre somente após o estudante já ter se apropriado acerca do gênero abordado na aula; (6) revisão reflexiva, sendo ancorada nos textos produzidos, essa fase busca a identificação das dúvidas e dificuldades dos estudantes por meio de discussão coletiva impessoal a respeito das produções, e, simultaneamente, retomando conceitos e conteúdos trabalhados envolvendo o gênero em questão; e, por fim, (7) produção final, nesse momento, a produção deve ser verídica, possibilitando, dessa forma, a efetiva participação dos estudantes em situações reais nas mais diversas esferas comunicativas, como no meio acadêmico - com a produção de artigos, projetos, entre outros - no meio jornalístico - oportunizando a elaboração de notícias, reportagens para a divulgação em periódico ou rádio da escola, por exemplo - no meio profissional mediante a construção de currículo etc.

Conseguir fazer o estudante agir, interagir, analisar, refletir, refazer quando necessário é essencial no processo de ensino-aprendizagem. Assim, por meio da intervenção do professor, o estudante se apropriará de estratégias metacognitivas paulatinamente. Segundo Portilho (2009, p. 151), ninguém nasce tendo conhecimento e controle metacognitivos suficientes, havendo, portanto, a necessidade de ensinálos. 0 autor apresenta, ainda, por meio do esquema a seguir, etapas que, segundo ele, devem ser consideradas pelo professor para o desenvolvimento de um ensino metacognitivo.

Figura 4 - Ensino metacognitivo

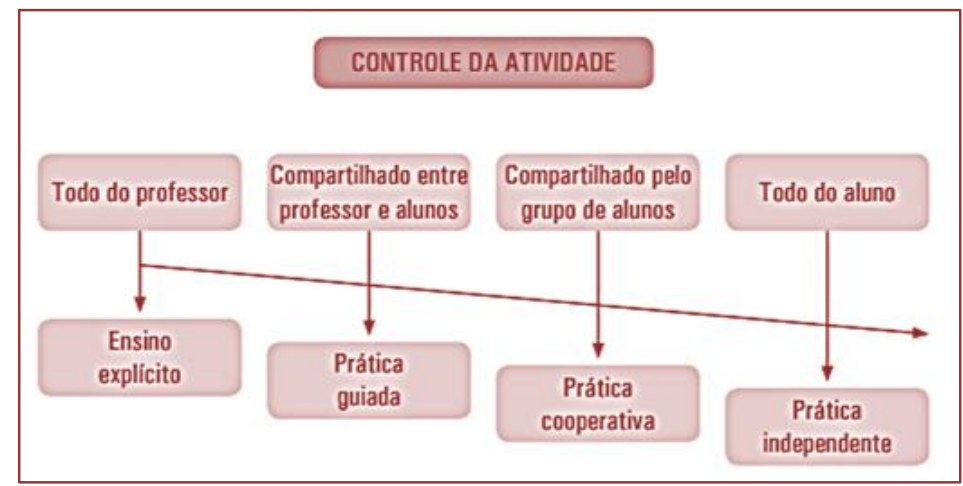

Fonte: Portilho (2009, p. 152) 
Ao relacionarmos a estruturação de sequências didáticas (Figura 3) ao ensino metacognitivo (Figura 4), podemos segmentar as ações da seguinte maneira: as fases 1 e 4 (apresentação do gênero textual e apresentação da situação, respectivamente) correspondem ao ensino explícito, de responsabilidade apenas do professor. Nessas situações, o estudante participará somente como espectador, pois cabe ao professor a definição do gênero norteador das atividades, contexto de produção e outros aspectos necessários a sua compreensão e produção.

As fases 2, 3 e 6 (leitura ou escuta, análise linguística do gênero e revisão reflexiva), por sua vez, são vivenciadas por meio das práticas guiada e cooperativa, tendo em vista que o ensino acontece por meio do compartilhamento de ideias entre os estudantes, com a intervenção constante do professor, mediante análises, reflexões e discussões acerca dos textos lidos/ouvidos ou produzidos, resultando no desenvolvimento de processos cognitivos, possibilitando o aperfeiçoamento e a ampliação de competências individuais.

Por fim, a prática independente fica por conta das fases 5 e 7 (produção de texto inicial e produção final), nas quais os estudantes devem usar de sua autonomia para a elaboração do gênero trabalhado. Vale salientar que essa produção pode ser coletiva, em dupla, trio ou em equipe, por exemplo, mas, mesmo assim, exigirá do estudante habilidades individuais de construção e organização do pensamento, resultando em sua composição de fato.

\section{CONCLUSÕES}

Diante disso, é possível observar como o ensino de Língua Portuguesa precisa estar voltado para a formação de estudantes reflexivos, capazes de ser responsáveis por sua própria aprendizagem. Para isso, é necessário a adoção de situações didáticas que favoreçam o desenvolvimento de habilidades metacognitivas a partir do trabalho com os gêneros textuais, pois, dessa forma, haverá a possibilidade da vivência de um processo de ensino-aprendizagem pautado em ações situadas e semelhantes ao máximo da realidade social dos discentes e docentes.

Nesse sentido, entendemos que as competências para a compreensão e produção textual, em muitos casos, se dá automaticamente, pois a língua somente ocorre sob a forma de textos, mas, a escola é a instituição responsável pelo ensino de competências pertencentes a situações mais complexas de comunicação, que, por sua vez, também é responsável pela formação de seres pensantes, autocríticos e autônomos na monitorização e regulação de suas próprias atividades cognitivas.

Sendo assim, acreditamos que o ensino da língua materna teria melhores resultados se fosse norteado por um modelo didático educacional que adotasse os gêneros textuais como eixo principal do processo de ensino-aprendizagem e a metacognição como atividade constante no dia a dia da escola, conduzindo a práticas pedagógicas mais significativas, reflexivas e consequentemente mais eficazes.

\section{REFERÊNCIAS}

[1] ANTUNES, Irandé. 2009. Língua, texto e ensino: outra escola possível. São Paulo: Parábola Editorial.

[2] BAKHTIN. M. Estética da Criação Verbal. Tradução de Maria E. Galvão e revisão de Marina Appenzeller. 3. ed. São Paulo: Martins Fontes, 2000.

[3] BRASIL. Constituição (1988). Constituição da República Federativa do Brasil. Brasília, DF: Senado Federal: Centro Gráfico, 1988.

[4] BRASIL. Lei de Diretrizes e Bases da Educação (LDB), no 5.692 de 11 de agosto 1971. Brasília: MEC, 1971.

[5] BRASIL. Lei de Diretrizes e Bases da Educação (LDB), no 9.394 de 20 de dezembro 1996. Brasília: MEC, 1996.

[6] BRASIL. Parâmetros Curriculares Nacionais (PCN). Língua Portuguesa. Ensino Fundamental. Terceiro e quarto ciclos. Brasília: MEC/SEF, 1998.

[7] BRASIL. Ministério da Educação (MEC). Parâmetros Curriculares Nacionais do Ensino Médio (PCNEM). Dispõem sobre orientações e parâmetros para o Ensino Médio. Documento disponível em http://portal.mec.gov.br/setec/arquivos/pdf/BasesLegais.pdf. Acessado em 27 de fevereiro de 2017.

[8] BRONCKART, Jean-Paul. Atividade de linguagem, discurso e desenvolvimento humano. Por um interacionismo sociodiscursivo. Trad. Anna Rachel Machado e Péricles Cunha. São Paulo: Edusc, 1999/2006 [1997].

[9] FLAVELL, J. H. (1976). Metacognitive Aspects of Problem Solving. In L. B. Resnick (Ed), The nature of intelligence. Hillsdale, NF: Erlbaum. 1976, pp. 231-236. 
[10] Instituto Nacional de Estudos e Pesquisas Educacionais Anísio Teixeira. Ministério da Educação INEP [on line]. Ministério da $\quad$ Educação. Disponível http://smeduquedecaxias.rj.gov.br/nead/Biblioteca/Gest\%C3\%A3o/IDEB/portal.inep.gov.br/web/saeb-e-provabrasil/perguntas-frequentes.html. Acessado em janeiro de 2017.

[11] MAGALHÃES, A. F. Lateralidade: implicações no desenvolvimento infantil. Rio de Janeiro: Sprint, 2001.

[12] PFROMM NETO, Samuel; DIB, Cláudio Zaki; ROSAMILHA, Nelson. O livro na educação. Rio de Janeiro, RJ: Primor/INL, 1974.

[13] PORTILHO, Evelise M. Labatut. Como se aprende? Estratégias, estilos e metacognição. Rio de Janeiro: Wak, 2009.

[14] RAZZINI, Marcia P. G. "História da Disciplina Português na Escola Secundária Brasileira”. Revista Tempos e Espaços em Educação. Universidade Federal de Sergipe, Núcleo de Pós-Graduação em Educação. v. 4, jan./jun. 2010, p. 43-58. ISSN: 1983-6597.

[15] RIBEIRO. Célia. Metacognição: Um Apoio ao Processo de Aprendizagem. Psicologia: Reflexão e Crítica. 2003, 16 (1), pp. 109-116.

[16] SCHNEUWLY, B. e DOLZ, J. Gêneros orais e escritos na escola. São Paulo: Mercado de Letras, 2004.

[17] SOARES, Magda. Português na escola: história de uma disciplina curricular. In: BAGNO, Marcos (Org.). Linguística da norma. São Paulo: Loyola, 2002.

[18] TRAVAGLIA, L. C. Gramática e interação: uma proposta para o ensino de gramática no $1^{\circ}$ e $2^{\circ}$ graus. 4 . ed. São Paulo: Cortez, 1998. 


\section{Capítulo 13}

\section{Valorizando a leitura como prática educativa dentro e fora da escola}

\section{Isabel Marth de Souza \\ Lauraci Dondé da Silva}

Resumo: 0 presente estudo teórico buscou compreender os caminhos existentes entre as práticas de leitura, dentro e fora do espaço escolar, a partir do olhar de docentes e discentes. A prática da leitura é uma tarefa essencial para a construção de conhecimento, fazendo-se necessária desde a primeira infância, nesta fase através de imagens, valorizando o letramento como prática social interativa. Deste modo surge a importância de enfatizar este tema com os futuros educadores do Curso Técnico de Magistério como ocorreu neste estudo - para que os docentes possam contribuir para o processo evolutivo das crianças, com práticas pedagógicas que perpassem as salas de aula e chegassem até as famílias dos educandos.

Palavras Chave: Leitura, letramento, interação, escola, família. 


\section{INTRODUÇÃO}

O trabalho de pesquisa "Valorizando a leitura como prática educativa dentro e fora da escola" tem o objetivo de enfatizar esse tema com os professores e alunos, para que possam ter um olhar diferente frente à criança e sua aprendizagem, incentivando os pais e todas as comunidades escolares a romper paradigmas e realizar práticas de leitura em inúmeros espaços. A falta de tempo de muitos pais, devido à correria de seus afazeres diários reflete em ausências nas crianças. A carência de afeto é fato marcante em nossos alunos em sala de aula. Os professores exercem um papel de muita influência, seus ensinamentos e trocas de saberes perpassam as paredes da escola e vão até as famílias dos educandos, por isso é preciso ter consciência da importância de seu papel como educadores. Compreendendo que o processo educativo depende do professor para promover uma aprendizagem de qualidade é que se faz de extrema importância um trabalho de gestão e formação docente com os professores e futuros educadores, pois através deles é que mobilizaremos as escolas para cumprirem seus papéis de educar para a vida. 0 aporte teórico foi construído com base nas argumentações de Alçada (1990), Dinorah (1995), Solé (1998), Ziberman (2003), entre outros. Estes autores fundamentam a necessidade de práticas de leitura de qualidade dentro e fora das escolas, discorrendo sobre a necessidade urgente de pensar a educação do presente assumindo um papel social em relação às problemáticas atuais que existem em todas as instituições de ensino.

\section{CONTEXTUALIZAÇÃO E JUSTIFICATIVA}

A prática da leitura constitui-se um pilar para a construção do conhecimento, sendo instrumento fundamental desde a primeira infância. Deste modo é imprescindível trabalhar essa temática com os futuros docentes do curso magistério, para a partir de um planejamento adequado possam estar incentivando os pais de seus alunos a contar histórias para seus filhos.

Segundo Dinorah (1995, p.49):

Se os pais tivessem consciência da importância de contar uma história ao pé da cama para seus pequenos, certamente teríamos uma adolescência menos traumatizada. A voz do pai ou da mãe passando pros meninos os componentes mágicos - algo tão inerente a sua própria infância - supreas de uma afetividade diária nem sempre possível na realidade brasileira, e que irá minimizar os conflitos ocasionados em seu crescimento, por falta dessa mesma afetividade.

A correia da vida atual reflete em falta de tempo para muitos pais no convívio com seus filhos. A família, como a primeira instituição tem esse papel inicial de incentivar práticas de leitura em casa. Nesse contexto, Dinorah (1995) aponta o ato de contar histórias para além da mágica viagem da literatura que se faz em um livro, mas uma possibilidade de demonstrar afeto ao narrar esses fatos ao pé do ouvido para seus filhos.

Os docentes propiciam a troca de saberes através das interações que proporcionam em sala de aula, esse espaço de aprendizagem coletiva precisa de planejamento adequado para comtemplar cada etapa do desenvolvimento das crianças. Os alunos do curso de magistério precisam ter consciência da importância de seu papel como educadores. De acordo com Lück (2010, p.30):

Cabe lembrar que toda pessoa tem um papel de influência sobre o contexto de que faz parte, exercendo-o, independentemente de sua consciência desse fato e da direção e intenção de sua atividade.

Em sala de aula, quando há um trabalho voltado para o incentivo à leitura, os educandos fazem naturalmente esse papel de pedir a seus pais :“Conta uma história pra mim por favor?" Por isso a necessidade de abranger esse assunto na escola, pois a partir dessa parceria entre escola e família, a aprendizagem das crianças torna-se significativa, apresentando resultados satisfatórios, pois é possível mediar o processo evolutivo da criança com planejamento que respeita as especificidades dela.

Os docentes auxiliam diretamente nas aprendizagens dos educandos, sendo mediadores do processo educativo dentro do espaço escolar. A leitura é uma prática que precisa ser ensinada, dentre os inúmeros aprendizados que a escola incentiva, este é fundamental. Para auxiliar neste incentivo, é importante um trabalho de gestão e formação docente com os professores e futuros educadores, visto que a partir de sua prática pedagógica é possível mobilizar as escolas para cumprirem seus papéis de educar de forma integral.Luck(2005, p.15)destaca que: 
Em síntese, a eficácia do processo educativo centra-se no professor: seus conhecimentos, suas habilidades e suas atitudes em relação ao aluno a quem deve motivar. Torna-se, pois, de vital importância promover, antes de mais nada, o desenvolvimento desse professor, orientá-lo e assisti-lo na promoção de um ambiente escolar e processo educativo significativos para o educando.

Percebo atualmente que na era digital que vivemos, o uso do livro físico é cada vez menor, com este projeto venho resgatar o uso dele, bem como proporcionar propostas que valorizem a prática da leitura dentro do espaço escolar, fazendo um trabalho que se estenda até as famílias dos educandos.

Nossas bibliotecas já não tem a mesma procura de tempos atrás, não podemos deixar as histórias morrerem esquecidas nas prateleiras, os livros pegando poeira, guardados em armários. Os livros precisam circular, através desse contato com eles é que as histórias ganham vida nas mãos dos leitores.

0 educador precisa estar atento as necessidades de sua escola, ter um olhar para cada criança sendo observador de sua realidade e das peculiaridades da mesma.

O educador em sala de aula também precisa ser empreendedor. Empreender no sentido de conhecer seus educandos para poder entendê-los, para identificar e buscar respostas às suas demandas. Ser empreendedor leva a comportamentos e atitudes, tais como: capacidade de sonhar, perseverança, criatividade, flexibilidade e proatividade(FERNANDES, 2010, p.64).

A leitura é um ato que, também, depende de estímulo e motivação, por isso é tão importante esse trabalho com os alunos de magistério, pois essa prática é uma tarefa essencial para a construção do conhecimento, constituindo-se um dispositivo para auxiliar no pensamento crítico do indivíduo, contribuindo para o prazer pessoal e ampliando os interesses do mesmo.

Diante de todos esses benefícios da leitura, justifico meu trabalho com imenso prazer de me propor incentivar essas práticas na escola onde eu me formei professora no ao de 2010, o Instituto Estadual de Educação Princesa Isabel em Cachoeirinha. Portanto, se hoje tenho esse desejo de ensinar, preciso destacar que esta semente foi plantada primeiramente nesta escola.

\section{PRÁTICAS DE LEITURA NO CENÁRIO ATUAL}

Atualmente os índices de leitura têm caído gradativamente entre a população, estamos lendo menos e este é um fator marcante em nossa aprendizagem, pois quem lê menos apresenta dificuldade de memorizar com maior qualidade, diante dessa realidade é imprescindível práticas pedagógicas de incentivo à leitura dentro e fora da escola. ALLIENDE (2005, p. 2) faz reflete:

Alguns pensam que no futuro, e inclusive hoje em dia, a leitura poderia ser substituída vantajosamente pela imagem, pela palavra gravada e pelo acúmulo mecânico da informação. Essa opinião surge da comprovação empírica de que em muitos países numerosas pessoas podem se sair muito bem em diversas atividades sem apelar em nada para a leitura.

Pretendo mostrar com as ações desse projeto que a leitura é indispensável para o conhecimento humano e insubstituível, todos os avanços que temos servem para agregar, para contribuir, mas não suprem a falta que faz o ato de ler na aprendizagem. Compreendo que aprendemos a ler o mundo e a leitura vai muito além de decifrar o código escrito, mas não sou favorável a ideia de buscar meios para substituir essa tão importante competência a ser desenvolvida, pois seria um retrocesso pensar assim.

A escola exerce um papel fundamental para auxiliar no prazer pela leitura desde cedo, pois promove o hábito nas crianças e estas irão crescer sabendo que a leitura enriquece o conhecimento por elas adquirido. Por outro lado, quem mais incentiva estes hábitos na escola são os professores, logo, para que tenhamos alunos que gostem de ler, precisamos de professores leitores e que tenham essa paixão pelos livros. Surge ai a necessidade de aplicar este projeto em uma escola que tenha o Curso Normal Magistério, o qual habilita professores para lecionar desde a educação infantil até o 5o ano do ensino fundamental. Esses professores deverão ter esse desejo de ensinar e mostrar para os educandos o prazer por trás de ler um livro. 
Sabemos que há muito, mas muito mesmo, por fazer, neste país de poucas letras e excessiva omissão. Mas sabemos também que não basta a técnica para fazer o país do futuro. É necessário e urgente que a cultura com base na leitura - tenha vez, para que as mentes saiam da letargia avassaladora do progresso desumano e comecem a formar o mundo melhor e maior (DINORAH, 1995, p.9).

Vivemos em uma era que tudo é instantâneo, rápido demais, é necessário desacelerar um pouco, a leitura precisa ser um hábito ensinado com prazer, os professores devem se empenhar para plantar essa semente em seus alunos. A partir do trabalho do educador em sala de aula, toda a comunidade escolar passa a ganhar, pois as crianças vão para casa e contam sobre as histórias que ouviram, esse reconto literário é riquíssimo e promove mudanças nos hábitos das famílias.

Outro ponto de destaque na escola é a oralidade, a linguagem é um dos principais meios pelo qual a aprendizagem se dá. A leitura e a escrita depende diretamente e indiretamente da oralidade, pois a própria fala como todos sabem se dá por imitação da fala do adulto.

Machado(2003, p.61)explica que:

Através da linguagem, de importância vital reconhecida para a vida humana, torna-se possível a comunicação dos princípios de ordem geral entre os semelhantes, em sua dupla dimensão - compreensão e interpretação da linguagem alheia e interpretação e expressão da própria linguagem. A comunicação por meio da linguagem permite ao homem viver em sociedade, por que esta é a forma de traduzir os pensamentos de cada um.

Na África, a arte de contar histórias é levada a sério, os Griôs que são contadores de histórias e fazem parte da tradição oral Africana, utilizada para designar mestres portadores de saberes e fazeres da cultura local. Eles passam de geração para geração a arte de contar suas vivências relatando fatos que aconteceram com eles. As crianças Africanas aprendem com seus pais e avós essa tarefa que levam para a vida toda de forma muito significativa.

Assim como os Griôs, nós educadores devemos ter o hábito de contar histórias aos nossos alunos, pois a escola tem que ter espaço para a literatura sempre. Conforme Dinorah (1995, p.55-56):

A história aquieta, asserena, prende a atenção, informa, socializa, educa. Quanto menor for a intenção de alcançar tais objetivos, maior sua influência. A história é alimento da imaginação, favorecendo a aceitação de situações desagradáveis, ajudando a resolver conflitos, acenando com a esperança.

Assim, as histórias devem fazer parte do planejamento diário dos educadores como um recurso para auxiliar na aprendizagem dos alunos, para que possamos deste modo prepará-los para esse mundo moderno e contemporâneo. Uma sociedade letrada precisa saber ler e escrever, compreendendo o que lê, vai muito além de uma leitura mecanizada, é indispensável uma leitura significativa. Pode-se dizer que é através da leitura que o indivíduo cria o gosto pela formação de textos, escrevendo e melhorando sua escrita a cada nova leitura que ele faz.

Observo a dificuldade que muitos leitores têm de ler uma obra completa, reflexo da era atual onde tudo é muito instantâneo, este fato vem até a escola e traz para os educadores mais este desafio, ou seja, fazer com que os estudantes descubram o modo prazeroso de ler. Segundo Zilberman (2003, p. 21):

Note-se que o leitor é qualificado de indivíduo perspicaz e apto para sofrer uma narrativa de princípio ao fim. Com isso, parece estabelecer-se um tipo de familiaridade, que vai além daquela existente entre quem conta uma história e um ouvinte que se deseja atento.

Deste modo é indispensável estratégias diárias de incentivo a leitura dentro do espaço escolar, os educandos precisam compreender que o ato de ler é não deve ser instantâneo, ou seja uma leitura corrida sem a mínima compreensão. É preciso ler de modo distante da instantaneidade do mundo atual, ler com emoção e desejo de aprender com cada novo livro e esse amor deve ser ensinado em sala de aula pelos educadores. 


\subsection{VALORIZAÇÃO DO ESPAÇO DA BIBLIOTECA}

As escolas empenham-se em organizar tempos e espaços para propiciar práticas de letramento e leitura na escola, as bibliotecas escolares foram criadas para suprir essa necessidade. De acordo com Solé(1998, p.34):

Atualmente, na escola e ao longo da etapa fundamental, dedicam-se várias horas por semana à linguagem, em que se situa uma parte importante do trabalho de leitura (em geral costuma-se prever um horário de biblioteca nas escolas, tanto na sala de aula como nos aposentos destinados a este objetivo.

O espaço da biblioteca escolar deve ser valorizado nas escolas como meio de incentivo à leitura, esse local é riquíssimo e precisa ser mostrado aos alunos. Fazer visitas guiadas, levando os educandos para que conheçam diferentes obras de escritores é muito importante, essas trocas de saberes entre eles proporcionam aprendizagens e auxiliam despertando o desejo por conhecer diferentes títulos literários e não literários.

As escolas geralmente dispõem de bibliotecas para uso de toda a comunidade escolar, embora com a existência desses espaços garantidos, me preocupo com a gestão dos mesmos e o modo como são utilizados, pois por vezes eles infelizmente se tornam depósitos de livros sem ser feito um trabalho para aproximar os educandos e valorizar as práticas de letramento. As bibliotecas surgiram com o intuito de um espaço para que se possa conhecer obras literárias e descobrir o desejo de ler, mas não é o que acontece na maioria das vezes. Almeida (2003, p.51) explica:

A biblioteca pública nasce em meados do século XIX, com base na necessidade de mão-de-obra especializada e da exigência da sociedade por acesso à educação pública. Na verdade, esse tipo de biblioteca não é uma reivindicação específica da sociedade, mas encontra-se no bojo de uma reivindicação maior, ou seja, como dissemos, o acesso da população ao ensino público.

Por isso, a necessidade de revitalizar esses espaços que foram criados há tempos atrás para garantir o acesso da população aos livros. Percebo que há uma pequena parcela da sociedade que consegue adquirir livros para seu uso, essas compras não são prioridade principalmente para as famílias que possuem menor poder aquisitivo.

\subsection{A LEITURA E A COMUNIDADE ESCOLAR}

A escola deve aproximar a comunidade escolar dessas práticas através de ações que visem o compartilhamento de saberes, pois é um espaço de socialização que se constitui um laboratório de aprendizagem. Segundo Alçada (1990, p.18):

A escola é o local privilegiado de contato com os livros. Só recentemente se designou à escola o objetivo de criar leitores, utilizando processos de trabalho adequados e incluindo nos programas de Português, nos vários níveis de escolaridade, a leitura da obra completa.

Criar leitores é uma tarefa que exige comprometimento não apenas dos professores, mas de todos os segmentos da escola, pois a leitura perpassa as paredes das salas de aula e as divisões entre as disciplinas metodológicas. A literatura deve ser entendida como arte, para isso há necessidade de um cuidado quando buscamos a contação de uma história apenas para explicar ou dar introdução a um conteúdo. A história deve ser contada não apenas para cumprir conteúdos escolares, mas pelo prazer de conhecer uma obra literária sabendo apreciá-la e tirar o melhor dela.

Para Rodrigues (2005, p.4):

A contação de histórias é atividade própria de incentivo à imaginação e o trânsito entre o fictício e o real. Ao preparar uma história para ser contada tomamos a experiência do narrador e de cada personagem como nossa e ampliamos nossa experiência vivencial por meio da narrativa do autor. Os fatos, as cenas e os contextos são do plano imaginário, mas os sentimentos e as emoções transcendem a ficção e se materializam na vida real. 
Assim, a contação de histórias é uma atividade muito importante na escola, que transmite conhecimentos e valores, sendo sua atuação muito decisiva no desenvolvimento do processo de ensino aprendizagem dos educandos e na formação integral deles enquanto sujeitos sociais.

Nós educadores precisamos estar sempre aprendendo para lidar com as situações que acontecem em sala de aula, fazendo ações que melhorem cada vez mais nosso fazer pedagógico dentro da escola, pois é indispensável que façamos esforços para garantir uma educação de qualidade, formando leitores conscientes de seu papel perante a sociedade.

Luckesi (1994, p.116) salienta que:

A ação do educador não poderá ser executada de qualquer forma, como se toda e qualquer forma fosse suficiente para que ela possa ser bem realizada. Ela só poderá ser bem realizada se tiver um compromisso político que a direcione.

Ou seja, apenas a prática docente não é suficiente para o desenvolvimento de um trabalho pedagógico eficaz em sala de aula, o ato de ensinar é complexo e exige exímio trabalho dos educadores, é preciso buscar conhecimento específico e colocá-lo em prática.

Esse é nosso papel enquanto educadores, despertar o desejo de valorizar a leitura como meio significativo de aprendizagem, melhorando a qualidade do ensino para nossas crianças, formando cidadãos, com senso crítico e capazes de serem agentes transformadores da realidade na qual vivem.

\section{METODOLOGIA}

O método utilizado para a pesquisa foi uma abordagem qualitativa, buscando trazer ao leitor aparatos para a compreensão e questionamento dos temas abordados. Foram realizadas diversas pesquisas sobre as práticas de leitura utilizadas atualmente nas instituições, por meio de leituras das obras de autores que defendem o incentivo à leitura. Foi realizada observação em uma turma de futuros educadores, alunos do curso de magistério do município de Cachoeirinha-RS, assim como uma intervenção docente, para a qual foi planejado um projeto que abrangeu toda a comunidade escolar local.

\section{RESULTADOS E DISCUSSÃO}

A proposta de trabalho surgiu através da necessidade da escola. No início das observações percebi que havia uma biblioteca grande na escola, mas não existia um trabalho de incentivo a visitarem esse espaço da escola e o valorizarem como espaço de aprendizagem. Visitei as salas de aulas das duas turmas de primeiro ano, onde foi aplicado o Projeto de Intervenção, acompanhando as rotinas escolares delas por uma semana. Observei todo o processo de ação da equipe docente e dos gestores da escola, os métodos que utilizavam para fazer as propostas pedagógicas.

Depois das observações teve um tempo de afastamento para o desenvolvimento do meu projeto. Após a montagem e organização deste iniciei a prática de gestão.

No primeiro dia da minha organização para o desenvolvimento da intervenção, que constituiu-se o primeiro encontro, encontrei nas dependências da escola, a coordenadora do curso Maria Alice e uma educadora das turmas, a Cristiane, que leciona aulas de Literatura para os futuros professores. A relevância da presença desta educadora se dá justamente por ela ser uma professora que faz esforços para valorizar práticas literárias dentro da escola. Mostrei o projeto a elas e juntas fizemos alguns pequenos ajustes referentes aos horários de aplicação. Ambas gostaram muito das propostas e não fizeram alterações na parte pedagógica dele, apenas nos horários. Deixamos acordado que na próxima quintafeira, dia 19/04, eu entraria nas duas turmas para explicar as propostas que iríamos desenvolver juntas.

O segundo encontro iniciei na turma 107, apresentando o tema do projeto Valorizando a leitura como prática educativa dentro e fora da escola, fizemos uma breve discussão sobre os principais pontos do mesmo, onde percebi que os alunos mostraram-se participativos, expondo suas opiniões. Após, propus na turma a discussão sobre a importância do ato de ler com slides explicativos e os índices de leitura no Brasil e no mundo. Muitos dados mostrados deixaram os educandos surpresos, eles mostraram-se muito participativos, interagindo e contando como são os hábitos de leituras deles. A maioria da turma gosta de ler e tem esse hábito, já uma minoria explicou que lê apenas os livros exigidos para a disciplina do curso que estão fazendo. Há também na turma muitas mulheres que são mães, e relataram que costumam ler 
para seus filhos diferentes livros. Aproveitei a oportunidade para reforçar a importância delas incentivarem a leitura de modo prazeroso em seus filhos.

Levei a turma até a biblioteca da escola, fizemos uma visita ao espaço observando o local e quão rica ela é de cultura para a escola. Solicitei que observassem primeiro com olhos de educadores pensando em como explorar da melhor maneira aquele espaço e depois com olhos de crianças, como as crianças iriam ver esse espaço. Retornamos para a sala de aula com muitas ideias e os pensamentos borbulhando para fazer os cartazes, esse era meu intuito com a visita na escola. Solicitei que a turma se dividisse em grupos e que elaborassem um cartaz incentivando toda a comunidade escolar a ir visitar a biblioteca da escola e escolher livros para fazer suas leituras.

Ressaltei com eles que alguns professores infelizmente não possuem o hábito de ler nem mesmo para si, e é muito difícil ensinar sobre algo que nós mesmos não gostamos, por isso é tão importante plantar essa semente do prazer de ler nos educadores, além disso, o professor deve planejar, sempre inovar suas aulas tornando-as mais significativas. De acordo com BRASIL:

Para a boa utilização do livro de leitura, é necessário estabelecer um esquema básico de aula de leitura. Sobre esta base, o professor vai planejar e desenvolver as atividades, considerando as necessidades da turma, as condições materiais da classe e a disponibilidade de tempo, despertando no aluno o interesse de aprender(MEC,1970, p.35).

Eles produziram cartazes lindos mostrando-se muito dedicados e criativos em suas produções, após terminarem levaram os cartazes e colaram nos corredores da escola para que as outras turmas se sentissem incentivadas a ir até a biblioteca conhecer o espaço.

0 segundo encontro na turma 108 ocorreu no mesmo dia e não foi diferente da turma anterior, me surpreendi com a participação da turma nas propostas trazidas. Em nosso debate com os dados nacionais e mundiais de leitura, muitos educandos mostraram seus saberes expondo o que entendiam do assunto. Percebi que houve um interesse da turma em pesquisar sobre o tema de nosso projeto antes de nosso primeiro encontro. Esse interesse deles foi muito importante para nossas propostas serem bem-sucedidas. Durante a ida na biblioteca mostraram-se observadores, olhando o espaço ao seu redor com atenção pensando em como melhorar aquele ambiente literário da escola. Organizaram os cartazes de incentivo à leitura com muita criatividade com materiais coloridos que os deixaram muito bem apresentáveis, muitos alunos levaram personagens em E.V.A para enfeitar suas produções.

No nosso terceiro encontro a proposta principal era a confecção da sacola literária e do caderno de registros para o projeto da sacola. Na turma 107 eles se dividiram em grupos de acordo com suas afinidades e iniciaram entusiasmados a confecção das sacolas. Fiz uma fala inicial para a turma ressaltando a importância a confecção desse recurso pedagógico para auxiliar na prática docente deles. Trabalharam de forma cooperativa auxiliando uns os outros desde a escolha dos materiais até a montagem final do recurso. Ao montarmos o caderno, deram sugestões do que escrever na página inicial explicativa para as famílias que receberem o caderno, a partir de suas ideias montamos de forma coletiva o texto.

Na turma 108, a proposta para o encontro foi também a confecção da Sacola Literária percebi que alguns alunos de adiantaram e trouxeram suas sacolas com algumas decorações prontas, essa atitude foi boa para os colegas, pois quem já estava com sua sacola mais encaminhada pode oferecer ajuda aos seus colegas auxiliando-os na montagem. Referente a elaboração dos cadernos de registros mostraram-se muito solícitos e participativos, pensaram em grupos na melhor maneira de montar o texto inicial do caderno e assim o fizeram. Ao encapar e enfeitar seus cadernos pensaram em seu dia a dia de práticas nas escolas e como seria melhor esse recurso.

Nosso quarto encontro tinha o objetivo de mostrar para os futuros professores a importância da Hora do Conto na sala de aula, foi apresentado para as turmas o Avental pedagógico para a contação de histórias e como ele é o modo correto de usá-lo como recurso pedagógico, na turma 107 alguns já o conheciam e na turma 108, o interesse por saber como explorar da melhor maneira tal recurso foi grande. Ressaltei a eles a necessidade de manter vivo o ato de contar histórias como na África onde os Grios mantém viva a cultura de contar fatos através do conto e reconto dos mesmos.

No segundo momento trouxe para as turmas material impresso para a discussão sobre o assunto e a importância do livro físico, visto que na era atual em que vivemos e percebo que estamos perdendo cada vez mais o contato com ele, impresso, pois os hábitos de leitura hoje migraram do tradicional para a leitura virtual, a qual é interessante também, o ato de ler é o mesmo, mas a valorização da obra impressa é 
um caminho que precisamos fazer para que não haja a falência da cultura escrita. Ambas as turmas, participaram ativamente da discussão promovida na sala expondo suas opiniões de forma objetiva e clara.

Proporcionei para ambos os grupos, a oportunidade de ouvir uma história, contei a eles: Batidas de Okan, da autora Rosane Castro, esse livro narra a trajetória de uma família Africana e o modo como elas valorizam a cultura de contar fatos que ocorreram com eles.

Segundo Solé (1998, p.33):

Gostaria de acrescentar também que, quando a discussão centra-se nos métodos, ou nas idades em que se deve ser iniciada a instrução formal, opera-se simultaneamente uma assimilação e uma restrição: assimila-se a aquisição e o ensino da leitura à aquisição e o ensino do código e se restringe aquilo que a leitura envolve e que supera as habilidades de decodificação.

Ou seja, os educadores precisam ampliar seu olhar sobre o ato de ler, pois ele vai muito além da decodificação do código escrito, precisa ser prazeroso e significativo para o sujeito aprendente, a partir dessas ideias é que planejamos as ações para a comunidade escolar visando práticas de leitura que perpassassem as paredes das salas de aulas e chegassem até as famílias.

No próximo encontro disponibilizei para os educandos diferentes recursos para contação de histórias, como Caixa de Fantoches, Caixa de Objetos Indígenas, com estes em mãos, eu solicitei que eles se dividissem em grupos e contassem uma história para seus colegas. Os grupos fizeram apresentações muito criativas usando os fantoches.

Na última quinta-feira de nossos encontros fizemos um Piquenique Literário para toda a escola, neste da ambas as turmas trabalharam juntas na montagem e organização do mesmo. Colocaram os tapetes no pátio da escola, eles se preocuparam em montar em um lugar que fosse coberto por telhado próximo ao bar da escola. Esse espaço foi escolhido estrategicamente por ser um local de movimentação de alunos e professores no horário de intervalo das turmas, ou seja, de fácil acesso a todos para participarem do piquenique. No horário de intervalo a proposta superou as nossas expectativas, visto que houve muita procura por livros no espaço que montamos. Os alunos e professores participaram com entusiasmo do troca-troca, trouxeram livros para doar e pegaram os que lhes chamavam a atenção. Ao término da proposta sobraram poucos livros.

O piquenique foi tão gratificante que as duas turmas de magistério pediram para repetirmos ele no sábado que faremos 0 Sarau Literário, deste modo eles irão organizar novamente para a comunidade escolar, agora em um espaço mais amplo e que contemple mais pessoas, visto que no sábado haverá circulação de pais, alunos e professores dentro da escola para participar de diversas atividades abertas à comunidade.

A partir de uma necessidade de ambas as turmas e um pedido da professora titular delas, solicitei que elaborassem um relatório sobre o projeto, destacando os pontos mais importantes de cada etapa, que será entregue um relatório por turma, no qual deve haver a participação de todos os futuros professores envolvidos na proposta, cada um escolherá um item do projeto e deverá relatar como foi desde sua participação nele até quais aprendizagens teve e como o mesmo contribuiu para sua carreira docente.

A organização das turmas na execução das tarefas foi indispensável para que as propostas fossem bem aplicadas, planejar um sarau para a comunidade na culminância do projeto exigiu um verdadeiro trabalho em equipe, conforme Ferreira:

A capacidade de organização é que vai garantir a equilibridade do que foi coletivamente planejado e revelar a competência dos profissionais da educação. É ai que se revelam os compromissos democráticos de todos os responsáveis pelo processo educacional, na garantia de fazer acontecer a todos os educandos (2009, P. 70).

Nossa culminância foi em um sábado letivo. Com minha orientação, as turmas 107 e 108 fizeram um sarau para toda a comunidade escolar elaborando e montando o mesmo. Elas trabalharam juntas na construção desse espaço que foi aberto a todos e beneficiou muito as pessoas dessa localidade. Para organização do local, os futuros professores solicitaram para a direção uma sala de aula, onde trocaram a disposição das mesas e montaram 4 cantos de interação com a comunidade, sendo, primeiro o cantinho da hora do conto, onde eles montaram um teatro para fantoches, e neste espaço educadores ficaram se revezando para contar histórias para as crianças que vinham visitar. 
O segundo espaço foi o das artes, no qual haviam materiais para que as crianças confeccionassem os personagens das histórias que haviam ouvido, dentre os materiais estavam à disposição das crianças rolinhos de papel higiênico, tintas, pincéis, folhas de ofícios, lápis de cor, canetinhas. 0 terceiro cantinho foi de lembranças do sarau, no qual as turmas fizeram um marca páginas com a identificação do sarau e shampoo mata piolhos (tendo em vista que há alunos que necessitam e é feito com produtos naturais) para distribuir para a comunidade. E o quarto cantinho foi o de troca-troca e doação de livros, neste havia um cartaz dizendo: Troque um sorriso por um livro, no qual os visitantes deveriam sorrir e levar qualquer livro para casa. No meio da sala, eles montaram um pequeno palco com duas cadeiras ao centro que era para receber as duas atrações do sarau, a escritora Jaqueline Marth e o músico recreacionista Rafael Marth.

O sarau que eles montaram foi muito bem-sucedido, a comunidade participou ativamente de todas as propostas, os pais trouxeram seus filhos para ouvir as histórias que estavam sendo contadas com fantoches. No espaço das artes, crianças e adultos fizeram seus personagens com os materiais disponibilizados. No espaço de troca-troca de livros, recebemos muitos sorrisos dos visitantes e a campanha lançada por eles "Troque um sorriso por um livro" beneficiou muitas famílias e incentivou a leitura dentro e fora da escola, o qual era nosso objetivo principal.

Suscitar o interesse pelos livros é indispensável para auxiliar no incentivo à leitura de todos. Solé (1998, p.43) salienta que:

O termo "motivação" é polissêmico, e por isso, sem qualquer intenção de exaustividade, gostaria de frisar com o entendo no âmbito da leitura. Parece-me que uma atividade de leitura será motivadora para alguém se o conteúdo estiver ligado aos interesses da pessoa que tem que ler e, naturalmente, se a tarefa em si corresponde a um objetivo.

Diante desta realidade, os futuros professores pensaram no sarau como um espaço que atendesse as necessidades de todos os visitantes, desde as crianças até os adultos que estavam acompanhando-a. Assim, organizaram os espaços de interação dos pequenos com os livros e fantoches através das contações de histórias que ocorreram e do espaço das artes, onde eles representavam os personagens. Por outro lado, os adultos conversaram sobre obras literárias e diferentes gêneros musicais.

Por volta das 11 horas e 45 minutos chegaram as atrações tão esperadas, a escritora Jaqueline Marth fez uma conversa com os visitantes que dividiam-se entre adultos e crianças, neste momento ela falou sobre suas duas obras publicadas "Papai sabe tudo" e "Aninha nas ondas do mar" e os desafios para publicação das mesmas e para atrair leitores numa era onde os hábitos de leitura são cada vez mais escassos. Ela reforçou com o público a importância de ler e contar histórias para as crianças pequenas para que se tornem leitores regulares desde a infância. Na sequência, ela fez um momento de contação de história no qual contou uma adaptação de um de seus livros "Papai sabe tudo", as crianças participaram ativamente desse momento respondendo a questionamentos e interagindo com ela, o músico recreacionista Rafael auxiliou a escritora cantando músicas infantis para as crianças.

Após as falas de Jaqueline o músico recreacionista Rafael conversou com a comunidade sobre diferentes gêneros musicais, e grandes cantores e bandas da atualidade e músicos consagrados do passado. 0 público do sarau pediu para que ele tocasse "Cowboy Fora-da-lei" de Raul Seixas e ele prontamente tocou e cantou, as pessoas cantaram entusiasmadas junto. Depois tocou atendendo pedidos as músicas: "Será" da Banda Legião Urbana, "Exagerado" do cantor Cazuza e "Aquarela” do cantor Toquinho.

Terminada a participação deles, o Sarau continuou em pleno funcionamento até as 15 horas com a participação de muitos visitantes que chegavam a todo momento para ouvir histórias, conversar sobre obras literárias, trocar livros e saberes. A partir das 15 horas, eles começaram a organização do espaço cedido para deixar pronto para as aulas na segunda-feira. Tiba (1996, p.140) afirma que:

O interesse e participação são fundamentais. A escola necessita saber que é uma instituição que completa a família, e que ambos precisam ser um lugar agradável e afetivo para os alunos/filhos. Os pais e a escola devem ter princípios muitos próximos para o benefício do filho/aluno.

Deste modo, a participação de todos foi muito importante para que pudesse ser realizado um evento de tamanha proporção na escola. A escola tem essa função de aproximar as famílias desse espaço que é deles. Foi muito gratificante ver os futuros professores trabalharem juntos com minha orientação, mostrando-se tão participativos para prestar esse serviço para a comunidade, fiquei muito feliz com o resultado, pois esse trabalho deles beneficiou uma comunidade inteira. 


\section{CONSIDERAÇÕES FINAIS}

Em virtude dos argumentos abordados na pesquisa, salientamos que a temática "Valorizando práticas de leitura dentro e fora da escola" torna-se pertinente em todos os campos da educação. Abordar tais assuntos é a melhor forma de enfrentar as problemáticas que temos hoje nas escolas e os baixos níveis de leitura. Deste modo, a participação de todos foi muito importante para que pudesse ser realizado um evento de tamanha proporção. A escola tem essa função, de aproximar as famílias desse espaço, que é delas. Foi muito gratificante ver os futuros professores trabalharem juntos, com minha orientação, mostrando-se tão participativos para prestar esse serviço à comunidade, fico feliz com o resultado, pois esse trabalho deles beneficiou uma comunidade inteira. A prática da leitura se faz presente, em cada um de nós, desde o momento de nosso nascimento, mesmo pequenos, a partir do momento que começamos a compreender e experimentar o mundo a nossa volta. Neste constante desejo de decifrar e interpretar o sentido do que nos cerca, de iniciar a perceber o mundo sobre diversas perspectivas, relacionando a realidade ficcional com a vivenciada, estamos de certa forma lendo, embora não seja um livro, lemos tudo a nossa volta sem nos dar conta. Assim, a leitura configura um instrumento libertário poderoso para transformações no mundo. A escola deve aproximar a comunidade escolar dessas práticas através de ações que visem o compartilhamento de saberes, pois é um espaço de socialização que se constitui um constante laboratório de aprendizagem.

\section{REFERÊNCIAS}

[1] ALÇADA, Isabel, Ana Maria Magalhães. Ler ou não ler: Eis a questão. Coleção Educação nº 3. Porto Alegre Ed.Kuarup, 1990.

[2] ALMEIDA Júnior, Oswaldo Francisco. Biblioteca Pública: avaliação de serviços/ Oswaldo Francisco de Almeida Júnior. Londrina: Eduel, 2003.

[3] ALLIENDE, Felipe. A leitura: teoria, avaliação e desenvolvimento/ Felipe Alliend e Mabel Condemarín; trad. Ernani Rosa. Porto Alegre: Artmed, 2005.

[4] BARBOSA, Maria Carmen Silveira, Maria da Graça Souza Horn. Projetos pedagógicos na Educação Infantil. Porto Alegre: Artmed, 2008.

[5] BRASIL, Ministério da Educação e Cultura. Utilização do Livro Didático, Brasil, 1970.

[6] DINORAH, Maria. O livro infantil e a formação do leitor/Maria Dinorah Luz do Prado. Petrópolis, RJ: Vozes, 1995.

[7] FERNANDES, Marlene. Gestão em educação/ Marlene Fernandes, Luciana Peixoto Cordeiro, Maria Cleidia Klein Oliveira. - Canoas: Ed. ULBRA, 2010.

[8] FERREIRA, Naura Syria Carapeto. Gestão e Organização Escolar. IESDE Brasil, 2009.

[9] HOFFMANN, Jussara Maria Lerch. Avaliação mediadora: uma prática em construção da pré-escola à universidade. Porto Alegre: Mediação, 2003.

[10] LAJOLO, Marisa. Do mundo da leitura a leitura do mundo/Marisa Lajolo-6.ed. São Paulo: Atica, 2000.

[11] LUCKESI, Cipriano Carlos. Avaliação da aprendizagem escolar: Apontamentos sobre a Pedagogia do Exame. Rio de Janeiro: Tecnologia, v. 20, p.82-86, jul-ago.1994.

[12] LUCKESI, Cipriano C. Avaliação de Aprendizagem Escolar. 6. ed. São Paulo: Cortez, 1977.

[13] LÜCK, Heloísa, Liderança em Gestão Escolar, 3. ed., Petrópolis, RJ: Vozes, 2009.

[14] LUCK, Heloisa, Ação Integrada, 23. ed.Petrópolis, RJ: Vozes. 2005.

[15] LUCK, Heloísa. A gestão participativa na escola. 8. ed. - Petrópolis, RJ: Vozes, 2010. Série cadernos de gestão.

[16] MACHADO, Lourdes Marcelino, coordenadora. Administração e supervisão escolar: questões para o novo milênio. Graziela ZambãoAbdian Maia organizadora. São Paulo: Pioneira Thomson Learning, 2003.

[17] MAGALHÃES, Ana Maria. Ler ou não ler: eis a questão/ Ana Maria Magalhães, Isabel Alçada. - Porto Alegre :Kuarup,1990.

[18] MONTOYA. Montoya e as reduções num tempo de fronteiras. Anais do VI Simpósio Nacional de estudos missioneiros. Santa Rosa/RS, 1985

[19] MARQUES, L. R. Projeto político pedagógico: construindo a autonomia da escola pública? As representações sociais dos conselheiros. 2000. Dissertação (Mestrado em Educação)-Universidade Federal de Pernambuco, Recife, 2000. 
[20] Projeto Político Pedagógico,Cachoeirinha. Instituto Estadual de educação Princesa Isabel, 2018.

[21] RODRIGUES, Edvânia Braz Teixeira. Cultura, arte e contação de histórias. Goiânia, 2005.

[22] SOLÉ, Isabel. Estratégias de leitura/ Isabel Solé; trad. Cláudia Schilling - 6.ed. Porto Alegre, 1998.

[23] TIBA, Içami. Disciplina; limite na medida certa. 41. ed. São Paulo: Gente, 1996, 240 p.

[24] ROSSI, Vera Lúcia Sabongi. Gestão do Projeto Político-pedagógico: entre corações e mentes. São Paulo: Moderna, 2004. (Coleção cotidiano escolar).

[25] ZIBERMAN, Regina. Lajolo Marisa. A formação da leitura no Brasil/ Marisa Lajolo e Regina Zilberman. São Paulo: Ática, 2003.

[26] ZABALA, A. A Prática Educativa: Como ensinar. Porto Alegre: Artmed, 1998. 


\section{Capítulo 14}

\section{A pesquisa com os cotidianos e a trajetória de uma docente de inglês no Ensino Fundamental II}

\section{Cláudia Botelho Silva \\ Inês Barbosa de Oliveira}

Resumo: 0 objetivo deste artigo é apresentar os resultados de uma pesquisa na área da educação, que teve dentre seus objetivos compreender as escolhas metodológicas feitas pela docente de língua inglesa durante as aulas para perceber se tais escolhas estavam relacionadas com sua formação acadêmica e trajetória docente, e se possibilitavam o desenvolvimento do inglês oral. Metodologia: trata-se de uma pesquisa qualitativa desenvolvida por meio de um "mergulho" na sala de aula de uma turma do sétimo ano, para observar o cotidiano escolar. Os dados foram produzidos por meio de observação de aulas e duas entrevistas semiestruturadas com a docente. Concluímos que a formação acadêmica da docente exerce forte influência na maneira como ela traça os objetivos das aulas e escolhe os métodos de ensino, e que é possível desenvolver a oralidade com os alunos independente do método utilizado.

Palavras-chave: Métodos de ensino de inglês, Cotidiano escolar, Trajetória docente. 


\section{INTRODUÇÃO}

0 presente trabalho é fruto das reflexões presentes na minha dissertação de mestrado que está inscrita no campo de políticas.

Nosso ponto de partida foi a ideia de que a aprendizagem do inglês pode ampliar a visão de mundo dos jovens do ensino fundamental, ainda que eles não tenham maturidade para compreender a importância de tal aprendizado em suas vidas. 0 papel da escola é sensibilizá-los, despertando o interesse para que venham a aprofundar-se mais no estudo do idioma no futuro.

Faz-se necessário que as práticas docentes sejam desinvizibilizadas, no sentido do reconhecimento de que há muita coisa de qualidade acontecendo dentro dos muros das escolas públicas. Elas precisam ser mostradas à sociedade que acaba reproduzindo as falas daqueles que desconhecem o real valor do espaço público de produção de conhecimento.

No presente artigo, partimos das reflexões produzidas a partir das entrevistas com a docente e focamos nas questões das escolhas metodológicas para o ensino do inglês, e se tais escolhas contribuíram para o desenvolvimento do inglês oral.

Assim, registramos e analisamos elementos da história de vida da professora da turma, do ponto de vista da trajetória pessoal e acadêmica que dialogaram com suas escolhas metodológicas e com as práticas efetivamente desenvolvidas. Fizemos isso com vistas a entendermos se as metodologias escolhidas têm foco prioritário no ensino da gramática ou no desenvolvimento da habilidade oral. Entendemos que, com isso, esse estudo contribuirá para um adensamento da discussão em torno do ensino do inglês nas escolas regulares.

\section{METODOLOGIA}

Como nossa pesquisa envolveu seres humanos, antes de iniciá-la, submetemos o projeto de pesquisa ao Comitê de Ética em Pesquisa (CEP) da Plataforma Brasil. O projeto intitulado "Pesquisando sobre o desenvolvimento da oralidade do inglês em contexto de escolas públicas regulares" está registrado sob o número de CAAE (Certificado de Apresentação de Apreciação Ética): 04095918.7.0000.5284.

Todos os alunos que participaram da pesquisa assinaram o Termo de Assentimento (TA) e os pais o Termo de Consentimento Livre e Esclarecido (TCLE), a professora também assinou o TCLE. Além disso, obtivemos a consentimento da Direção da escola para a realização da pesquisa através de documento assinado pela própria Direção.

Após a fase de submissão do projeto para apreciação e consequente aprovação na Plataforma Brasil, demos início à pesquisa na Escola Estadual de Ensino Fundamental Henrique Lage, que é uma escola da rede pública estadual da rede Fundação de Apoio à escola Técnica (FAETEC), subordinada à Secretaria de Ciência e Tecnologia. Esta escola encontra-se situada no bairro Barreto, considerado um bairro de periferia, na cidade de Niterói-RJ. A escolha da escola se deu pelo fato de eu já ter trabalhado lá durante dez anos (2000-2011) o que facilitava o meu trânsito na escola, além de ser, também, uma escola pública.

Enquanto observava as aulas, questionamentos me surgiam sobre a prática docente da professora, e foi somente a partir do contato com o cotidiano das aulas que preparei as perguntas para as duas entrevistas semiestruturadas que fiz com a regente da turma. Com a devida autorização da docente, gravei suas falas e as transcrevi, produzindo os dados.

\section{REFERENCIAL TEÓRICO}

Nossa pesquisa se desenvolveu na perspectiva metodológica das pesquisas nos/dos/com os cotidianos das escolas (ALVES; GARCIA, 2008; OLIVEIRA; ALVES, 2008; OLIVEIRA; SGARBI, 2008) e a partir da observação do cotidiano de uma turma de sétimo ano do Ensino Fundamental, considerando, como sugere essa abordagem metodológica, o espaço escolar como um todo, para além daquilo que ocorre na sala de aula.

Optamos pelo uso do plural nos/dos/com para demonstrar a pluralidade presente no cotidiano, uma vez que ele é um fenômeno que acontece em rede. Portanto, todos os ambientes escolares contam, pois o nosso olhar transcende o que acontece na sala de aula. 
A escolha pela pesquisa com os cotidianos deve-se à compreensão de que o cotidiano é um espaço de criação, é um espaço onde aquilo que está previsto se modifica pela ação dos sujeitos, pelos conhecimentos anteriores, pelas capacidades, pelas condições de trabalho e por tantas outras razões que fazem de cada realidade uma experiência diferente de todas as outras (CERTEAU, 1994). Acreditamos, ainda, que o conhecimento se tece em redes em que todos esses aspectos se relacionam e interagem. Portanto, para saber como se desenvolve o que está previsto, é preciso estar presente no ambiente que pretendemos investigar (OLIVEIRA e ALVES, 2008).

As pesquisas nos/dos/com os cotidianos, embora utilizem procedimentos de pesquisa comuns a outras metodologias qualitativas, têm suas peculiaridades

Quando estamos mergulhados no cotidiano, vemos os detalhes. Ao passo que de longe não os vemos, Certeau (1994). Do alto, eu vejo tudo, mas não compreendo nada. Só conseguimos essa percepção quando estamos andando. Pois, quanto mais longe, menos se percebe o que se está vendo, por conseguinte, somente quando mergulhamos é que vamos compreender o que estamos vendo.

A ideia da modernidade é de que o observador tem que ter um olhar externo, ele tem que se distanciar do objeto. E quando estamos longe, o único sentido que usamos é a visão, ou seja, o sentido privilegiado na perspectiva moderna é a visão, não sentimos os cheiros, não escutamos. E como não sentimos os acontecimentos, explicamos o que vemos. Ao passo que as pesquisas nos/dos/com os cotidianos objetivam compreender os fenômenos para traçar estratégias locais de ações pontuais, que possam vir a contribuir para a melhoria da realidade escolar pesquisada. Não buscamos generalizações, pois nossa pesquisa parte do microcosmo, a sala de aula, portanto, nossas conclusões estão circunscritas ao ambiente pesquisado, que exemplifica um dos modos possíveis de ocorrência, mas não pode definir o conjunto de possibilidades.

O cotidiano escolar é um processo em construção. A escola não é, ela está sendo, ela acontece todo dia. Existe um dinamismo permanente de construção. Um olhar congelado não dá conta desse cotidiano.

Não achamos que a escola seja uma maravilha, mas já tem gente demais falando muito mal dela, portanto, decidimos destacar os aspectos positivos da realidade escolar. 0 ideal passa por verdade na narrativa hegemônica do Governo. Muitas das críticas que são feitas à escola partem de um ideal que não existe: alunos com todo o material, etc.

\section{RESULTADOS E DISCUSSÃO}

\subsection{UM POUCO SOBRE UM DOS NOSSOS MERGULHOS NA SALA DE AULA DA TURMA 701}

Mergulhamos no cotidiano das aulas de inglês ministradas na turma 701 no ano de 2019, numa escola de ensino fundamental localizada no Bairro Barreto, na cidade de Niterói- RJ.

A aula inicia com a professora escrevendo no quadro as regras de formação do Simple Present. Portanto, temos o ensino da gramática como o objetivo central da aula. Os alunos copiam do quadro.

Quando termina de escrever, ela, imediatamente, inicia a explicação dos usos do Presente Simples, em inglês. Os alunos prestam a atenção à explicação e respondem às perguntas de sondagem da compreensão que ela faz. Enquanto eles finalizam a cópia do quadro, ela distribui as folhas do exercício que ela preparou para que eles pratiquem a estrutura verbal que ela está ensinando.

\section{Considerações sobre a aula observada:}

O aprendizado de regras gramaticais pertinentes à língua-alvo é importante, uma vez que, a partir de tal conhecimento, o aluno poderá formular frases com mais segurança, pois a gramática funciona como um tipo de alicerce de todo idioma.

Nosso sistema educacional prioriza o ensino conteudista, formalista e desvinculado de objetivos para a vida cotidiana. Um grande número de escolas tem como objetivo de seu Projeto Político-Pedagógico que seu corpo discente obtenha bons resultados nos exames nacionais, como o Sistema de Avaliação da Educação Básica (Saeb) e o Exame Nacional do Ensino Médio (Enem). Pelo menos em sua formulação, o Projeto Político Pedagógico (PPP) da escola que fez parte da nossa pesquisa não reproduz isso e afirma visar à formação dos alunos como um todo, acadêmica e humanamente falando.

As respostas da professora dão corpo a uma narrativa que nos possibilita compreender traços da sua prática docente que vão além das respostas verbalizadas. Ao falar de sua história de vida privada e 
docente, a professora nos permite tecer fios que nos levam a uma melhor compreensão do que acontece na sala de aula e sobre sua prática docente.

Sobre as metodologias de ensino de inglês escolhidas pela docente para trabalhar com os alunos

Pesquisadora: Fale-me sobre suas escolhas metodológicas para as suas aulas e as razões que as motivam.

Ana: Bom, razões que motivam a minha escolha: número de alunos, nível de cada turma(...) (...)Os alunos vão ter mais dificuldade e trabalho muito com a gramática e com o vocabulário, até porque quando eu fiz pósgraduação, meu foco foi em gramática, no ensino da gramática e eu trabalho essa parte, mas também tento trabalhar dentro de um contexto, dentro de temas.

O livro didático já vem dividido assim em temas. Então a unidade 1 vai trabalhar tal tema, etc. Eu tento unir a gramática, trabalhar um tópico gramatical, em seguida, eu já prevejo um tópico gramatical e seleciono o tipo de vocabulário que eu possa expandir de acordo com o tema proposto, é assim que eu tento trabalhar.

A docente evidencia, nesse relato, sua dificuldade em escolher a metodologia de ensino do idioma. Sua formação docente e o quantitativo de alunos em sala de aula seguem como guia na escolha do método de ensino. Ela pontua, ainda: “(...) porque quando eu fiz pós-graduação, meu foco foi em gramática, no ensino da gramática e eu trabalho essa parte, mas também tento trabalhar dentro de um contexto, dentro de temas". Ou seja, sua narrativa nos indica que a escolha metodológica se relaciona com aquilo que se sente capaz de fazer, no campo que conhece melhor e no qual, portanto, se sente mais à vontade.

Ela utiliza o método Gramática Tradução, o Situacional e o de Leitura. Ela escolhe o método de acordo com o objetivo da sua aula, variando, portanto, conforme a circunstância.

\section{Sobre a prática docente e as contribuições do campo da didática}

Pesquisadora: Como sua prática docente dialoga com a formação docente que você vivenciou na Universidade? Ou seja, a maneira como o seu programa de formação docente te ensinou a trabalhar e como você efetivamente construiu sua prática pedagógica.

Ana17: (...) eu não tive muito professor que pensava naquela coisa de educação bancária, igual tinha educação bancária, que se fala, né(...) (...) Pelo contrário, na minha formação docente, os professores trabalhavam muito tentando desconstruir essa coisa do professor como transmissor de conhecimento e na verdade encarando o professor como mediador, ele tá ali pra mediar o que tá acontecendo na sala de aula, o conhecimento, levando em consideração que o aluno já sabe e tentando acrescentar aquilo ali. Aí foi isso que eu tive na faculdade e nos cursos que eu fiz. Então eu tento fazer justamente isso, se for trabalhar um texto, previamente, eu tento ver o que o aluno já sabe a respeito daquele assunto, tento motivá-lo a colocar o seu conhecimento prévio para dialogar com o assunto da aula.

Após ter trabalhado em várias instituições de ensino, a professora foi fazendo ajustes na sua forma de ensinar sempre procurando se adaptar aos anseios dos alunos e da instituição onde trabalhava. Podemos afirmar que o professor é um profissional, cuja formação está em constante desenvolvimento.

A docente pontua, ainda, que o planejamento das suas aulas tem como ponto de partida a realidade dos alunos. Sua prática docente dialoga com o pensamento dos seus professores durante sua formação docente, a ideia de que o professor deve ser mais do que um simples transmissor de conteúdos, que deve buscar atrelar seu planejamento à realidade discente.

\footnotetext{
17 Usamos um nome fictício para preservar a identidade da professora.
} 
Pesquisadora: Fale-me sobre o papel da didática na sua formação docente e como ela dialoga com sua prática docente hoje? Me refiro às suas escolhas metodológicas.

Ana: Como eu trabalhei muito em curso, e falava muito do método comunicativo18, eu tinha muito disso. Mas às vezes, com as turmas grandes e heterogêneas, eu não conseguia trabalhar de acordo com os pressupostos desse método. Então o que eu uso mais, em termos de metodologia, é um inglês instrumental mesmo, a leitura e alguma coisa de produção escrita (...) (...)Portanto, meu foco era um inglês instrumental.

A docente relata que, apesar de considerar o método comunicativo um bom método, sempre optou por utilizar o método Gramática Tradução em suas aulas devido às questões operacionais como a do número de alunos em sala de aula, pois nas escolas de idiomas privadas, o número de alunos é reduzido, sendo o máximo 20 alunos por turma. Por esse motivo, muitos professores acreditam que a metodologia comunicativa só terá êxito caso seja trabalhada dentro de condições semelhantes às que as escolas de idiomas possuem.

A nova BNCC diz que "cai por terra a ideia de exigir que o aluno produza um inglês correto, do contrário, não sabe falar inglês" (BRASIL, 2017, p. 241). Reafirma, portanto, pressupostos do método comunicativo, que procura buscar um equilíbrio entre o ensino das funções da língua e das estruturas gramaticais. Uma das características principais é o trabalho em pares, em que os participantes interagem ou participam em algum tipo de transação: um dos participantes tem uma intenção e seu interlocutor expande a conversa ou reage ao que escutou.

A maioria dos professores de escolas regulares considera a questão do barulho em sala como o maior obstáculo para o trabalho com a habilidade de escuta, que leva os alunos a desenvolverem a fala. Portanto, optam em focar na habilidade de leitura e tradução e raramente chegam a desenvolver trabalhos de produção escrita também.

As minhas observações de aulas e minha própria prática docente me mostraram que não é impossível o desenvolvimento da habilidade oral, porém, tal processo demanda um planejamento maior da parte do professor das escolas regulares, focando em certos ajustes logísticos para que uma metodologia que priorize o desenvolvimento da oralidade possa ser utilizada.

\section{Como nossa entrevistada aprendeu a língua inglesa}

Pesquisadora: Então, Aline, me fala um pouco sobre como se deu o seu aprendizado da língua Inglesa.

Ana: 0 meu aprendizado não se deu tão cedo assim, eu comecei a estudar com 13 anos, e foi uma coisa!Eu não era tão criança, foi uma decisão dos meus pais por uma questão de eu ter que aprender uma outra língua, e o inglês na época que eu comecei a aprender, e ainda hoje, é a língua que todo mundo aprende primeiro como língua estrangeira.

Pesquisadora: Mas, você gostava? Era uma vontade sua? Ou foi mais dos seus pais?

Ana: Foi mais dos meus pais, foi imposição total, eu não queria fazer o curso, mas a primeira aula que eu assisti, eu já adorei, e o método era aquele método... não era comunicativo na época, era áudio-lingual, né?!Era do $\mathrm{CCAA}^{19}$. Mas, assim, eu gostei, e já me identifiquei como minha matéria favorita.

\footnotetext{
180 método comunicativo busca trabalhar as quatro habilidades da língua: escuta, fala, leitura e escrita. Esse método parte da ideia de que toda e qualquer enunciação linguística carrega os significados e intenções de seus falantes e escritores. Consequentemente, o objetivo principal desse método é desenvolver a proficiência comunicativa de seus falantes em vez de objetivar a maestria gramatical da parte dos alunos.

19 O Centro Cultural Anglo Americano (CCAA), era um dos cursos que mais fazia sucesso nos anos 1980, ano em que nossa entrevistada começou a estudar o idioma. A primeira coisa que nos chamou a atenção foi o fato desta escola de idiomas utilizar o método audiolingual, ela também, narra que se identificou com o método, desde o primeiro dia de aula. 0 método audiolingual dá grande ênfase à parte gramatical no ensino do idioma. Ela menciona também o método
} 
Pesquisadora: Então você fez o curso todo no CCAA?

Ana: Fiz, e quando eu comecei a fazer o curso, e eu me identifiquei, eu já tinha decidido que era "isso que eu ia fazer", antes eu não sabia exatamente com o que eu queria trabalhar (...)

A professora Ana aprendeu inglês através da metodologia audiolingual, Na época da criação do Audiolingualism, a teoria behaviorista, cujo principal expoente era o psicólogo Skinner (1957), estava em alta. De acordo com essa teoria, dominar uma língua significa adquirir um conjunto apropriado de estímulos e respostas. Depreendemos da sua fala que, como ela aprendeu o idioma através dessa metodologia, essa também foi a primeira metodologia de ensino de idioma com a qual ela teve contato. Consequentemente, há uma grande chance de ela querer reproduzir essa metodologia em suas aulas. Eu formulei essa

pergunta, pois já tinha percebido nas aulas observadas traços pertinentes ao audiolingualismo. E quando ela diz que não aprendeu inglês com uma metodologia comunicativa, me parece que ela acredita que o método comunicativo traz resultados mais eficazes para um ensino do idioma com foco no desenvolvimneto da fluência oral. Essa hipótese foi confirmada na primeira entrevista quando ela disse que gostava do método de ensino da Cultura Inglesa, que é o método comunicativo, as falas abaixo ilustram nossa conclusão.

As falas da docente sinalizam seu desejo de ter o desenvolvimento da oralidade como o foco de suas aulas.

\section{Formação Docente}

Pesquisadora: E você fez sua graduação onde?

Ana: Eu comecei na UERJ20, fiz um ano de licenciatura, mas decidi que eu não queria dar aula. Aí eu fui buscar outra coisa na área de inglês, na área de língua. Aí eu fiz um curso de tradução no IBEU21, na Tijuca,22 na época, aí eu fiz 1 ano, gostei... aí eu disse: é isso que eu quero fazer, tradução. Só que na época, eu com 17 pra 18 anos, não tinha nenhum curso com tradução aqui, em São Gonçalo23, nem em Niterói24. 0 único curso que tinha era na Gávea, era na PUC25(...)

Pesquisadora: Então, você fez a sua graduação em Letras na PUC.

Ana: Foi. E eu saí Bacharel em tradução, porque eu não fiz licenciatura. Só que enquanto eu fazia... Na verdade, assim, com 16 anos eu tive a minha primeira experiência em magistério, e foi em uma turma de 1a a $4^{a}$ série, numa escola em Santa Izabel (bairro de São Gonçalo) (...)

Depois, voltando à faculdade, enquanto eu fazia faculdade, que eu tinha decidido fazer Tradução, eu comecei a dar aula em curso, pra ter uma renda, né?!

Pesquisadora: E qual foi o primeiro curso? Você lembra?

Ana: 0 primeiro curso foi... que eu dei aula, foi o CNA26. Tinha um CNA em frente à minha casa.

Pesquisadora:Você voltou para fazer uma complementação pedagógica?

Ana: Não, eu ainda estava fazendo faculdade.

comunicativo, nos dando a entender que caso seu aprendizado tivesse acontecido nos dias atuais, ela teria aprendido através dele.

20 Universidade do Estado do Rio de Janeiro.

21 Instituto Brasil Estados Unidos.

22 Bairro situado na cidade do Rio de Janeiro.

${ }^{23}$ Cidade situada no estado do Rio de Janeiro.

${ }^{24}$ Cidade situada no estado do Rio de Janeiro.

25 Pontifícia Universidade Católica.

${ }^{26}$ Cultural Norte-Americano é uma rede de escolas de idiomas privada brasileira, com foco no ensino de inglês e espanhol, fundada por Luiz Nogueira da Gama Neto. Disponível em www.wikipedia.org. Acesso em 01/07/2019. 
Pesquisadora: Então, você acabou Tradução e começou a fazer outra faculdade?

Ana: Enquanto eu estava fazendo a faculdade de Tradução, eu estava dando aula também... quer dizer, eu voltei a dar aula.

Pesquisadora: Mas, aí você fez uma complementação pedagógica ou não?

Ana: Fiz. Depois do curso de Tradução... como eu já tava dando aula, eu pensei: Agora, eu quero fazer concurso, né?! E pra fazer concurso, eu tinha que ter licenciatura. Só que quando eu fiz minha licenciatura, eu fiz só em inglês, eu não sou professora de Português. Eu sou professora de Inglês, só.

Ana: (...) Aí depois desse curso, eu já estava com o diploma de professora. Eu já podia fazer concurso. E o mercado de tradução... muito fechado. Eu cheguei a fazer estágio, mas... a gente não saía da faculdade para o mercado de tradução, saía para o mercado de "professor" mesmo, de licenciatura. E eu já estava nele, na verdade, e acabei voltando.

Constatamos, no relato da professora sobre sua formação docente, que ela teve uma formação inicial como tradutora, mas o mercado de trabalho a fez mudar de planos e optar pelo magistério. Desde a adolescência, a professora encantou-se com a língua inglesa, porém, não fez planos para tornar-se professora, as coisas foram acontecendo, e de modo não planejado, e ela se tornou professora.

Pesquisadora: Você acredita que exista algum recurso material que possa facilitar o processo ensino- aprendizagem?

Ana: Uma coisa que seria um ideal, seria um sonho, seria uma sala temática, né. De inglês, língua inglesa. Turmas divididas, que eu até já vi em outros colégios. Assim, um projeto que fizesse como se fosse mesmo um curso dentro colégio. Desta forma teríamos um número de alunos que possibilitaria que trabalhássemos as quatro habilidades, que nos permitiria ensinar os alunos a falar, a aprender a ouvir...

Aqui a professora se refere ao método comunicativo, aquele que é utilizado em cursos privados de inglês, como a Cultura Inglesa.

Pesquisadora: Caso as salas de aula temáticas existissem, qual habilidade você acredita que deveria ser priorizada?

Ana: Atualmente, eu acho que eu iria priorizar a "fala", a comunicação oral dos alunos. Se eu fosse priorizar alguma coisa.

Pesquisadora: E você acha que não dá para priorizar a "fala" por conta do ...

Ana: Por conta do quantitativo de alunos, por falta de material mesmo, de infraestrutura, uma sala que comportasse os alunos.

Nesse relato, nos deparamos com o imaginário do "contexto ideal" para que a oralidade do idioma possa ser trabalhada com os alunos. Existe a crença de que a oralidade do idioma somente poderá ser desenvolvida caso tenhamos as condições materiais similares àquelas encontradas nas escolas de inglês privadas. Essa crença é compartilhada pela grande maioria dos docentes de língua inglesa. Mas na prática, sabemos que essas condições ideais estão longe de serem atingidas. Considerando, no entanto, as possibilidades concretas de criação em diálogo com o que a realidade oferece, entendo que cabe a nós, docentes, criarmos estratégias e buscarmos metodologias que nos permitam trazer o inglês oral para dentro das salas de aula de escolas regulares, dentro dos limites e possibilidades de cada realidade escolar, como já fazemos em muitos casos.

Ana: 0 ideal seria que tivéssemos mais professores trabalhando em um projeto, né. Sendo que aqui na escola, temos poucos professores de inglês, não temos coordenador de área, então são poucos professores, e todos já estão cumprindo toda a carga horária que devem cumprir. Ou seja, não temos tempo fora de sala para desenvolver um projeto em conjunto. 
A professora pontua a falta de tempo para trabalhar colaborativamente, que é outro problema enfrentado nas escolas. A meu ver, este problema supera a falta de condições físicas de trabalho. 0 trabalho em equipe seria de grande valia para suplantar grande parte dos obstáculos que encontramos no dia a dia da escola.

Ainda assim, trabalhamos e procuramos levar nossos alunos a aprendizagens importantes, conforme confirma nossa entrevistada ao ser perguntada sobre sua prática docente.

Concluímos, portanto que há pontos de contato entre as escolhas metodológicas registradas em sala de aula e a trajetória de aprendizado da língua inglesa da docente de nossa pesquisa. E além disso, podemos dizer que existe a possibilidade de desenvolvimento do inglês oral durante todas as aulas, partindo da teoria da complexidade de Egard Morin.

No campo da complexidade, Edgar Morin (2018, p. 181) nos traz a ideia do princípio hologramático. Segundo ele,

Holograma é a imagem física cujas qualidades de relevo, de cor, e de presença são devidas ao fato de cada um de seus pontos incluírem quase toda a informação do conjunto que ele representa. Nós temos esse tipo de organização nos nossos organismos biológicos; cada uma de nossas células, até mesmo a mais modesta célula da epiderme, contém a informação global.

Em se tratando da escolha metodológica feita por um professor de inglês em uma aula, digamos que ele escolha o Método Gramática Tradução. Refletindo sobre essa metodologia sob a ótica do princípio hologramático, podemos dizer que o método Gramática Tradução traz em si características de todos os outros métodos existentes para o ensino do idioma. Desta forma, não teremos apenas a aprendizagem de tradução de palavras, uma vez que o aluno estará ouvindo as frases, e desenvolvendo a habilidade da escuta (listening), ao mesmo tempo em que estará desenvolvendo a oralidade através da leitura (reading/speaking), e estará treinando a escrita (writing) com os exercícios escritos. Dependendo do objetivo de cada aula, um certo traço ou uma certa habilidade da língua será mais enfatizada. Dessa forma, concluímos que as quatro habilidades da língua: escutar, falar, ler e escrever estão presentes em todas as aulas, pois o todo está nas partes e as partes estão no todo, como também aprendemos com Morin.

As informações trazidas pela empiria apontam para o fato de ser possível desenvolver a oralidade em ambiente de escolas regulares. Nosso objetivo de pesquisa não era medir se a oralidade desenvolvida entre os aprendizes geraria ou não proficiência no idioma, tampouco o seu grau. Sugerimos estudos futuros para compreender o grau da proficiência da oralidade dos estudantes de escolas regulares.

\section{CONSIDERAÇÕES FINAIS}

Registramos e analisamos os elementos da história de vida da professora da turma 701 e concluímos que a formação docente que ela recebeu e a experiência adquirida em seu início de carreira influenciaram e ainda influenciam de forma expressiva sua prática docente.

A professora aprendeu a língua inglesa com o método audiolingual, que enfatiza o aprendizado das estruturas gramaticais do idioma. Assim, pudemos perceber que o ensino da gramática era presente em suas aulas. Ela também tem formação em Tradução, essa informação nos leva a compreender a ênfase dada à tradução nas suas aulas.

As aulas observadas nos brindaram com um dia a dia cheio de aprendizado em língua inglesa, e com alunos engajados e motivados para aprender o idioma. A oralidade do inglês esteve presente em todas as aulas, principalmente sob a ótica da teoria da complexidade de Edgard Morin (2018).

As entrevistas com a professora nos ajudaram na compreensão da ideologia que subjaz suas escolhas metodológicas, e mais do que isso, nos possibilitaram captar os pontos de contato entre sua fala, na qual ela descreveu seu caminho de aprendizado da língua inglesa e sua posterior trajetória docente. 


\section{REFERÊNCIAS}

[1] ALVES; GARCIA, Regina Leite. O sentido da escola. 5.ed. Petrópolis: DP e Alii, 2008.

[2] BRASIL. Base Nacional Comum Curricular. 2017. Disponível em: <basenacionalcomum. mec.gov.br/abase>.

[3] CERTEAU, Michel de. A invenção do cotidiano: 1. artes de fazer. Petrópolis: Vozes, 1994.

[4] MORIN, Edgar. Ciência com consciência. 17. ed. Rio de Janeiro: Bertrand Brasil, 2018.

[5] OLIVEIRA; ALVES, Nilda. Pesquisa nos/nos/com os cotidianos das escolas. Sobre redes de saberes. Petrópolis: DP et Alli, 2008.

[6] ___ _ SGARBI, Paulo. Estudos do cotidiano \& Educação. Belo Horizonte: Autêntica Editora, 2008. (Coleção Temas \& Educação.) 


\section{Capítulo 15}

\section{A escola do campo e a valorização da identidade cultural dos educandos do Ensino Médio do assentamento 40/45 em Alcobaça - Bahia}

\section{Erivelton Santos Rodrigues}

Yolanda Aparecida de Castro Almeida

Resumo: 0 presente artigo é uma reflexão sobre a educação do campo e a formação humana a partir da valorização da identidade dos educandos frente a uma lógica global que tende a homogeneização dos sujeitos. Objetiva oferecer elementos para compreender de que maneira a Escola Estadual Vinte e Cinco de Julho - Extensão Assentamento 40/45, localizada na zona rural do município de Alcobaça - Bahia, se organiza e trabalha para a formação, afirmação e valorização da identidade cultural dos seus educandos perante o mundo globalizado. Este é um estudo de caso, no qual priorizou-se o método qualitativo e para coleta de dados utilizou-se observação participante e entrevistas semiestruturadas com os professores e secretária autorizada da referida escola. Caldart, Arroyo e Woodward formam a base teórica desse artigo, os dois primeiros por serem referências no que concerne à educação do campo no Brasil e a última por seus estudos sobre identidade cultural no mundo contemporâneo. Percebeuse que, apesar dos avanços nas últimas décadas, a educação do campo da Bahia ainda apresenta dificuldades na implementação das políticas públicas que respalda essa modalidade de ensino. A falta de suporte pedagógico apresenta-se como um dos principais problemas no que diz respeito a implementação de um modelo de educação voltado à valorização da identidade dos sujeitos do campo perante o mundo que tende à homogeneização cultural dos indivíduos.

Palavras-chave: Educação, Campo, Identidade. 


\section{INTRODUÇÃO}

O artigo em questão foi produzido com base na dissertação de mestrado que tem como tema "As práticas pedagógicas e a valorização da identidade cultural dos educandos do campo". No decorrer da pesquisa buscou-se elementos que comprovassem a maneira pela qual a escola do campo corrobora a valorização e afirmação das identidades dos seus educandos frente ao mundo globalizado.

No mundo atual é inviável refletir as áreas rurais enquanto guetos, isolados do mundo moderno, inclusive, muitas vezes, não se pode negar que o campo e a cidade, que outrora representavam espaços antagônicos, encontram-se cada vez mais interligados. Alguns fatores contribuíram e contribuem para intensificação da interação entre campo e cidade, com destaque para o aumento da malha viária, das transações comerciais existentes entre os espaços rurais e urbanos e pela implementação no campo de recursos tecnológicos como a energia elétrica, o rádio, a televisão e em ainda em menor escala, a internet.

Contudo, é notório que existem diferenças históricas e culturais entre o campo e a cidade, e que estas diferenças, muitas vezes, não estão recebendo a devida consideração no que se refere às práticas pedagógicas. 0 cotidiano vivenciado pelas pessoas, as relações que são constituídas numa comunidade, a forma como estas pessoas constroem os seus valores são elementos primordiais na constituição da identidade de um povo e, por isso, acredita-se que devem ser respeitados pelas propostas educacionais.

De acordo com Caldart (2004), os camponeses e camponesas ${ }^{27}$, e, por conseguinte, seus familiares, têm uma raiz cultural distinta dos indivíduos urbanos tornando-os culturalmente diferentes na forma de se relacionarem com o meio e com os outros. Quanto mais forem ressaltadas as especificidades do homem e da mulher do campo, mais se faz necessário uma educação específica para os mesmos.

Não obstante, a proposta para a educação no campo elaborada pelos movimentos de luta pela terra, com destaque para o Movimento dos Trabalhadores Rurais sem Terra (MST), é estruturada em escolas do campo que contribuam para a formação, afirmação e valorização da identidade cultural dos povos camponeses. Mas, em que medida esta ideia de pertencimento e identidade vem ocorrendo nas escolas do campo? De que maneira os educadores do campo percebem e reagem diante da globalização que tende a homogeneizar pensamentos e comportamentos?

Nessa perspectiva, esse trabalho tem como escopo oferecer elementos para compreender de que maneira o Colégio Estadual do Campo Vinte e Cinco de Julho - Extensão Assentamento 40/45, localizado no município de Alcobaça - Bahia, contribui para a formação, afirmação e valorização da identidade cultural dos seus educandos perante o mundo globalizado.

Para tentar alcançar o objetivo proposto optou-se pelo método qualitativo, dado o caráter social da pesquisa. Destarte, foram utilizadas entrevistas semiestruturadas com o corpo docente e administrativo da instituição escolar supracitada, visando ampliar a percepção que os mesmos têm da educação no campo.

Diante das respostas e percepção dos sujeitos entrevistados, verificou-se a ausência do Estado na valorização da cultura e educação do campo, no que concerne à assistência material da escola (livros didáticos, Tecnologias de Informação e Comunicação - TICs), ausência de coordenação pedagógica, inexistência de capacitação do corpo docente para atuar na educação do campo. Nesse contexto, dificultando o trabalho administrativo e pedagógico, o que resulta, entre outros, na desvalorização da cultura dos camponeses e camponesas do Assentamento 4045.

\section{METODOLOGIA}

Trata-se de uma pesquisa aplicada, de caráter exploratório na qual priorizou-se pelo método qualitativo. Por se tratar de uma pesquisa de cunho social acredita-se que alguns significados como valores, identidade, cotidiano e relações sociais são difíceis de serem quantificadas, ou seja, busca-se aqui a análise de relações e fenômenos que não podem ser reduzidos a operações e variáveis. Para Triviños (1987),

É interessante salientar, uma vez mais, que o pesquisador, orientado pelo enfoque qualitativo, tem ampla liberdade teórico-metodológica para realizar seu estudo. Os limites de sua iniciativa particular estarão exclusivamente fixados pelas condições da exigência de um trabalho científico (TRIVIÑOS, 1987, p. 133)

\footnotetext{
${ }_{27}$ Entende-se por camponeses e camponesas aqueles indivíduos que apresentam uma ligação íntima com a terra, que vive no campo e trabalha no campo.
} 
Como instrumento de coleta de dados, utilizou-se entrevistas semiestruturadas com os três professores, que atualmente lecionam na escola e com a secretária autorizada, que no momento da pesquisa respondia pela unidade de ensino. Todos os entrevistados assinaram um termo de consentimento livre e esclarecido, autorizando o uso das suas falas na pesquisa, porém sem identificação dos nomes dos mesmos. Utilizou-se, também, para coleta de dados a pesquisa documental e a observação participativa.

\section{REFERENCIAL TEÓRICO}

\subsection{A CONSTRUÇÃO DA IDENTIDADE E A EDUCAÇÃO DO CAMPO}

Quando nascemos encontramos um meio humano, constituído com sua língua, seus costumes, sua moralidade, sua religião, sua organização política e sua história específica. Tudo que pensamos, dizemos, percebemos se encaixa em um meio humano, no qual nos familiarizamos e nos enquadramos. Esse contexto pré-estabelecido desvenda a existência da chamada cultura. (SAVIANI, 1981)

A cultura, atributo próprio dos seres humanos, tem várias concepções dentro de algumas áreas de conhecimento, como a antropologia, a pedagogia, a sociologia, entre outras. De acordo com Forquin (1993), diz respeito às crenças, valores, costumes, comportamento humano, propriedades comuns de uma comunidade em questão. Sendo assim, sociologicamente, a cultura não pode ser estudada individualmente, mas sim em coletivo num determinado espaço, que comumente é sucessivo, portanto, ela resulta da comunicação entre as pessoas, sendo esse convívio imprescindível em qualquer sociedade.

Ao definir identidade, Woodward (2000) sugere que as identidades são marcadas pela existência de um conjunto resistente, único, de características, que agrupamentos de indivíduos apresentam com fortes laços de interação. Para a autora estas características são resistentes perante o tempo. Quando pensamos em pessoas que nasceram no campo, ou vivem há tempos nesses espaços, que sobrevivem em pequenas propriedades rurais, comumente pensamos em indivíduos que apresentam uma relação forte com a terra. São indivíduos que possuem uma forma singular de se relacionar com o meio, de trabalhar, de se relacionar com seus pares e que tende a resistir ao tempo e as opressões.

Ainda para a autora a identidade é relacional, ela não existe sozinha, necessita-se de um comparativo, um algo diferente que contraste com ela mesma. Da síntese desta contradição nasce a ideia da essência daqueles que pertencem e os que não pertencem a um determinado grupo identitário, ou seja, é a possibilidade, segundo a autora, de dividirmos os grupos sociais em "nós e eles".

No mundo contemporâneo discutir identidade se tornou uma tarefa muito complexa, pois o avanço do processo de globalização vem contribuindo intensamente para a homogeneização cultural. As melhorias dos meios de comunicação de massa, como televisão e internet, se apresentam como eficientes instrumentos na construção de novas identidades causando uma verdadeira "crise da identidade".

A escola, por sua vez, se apresenta como espaço de construção e reprodução de conhecimentos. As relações estabelecidas em âmbito escolar propiciam um conjunto de relações que permitem aos indivíduos que as vivenciam trocas de experiências capaz de fomentar a afirmação, a valorização ou até mesmo negação da cultura e da identidade de seus atores. Para Arroyo (2004, p. 14) "A escola pode ser um lugar privilegiado de formação, de conhecimento e cultura, valores e identidade das crianças, adolescentes, jovens e adultos". A ideia exposta por ele é que a escola seja capaz de ampliar a forma de seus educandos enxergarem o mundo e a si mesmos a partir de sua identidade, valores e culturas.

Entretanto, diante da conjuntura em que as escolas localizadas na zona rural vivenciam, não faltaram leis para romper com a velha concepção de idealizar o campo como lugar de atraso, e, sobretudo, para propiciar aos moradores do mesmo uma educação que respeite sua cultura, sua identidade. A Lei de Diretrizes e Bases da Educação Nacional (LDB), de 1996, prevê a valorização da cultura e da identidade dos camponeses e camponesas, assim como as Diretrizes Operacionais para a Educação Básica nas Escolas do Campo, aprovada em 2002. Esta última é fruto de grandes debates acerca da educação das áreas rurais, encabeçada principalmente por movimentos de luta pela terra. (REIS, 2004)

As Diretrizes Operacionais para a Educação Básica nas Escolas do Campo indicam a necessidade de projetos pedagógicos nos diversos sistemas de ensino na perspectiva da cidadania, que atendam as diferenças culturais e regionais e a política de igualdade e inclusão. Os artigos 4, 5 e 6 sugerem que as escolas do campo devem incluir em seus Projeto Político Pedagógico (PPP) a diversidade do campo em todos os seus aspectos: sociais, culturais, políticos, econômicos, de gênero, geração e etnia. 
Martins (2005) ressalta que há resistência no âmbito da escola, na qual o conteúdo curricular ainda não é trabalhado no contexto da cultura do campo e que essa resistência em se reformular a educação ofertada nas escolas no campo perpassa pela cultura do professor, sugerindo que o ensino propiciado pelas escolas do campo deveria ser mais flexível e culturalmente adaptado. Segundo esse teórico, a educação básica na cidade é quase que apenas projeção da ideologia de classe média do educador. 0 mesmo acontece no campo. Prevalece, ainda, em grande parte, a concepção de que o educador não precisa ser educado ou reeducado para exercer sua atividade docente.

0 modelo de educação vigente nas zonas rurais tem sido, em termos gerais, descontextualizado. Contudo, segundo Martins (2005), as questões que envolvem a educação do campo são mais complexas do que na cidade, são questões que necessitam ser dialogadas, repensadas, para se compreender que o campo não é sinônimo de passado, o campo é contemporâneo, porém, singular e precisa ser respeitado o direito de ser diferente.

\section{RESULTADOS E DISCUSSÃO}

\section{O COLÉGIO ESTADUAL DO CAMPO VINTE E CINCO DE JULHO - EXTENSÃO ASSENTAMENTO 40/45: ESTRUTURA FÍSICA E PERFIL DOS PROFESSORES}

A importância histórica do Assentamento 40/45 foi fundamental para a definição do local de estudo de caso da pesquisa, o Colégio Estadual Vinte e Cinco de Julho - Extensão Assentamento 40/45. 0 assentamento tem sua origem ainda nos anos de 1980, sendo considerado o assentamento mais antigo da região Nordeste e, por essa razão, torna-se uma referência para o MST e para aqueles que estudam a história e a dinâmica desse movimento social.

Em 5 de setembro de 1987 tem início a ocupação de terras que vai originar o Assentamento 40/45, em uma área de 5.100 hectares localizada no município de Alcobaça - Ba, denominada 4.045. No momento da ocupação a terra já se encontrava desapropriada pelo Decreto n.o 93.024, de 15 de março de 1987 e a emissão de posse foi concedida em 2 de junho de 1987, conforme portaria 483 da Presidência da República. (ARAÚJO, 2007)

Logo após a ocupação da terra os camponeses e camponesas iniciam a fase de estruturação do assentamento e, consequentemente, fez-se necessário fornecer educação escolar para os camponeses e seus filhos e nesse contexto tem início a Escola Municipal Elói Ferreira da Silva, escola de ensino fundamental I e II. Somente no ano de 2008, após várias reivindicações dos assentados, é que se instala no assentamento uma escola de ensino médio.

A princípio, a recém constituída escola era uma extensão do Colégio Estadual Eraldo Tinoco, localizada da cidade de Alcobaça. Em 2011, deixa de ser uma extensão, nascendo assim o Colégio Estadual do Campo Karl Marx. Entretanto, em decorrência da ausência de um gestor e a redução do números de alunos a escola é extinta em abril de 2020 e novamente passa a ser uma extensão, porém, desta vez, de uma escola do campo, o Colégio Estadual do Campo Vinte e Cinco de Julho, localizado na zona rural do município de Prado $\mathrm{Ba}$, distante 125 quilômetros do Assentamento 40/45.

A extensão do Colégio Vinte e Cinco de Julho localizada no Assentamento 40/45 possui 3 salas de aula com capacidade de acomodação de 40 alunos em cada sala, no entanto, no início ano letivo de 2020 haviam apenas 25 matriculados, todos no turno noturno. Além das salas de aula, a escola possui uma sala de secretaria, dois banheiros, uma cozinha, uma sala de direção e uma sala grande, na qual seria destinada às aulas de informática, entretanto a instituição não possui computadores.

No que diz respeito às TICs percebe-se que além de não contar com computadores, a escola tampouco possui impressora, televisão, som ou projetor de imagens. Somente no atual ano foi instalada rede de internet, porém raramente é disponibilizada aos alunos. A ausência das TICs é apontada pelos professores da unidade de ensino como sendo um fator que contribui negativamente na qualidade das aulas e limita a interação dos educandos e educadores com outras realidades.

O Colégio Estadual do Campo Vinte e Cinco de Julho - Extensão Assentamento 40/45 tem duas funcionárias da área de limpeza, uma secretária autorizada e apenas 3 professores, todos moradores do assentamento e trabalham em Regime Especial de Direito Administrativo (REDA) emergencial, ou seja, são indicados por lideranças do próprio assentamento e contratados pelo estado da Bahia por período de dois anos podendo ter seus contratos estendidos por mais dois anos. 
Os docentes contratados da referida escola lecionam por área de conhecimento. 0 professor para área de Ciências Humanas, 39 anos, é licenciado em Pedagogia e Educação Física, entretanto leciona as disciplinas de Geografia, Sociologia, História e Artes. A professora da área de Ciências Exatas, 24 anos, é licenciada em Matemática, trabalha com as disciplinas de Matemática, Física e Estatísticas e o professor da área de Ciências da Natureza, 42 anos, tecnólogo em Gestão Ambiental e licenciando em Letras com habilitação em Língua Inglesa, leciona as disciplinas de Biologia, Química e Língua Inglesa.

Em decorrência do vencimento do contrato da professora da área de Linguagens no final do ano de 2019, a escola se encontrava até agosto de 2020 sem docente de Língua Portuguesa. Com base nas falas dos docentes da escola, a antiga professora de Língua Portuguesa era declaradamente militante do MST, formada em Letras e Pedagogia da Terra, uma iniciativa do MST, que tem por objetivo formar professores dentro da ideologia do movimento. Os professores relataram que a formação em Pedagogia da Terra por parte da professora contribuiu imensamente para uma atuação mais crítica perante os educandos, sempre baseada no respeito ao modo de vida do ser humano do campo, bem como contribuindo para a valorização da identidade cultural dos mesmos.

Percebeu-se na fala dos mesmos, que o fato de serem contratados temporários resulta em algumas consequências negativas no trabalho escolar. Enfatizaram que não se sentem tranquilos no que diz respeito aos seus direitos garantidos, os salários são baixos, não existe progressão na carreira e temem participar de greves ou mobilizações da categoria, pois têm receio de represálias por parte do poder público.

Todos os docentes afirmaram ter participado de algum curso ou encontro promovido pela Secretaria Municipal da Educação de Alcobaça - BA e também pelo MST. O professor da área Ciências Humanas e a professora da área de Ciências Exatas relataram que participaram diversas vezes de cursos e encontros oferecidos pela Prefeitura Municipal de Alcobaça e/ou em parceria com as empresas de celulose da região, entretanto, foram enfáticos em relatar que nunca receberam formação por parte da Secretaria Estadual de Educação da Bahia.

\section{A PROPOSTA PEDAGÓGICA E O CURRÍCULO ESCOLAR}

De acordo com relatos dos professores da extensão do Colégio Estadual do Campo Vinte e Cinco de Julho localizada no Assentamento 40/45 todos os estudantes matriculados na escola são camponeses ou filhos de camponeses e residem no assentamento ou em áreas próximas ao assentamento. Quando questionados se acreditam que a escola é uma referência educacional para o MST, os professores afirmaram que nos últimos anos o assentamento recebeu um número grande de novos moradores provenientes da zona urbana e que, em sua maioria, esses novos moradores não conhecem ou não se identificam com a ideologia do MST e isso impactou muito na educação ofertada pela escola. Todavia, os professores relataram que a escola ainda mantém viva a concepção pedagógica do MST.

Para identificar a essência da concepção pedagógica de uma escola e, consequentemente, de seus professores, deve-se primeiramente entender de que maneira a escola se encontra alicerçada, qual o ponto de partida para os professores desenvolverem suas ações e atingirem suas metas. A base de uma escola é o Projeto Político Pedagógico (PPP), é o que fornece à escola sustentabilidade e autenticidade. 0 PPP é o documento construído coletivamente pelos atores do processo educacional, sejam eles docentes, discentes, pais de discentes, gestores, dentre outros. Os objetivos, as diretrizes e ações a serem desenvolvidos no processo educacional de uma escola devem constar de maneira detalhada no seu Projeto Político Pedagógico. (LIBÂNEO, 2004)

Geralmente uma escola para ser considerada uma escola do campo, e não apenas uma escola no campo, deve conter disciplinas, conteúdos, objetivos ou metas que expressem a valorização ou afirmação da cultura e identidade dos sujeitos que vivem e trabalham no campo. No entanto, os professores e a secretária autorizada afirmaram que a unidade escolar não possui um PPP, dificultando a compreensão de seu objetivo. Para os professores a falta de coordenação pedagógica seria o principal responsável pela não existência do PPP da escola.

Entende-se que a coordenação pedagógica, geralmente, atua como condutora responsável pela articulação, mobilização, organização e harmonização do PPP da escola, entretanto, não é a única responsável, o documento nasce da construção conjunta de toda comunidade escolar, que, por sua vez, deve reconhecer a importância do PPP como a base estrutural da escola. Tendo o mesmo bem definido, ainda havendo rotatividade de alunos, dos professores e funcionários, as estruturas da escola continuam fortes, com seu objetivo e metas bem definidas e a partir dele se planejam as ações. 
Percebeu-se posteriormente em entrevista com o gestor da escola sede localizada no Assentamento Três Irmãos, distante aproximadamente 125 quilômetros do Assentamento 40/45, que apesar dos professores desconhecerem, a escola possui o seu PPP. Segundo o gestor escolar, a extensão do Assentamento 40/45 foi anexada em abril do corrente ano e em decorrência da pandemia do Covid-19 e, consequentemente, o fechamento das escolas impossibilitou a apresentação e debates sobre o PPP e o currículo da escola sede.

Apesar dos professores desconhecerem o PPP e da ausência de coordenação pedagógica, os docentes desenvolvem seus projetos individuais e coletivos. Um dos projetos que envolve, não apenas a escola, mas toda da comunidade, é o "Dia do Agricultor e da Família", que, geralmente, é desenvolvido no mês de julho e tem como objetivo a valorização dos trabalhadores do campo e suas famílias. Segundo os professores, no desenvolvimento dos projetos são realizadas seminários, palestras, apresentações artísticas como dança, música, poesia e produções textuais e confecção de cartazes.

Outra questão relevante no Colégio do Campo Vinte e Cinco de Julho - Extensão Assentamento 40/45 foi a configuração de seu currículo. No entendimento de Machado (2003), o currículo é um instrumento político e técnico responsável por orientar os rumos da escola, configurando-se em um dos pilares da proposta pedagógica das unidades de ensino. É o meio pelo qual definimos os fins sociais e culturais da educação, é a estruturação do caminho que leva à organização de procedimentos e instrumentos para materialização de uma educação contextualizada. Desta maneira implicando em escolhas que irão conduzir a um processo educacional que vise o direcionamento do ser humano e, por conseguinte, do mundo que ser pretende construir.

Ao questionar os educadores a respeito da construção e aplicabilidade do currículo da escola e se este contempla as especificidades da educação do campo, ficou claro que a escola trabalha com um currículo descontextualizado com a realidade dos educandos. A forma que os conteúdos são apresentados na proposta curricular não difere das demais escolas qualificadas como urbanas.

É uma reivindicação antiga a aquisição de material didático específico para a escola do campo que esteja contextualizado com uma proposta pedagógica que contemple uma educação emancipadora, voltada para os educandos do campo visando melhor compreensão da sua realidade, contudo sem deixar de associá-la ao mundo globalizado.

Questionados sobre como falta dos recursos midiáticos impacta na dinâmica pedagógica da escola e quais soluções eles encontravam para minimizar esse problema, o professor da área de Ciências Humanas afirmou que minimizam essas carências com parceria da Escola Municipal Elói Ferreira da Silva, localizada ao lado da extensão do Colégio Vinte e Cinco de Julho.

No entanto, percebe-se que as paredes de uma escola têm muito a nos contar sobre sua identidade, os cartazes colados, as pinturas de imagens, os rabiscos e frases escritas pelos estudantes são relatos de sua história. Segundo Alves (1998), escolas de muros muito altos, geralmente, são um indicativo dos altos índices de criminalidade da comunidade na qual se insere. Muros exageradamente coloridos com imagem alegres e letras divertidas é um indicativo de que ali pode ser uma escola de ensino infantil, ou seja, as paredes, os muros da escola têm muito a nos dizer sobre a essência da escola, da sua identidade de atores.

Ao observar as paredes da extensão do Colégio Estadual do Campo Vinte e Cinco de Julho no Assentamento 40/45 a princípio depara-se com um muro grande, porém não muito alto, pintado de bege, com um portão de ferro. 0 muro na parte externa não possui nenhum tipo de pintura ou pichações, na parte interna uma frase pintada, "Quem o seu inimigo poupa, nas mãos lhe morre" do livro "O Mulato" de Aluísio Azevedo. Segundo os professores a pintura é resultado do projeto de literatura desenvolvido pela professora de Língua Portuguesa em 2018. As paredes da escola, também pintadas de bege, não apresentam rabiscos nem pichações; cartazes, apenas dois, o primeiro com a temática "As meninas na história”, no qual pode-se observar uma foto da ativista Malala Yousafzai ${ }^{28}$, resultado do projeto pedagógico desenvolvido no dia internacional da mulher pelo professor da área de Humanas. 0 segundo cartaz conta a origem do dia da Consciência Negra, também desenvolvido pelo professor de Humanas, porém do ano letivo de 2019.

${ }^{28}$ Malala Yousafzai é uma ativista paquistanesa vencedora do prêmio Nobel em decorrência de sua luta pela defesa dos direitos humanos das mulheres e do acesso à educação. 
Não foram encontrados cartazes ou imagens de mulheres camponesas ou referência aos povos negros do campo como quilombolas. Segundo a secretária autorizada, em decorrência da pandemia do Covid-19 e, consequentemente, o fechamento da escola, aproveitou-se o momento de ausência dos estudantes para fazer limpeza geral nas instalações e com isso foram retirados outros cartazes, inclusive de outros projetos pedagógicos.

\section{CONSIDERAÇÕES FINAIS}

Este artigo vem reforçar que a educação do campo no Brasil, apesar dos avanços na legislação, ainda é tratada com descaso por parte do poder público e órgão competentes. A existência do aparato legal que reforça e respalda a educação ofertada aos povos do campo esbarra na falta de vontade política e nos baixos investimentos que a fragiliza. Percebe-se com esse estudo de caso, que a extensão do Colégio Estadual do Campo Vinte e Cinco de Julho, localizada no Assentamento 40/45, não é diferente de grande parte do país.

São vários os problemas enfrentados pela unidade de ensino que impactam negativamente para a construção de propostas pedagógicas que contribuam para a formação da identidade cultural dos seus educandos e dentre os principais problemas pode-se destacar a falta de apoio pedagógico aos discentes e docentes. A escola não possuiu coordenador pedagógico, tampouco suporte pedagógico por parte do Núcleo Territorial de Educação (NTE), órgão do governo do estado que deveria fornecer suporte às escolas estaduais, cabendo apenas aos docentes a tentativa de organização e harmonização de suas ações dentro da escola.

Outro problema que merece destaque é o currículo, que destoa da realidade dos educandos, não existem disciplinas específicas na programação da escola que tratem das especificidades do campo, percebe-se que o referido currículo não difere do encontrado na maioria das escolas da zona urbana.

\section{REFERÊNCIAS}

[1] ALVES, Nilda. O espaço escolar e suas marcas. Rio de Janeiro: DPA, 1998.

[2] ARAÚJO, Maria Nalva Rodrigues de. As contradições e as possibilidades de construção de uma educação emancipatória no contexto da luta pela terra. Tese de doutorado. UFBA: Salvador, BA, 2007.

[3] ARROYO, Miguel Gonzalez; CALDART, Roseli Salete; MOLINA, Mônica Castagna. Por uma educação do campo. Petrópolis: Vozes, 2004.

[4] BERBAT, Márcio da Costa. FEIJÓ, Gabriela de Carvalho. Diálogos com a Educação do Campo: o livro didático em questão. Revista Brasileira de Educação do Campo, 2016. Disponível em <https://sistemas.uft.edu.br/periodicos/index.php/campo/article/view/2766/11 849> Acesso em: 20 jul. 2020.

[5] BRASIL. Diretrizes Operacionais Para a Educação Básica nas Escolas do Campo. Brasília: CNE/MEC, 2002.

[6] CALDART, Roseli Salete. Por uma educação do campo: traços de uma identidade em construção. In: KOLLING, Edgar Jorge; CERIOLI, Paulo Ricardo, e CALDART, Roseli Salete. (Org). Educação do Campo: Identidade e Políticas Públicas. Brasília, DF: Articulação nacional por uma Educação do Campo, 2002.

[7] FORQUIN, Jean-Claude. Escola e cultura: as bases sociais e epistemológicas do conhecimento escolar. Porto Alegre: Artes Médicas, 1993.

[8] LIBÂNEO, José Carlos. Organização e gestão da escola: teoria e prática. 5. ed. Goiânia: Editora Alternativa, 2004.

[9] MACHADO, Ilma Ferreira. A organização do trabalho pedagógico em uma escola do MST e a perspectiva de formação omnilateral. Tese de Doutorado. Campinas, SP: Faculdade de Educação /UNICAMP, 2003.

[10] MARTINS, José de Souza. Educação rural e o desenraizamento do educador. Revista Espaço Acadêmico, n. 49, jun. 2005.

[11] PENIN, Sônia T. de Sousa. A aula: espaço de conhecimento, lugar de cultura. São Paulo: Papirus, 1994.

[12] REIS, Edmerson dos Santos. Educação do Campo e desenvolvimento rural sustentável:avaliação de uma prática educativa. Juazeiro, Bahia: Gráfica e Editora Franciscana, 2004. SAVIANI, Dermeval. Educação brasileira: estrutura e sistema. São Paulo: Saraiva,1981.

[13] TRIVIÑOS, Augusto Nibaldo S. Introdução à pesquisa em ciências sociais: a pesquisa qualitativa em educação. São Paulo: Editora Atlas S.A, 1987.

[14] VASCONCELlOS, Celso dos Santos. Planejamento: Projeto de ensino aprendizagem e Projeto Político-Pedagógico elementos metodológicos para a elaboração e a realização. 16ª ed. São Paulo: Libertad, 2006 (1995).

[15] WOODWARD, Kathryn. Identidade e diferença: uma introdução teórica e conceitual. In: SILVA, Tomaz Tadeu da. Identidade e diferença: a perspectiva dos estudos culturais. Petrópolis, RJ: Vozes, 2000. 


\section{Capítulo 16}

\section{Pesquisas e o ensino de Ciências: Contribuições e dificuldades no Ensino Fundamental}

\section{Priscilla Cristina Georg \\ Creuzeli Aparecida Soares de Lima \\ Eva Bego \\ Jackson José Pagani}

Resumo: 0 referido estudo, de caráter exploratório e cunho qualitativo, foi baseado na análise de um questionário online respondido por professores do ensino fundamental, com objetivo de averiguar se eles consideram importante o incentivo e uso de pesquisas nas aulas de ciências, observando questões como contribuições e dificuldades da mesma. Os resultados mostram que, apesar das dificuldades relatadas, ficou claro e perceptível, num primeiro momento, que todos acreditam e confirmam que a prática pedagógica com pesquisa e observação é fundamental para aplicação de conteúdos de ciências por unir teoria com a prática, e que os alunos respondem, em sua maioria, com participação e interesse nas atividades, além de motivar e despertar o espírito curioso e criativo, fundamental para a verdadeira aprendizagem e internalização dos conteúdos.

Palavras-chave: Ciências, Pesquisa, Ensino Fundamental. 


\section{INTRODUÇÃO}

A pesquisa e a ciência fazem parte da vida do homem. Ainda na era primitiva, o homem foi aos poucos se desenvolvendo e adquirindo conhecimento através de muitas observações, tentativas, erros, acertos e reflexões. Podemos arriscar dizer que a ciência surgiu assim, de modo quase que instintivo, pois permitiu ao homem sobreviver a condições adversas a partir do que ele tinha disponível.

De acordo com Rampazzo (2005, p.13), a ciência é "o conjunto de conhecimentos precisos e metodicamente ordenados em relação a determinado domínio do saber". E para adquirir esses conhecimentos, foram necessárias pesquisas. Ou seja, ciência e pesquisa andam juntas.

Entretanto, para garantir a qualidade da pesquisa, são necessários métodos a serem seguidos, resultando no método científico. Para Rampazzo (2005), o método científico tem suas especificidades nas diferentes ciências, como por exemplo, nas ciências experimentais, onde o cientista analisa e 'manipula' as coisas, ou nas ciências humanas, onde procura 'entender' as pessoas, com seus comportamentos, culturas, leis, entre outros.

Cientes que pesquisas de qualidade - provenientes de métodos científicos - geram conhecimento científico, gostaríamos de pontuar que especificamente para esse trabalho, não abordaremos esse tipo de pesquisa, a qual exige todo um rigor metodológico a ser seguido. Abordaremos a pesquisa em âmbito escolar, que envolve adquirir conhecimento a partir de estudos, buscas, práticas e reflexões sobre o objeto pesquisado. Assim, o foco está na prática introdutória e investigativa que a mesma tem.

Para melhor esclarecer o significado da palavra pesquisa, consultamos o Dicionário online de Português (DICIO, 2020), o qual traz definições para a palavra:

Reunião de operações ou atividades que visa descobrir novos conhecimentos em vários domínios, principalmente no âmbito científico;/ Ação ou efeito de pesquisar, de buscar mais informações a respeito de algo ou de alguém;/Enquete que busca antecipar o resultado final de uma eleição a partir da opinião dos eleitores: pesquisa eleitoral; /Estudo realizado para aumentar o conhecimento em determinada área do saber; /Ação de investigar de maneira detalhada; investigação; /Exame que se faz em laboratório.

Percebe-se então que nem toda pesquisa é científica. No entanto, até mesmo as pesquisas menos rigorosas do que as científicas precisam de métodos, de procedimentos definidos e orientados para chegar a determinado conhecimento, o que não a torna menos importante.

Dessa forma, com esse trabalho pretende-se averiguar, por intermédio de um questionário online, se professores do ensino fundamental consideram importante o incentivo e uso de pesquisas em sala de aula, observando questões como contribuições e dificuldades.

O trabalho se apresenta em três partes a partir da Introdução: Referencial Teórico, com breves considerações sobre a prática de pesquisas nas escolas e orientações dos PCN de Ciências Naturais e a BNCC (Base Nacional Comum Curricular); Resultados e Discussões, em que se apresentam os resultados, análise e comentários do questionário respondido por professores do Ensino Fundamental e por fim as Considerações Finais, com vistas à valorização do material para formação docente.

\section{REFERENCIAL TEÓRICO}

O ensino de ciências nas escolas, ainda nos dias de hoje, continua enfrentando barreiras que já deveriam ter sido superadas há décadas. Com o advento da modernidade, das tecnologias e da facilidade de informação, poderíamos dizer que o ensino seguiu o mesmo caminho, ou seja, evoluiu. No entanto, o que ainda observa-se são práticas de ensino arcaicas, baseadas em memorização de conteúdo, sem aplicação prática e sem contextualização.

As práticas de ensino tendo pesquisas como base são de fundamental importância para a aquisição de inúmeras características pelas quais buscamos em uma formação de qualidade, como desenvolver o espírito investigativo, criativo, questionador, crítico, analítico e capaz de resolver problemas de diversas ordens.

Alguns autores, como Mckernan (2009), Demo (2007) e Freiberger e Berbel (2010), apontam sobre os mesmos problemas na educação, conforme veremos a seguir: 
Segundo Mckernan (2009, p.142), "existe uma tradição de que os professores de escolas de níveis fundamental e médio ensinam e de que os professores universitários fazem pesquisa". Mas o autor diz que a pesquisa educacional compete também aos professores das escolas, fazendo das escolas não apenas distribuidoras de conhecimento, mas um lugar em que os professores e os alunos possam ser produtores de conhecimento.

Freiberger e Berbel (2010) defendem que o desafio de educar por meio de pesquisa justifica-se pela necessidade de uma educação que contemple teoria e prática, sendo esse um meio de promover, no sujeito, aprendizados que possibilitem o desenvolvimento da autonomia intelectual e da consciência crítica, estimulando questionamentos, elaboração de perguntas pelo aluno e a instrumentalização pela pesquisa.

Segundo Demo (2007, p. 7), “onde não aparece o questionamento reconstrutivo, não emerge a propriedade educativa escolar". Para o autor, a educação e a pesquisa têm trajetos coincidentes, pois ambas se postam contra a ignorância, valorizam o questionamento, se dedicam ao processo reconstrutivo, confluem entre a teoria e a prática, se opõem à condição de objeto e de procedimentos manipulativos e condenam a cópia.

Apesar das práticas mais tradicionalistas estarem muito arraigadas na forma de atuação do professor, a mesma não é prescrita nos documentos oficiais de educação de nosso país, como Lei de Diretrizes e Bases da Educação - LDB no 9.394/96, Parâmetros Curriculares Nacionais - PCN (1997), e a Base Nacional Comum Curricular - BNCC (2018). Sendo assim, não há motivos para perpetuar tal prática.

Com base nesses documentos, citamos primeiro a LDB no 9.394/96, que traz, em seu Art. 4ํㅜ, que o dever do Estado com a educação escolar pública será efetivado mediante a garantia de vários itens. Dentre eles, destacamos o V item, que garante "acesso aos níveis mais elevados do ensino, da pesquisa e da criação artística, segundo a capacidade de cada um" (BRASIL, 1996).

De acordo com os Parâmetros Curriculares Nacionais (PCN) de Ciências Naturais (BRASIL, 1997, p. 27), o estudo não deve ser baseado somente em livros. Pelo contrário, deve haver interação com os fenômenos naturais ou tecnológicos, oferecendo diferentes métodos para obter informações, como observação, experimentação, jogos, fontes textuais diversas, permitindo comparar informações, analisar e despertar o interesse pelo conteúdo.

Por fim, a BNCC (2018), que é o documento oficial de educação mais recente, nos traz listada como a segunda, dentre as dez Competências Gerais da Educação Básica, uma importante referência ao assunto abordado, que é a competência de:

Exercitar a curiosidade intelectual e recorrer à abordagem própria das ciências, incluindo a investigação, a reflexão, a análise crítica, a imaginação e a criatividade, para investigar causas, elaborar e testar hipóteses, formular e resolver problemas e criar soluções (inclusive tecnológicas) com base nos conhecimentos das diferentes áreas.(BRASIL, 2018, p. 9)

Dessa forma, a orientação dentro da área de Ciências da Natureza da BNCC é de que:

0 processo investigativo deve ser entendido como elemento central na formação dos estudantes, em um sentido mais amplo, e cujo desenvolvimento deve ser atrelado a situações didáticas planejadas ao longo de toda a educação básica, de modo a possibilitar aos alunos revisitar de forma reflexiva seus conhecimentos e sua compreensão acerca do mundo em que vivem (BRASIL, 2018, p.322).

Assim, tendo o respaldo dos documentos oficiais de Educação e das referências supracitadas, que trazem a pesquisa como forma de conhecimento, seguimos para o objetivo proposto, que foi averiguar, por intermédio de um questionário online destinado a professores do ensino fundamental, se estes consideram importante o incentivo e uso de pesquisas em ciências, observando questões como contribuições e dificuldades da mesma.

\section{METODOLOGIA}

Este estudo, de caráter exploratório, teve o intuito de averiguar, em um pequeno número de professores, algumas questões relacionadas ao assunto "pesquisa" no universo escolar. Segundo Gil (2008, p.27), as 
"pesquisas exploratórias são desenvolvidas com o objetivo de proporcionar visão geral, de tipo aproximativo, acerca de determinado fato". Assim, as respostas fornecidas servem como um direcionamento para o referido estudo, e para pesquisas posteriores.

Para isso, um questionário foi encaminhado a oito (8) professores do Ensino Fundamental da cidade de Maringá, com os seguintes objetivos:

- Identificar se a pesquisa pode ser utilizada como motivador de participação e se contribui para o processo de aprendizagem em ciências;

- Demonstrar a importância e principais contribuições dessa prática no ensino fundamental.

- Apontar dificuldades na sua utilização.

O questionário, encaminhado aos professores por email (via formulário Google), foi formulado com perguntas ora objetivas, ora descritivas. Dessa forma, foi possível realizar análises qualitativas, que visam à compreensão de comportamentos, atitudes e principalmente, as interpretações dos sujeitos sobre uma determinada realidade (SOUZA, 2005), além de permitir a descrição e análise do conteúdo da pesquisa. Utilizou-se também como ferramenta a estatística descritiva, que representam a frequência de cada resposta entre os entrevistados, exatamente como bem propõe Gil (2008).

Os professores participantes foram escolhidos com base na rede de relacionamento dos autores. Os nomes foram omitidos por questão de preservação da identidade de cada um. No entanto, para manter a individualidade, denominamos cada participação com uma letra sequencial do alfabeto, de acordo com a ordem em que eram devolvidos com as respostas preenchidas. Assim, podemos atribuir a devida autoria a cada um.

Apresentamos a seguir os resultados obtidos e discussão.

\section{RESULTADOS E DISCUSSÃO}

Inicia-se apresentando um quadro (QUADRO 1) demonstrativo dos anos escolares de atuação de cada professor seguido do tipo de instituição ao qual pertencem:

Quadro 1- Anos de atuação no Ensino Fundamental e tipo de instituição:
\begin{tabular}{|c|c|c|c|} 
PROFESSOR & SEXO & ANOS DE ATUAÇÃO & INSTITUIÇÃO \\
\hline A & Masculino & $6^{\circ}, 7^{\circ}, 8^{\circ}$ anos & Pública \\
\hline B & Masculino & $4^{\circ}$ ano & Pública \\
\hline C & Feminino & $2^{\circ}$ e $4^{\circ}$ ano & Pública \\
\hline D & Feminino & $3^{\circ}$ ano & Pública \\
\hline E & Feminino & $1^{\circ}, 2^{\circ}$ e $3^{\circ}$ ano & Pública \\
\hline F & Feminino & $2^{\circ}$ e $3^{\circ}$ ano & Pública \\
\hline G & Feminino & $2^{\circ}$ ano & Privada \\
\hline H & Feminino & $3^{\circ}$ ano & Pública \\
\hline
\end{tabular}

Fonte: os autores

0 questionário foi respondido por oito (8) professores do ensino fundamental, contemplando perfis masculino e feminino, fundamental 1 e 2 e rede pública e privada.

Quando perguntados se incentivavam a prática de pesquisa em suas aulas, a resposta foi unânime: sim. Desses, 62,5\% incentivam pesquisas teórico-práticas, 25,0\% incentivam pesquisas teóricas e 12,5\% incentivam pesquisas práticas.

Sobre a frequência em que incentivam tal prática 75,0\% responderam "às vezes" e 25,0\% responderam "sempre". Isso mostra que, apesar das pesquisas serem importantes, elas não são o único meio de se trabalhar conteúdo escolares. Há outras vias que podem e devem ser exploradas pelo professor.

No quesito motivação, observamos que 75,0\% acreditam que as pesquisas motivam muito a participação dos alunos. No entanto, $25,0 \%$ disseram que motivam "um pouco". O motivo para isso talvez esteja relacionado a algumas dificuldades encontradas pelos professores na hora de colocar em prática as pesquisas, conforme será relatado posteriormente. 
Na sequência, perguntamos se eles acreditam que as pesquisas contribuem de alguma forma para a aprendizagem dos alunos (contribui como efetiva fonte de conhecimento?). Os resultados foram: 87,5\% responderam que "sim, muito". Apenas 12,5\% responderam que "sim, um pouco". Nesse caso, a resposta pode estar correlacionada ao fator idade dos alunos, visto ter sido a resposta da professora E, única a ter alunos no primeiro ano.

Da mesma forma, quando questionados quanto à viabilidade do uso das pesquisas no Ensino Fundamental, apenas uma respondeu que é viável "às vezes, e só é viável para os maiores". Neste caso, a resposta foi da professora E, a mesma que relatou que as pesquisas contribuem "um pouco" na participação e aprendizagem.

O professor A disse que "além de viáveis, as pesquisas são fundamentais para o desenvolvimento cognitivo dos alunos, além de contribuir para os três tipos de aprendizagem: conceituais, procedimentais e atitudinais". O professor B ressaltou que "é viável, pois não são necessários materiais específicos e caros". A professora D disse ser "um meio de incentivar o aluno a ser pesquisador", assim como a professora $F$, que disse ser "uma oportunidade de desenvolver o gosto pela ciência desde criança". A professora G não comentou sobre o assunto, e a professora $\mathrm{H}$ disse que são viáveis e pode ser iniciada desde a Educação Infantil.

Esses relatos nos remetem aos autores citados anteriormente, como Mckernan (2009), Demo (2007) e Freiberger e Berbel (2010), os quais fazem referências positivas ao uso das pesquisas nas escolas, proporcionando, entre outros benefícios, a produção de conhecimento unindo teoria com a prática.

Prosseguindo com o questionário, pedimos que cada professor descrevesse sua opinião sobre o que é pesquisa, como a insere em sala de aula, além das contribuições e dificuldades encontradas na sua aplicação.

O professor A disse que as pesquisas são fundamentais, e que trabalha tanto com pesquisas bibliográficas como com demonstrações práticas e, preferencialmente em pequenos grupos, estimulando a discussão entre os participantes. Quanto às contribuições, o mesmo relatou que "essas práticas podem contribuir muito mais que a aprendizagem conceitual, elas podem gerar a aprendizagem procedimental e aprendizagem atitudinal".

Já no quesito dificuldades encontradas, o professor A relatou que "no primeiro momento é a resistência dos próprios alunos, que muitas vezes são acostumados com aulas mais teóricas e menos práticas (tradicionais), daí gera muita confusão na organização da turma, das atividades realizadas em grupos e das pesquisas que os alunos têm que antecipar e construir algumas vezes sozinhos. A segunda dificuldade é o rompimento das nossas práticas docentes, pois por mais que cuido dos meus passos metodológicos em sala, por muitas vezes ainda me apego as atividades tradicionais, ou seja, é uma resistência epistemológica e não metodológica. Por último, a estrutura das instituições, que muitas vezes não tem condições físicas e humanas para dar suporte às práticas que envolvem laboratório ou algo assim".

O professor B conceitua pesquisa como "meio de proporcionar aos alunos e alunas a possibilidade de descobrir (de forma orientada) questões pertinentes ao nosso dia-a-dia. Pesquisar é contemplar as manifestações naturais e humanas e estabelecer relação com os conteúdos historicamente acumulados pela humanidade".

De acordo com seu relato, o professor B insere pesquisas em aula "lançando desafios, que os façam refletir sobre os fenômenos. Por exemplo, a necessidade da água para os seres vivos. Todas as vezes que se planta feijão, coloca-se água em todos os copinhos. Para entender essa necessidade, basta colocar copos com água e sem água. 0 conceito da necessidade da água será construído por meio da observação."

Encontramos a mesma linha de raciocínio em Oliveira (2006) e Roitman (2007). Para Oliveira (2006, pág.35), "aprendizado sem relação com a realidade não se concretiza, pois, não oferece significado e, portanto, não desperta o interesse do aluno". Roitman (2007, p. 13) cita que "uma sala de ensino de ciências não é simplesmente um lugar onde os estudantes são alfabetizados nos principais conceitos e terminologia. Na realidade deve ser um ambiente onde o estudante aprende a formular perguntas, testar hipóteses e articular ideias com a informação."

Sobre as contribuições e dificuldades encontradas, o professor B relatou que as pesquisas contribuem para que haja mais "interesse por entender como ocorrem os fenômenos. Construção do conhecimento por meio de experiências e mediados pelo conteúdo e pelo professor". As dificuldades relatadas por ele são "falta de recursos físicos e tecnológicos. Desmotivação por parte de alguns alunos/alunas. Falta de espaços adequados". 
A professora C conceitua pesquisa como "uma maneira de aprendizagem significativa em busca do conhecimento científico." Sua forma de inserir as pesquisas em sala de aula são por meio de "estudo do vocabulário, entendimento da gramática entre outras". Em relação às contribuições, disse ser "a sistematização da aprendizagem de maneira significativa". E as dificuldades são o "planejamento já vir pronto da secretaria" (de Educação do Município).

Para a professora D, pesquisa para "é fazer uma investigação". Suas pesquisas são inseridas por meio da Internet, tendo como contribuição "os alunos demonstrarem mais interesse pelo estudo". Como dificuldade, citou a tecnologia (não explicando o motivo).

A professora E disse que "pesquisa é ampliação de conhecimentos, mas para o ensino fundamental só funciona a partir do $3^{\circ}$ ano, que a criança já consegue fazer sozinha”. Segundo ela, as pesquisas só são utilizadas "quando precisamos aprender algo diferente". Como ponto positivo, citou "a ampliação dos conhecimentos", e como negativo, que "nem todos os alunos têm acesso a internet, computadores ou outros materiais".

Para a professora F, pesquisa é "ter uma curiosidade, um objeto de estudo". A mesma insere a pesquisa "a partir de um tema, passando para uma pergunta geradora da pesquisa e a prática como fim; na sequência retorno à pergunta para analisarmos os resultados".

O método utilizado por essa professora condiz com as falas de Freire (1987), que indica a problematização e o diálogo como meio para que as condições da aprendizagem transformem os educandos e educadores em sujeitos da própria aprendizagem.

De acordo com a professora $\mathrm{F}$, as contribuições da pesquisa são "a aprendizagem dos alunos de forma agradável e envolvente sobre o conhecimento", e as dificuldades são as questões "burocráticas e de materiais, mas as crianças amam e se envolvem muito". A mesma também relatou que gosta muito de aulas práticas, e que gostaria de poder fazer mais. Entretanto, a falta de materiais, quantidade de alunos (grande) e falta de uma sala específica atrapalham. Também relatou que alguns professores temem por medo de perder a disciplina da sala, mas ganha-se muito na aprendizagem.

A professora G, única da rede particular, conceitua pesquisas como "a descoberta de novos conhecimentos científicos". A professora insere as pesquisas por meio de pesquisa em dicionários, família e internet. Como contraponto, citou a falta de tempo para ensinar os alunos, e como contribuição citou a ampliação do conhecimento.

Por fim, temos a professora H. Para ela, pesquisa "é a descoberta de novas possibilidades. É avanço". As pesquisas são inseridas "abordando um determinado tema, trabalhando em sala, separando em pequenos grupos e solicitando aos mesmos que pesquisem outras possibilidades". Como contribuição, relatou que a pesquisa "leva o aluno a pensar", e como contraponto, citou que a mesma pode se esbarrar em "falta de recursos".

Podemos perceber na maioria dos relatos que os professores se preocupam em associar a teoria com a prática, aparentando estarem alinhados aos documentos oficiais de educação.

Compreendemos que temos entre o fundamental 1 e 2 uma diferença de idade considerável, no entanto, acredita-se que a pesquisa possa ser realizada em todas as idades, desde que atenda às necessidades educacionais dos alunos e seus níveis cognitivos.

Nesse sentido, é oportuno citar Oliveira e Oliveira (2019), cuja publicação relacionando neurociência cognitiva e o ensino de ciências nos faz lembrar que, devido à neuroplasticidade cerebral, quanto mais estímulos externos são oferecidos, mais conexões cerebrais são ativadas, potencializando as respostas cognitivas, ou seja, a aprendizagem.

Vale ressaltar que o PCN de Ciências Naturais nos lembra que o conhecimento científico é fundamental, mas não suficiente. "É essencial considerar o desenvolvimento cognitivo dos estudantes, relacionado à suas experiências, sua idade, sua identidade cultural e social, e os diferentes significados e valores que as Ciências Naturais podem ter para eles, para que a aprendizagem seja significativa” (BRASIL, 1997).

Além disso, no próprio PCN (BRASIL, 1997) temos os ciclos (iniciais e finais), os quais consideram as fases de desenvolvimento e suas especificidades, que devem ser respeitadas. Assim, independentemente da idade de educando, devemos dar atenção especial à variação de estímulos, uma vez que nem todos aprendem da mesma maneira.

Nesse sentido, a pesquisa no âmbito escolar sai na frente, pois possibilita um leque de caminhos a serem seguidos, unindo a teoria com a vivência da prática, além de motivar e despertar o espírito curioso e 
criativo das crianças/adolescentes, fundamental para a verdadeira aprendizagem e internalização dos conteúdos.

\section{CONSIDERAÇÕES FINAIS}

A partir das respostas e contribuições dadas pelos participantes no questionário aplicado, podemos concluir o referido estudo, atendendo ao objetivo proposto, que foi averiguar se eles consideram importante o incentivo e uso de pesquisas, observando questões como: contribuições e dificuldades da mesma, destacando os seguintes aspectos conclusivos.

Ficou claro, num primeiro momento, que todos acreditam que a prática pedagógica com pesquisa e observação é fundamental para aplicação de conteúdos de ciências e que as crianças respondem, em sua maioria, com participação e interesse nas atividades, além de contribuir para a verdadeira aprendizagem e internalização dos conteúdos.

Apesar das dificuldades relatadas, como falta de estrutura, tecnologia e materiais adequados, número grande de alunos em sala, resistência de alunos e professores acostumados com práticas tradicionais, burocracias e falta de tempo (na grade curricular), temos como positividade da pesquisa que o conhecimento sendo aplicado com a definição do material e recursos disponíveis, a exposição ao aluno à prática e aos questionamentos que são gerados, farão toda diferença na aprendizagem. A característica da turma, os aspectos sociais e emocionais complementam como se desenvolverá o ensino, buscando a sua excelência.

Gostaríamos de deixar claro que o número de professores pesquisados foi pequeno, mas serviu como referência para esse primeiro estudo sobre as pesquisas em sala de aula. Notamos que, dentre outras coisas, o incentivo e prática das pesquisas variam de acordo com os perfis dos profissionais. Uns mais ativos, outros mais passivos.

Como sugestão para posterior estudo, pode-se traçar um comparativo entre professores de todos os anos do ensino fundamental, para identificar com maior clareza se o fator idade é ou não determinante para a realização de pesquisas, ou mesmo como aplicá-las nos anos iniciais. Pode-se também realizar um estudo comparativo entre escolas públicas e privadas. Ou até mesmo, como sugestão de um dos professores, fazer um estudo sobre como os alunos percebem ou não a importância das pesquisas no seu processo de aprendizagem.

Por fim, fica a gratidão aos participantes e à oportunidade de realizar essa pesquisa, que possibilitou a aquisição de novos conhecimentos e horizontes para nossa atuação como docentes.

\section{REFERÊNCIAS}

[1] BRASIL. Secretaria de Educação Fundamental. Parâmetros Curriculares Nacionais: Ciências Naturais. Brasília: MEC/SEF, 1998. Disponível em: http://portal.mec.gov.br/seb/arquivos/pdf/livro04.pdf. Acesso em: 06 abr. 2020 .

[2] BRASIL. Lei de Diretrizes e Bases da Educação Nacional (LDB). Lei no 9.394/96, de 20 de dezembro de 1996. Disponível em: http://www.planalto.gov.br/ccivil_03/leis/19394.htm. Acesso em: 10 mai. 2020.

[3] BRASIL. Ministério da Educação. Base Nacional Comum Curricular: educação é a base. Secretaria de Educação Básica. - Brasília: MEC, SEB, 2018. Disponível em:

http://basenacionalcomum.mec.gov.br/images/BNCC_EI_EF_110518_versaofinal_site.pdf. Acesso em: fev. 2020.

[4] DEMO, P. Educar pela pesquisa. 8. ed. Campinas, SP: Autores Associados, 2007.

[5] FREIBERGER, R. M., BERBEL, N. A. N. A importância da pesquisa como princípio educativo na atuação pedagógica de professores de educação infantil e ensino fundamental. Cadernos de Educação, Pelotas, v.37, p.207-245, 2010. Disponível em: https://periodicos.ufpel.edu.br/ojs2/index.php/caduc/article/view/1587. Acesso em: fev. 2020.

[6] FREIRE, P.. Pedagogia do Oprimido. Rio de Janeiro: Paz e Terra, 1987.

[7] GIL, A. C. Métodos e técnicas de pesquisa social. 6. ed. São Paulo: Atlas, 2008.

[8] MCKERNAN, J.. Currículo e imaginação: Teoria do processo, pedagogia e pesquisa-ação. (Tradução Gisele Klein). Porto Alegre: Artmed, 2009. 286p.

[9] OLIVEIRA, A. L. Educação Ambiental: Concepções e Práticas de Professores de Ciências do Ensino Fundamental. 2006. Dissertação (Mestrado em Educação para a Ciência e o Ensino de Matemática).Universidade 
Estadual de Maringá. Disponível em: http://repositorio.uem.br:8080/jspui/bitstream/1/4442/1/000153758.pdf. Acesso em: Mar. 2020

[10] OLIVEIRA, C. M.; OLIVEIRA, A. L. Dissertações e Teses Encontradas no Banco da Capes (2000 - 2017) Correlacionadas à Neurociência Cognitiva e o Ensino de Ciências. Revista Ciências \& Ideias. ISSN: 2176-1477. v. 10, n. 1, Jan./Abr. 2019. Disponível em: https://revistascientificas.ifrj.edu.br/revista/index.php/reci/article/view/772. Acesso em: Mar. 2020

[11] PESQUISA. In: DICIO. Dicionário Online de Português. Porto: 7Graus, 2020. Disponível em: https://www.dicio.com.br/pesquisa/. Acesso em: 20 mar. 2020.

[12] RAMPAZZO, L. Metodologia Científica: para alunos dos cursos de graduação e pós-graduação. 3o Ed. São $\begin{array}{lllll}\text { Paulo: } & \text { Ed. } & \text { Loyola, } & \text { Disponível } & \text { em: }\end{array}$ https://books.google.com.br/books?id=rwyufjs_DhAC\&printsec=frontcover\&dq=metodologia+cientifica\&hl=ptBR\&sa =X\&ved=0ahUKEwjBvaSc7vDXAhVIl5AKHcezCkQQ6AEIJzAA\#v=onepage\&q=metodologia\%20cientifica\&f=false. Acesso em: mar. 2020.

[13] ROITMAN, I. Educação científica: quando mais cedo melhor. Brasília: RITLA, 2007. Disponível em: http://www.dominiopublico.gov.br/download/texto/rl000001.pdf. Acesso em: mar. 2020.

[14] SOUZA, V. L. T. Escola e construção de valores: desafios à formação do aluno e do professor. São Paulo: Loyola, 2005. 


\section{Capitulo 17}

Conhecendo aranha marrom e loxoscelismo: Prevenção, características dos acidentes e sintomas do envenenamento, um trabalho realizado com alunos do quarto ano do Ensino Fundamental

\section{Mariana Luiza Claudino Mataruna}

\section{Guilherme Ferreira dos Santos}

Silvio Sanches Veiga

Ana Carolina Martins Wille

Cristina Lúcia Sant'Ana Costa Ayub

Resumo: As aranhas designadas por aranha-marrom pertencem ao gênero Loxosceles e são bastante encontradas nas regiões sudeste e sul do Brasil incluindo a cidade de Ponta Grossa-PR. Eventos patológicos e clínicos desenvolvidos após as picadas por estas aranhas são denominados de loxoscelismo. Nos casos menos graves geralmente pode ocorrer o quadro cutâneo ou dermonecrótico e nos mais graves o quadro cutâneovisceral ou sistêmico que atinge de $0,7 \%$ a $27 \%$ dos casos. Os sintomas deste quadro são muito graves e incluem hematúria, hemoglobinúria, icterícia, coagulação intravascular disseminada e falência renal aguda que é a maior responsável pelos casos de óbito no loxoscelismo. Diante da ocorrência destes animais na cidade de Ponta Grossa e da gravidade dos sintomas, a disseminação de informações sobre o tema entre as pessoas da comunidade é muito importante sobretudo em crianças em idade escolar. Devido ao exposto acima foi realizado um trabalho com alunos do quarto ano de uma escola municipal de Ponta Grossa, PR. Os resultados observados mostraram que o trabalho realizado foi de grande relevância tanto para os estudantes participantes que efetivaram seu próprio conhecimento quanto para as comunidades onde vivem pois se tornaram disseminadores de informações corretas e atualizadas sobre o tema.

Palavras-chave: aranha-marrom, loxoscelismo, dermonecrose, recursos didáticos 


\section{NOME DO PROGRAMA OU PROJETO}

Laboratório de Recursos Didáticos em Ciências Morfológicas 2a Edição

\subsection{PÚBLICO-ALVO}

Alunos do quarto ano de uma escola municipal de Ponta Grossa, Paraná (PR).

\subsection{MUNICÍPIOS ATINGIDOS}

Ponta Grossa, PR.

\subsection{LOCAL DE EXECUÇÃO}

Universidade Estadual de Ponta Grossa, Setor de Ciências Biológicas e da Saúde, Departamento de Biologia Estrutural, Molecular e Genética, Laboratório M69. Escola Municipal Professora Armida Frare Gracia, Ponta Grossa, PR.

\section{JUSTIFICATIVA}

A extensão universitária é processo educativo, cultural e científico que articula o ensino e a pesquisa de forma indissociável e viabiliza a relação transformadora entre universidade e sociedade (SARAIVA, J. L., 2007). Diante deste conceito buscou-se a interação de acadêmicos da Universidade Estadual de Ponta Grossa com estudantes da Escola Municipal Professora Armida Frare Gracia, Ponta Grossa, PR com a finalidade de levar esclarecimentos e promover a construção do saber aos estudantes participantes do trabalho dentro do tema: aranhas-marrom e loxoscelismo.

Sabe-se da relevância deste tema, visto que, a região é endêmica para a ocorrência de aranhas L. intermedia e que estas estão envolvidas em inúmeros casos de acidentes com humanos que desencadeiam nos acidentados eventos patológicos e clínicos denominados loxoscelismo.

O loxocelismo pode gerar dois tipos de quadros clínicos distintos: o quadro cutâneo ou dermonecrótico em que ocorre uma reação inflamatória intensa no local da picada e após vários dias forma-se uma área de necrose com uma lesão circulada por halo vermelho, com uma zona pálida central, chamada de placa marmórea (FUTRELL, 1992) e o quadro cutâneo-visceral ou sistêmico no qual podem ser observados alterações no quadro hematológico, podendo chegar à coagulação intravascular disseminada, agregação plaquetária e anemia hemolítica. Em pacientes que foram a óbito pode ser ressaltado alterações degenerativas nos parênquimas de vários órgãos, entre elas se destacam edema, congestão, hemorragia e erosões da mucosa digestiva, além de lesões renais e insuficiência renal aguda (IRA) (da SILVA, et al., 2004 GREMSKI et al., 2020).

Os acidentes com humanos normalmente ocorrem devido a estas aranhas terem adquirido hábitos intradomiciliares e estarem em contato muito próximo de humanos e animais domésticos, se abrigando em camas, roupas, frestas, cantos de paredes, atrás de armários ou quadros.

Diante disto, foram levados pelos acadêmicos da Universidade Estadual de Ponta Grossa aos estudantes do quarto ano do ensino fundamental da escola municipal mencionada anteriormente, informações sobre como conhecer e identificar aranhas do gênero Loxosceles, principais locais onde elas podem ser encontradas, como acontece a picada, reconhecer as características da picada e como prevenir-se de acidentes. Tais conhecimentos visaram tanto que efetivassem seu próprio conhecimento quanto para se tornarem disseminadores de informações corretas e atualizadas sobre o tema para a comunidade em que vivem. 


\section{OBJETIVOS}

\subsection{GERAL}

Levar informações corretas e atualizadas a respeito de aranhas-marrom e loxoscelismo para estudantes do ensino fundamental (quarto ano) para que eles adquiram conhecimentos sobre o tema, bem como, façam a translocação do que aprenderam para as pessoas com quem convivem tornando-se disseminadores do conhecimento.

\subsection{ESPECÍFICOS}

Levar conhecimentos científicos atualizados para a comunidade escolar (alunos do quarto ano) sobre aranha-marrom e loxoscelismo;

$>\quad$ Proporcionar aos estudantes participantes do projeto conhecimentos para que sejam capazes de diferenciar aranhas do gênero Loxoceles de outras;

$>\quad$ Tornar os estudantes capazes de reconhecer possíveis sintomas do envenenamento por aranhasmarrom;

> Tornar os estudantes capazes de estimar os locais onde pode ser possível encontrar as aranhasmarrom e preveni-los de acidentes;

Tornar os estudantes disseminadores de informações corretas sobre o tema para que se tornem disseminadores do que aprenderam para a comunidade em que estão inseridos;

\section{METODOLOGIA}

- Visita a Escola Municipal Professora Armida Frare Gracia, Ponta Grossa, PR para apresentar aos gestores e professores a proposta do trabalho e solicitar sua autorização junto a escola e aos seus estudantes;

- Após obtida a autorização, primeiro contato com as duas turmas do quarto ano matutino para diagnosticar o conhecimento prévio dos estudantes sobre o tema;

- Realização do evento com oficinas práticas onde os estudantes aprenderam de forma lúdica o tema, além disso, fizeram maquetes sobre aranhas e realizaram desenhos, pinturas e caça-palavras para fixação do conteúdo e verificação da aprendizagem (Figura 1);

- Encontro com a equipe executora do trabalho para verificação dos resultados obtidos;

\section{RESULTADOS}

Os alunos ficaram muito entusiasmados com o trabalho executado, a cada instante traziam relatos da experiência que tiveram com aranhas nas suas casas e na escola. Ao final sabiam distinguir os tipos das aranhas-marrom, bem como, sabiam elencar os possíveis locais de sua ocorrência, o que é de extrema importância para a prevenção de acidentes.

Também foi possível verificar que eram capazes de reconhecer características de lesões dermonecróticas causadas pelo envenenamento por aranhas-marrom e principalmente que as consequências do envenenamento poderiam ser fatais.

Além disso, os estudantes falavam que iriam transmitir aos familiares o que aprenderam na oficina (Figura 1) especialmente as maneiras de prevenir os acidentes demonstrando preocupação com os familiares.

Desta forma, pode-se dizer que os objetivos esperados foram alcançados uma vez que os alunos além de adquirirem seus próprios conhecimentos preocuparam-se em transmitir aos familiares atuando como disseminadores de informações para a comunidade. 
Figura 1: Oficina sobre aranha-marrom e loxoscelismo
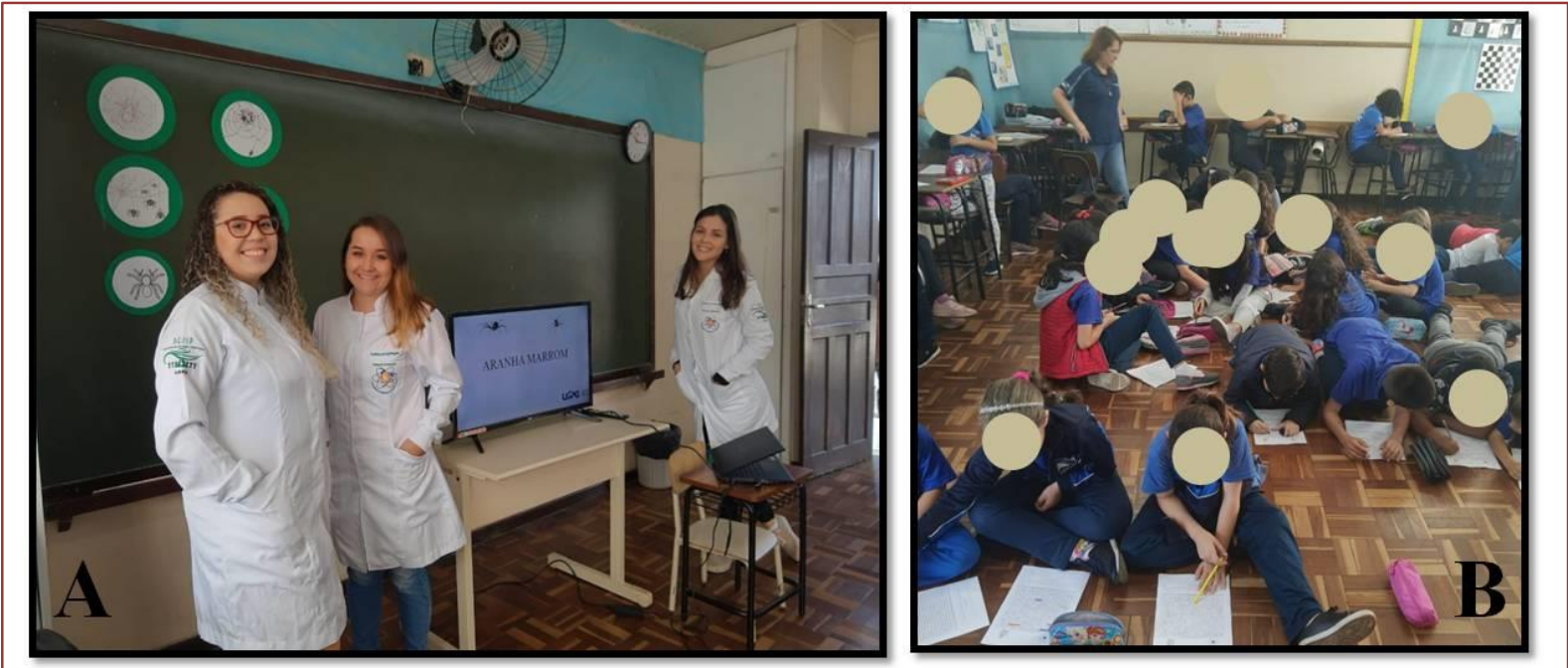

Figura 1: Em A, as acadêmicas da Universidade Estadual de Ponta Grossa apresentando o trabalho sobre aranhasmarrom e loxoscelismo, em B os estudantes da Escola Municipal Professora Armida Frare Gracia, Ponta Grossa, PR realizando as atividades da oficina.

\section{CONSIDERAÇÕES FINAIS}

A realização deste trabalho foi muito importante, pois proporcionou aos acadêmicos da Universidade Estadual de Ponta Grossa um maior contato com a comunidade quanto aos estudantes dos quarto anos matutino da Escola Municipal Professora Armida Frare Gracia, Ponta Grossa, PR trazendo informações mais atualizadas sobre aranhas-marrom e loxoscelismo tanto para seu próprio conhecimento quanto como para serem disseminadores de informações corretas e atualizadas sobre o tema para a comunidade em que estão inseridos.

\section{APOIO}

À PROEX da Universidade Estadual de Ponta Grossa por promover a realização deste trabalho, aos professores e demais envolvidos da Escola Municipal Professora Armida Frare Gracia por proporcionar as condições para a realização do trabalho e aos estudantes por participarem das oficinas sobre o tema.

\section{REFERÊNCIAS}

[1] da SILVA, P.H., da SILVEIRA, R.B., APPEL, M.H., MANGILI, O.C., GREMSKI, W., VEIGA, S.S. Brown spiders and loxoscelism. Toxicon 44: 693-709, 2004.

[2] FUTRELL, J. M. Loxoscelism. Am J Med Sci. 304: 261-267, 1992.

[3] GREMSKI, L. H., JUSTA, H. C., SILVA, T. P., POLLI, N.L.C., ANTUNES, B., MINOZZO, J. C., WILLE, A. C. M., SENFFRIBEIRO, A., ARNI, R. K., VEIGA, S.S. Forty years of the description of Brown spider venom phospholipases-D. Toxins, v. 12 , p. $1,2020$.

[4] SARAIVA, J, L. Papel da extensão universitária na formação de estudantes e professores / Role of the university extension in the student and teacher form ation Brasília méd ; 44(3): 225-233, 2007. 


\section{Capítulo 18}

Uma abordagem sobre a ecologia e biologia da aranha marrom para o quarto ano do Ensino Fundamental em escola da Rede Pública Municipal de Ponta Grossa, PR

Caroline Amanda da Silva

Pamela Renata Oliveira Pontarolo

Bruno Abel Resende Silva

Ana Carolina Martins Wille

Cristina Lúcia Sant'Ana Costa Ayub

Resumo: As aranhas são animais peçonhentos bastante comuns e podem ser encontradas em quase todos os continentes. Entre os gêneros de aranhas de importância médica destaca-se o Loxosceles, com aranhas popularmente conhecidas aranhasmarrom. As picadas de aranhas Loxosceles são consideradas um problema de saúde pública no Brasil. Em áreas urbanas do estado do Paraná e Santa Catarina têm ocorrido inúmeros acidentes e este fato pode estar associado ao desequilíbrio ambiental e ausência de predadores. As aranhas deslocadas de seu ambiente natural se abrigam em residencias humanas em caixas, armários, brechas de paredes, gavetas e roupas. Baseando-se no descrito acima, neste projeto, foram trabalhados aspectos sobre a ecologia e biologia das aranhas marrom com alunos do quarto ano de uma escola municipal do município de Ponta Grossa, PR. 0 objetivo final foi construir 0 conhecimento acerca do tema para que os alunos participantes se tornassem disseminadores do conhecimento científico sobre as aranhas marrom levando à sua comunidade informações sobre características, gênero, habitat e maneiras de evitar a infestação em ambientes humanos. Ao final aprenderam a construir o ciclo de vida das aranhas marrom e elaboraram uma maquete demonstrando que a aprendizagem foi efetivamente construída durante a realização do trabalho.

Palavras-chave: aranha marrom, recursos didáticos, ensino fundamental . 


\section{LABORATÓRIO DE RECURSOS DIDÁTICOS EM CIÊNCIAS MORFOLÓGICAS}

\section{$2^{\mathrm{a}}$ EDIÇÃO}

\subsection{PÚBLICO-ALVO}

Alunos do quarto ano de uma escola municipal de Ponta Grossa, Paraná (PR).

\subsection{MUNICÍPIOS ATINGIDOS}

Ponta Grossa, PR.

\subsection{LOCAL DE EXECUÇÃO}

Universidade Estadual de Ponta Grossa, Setor de Ciências Biológicas e da Saúde, Departamento de Biologia Estrutural, Molecular e Genética, Laboratório M69. Escola Municipal Professora Armida Frare Gracia, Ponta Grossa, PR.

\section{JUSTIFICATIVA}

No Brasil e no mundo são encontradas diversas espécies de aranhas, dentre todas elas, as aranhas do gênero Loxosceles também conhecidas como "aranhas marrom" merecem destaque pelos acidentes que causam e pelas manifestações clínicas que ocorrem após o envenenamento. Na região sul em áreas urbanas dos estados do Paraná e Santa Catarina a espécie predominante é a Loxoscelesintermedia, tal fato pode estar associado ao desequilíbrio ambiental e ausência de predadores (MARQUES-da-SILVA e FISCHER, 2005). As aranhas deslocadas de seu ambiente natural se abrigam em caixas, armários, brechas de paredes, gavetas e roupas, podendo desta forma entrar em contato direto com homens ou animais domésticos e causar os acidentes (FISCHER, M.L. e VASCONCELLOS-NETO, J., 2005).

As aranhas do gênero Loxosceles provocam um conjunto de sinais e sintomas nos acidentados denominado loxoscelismo que pode desencadear o quadro cutâneo ou dermonecrótico (maioria dos casos) e o quadro cutâneo-visceral ou sistêmico(GREMSKI, et al., 2020).

A população tem acesso somente a informações superficiais a respeito de aranhas-marrom e loxoscelismo, muitas delas, mistificadas e errôneas. Portanto, o objetivo deste trabalho foi contribuir trazendo informações mais atualizadas e científicas sobre as aranhas marrom paraalunos doquartoano matutino do Ensino Fundamental da Escola Municipal Professora Armida Frare Gracia, Ponta Grossa-PR para que estes levem informações atualizadas sobre o que aprenderam à comunidade em que vivem, tornando-se disseminadores de conhecimento. Vale ressaltar aqui, que o trabalho desenvolvido faz parte do projeto de extensão intitulado: "Laboratório de Recursos Didáticos em Ciências Morfológicas: 2ª Edição".

De acordo com o Conselho Nacional de Educação e Câmara de Educação Superior, capítulo I (da concepção, das diretrizes e dos princípios), art. 3ํa Extensão na Educação Superior Brasileira é a atividade que se integra à matriz curricular e à organização da pesquisa, constituindo-se em processo interdisciplinar, político educacional, cultural, científico, tecnológico, que promove a interação transformadora entre as instituições de ensino superior e os outros setores da sociedade, por meio da produção e da aplicação do conhecimento, em articulação permanente com o ensino e a pesquisa (RESOLUÇÃO CNE/CES 7/2018).

Diante do exposto acima, o trabalho desenvolvido enquadrou-se no contexto de extensão universitária em que matem o contato da educação superior com a comunidade. 0 trabalho desenvolvido veio a contribuir tanto com os alunos do ensino fundamental participantes do trabalho e suas famílias indiretamente envolvidas proporcionando-lhes "o saber", bem como, com os acadêmicos participantes direcionando-os a formação de sujeitos reflexivos e atuantes na sociedade. 


\section{OBJETIVOS}

\subsection{GERAL}

Levar conhecimentos aos alunos do quarto ano do ensino fundamental de uma escola municipal de Ponta Grossa sobre a biologia e ecologia das aranhas marrom para que sejam disseminadores do que aprenderam para suas comunidades.

\subsection{ESPECÍFICOS}

$\checkmark \quad$ Levar conhecimentos sobre as características das aranhas do gênero Loxosceles para os estudantes do quarto ano do ensino fundamental por meio de recursos didáticos lúdicos e construção de maquetes;

$\checkmark \quad$ Mostrar aos estudantes participantes do projeto o ciclo de vida e habitat naturais das aranhas marrom;

$\checkmark \quad$ Mostrar para os estudantes as consequências do desequilíbrio ambiental e como isto pode ter levado as aranhas marrom a ocupar ambientes humanos;

$\checkmark \quad$ Promover a interação dos acadêmicos da Universidade Estadual de Ponta Grossa com a comunidade local; Ponta Grossa;

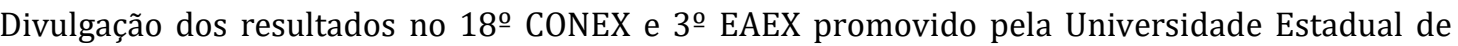

\section{METODOLOGIA}

- Encontro com os responsáveis pela Escola Municipal Professora Armida Frare Gracia, Ponta Grossa-PR com a finalidade de explicar o projeto esolicitar autorização para o desenvolvimento do mesmo;

- Após a autorização para a realização das atividades na escola, encontro com os estudantes do quarto ano com uma conversa prévia sobre o tema a fim de diagnosticar e quantificar o conhecimento dos mesmos sobre o tema a ser trabalhado;

- Baseado nas dúvidas, indagações e afirmações feitas pelos estudantes sobre o tema, obtenção de materiais didáticos para utilizar nas oficinas práticas;

- Oficinas práticas, com os alunos divididos em grupos, para a montagem das maquetes sobre aranhas e seu ciclo de vida, sob orientação da equipe do evento;

- Distribuição de atividades lúdicas como desenhos para colorir e palavras cruzadas para fixação do conteúdo e verificação da aprendizagem;

- Reunião com o grupo para verificar os resultados do trabalho;

\section{RESULTADOS}

Durante as atividades os alunos passaram a refletir sobre o papel das aranhas na natureza e o quanto a interferência humana pode interferir no habitat e ecologia destes animais. Além disso, os estudantes demonstraram ter aprendido muito sobre o tema, algo que foi verificado nos desenhos sobre o habitat natural e adquirido, ciclo de vida e atividades de palavras cruzadas (Figura 1).

O trabalho também proporcionou a interação da Universidade com a comunidade, aproximando o saber científico diretamente aos estudantes e indiretamente aos seus pares pela transmissão do conhecimento adquirido aos familiares e pessoas próximas.

Também foi possível promover a articulação entre ensino, pesquisa e extensão, pois os envolvidos na realização da oficina têm trabalhado em projetos de pesquisa sobre o tema e atuaram como mediadores na construção do processo de aprendizagem. 
Figura 1: Foto dos estudantes do quarto ano da Escola Municipal Professora Armida Frare Gracia, Ponta Grossa-PR, realizando as atividades propostas pela equipe organizadora do evento na oficina sobre aranha marrom.

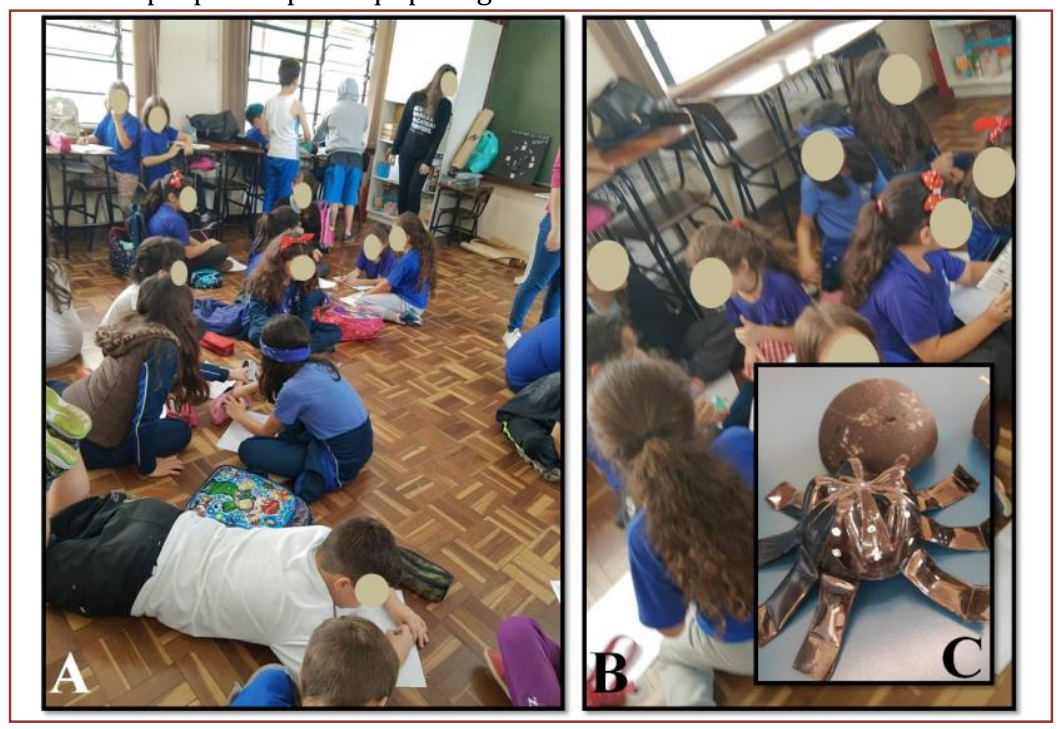

Em A, os estudantes estão realizando desenhos sobre o ciclo de vida das aranhas, em B elaborando maquetes sobre aranhas. Em $\mathrm{C}$, maquete de uma aranha respeitando aspectos biológicos como números de pares de patas e características corporais (número de olhos, cefalotórax e abdome). * Os rostos dos estudantes foram mascarados para evitar a identificação e exposição dos menores.

Por fim, foi possível diagnosticar a importância do trabalho realizado pelos relatos dos estudantes, a partir de sua realizaçãosabiam diferenciar aranhas marrom (gênero Loxosceles) de outras, sabiam sobre a ocorrência destas aranhas em seu ambiente natural, domiciliar e escolar e apresentaram hipóteses para minimizar os problemas sobre a infestação de aranhas marrom em ambientes humanos. Mostraram-se muito participativos e entusiasmados afirmando que iriam, quando chegassem em suas casas, verificar roupas e demais objetos para observar a existência de aranhas marrom.

\section{CONSIDERAÇÕES FINAIS}

Foi com grande entusiasmo e alegria que os integrantes da escola receberam a equipe executora deste trabalho. Os alunos foram muito participativos sempre trazendo novas indagações e relatos do que vivenciaram sobre o tema em seus ambientes; a escola sempre se mostrou muito receptiva para a realização do projeto propondo outras novas atividades à equipe executora.

\section{APOIO}

À PROEX da Universidade Estadual de Ponta Grossa por promover o desenvolvimento deste trabalho, aos gestores e professores da Escola Municipal Professora Armida Frare Gracia por autorizar e estimular a realização do trabalho nas suas dependências e a todos os estudantes e professores envolvidos.

\section{REFERÊNCIAS}

[1] FISCHER, M.L., VASCONCELLOS-NETO, J. Microhabitats occupied by Loxosceles intermediaand Loxosceles laeta(Araneae: Sicariidae) in Curitiba, Paraná, Brazil. J. Med. Entomol. 42: 756-765, 2005.

[2] GREMSKI, L. H., JUSTA, H. C., SILVA, T. P., POLLI, N.L.C., ANTUNES, B., MINOZZO, J. C., WILLE, A. C. M., SENFF-RIBEIRO, A., ARNI, R. K., VEIGA, S.S. Forty years of the description of Brown spider venom phospholipases-D. Toxins, v. 12, p. 1, 2020.

[3] MARQUES-DA-SILVA, E.; FISCHER, M.L. Distribuição das espécies do gênero Loxosceles Heineken \& Lowe, 1835 (Araneae; Sicariidae) no Estado do Paraná. Revista da sociedade brasileira de medicina tropical 38: 331-335, Brasil, 2005.

[4] RESOLUÇÃo CNE/CES 7/2018. Diário Oficial da União, Brasília, 19 de dezembro de 2018, Seção 1, pp. 49 e 50. 


\section{Capítulo 19}

\section{Arboviroses como tema norteador de Educação Ambiental e Sustentabilidade na Educação Básica}

\section{Rogério Ferreira da Silva}

Cleyton da Silva Maciel

Ana Beatriz dos Santos Araújo

Resumo: As arboviroses são doenças causadas por arbovírus, que são vírus que usam insetos como vetores. Destaca-se o arbovírus aedes aegypti transmissor da dengue, zika e chikungunya. 0 índice destas doenças aumenta a cada ano. Diante deste cenário, o objetivo deste trabalho é desenvolver atividades lúdicas com crianças e adolescentes sobre arboviroses, associando o tema com educação ambiental e sustentabilidade. Com isso, foi possível envolver crianças e adolescentes com o tema, conscientizá-los com o uso de oficinas para plantio de mudas e confecção de materiais reaproveitados para combater proliferação de mosquitos e redução de focos. Contudo, entende-se a importância das atividades realizadas em escolas e orfanatos para formação de adultos conscientes e preocupados com as questões de meio ambiente e de saúde pública.

Palavras-chave: Arboviroses, Educação Ambiental, Educação Infantil, Metodologias Ativas. 


\section{INTRODUÇÃO}

Um grande desafio na atualidade é o combate às arboviroses, que tem aumentado o número de casos nos últimos anos. Os arbovírus são vírus que possuem insetos como seus vetores (Lopes et al, 2014).

Em relação aos vetores, podemos destacar o Aedes Aegypti o qual é transmissor da dengue (também a dengue hemorrágica), chikungunya, zika vírus e febre amarela, podendo deixar sequelas no indivíduo, desde dores musculares a outras doenças como a hepatite. Infelizmente, a gravidade da situação clínica só é realmente notada quando ocorre uma "explosão" da doença em um determinado lugar (Revista de Saúde Pública, 2017). Se tratando ainda do mosquito, a OS-Santa Catarina (2017) afirma:"O Aedes aegypti é um mosquito doméstico, que vive perto do homem. Ele tem hábitos diurnos e alimenta-se de sangue humano, sobretudo ao amanhecer e ao entardecer". Diante de muitas especulações sobre os mosquitos já nascerem infectados, ela completa: "[...] Se a fêmea estiver infectada pelo vírus da dengue, chikungunya e zika, quando realizar a postura de ovos, há a possibilidade de as larvas já nascerem com o vírus - a chamada transmissão vertical". Conforme o Instituto Oswaldo Cruz (IOC/Fiocruz), a fêmea do mosquito (sendo a única capaz de picar) fica infectada após sugar o sangue de algum outro organismo que tenha partículas do vírus ainda circulando na corrente sanguínea. Então, ao adquirir o vírus e este passar um determinado tempo se desenvolvendo dentro do organismo do mosquito torna a fêmea infectada, pois já está pronto para ser transmitido, voltando ao ciclo novamente. Após a transmissão, o indivíduo infectado começará a demonstrar sintomas em seu corpo, como no caso da Dengue, que tem como indícios pintas vermelhas na pele, febre alta, mal-estar e cansaço extremo, dor abdominal em todo o corpo, dor de cabeça e no fundo dos olhos. No caso da Chikungunya febre alta, dor nos olhos, cansaço, dor nas articulações, coceiras e manchas na pele. No Zika vírus: dor de cabeça constante, dor de garganta, dor nas articulações, dor muscular e cansaço excessivo. E, na Febre Amarela: náusea e vômito, dor de cabeça, pele e olhos amarelos ou sangramento, febre, calafrio, dentre outros.

Dentre as variadas formas de prevenção e combate, vale ressaltar as plantas repelentes: meio sustentável e alternativo de auferir controle sobre os demais casos de infecção pelo arbovírus. Algumas liberando seu respectivo cheiro de modo que, o resultado seja mais eficaz do que outras plantas com a mesma finalidade. Carneiro (2015) declara: "A citronela é uma planta aromática que ficou conhecida por fornecer matériaprima (óleo essencial) para a fabricação de repelentes contra mosquitos e borrachudos. Considerado um ótimo repelente, o óleo da citronela é rico em compostos que afastam os mosquitos com eficácia”. Deste modo, vê-se que a eficácia dessas plantas, em sua maior parte encontra-se no seu aroma característico.

A propagação de tal conhecimento é bastante salutar, sobretudo, no uso de estratégias para transmissão lúdica destes conhecimentos na educação de base, formando crianças e adolescente preocupados com o tema e motivados a ter ações que promovam a redução dos casos de arboviroses em suas comunidades. 0 incentivo à divulgação e aplicação dos aprendizados se daria pelo conhecimento adquirido por consequência do entusiasmo, gerado pelo entretenimento em atividades práticas e dinâmicas (SOUZA, 2016).

Contudo, este artigo tem como objetivo ressaltar a importância do combate às arboviroses por meio do ensino lúdico dos conhecimentos, estes adequados às faixas etárias do público alvo - as crianças e os adolescentes - através de um projeto de extensão do Instituto Federal de Educação, Ciência e Tecnologia de Pernambuco - Campus Belo Jardim.

\section{METODOLOGIA}

- Preparação da equipe de alunos do ensino médio técnico multidisciplinar, tendo alunos dos cursos de Agroindústria, Agropecuária e Informática para atuar como multiplicadores dos conhecimentos sobre arboviroses e plantas repelentes num orfanato e escolas da cidade de Belo Jardim;

- Participação da equipe em frequentes reuniões para discussão do tema com base em pesquisas prévias, preparação e apresentação de seminários para avaliação de uma equipe multidisciplinar de professores, constituída de químico, biólogo, agrônomo e engenheiros de alimentos.

- Visitas ao público alvo, com o objetivo de familiarização e aplicação de atividades com os indivíduos beneficiários do projeto e avaliação do perfil comportamental destes, para a obtenção dos melhores métodos para aplicação do projeto.

- Capacitação dos integrantes do projeto para aplicação eficiente do programa previsto. 
- Circuito de apresentações sobre o tema a pré-adolescentes e adolescentes do anos finais do ensino fundamental de escolas públicas.

- Circuito de apresentações de seminários por cada discente integrante da equipe do projeto aos demais, sobre temas pertinentes e possíveis novos horizontes.

- Criação de jogos e atividades lúdicas, associadas ao projeto.

A metodologia citada pode ser aplicada com a utilização de técnicas e materiais que provoquem interesse nos indivíduos, sobretudo, nas crianças. Dentre as formas de aplicação temos: uso de tecnologia (plataformas educacionais, jogos educativos diversos e apps, por exemplo), oficinas, que é uma forma na qual as crianças e adolescentes sentem-se mais envolvidos, dança utilizando músicas com tema educacional, teatro, entre outros. No quesito dos materiais a serem usados na ação temos: velas repelentes (com óleo de citronela), Datas Show - apresentações nas escolas, garrafas pet, materiais para pintura e desenho (tintas, lápis, pincéis, cartolina etc.), materiais para construção de jogos (papéis impressos, dados etc.) tinta guache e papelão para desenvolver armadilhas para captura de mosquitos.

\section{RESULTADOS E DISCUSSÃO}

Na tentativa de introduzir o tema de uma maneira lúdica ao público-alvo, fez-se necessário a utilização de metodologias ativas - técnicas que diferem do ensino tradicional aplicado em ambientes de aprendizado. Neste método de ensino aprendizagem, o aluno se torna o protagonista da ação o qual é supervisionado e orientado pelo professor (ou responsável). Com a alteração do agente passivo (aluno) para o ativo (professor), o indivíduo, agora, com um maior contato com os materiais e a ação em si, acaba, consequentemente, desenvolvendo um certo interesse pelo assunto, já que foi permitido a interação de forma prática com o mesmo. A ludicidade, tão importante para a saúde mental humana, precisa ser mais considerada; o espaço lúdico da criança está merecendo maior atenção, pois é o espaço para a expressão mais genuína do ser, é o espaço de exercício da relação afetiva com o mundo, com as pessoas e com os objetos. (CUNHA, 2005 p. 09). Desta forma, o indivíduo passa a enxergar a brincadeira (ou jogos, danças, músicas, entre outros) como uma forma altamente prazerosa de se aprender qualquer coisa em qualquer ambiente, com os materiais necessários e um responsável disposto a ajudá-lo no que for preciso, mas sempre deixando-o participar de forma ativa no processo.

Metodologias ativas são processos interativos de conhecimento, análise, estudos, pesquisas e decisões individuais ou coletivas, com a finalidade de encontrar soluções para um problema (BASTOS, 2006; BERBEL, 2011 ). 0 desenvolvimento de práticas de ensino, eficientes em seus efeitos de transmissão de dados e ações a alunos, principalmente a crianças e adolescentes faz-se primordial no presente tempo e situação atual da sociedade. Com isso em mente, foram desenvolvidas possíveis e aplicáveis técnicas que podem ser utilizadas em diversos contextos, como o de ensino de educação ambiental e de cuidados com a própria saúde e da comunidade. Essas, geraram diversos resultados notáveis, como o aumento do interesse dos discentes do projeto no aprendizado, tendo em vista que o percebem como algo divertido e descontraído, como uma brincadeira. Adjunto, a criação de um olhar altruísta voltado aos cuidados ambientais, sociais e de saúde pública, por estarem a atuar ajudando e protegendo o meio ambiente, as pessoas ao seu redor e assim mesmos. Tais resultados obtidos através de brincadeiras, jogos, oficinas e apresentações teatrais. As atividades lúdicas que aguçam a curiosidade e que tornem o aprendizado divertido, é uma forma de promover interesse em alunos, promover o exercício da cidadania e de se apropriar do conhecimento mais efetivamente, isto facilita a inserção de temas que vão além da sala de aula e repercutem diretamente na vida dos indivíduos integrantes da família e da comunidade, amenizando impactos de temas de saúde pública como, por exemplo, as arboviroses (SILVA et al, 2019).

Ainda como resultado do projeto, destaca-se a expansão dos conhecimentos para novos lugares. Em primeira instância para a cidade vizinha, São Bento do Una, por meio de escolas públicas de ensino fundamental - o Colégio Cônego João Rodrigues e a Escola Lenita Fontes Cintra. Porém, em tempos de pandemia, não foi possível promover as ações presenciais do projeto. Com isso, foi criado um Instagram, que tem atingido diversas discentes e docentes das cidades circunvizinhas à cidade de aplicação do projeto, consequentemente, levando o conhecimento e espalhando cada vez mais a problemática atrelada as arboviroses. Dentre suas funcionalidades e facilidades desta mídia social, encontram-se a possibilidade de estar presente diariamente na vida do público-alvo, por meio dos stories e com publicações temáticas frequentes, além de permitir o feedback dos envolvidos. 0 reflexo deste envolvido está no aumento de visitas ao perfil, que tem aumentado semanalmente. 


\section{CONSIDERAÇÕES FINAIS}

Conclui-se que as ações desenvolvidas nesse projeto se fazem de grande importância para toda a sociedade. Impactando grandemente a educação infantil e a saúde pública. A família, escola e todos que possuem em suas mentes o desejo de fazer uma sociedade melhor, devem propagar tais conhecimentos para as crianças e adolescentes, tanto em suas casas, quanto em instituições de ensino fundamental, visando a resolução desses impasses na saúde. Ao implementar um projeto de educação ambiental associado a um combate de um problema de saúde pública, no caso, as arboviroses, permitir-se-á uma compreensão fundamental dos problemas existentes, da presença humana no ambiente, da sua responsabilidade e do seu papel crítico como cidadãos. Desenvolve-se assim, as competências e valores que conduzirão a repensar e avaliar de outra maneira as suas atitudes diárias e as suas consequências no meio ambiente em que vivem (ROOS \& BECKER, 2012).

\section{REFERÊNCIAS}

[1] BARROS, Aline et al. JOGOS E BRINCADEIRAS NA EDUCAÇÃO INFANTIL. 2016.

[2] BASTOS, C. C. Metodologias ativas. 2006. Disponível em:. Acesso em: 31 ago. 2019.

[3] BERBEL, N. A. N. As metodologias ativas e a promoção da autonomia de estudantes. Semina:Ciências Sociais e Humanas, Londrina, 32, 1, 25-40, 2011.

[4] BRASIL. Rev. Saúde Pública vol.51. São Paulo, 2017. Epub Apr 10, 2017. Arboviroses emergentes no Brasil: desafios para a clínica e implicações para a saúde pública. Scielo. Disponível em: . Acesso em: 7 de mar. de 2016.

[5] CARNEIRO, W. V. Óleo essencial de citronela: Avaliação do seu potencial como repelente veiculado em uma loção cremosa. 2015.

[6] GAETA, C.; MASSETO, M. Metodologias Ativas e o Processo de Aprendizagem na Perspectiva da Inovação. In: PBL 2010 Congresso Internacional. São Paulo, Brasil, 2010.

[7] LOPES, N. et al. Características gerais e epidemiologia dos arbovírus emergentes no Brasil. Rev. Pan-Amaz Saude. 5, 3, 55-64, 2014.

[8] MORAIS, E., ARAÚJO, E. JOGOS E BRINCADEIRAS: O Lúdico na Educação Infantil e o Desenvolvimento Intelectual. 2018.

[9] ROSS, A., BECKER, E. Educação ambiental e sustentabilidade. Revista Eletrônica em Gestão, Educação e Tecnologia Ambiental REGET/UFSM, v(5), n5, p. 857 - 866, 2012.

[10] SANTANA, K. C. A importância da educação infantil para o desenvolvimento do indivíduo. In: CONGRESSO NACIONAL DE EDUCAÇÂO, 3., 2016. Natal. Anais... Rio Grande do Norte, 2016.

[11] SILVA, R. F., SANTOS, D. F. C., SANTOS, E. M., MACIEL, C. S. Controle das Arboviroses com Plantas Repelentes, Conscientização na Educação Infantil, VI Congresso Nacional de Educação, 2019.

[12] SOUZA, D. B. 0 ensino e a aprendizagem através de jogos e brincadeiras. In: CONGRESSO NACIONAL DE EDUCAÇÂO, 3, 2016, Natal. Anais... Rio Grande do Norte, 2016.

[13] VALLE, D. Dengue, vírus e vetor: Aedes e dengue: vetor e doença. Disponível em: < http://www.ioc.fiocruz.br/dengue/textos/aedesvetoredoenca.html >. Acessado em 30 de agosto de 2020.

[14] CUNHA, Nylse Helena Silva. Brinquedos, desafios e descobertas. Petrópolis, RJ: ed. Vozes, 2005. 


\title{
Capítulo 20
}

\section{Uso do Stop Motion como sensibilizadora no estudo da Educação Ambiental}

\author{
Viviane Marques Sousa e Silva \\ Leticia Sousa dos Reis
}

Resumo: A relação existente entre o homem e o meio ambiente encontra-se, de certa forma, numa perspectiva voltada exclusivamente para a exploração econômica, estamos vivendo em uma geração de consumo exarcerbado, onde cada vez é maior a produção de materiais descartáveis, quase sempre por se tornar obsoleto, o que contribui com prejuízos à vida em nosso Planeta, interferindo significativamente na qualidade de vida do ser humano. A preocupação em preservar o meio ambiente foi gerada pela necessidade de oferecer à população futura as mesmas condições e recursos naturais de que dispõe a geração presente. (OLIVEIRA e SOUZA-LIMA. 2006, p 21). Em consonância com este pensamento, a problemática lançada para investigação foi analisar como está o meio ambiente hoje, como provavelmente ficará décadas à frente e que atitudes são convenientes nos dias de hoje. A alma desta proposta pedagógica interdisciplinar é a sensibilização quanto às problemáticas ambientais, fundamentando-se no que rege a Base Nacional Comum Curricular (BNCC), e o Projeto de Intervenção Pedagógica (PIP) da escola, abordou-se a temática através da produção de filmes de curta duração utilizando a técnica Stop Motion (movimento parado), pela disposição sequencial de fotografias de um objeto simulando o movimento. 0 projeto desenvolveu-se numa escola pública (Massaranduba-PB), transcorrendo em quatro etapas: 1- Apresentação da técnica de produção de filmes aos alunos; 2 - Sensibilização quanto à importância do meio ambiente, com exposição do vídeo "A história das coisas", e palestra interdisciplinar; 3 - Formação dos grupos e delegação de tarefas, respeitando as habilidades dos alunos; 4 - Ação sensibilizadora na escola, onde foram exibidos os filmes produzidos, além dos materiais de apoio confeccionados pelos alunos. Verificou-se uma notória mudança comportamental nas dependências da escola, aumento do rendimento escolar e diminuição da evasão, o que nos permite afirmar que o projeto constituiu-se um importante instrumento de conhecimento, de integração e modificador do pensamento crítico dos alunos.

Palavras-chave: Educação ambiental, interdisciplinaridade, meio ambiente, educação Física, ensino de química. 


\section{INTRODUÇÃO}

A relação existente entre o homem e o meio ambiente se encontra, de certa forma, numa perspectiva voltada exclusivamente para a exploração econômica, estamos vivendo em uma geração de consumo exacerbado, onde, cada vez é maior a produção de materiais que são descartados diariamente, contribuindo com prejuízos à vida em nosso Planeta, acarretando uma série de problemas que interferem significativamente na qualidade de vida do ser humano.

"A preocupação em preservar o meio ambiente foi gerada pela necessidade de oferecer à população futura as mesmas condições e recursos naturais de que dispõe a geração presente." (OLIVEIRA e SOUZA-LIMA. 2006, p 21). Baseando-se neste pensamento, a problemática lançada para investigação foi, como está o meio ambiente hoje, como provavelmente ficará décadas à frente e que atitudes devemos tomar para que o meio ambiente seja preservado para as próximas gerações.

Fundamentando-se no que rege a Base Nacional Comum Curricular - BNCC, para o Ensino básico, A alma da pesquisa é sensibilizar os alunos quanto às problemáticas ambientais, onde a abordagem ao tema Educação Ambiental ocorreu através da conscientização referente aos hábitos alimentares a partir da problemática do desperdício abordada no documentário "Ilha das Flores".

A proposta em trabalhar com os alunos a prática de atitudes conscientes e sustentáveis baseadas nos conteúdos programáticos da disciplina de química e Educação Física, surgiu da observação comportamental do alunado: Consumo exagerado de alimentos industrializados, o descarte inadequado do lixo; descompromisso com o ambiente escolar; consumismo elevado; bem como o posicionamento indiferente aos problemas ambientais da cidade, o que remete à falta de conhecimento e pouca importância referente aos valores que o "meio ambiente" agrega e representa à sua volta.

Os alunos do ensino médio, preocupando-se com a aprovação, seja no ano letivo, como no Enem, julgam decorar conteúdos e fórmulas como sendo o meio mais eficiente e prático para alcançar o que almejam. Sendo assim, o objetivo do processo educacional perde totalmente sua essência. Como se sabe, visamos formar cidadãos críticos e conscientes da realidade, não pessoas eficientes em memorização.

0 modo de incentivá-los a trabalhar no projeto foi apresentá-los como as problemáticas detectadas conversam entre si e mostrá-los a relação direta que as disciplinas tem com o tema em discussão, especificamente o conteúdo do ano escolar em que estão, 3ํano do ensino médio.

A necessidade dos jovens em se sentirem partes integrantes de grupos e aceitos na comunidade, os levam ao desejo de possuir o que a mídia impõe como sendo o usável e aceito, gerando o consumismo exagerado e a alimentação inadequada midiaticamente incentivada, afetando diretamente a degradação do ambiente como também, à saúde dos nossos jovens.

"O consumo moderno é mediado pelas relações de mercado e assume a forma do consumo de mercadorias: o que equivale a dizer que, em geral, consumimos mercadorias, serviços e experiências que foram produzidos exclusivamente para serem vendidos no mercado de consumidores. (...) Um elemento fundamental do nosso consumo é o ato de escolher entre uma gama de mercadorias alternativas produzidas pelas instituições que não são interessadas em necessidades ou valores culturais, mas no lucro e em valores econômicos". (SLATER, 2002, p33).

Um outro fator relevante para este, é o modo com que tratam o ambiente escolar, a depredação de bens materiais da escola, tornando-os inadequados para o uso, faz com que gere o consumismo, pois para repor os mesmos, se faz necessário extração de matéria-prima, o que implica em impacto ambiental.

É válido lembrar que tivemos como alicerce o Projeto de intervenção Pedagógica (PIP) de nossa escola: "Saúde e Qualidade de Vida no Âmbito Escolar: Fomentando a Cidadania e a Dignidade da Pessoa Humana", desenvolvendo ações que viriam proporcionar uma melhor qualidade de vida dentro e fora da escola, conscientizando e sensibilizando-os a serem além de praticantes, multiplicadores dessas ações, sendo a comunidade estimulada para agir de acordo com esses objetivos através da propagação do conhecimento adquirido em vivência escolar pelos alunos, em suas residências.

\section{METODOLOGIA}

Para desenvolver uma metodologia de trabalho que possibilitasse a construção da consciência ecológica de forma eficaz e eficiente, a discussão foi lançada após a exibição do documentário "Ilha das Flores", complementando com a promoção de uma palestra, ocorrendo sessão de autógrafos de um autor ex-aluno da instituição, pesquisas, debates e produção textual para que a sensibilização fosse tenaz. 
Realizamos um passeio pedagógico por alguns pontos da cidade, analisando situações críticas por falta de consciência ambiental. Foi notória a mudança dos valores e de percepção.

Não houve imposição de tarefas, os alunos que se fizerem disponíveis a realizar e produzir de acordo com suas habilidades, o que fluiu de maneira dinâmica e divertida.

Realizamos a oficina culinária para aprendizado e degustação de alimentos com aproveitamento máximo, de maneira rotacional, a ultima estação realizava-se na cozinha da escola. Neste momento se fortaleceu a relação entre o projeto e os conteúdos programáticos. Dos alunos surgiu a ideia de desenvolver na escola um projeto de compostagem orgânica para manter uma horta escolar.

Por fim, houve a seleção pelos alunos, do cardápio que seria exposto na Lanchonete econômica e nutritiva durante a mostra pedagógica da escola. Transformou-se uma sala de aula em uma lanchonete. Enquanto os visitantes estavam nas mesas degustando, recebiam as explicações dos alunos, de forma sensibilizadora.

\section{REFERENCIAL TEÓRICO}

\subsection{EDUCAÇÃO AMBIENTAL E A QUÍMICA}

Quando o estudo da Química instiga aos alunos a uma visão crítica do mundo que os cerca, seu interesse pelo assunto aumenta, pois são dadas condições de perceber e discutir situações relacionadas a problemas sociais e ambientais do meio em que estão inseridos, contribuindo para a possível intervenção e resolução dos mesmos. É de fundamental importância que o conhecimento de Química seja relevante para o estudante, podendo ser relacionado com o seu dia a dia e com assuntos que afetam a sua vida e a sociedade em que está inserido.

Pode-se assim considerar que o ensino de Química como um cenário ideal para que reconheçam que o conhecimento químico e tecnológico é resultado do trabalho humano construído historicamente, a fim de desenvolver espírito crítico quanto ao papel da Química e demais ciências na solução de problemas gerais relacionados à manutenção da vida do homem e do planeta com qualidade.

Neste sentido, os conhecimentos químicos devem apontar para a formação de um cidadão cada vez mais comprometido com a sustentabilidade, principalmente nessa primeira década de início de século, de forma que suas práticas e atitudes corroborem com o planejamento social, na busca de uma sociedade mais justa e organizada. "É o conhecimento vivo que conduz a grande aventura da descoberta do universo, da vida, do homem." (MORIN, 2005).

A consciência de que o conhecimento científico é, assim, dinâmico e mutável ajudará o estudante e o professor a terem a necessária visão crítica da ciência. "Não se pode simplesmente aceitar a ciência como pronta e acabada e os conceitos atualmente aceitos pelos cientistas e ensinados nas escolas como "verdade absoluta" . (PCN - Ensino Médio, 2002).

Nesta mesma linha de pensamento PCN percebem que é notória necessidade de desenvolver um aprendizado que possibilite ao aluno a compreensão tanto dos processos químicos em si quanto da construção de um conhecimento científico em estreita relação com as aplicações tecnológicas e suas implicações ambientais, sociais, políticas e econômicas.

Nunca se deve perder de vista que o ensino de Química visa a contribuir para a formação da cidadania e, dessa forma, deve permitir o desenvolvimento de conhecimentos e valores que possam servir de instrumentos mediadores da interação do indivíduo com o mundo. Consegue-se, isso mais efetivamente ao se contextualizar o aprendizado, o que pode ser feito com exemplos mais gerais, universais, ou com exemplos de relevância mais local, regional.

\subsection{EDUCAÇÃOAMBIENTAL NAS AULAS DE EDUCAÇÃO FÍSICA}

Diante da afirmativa que o homem é parte integrante da natureza, formado pelos mesmos elementos em sua composição física e química, diferenciando-se na capacidade de pensar, agir e interferir, surge a necessidade de relacionar o homem com o meio ambiente.

Logo, a Educação Física Escolar, tem como importante objetivo promover aos alunos a percepção de serem integrantes, dependentes e agentes transformadores do ambiente, identificando seus elementos e as interações entre eles, contribuindo ativamente para a melhoria deste, ampliando de uma visão biológica, para dimensões afetivas, cognitivas e socioculturais. 
Para Caparroz e Bracht (2007), o professor de Educação Física deve ser autor de sua prática e não um mero reprodutor do que foi pensado por outros. 0 professor deve construir sua prática com referências em ações/experiências e em reflexões/teorias, desde que esse processo se dê de maneira autônoma e crítica, indicando a importância de uma formação inicial e continuada, além de bem estruturada, em Educação Ambiental, que ajude o professor na reflexão de sua ação, tanto prática quanto teórica.

Quanto aos conteúdos trabalhados na Educação Física Escolar, segundo Rodrigues e Darido (2006), podem ser temas e possibilidades de trabalho nas aulas de Educação Física que abordem a temática ambiental: o meio ambiente, a temperatura e aulas de Educação Física; Educação Física, lazer e espaço natural; Espaços disponíveis para as aulas de Educação Física; Saúde e natureza; Esportes de aventura e o meio ambiente, entre outros.

\subsection{EDUCAÇ̃̃O AMBIENTAL COMO TEMA TRANSVERSAL}

A Educação Ambiental - EA, foi firmada como lei na constituição Brasileira, em 27 de Abril de 1999, Onde, em seu Artigo $1^{\circ}$ e 2ํㅜ , respectivamente, lê-se:

"Entende-se por educação Ambiental os processos por meio dos quais o indivíduo e a coletividade constroem valores sociais, conhecimentos, habilidades, atitudes e competências voltadas para a conservação do meio ambiente, bem de uso comum do povo, essencial à sadia qualidade de vida e sua sustentabilidade.

A Educação Ambiental é um componente essencial e permanente da educação nacional, devendo estar presente, de forma articulada, em todos os níveis e modalidades do processo educativo, em caráter formal e não-formal" (Brasil, 1999).

0 foco do tema transversal é capacitar os alunos à assumirem, posicionamentos, coerentes, éticos e morais diante de situações que envolvem a vida coletiva, de forma responsável, no caso da EA, visa propagar o conhecimento sobre meio ambiente de forma que contribua para a preservação e utilização responsável dos recursos naturais.

Sendo assim, A EA, conversa com todas as áreas do conhecimento, ao ser entendida como um tema transversal, solicitando a interdisciplinariedade para que a sensibilização e conscientização seja efetivada.

\subsection{EDUCAÇÃO AMBIENTAL NAS PROVAS DO ENEM}

A temática da Educação Ambiental é, largamente, explorada nas provas do Enem, em todos os eixos educacionais, de forma contextualizada. Especificamente na área do conhecimento Ciências da natureza e suas tecnologias, o tema é abordado em até $24 \%$ de um total de 45 questões, o que afirma os objetivos do exame e o que se propõe nos PCN, que assinala que o trabalho de educação ambiental deve ser desenvolvido com a finalidade de ajudar os alunos a construírem uma consciência global das questões relativas ao meio para que possamassumir posições afinadas com os valores referentes à sua proteção e melhoria. Para isso, é importante que possam atribuir significado àquilo que aprendem sobre a questão ambiental. E esse significado é resutado da ligação que aluno estabelece entre o que aprende e a sua realidade cotidiana [...] A perspectiva ambiental oferece instrumentos para que o aluno possa compreender problemas que afetam a sua vida, a de sua comunidade, a de seu país e a do planeta (op. Cit., 1997, p.30).

\section{PROGRAMA COZINHA BRASIL}

Criado a partir de estudos que revelavam a baixa qualidade nutricional na alimentação dos brasileiros, o Programa Cozinha Brasil é uma iniciativa do SESI, desenvolvido em conjunto com a indústria para melhorar este quadro. 0 objetivo é estabelecer um processo educativo permanente, voltado a colaborar com a mudança de comportamento em relação à produção, preparação e consumo dos alimentos, promovendo assim uma cultura de saúde, bem-estar e sustentabilidade, através de com cursos de Educação alimentar onde ensinam a ter uma alimentação saudável, nutritiva, equilibrada e saborosa, contribuindo ainda para a diminuição do desperdício através do aproveitamento integral dos alimentos. 


\section{DOCUMENTÁRIO “ILHA DAS FLORES” COMO MATERIAL DIDÁTICO}

Trata-se de um curta-metragem de 13 minutos, produzido pelo o cineasta gaúcho Jorge Furtado em 1990, que recebeu vários prémios, entre eles o Urso de Prata para curta-metragem no Festival de Berlim neste mesmo ano. Em 2019 foi eleito pela Associação Brasileira de Críticos de Cinema como o melhor curta brasileiro de todos os tempos.

Em lha das Flores, é exposto a condição social em que vivem os habitantes de um bairro homônimo, na região metropolitana de Porto Alegre. Nele é narrado o caminho do tomate do campo de cultivo até o aterro sanitário, onde é disputado entre porcos e seres humanos famintos, mostrados com acidez, transparência dos fatos e linguagem quase científica para mostrar um passo a passo de como as relações entre seres humanos é desigual no sistema capitalista.

\section{RESULTADOS E DISCUSSÃO}

Diante do desenvolvimento do projeto, buscou-se trabalhar as dificuldades dos alunos, respeitar as habilidades individuais e comtemplar a interdisciplinaridade. Observou-se a dedicação primorosa dos alunos, dos detalhes e criatividade empenhados no desenvolvimento para o projeto. Este realmente atuou como Modificador de hábitos alimentares, a ideia foi muito comentada na cidade, atraindo um número excelente de visitantes, e estes não só degustavam, mas recebiam instruções valiosas dos alunos, já que nos cartazes encontravam-se as informações nutricionais dos principais alimentos de nosso estado, valorizando a cultura regional. Observou-se que dimunuiu o consumo de lanches industrializados, trazidos pelos alunos para a escola.

Foi notória a valorização do patrimônio escolar, descarte adequado dos resíduos e limpeza nas dependências da escola.

Os resultados obtidos foram satisfatórios, conseguimos reduzir o índice de faltas, e elevar a média de pontuação da turma, no $1^{\text {o }}$ Bimestre foi de 6,9, passando à 7,8 no $3^{\circ}$ Bimestre.

Pontuamos que dos alunos surgiram ideias de novos projetos para desenvolver na escola, o que deixa claro a sensibilização ocorrida de forma eficiente.

\section{CONSIDERAÇÕES FINAIS}

Fica registrado a importância de se estabelecer um diálogo entre a Educação Escolar e a Educação Ambiental. Não tratar o tema como preenchedor de currículo e/ou de tempo, necessitamos compreender que somos responsáveis por uma grande parcela dos valores que os alunos quanto cidadãos carregarão. A Educação Ambiental é modificadora de hábitos, apresenta uma clara capacidade de proporcionar uma melhor qualidade de vida para as pessoas. E isso, só se fará com conscientização e sensibilização, onde cada indivíduo sinta-se responsável em fazer algo para melhorar sua qualidade de vida, melhorar o ambiente de convívio e conter o avanço da degradação ambiental.

\section{REFERÊNCIAS}

[1] BRASIL. Base Nacional Comum Curricular (BNCC). Educação é a Base. Brasília, MEC/CONSED/UNDIME, 2017.

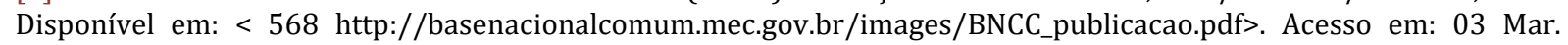
2019.

[2] BRASIL. Parâmetros Curriculares Nacionais para o Ensino Médio - PCNEM. Secretaria da Educação Média e Tecnológica. 2002; 2004.

[3] BRASIL. Ministério do Meio Ambiente. Lei n. 9.795/1999.

http://www.mma.gov.br/port/conama/legiabre.cfm?codlegi=321.

[4] CAPARROZ, F. E.; BRACHT, V. O tempo e o lugar de uma didática da Educação Física. Revista Brasileira de Ciências do Esporte, Campinas, 2007.

[5] FURTADO, Jorge. Ilha das 1990. https://www.youtube.com/watch?v=KAzhAXjUG28\&t=3s.

[6] FUNDAÇÃO VICTOR CIVITA. Ofício de Professor: Aprender mais para ensinar melhor - Meio ambiente e qualidade de vida. São Paulo: Fundação Vitor Civita, 2002.

[7] MORIN, E., Ciência com consciência, Rio de Janeiro: Bertrand Brasil, ed. 9ạ , 2005, 350p. 
[8] OLIVEIRA,Gilson Batista de. SOUZA-LIMA, José Edmilson. 0 desenvolvimento sustentável em foco: Uma contribuição multidisciplinar. Curitiba: Annablume, 2006.

[9] RODRIGUES, L. H.; DARIDO, S. C. Educação Física escolar e meio ambiente: reflexões e aplicações pedagógicas. FDeportes.com, Revista Digital.Buenos Aires, sep. 2006, v. $11, \quad$ n. 100. http://www.efdeportes.com/efd100/ma.htm

[10] SLATER, Don. Cultura do consumismo \& modernidade. São Paulo, Nobel, 2002. 


\title{
Capítulo 21
}

\section{As contribuições das atividades lúdicas no ensino da Educação Aambiental: Um relato de experiência}

\author{
Danilo Ramos Cavalcanti \\ Marcos de Figueiredo Andrade \\ Emanuella Barros de Souza Oliveira Alvares \\ Carlos Eduardo Gomes de Barros \\ Patrícia Mariana Vasco de Góz.
}

Resumo: As metodologias de ensino na modalidade prática aplicadas nas escolas muitas vezes remetem a um modelo tradicional. Para que o processo de ensino-aprendizagem seja atrativo aos alunos, se faz necessário estabelecer cenários pedagógicos que agucem a curiosidade e a busca por novos conhecimentos. As atividades lúdicas configuram-se como estratégias de se atingir a esse modelo de ensino mediador/construtivista. Sendo assim, o objetivo do presente estudo foi avaliar a eficácia das atividades lúdicas no ensino da EA, bem como, relatar as experiências vivenciadas nas intervenções pedagógicas. Trata-se de um relato de experiência realizado por meio de intervenções realizadas em uma escola pública do município de Escada - PE. A intervenção ocorreu em dois momentos, totalizando sete dias. No primeiro, foram executadas abordagens pedagógicas referentes à EA no espaço escolar, tendo por suporte metodológico a ludicidade e, no segundo momento, os alunos foram submetidos a uma avaliação sobre a viabilidade da proposta para o aprendizado. Com isso, Pode-se constatar que o lúdico favore de forma significativa no processo de ensino-aprendizagem da EA. As intervençõs tiveram boa aceitação pelos alunos que, a partir das discussões sinalizaram o interesse em aplicar os conhecimentos adquiridos em situações cotidianas.

Palavras-chave: Educação ambiental; Ludicidade; Reciclagem 


\section{INTRODUÇÃO}

As metodologias de ensino na modalidade prática aplicadas nas escolas muitas vezes remetem a um modelo tradicional, priorizando a reprodução e memorização de conceitos. Diante desse cenário, os estudantes não têm espaço para contextualizar os conteúdos trabalhados, assim como não participar das aulas de forma significativa, ocasionando em desinteresse e baixo rendimento na aprendizagem (CONDE; LIMA; BAY, 2013).

Para que o processo de ensino-aprendizagem seja atrativo aos alunos, se faz necessário estabelecer cenários pedagógicos que agucem a curiosidade e a busca por novos conhecimentos. Logo, a postura do professor deixa de ser autoritária e inflexível, passando a assumir características mediadoras e priorizando ações ativas dos alunos frente a sua formação estudantil. As atividades lúdicas configuram-se como estratégias de se atingir a esse modelo de ensino mediador/construtivista, favorecendo ao educando a construção e expressão de saberes de forma prazerosa, dinâmica, desmistificando a imagem monótona do ato de aprender (AZEVEDO; NEVES, 2009).

Segundo Almeida (1995), o termo "lúdico" origina-se do termo latino ludus que significa jogo (brincadeira). Esse, quando praticado no espaço escolar, aborda uma finalidade educativa, gerando benefícios ao aprendizado. Partindo então, do princípio de que a ludicidade no exercício pedagógico motiva a aprendizagem dos alunos, aplicaram-se atividades baseadas neste recurso, no ensino da Educação Ambiental (EA).

A EA no Brasil foi instituída pela LEI № 9.795/99, base da resolução № 2, de 15 de junho de 2012, que estabelece as Diretrizes Curriculares Nacionais da sua aplicabilidade em todos os níveis de ensino. 0 amparo legal da EA dispõe que ela seja desenvolvida de forma interdisciplinar, integrada a outros componentes curriculares. Desta forma, deve-se estar implícita em ações educativas diversas, no intuito de promover a cidadania e a consciência ambiental (MEDIANA, 2001).

0 ensino da EA deve ser voltado para propostas reflexivas, quanto à responsabilidade socioambiental para com planeta, individual e coletivamente, buscando medidas sustentáveis, no intuito de não comprometer o futuro das próximas gerações. A pergunta condutora do presente estudo foi: o lúdico contribui ou não de forma significativa no processo de ensino-aprendizagem na temática da EA?

O presente trabalho teve por objetivo avaliar a eficácia das atividades lúdicas no ensino da EA, bem como, relatar as experiências vivenciadas nas intervenções pedagógicas.

\section{METODOLOGIA}

Trata-se de um relato de experiência realizado por meio de intervenções realizadas em uma escola pública do município de Escada - PE, no mês de junho de 2017. A amostra foi composta por nove turmas dos anos iniciais do Ensino Fundamental. A intervenção ocorreu em dois momentos, totalizando sete dias. No primeiro, foram executadas abordagens pedagógicas referentes à EA no espaço escolar, tendo por suporte metodológico a ludicidade e, no segundo momento, os alunos foram submetidos a uma avaliação sobre a viabilidade da proposta para o aprendizado.

Ressalta-se que o grau de complexidade das atividades vivenciadas foi de acordo com a faixa etária dos estudantes. Para isso, foi realizado previamente um planejamento com os professores e a coordenação pedagógica da escola. Durante o período de intervenção ocorreu a realização de palestras, jogos (brincadeiras), oficinas de arte com materiais recicláveis, produção de cartazes, cartilhas e uma exposição dos materiais didáticos produzidos ao público.

As palestras ocorreram no primeiro dia e contaram com a participação de todos os alunos das nove turmas. Foram discutidos três eixos temáticos: 1- Coleta seletiva e seus benefícios ao meio ambiente; 2- Os 5R's da sustentabilidade (Repensar, Recusar, Reduzir, Reutilizar e Reciclar) e 3- 0 papel do consumidor frente ao consumo consciente.

A metodologia aplicada foi expositiva/dialogada, utilizando apresentações feitas em Microsoft PowerPoint 2007 como recurso didático. As apresentações continham tópicos textuais e imagens referentes aos conteúdos abordados. Em seguida, os discentes do 4o e 5o anos participaram de um jogo de perguntas e respostas, por meio do qual, de forma aleatória, pelo número da chamada da caderneta do professor, foram selecionados para responderem aos questionamentos.

No segundo e no terceiro dia de intervenção, foram realizadas as oficinas de arte com as turmas do $1^{\circ}$ ao 5o ano. Nesta fase, os alunos tiveram a oportunidade de produzir brinquedos e demais objetos com 
materiais reciclados, por meio da utilização de tampas de garrafa PET, palitos de picolé, papelão, embalagens de shampoo, CD, entre outros.

No quarto dia de intervenção, foram elaborados cartazes e cartilhas pelos alunos em todas as turmas. Nos cartazes foram pontuados tópicos sobre os eixos temáticos discutidos nas palestras, fazendo uso de imagens. Ao término, os mesmos, foram expostos nas diferentes repartições do prédio escolar. Quanto às cartilhas relatou-se o processo de ecoalfabetização, estabelecendo uma ponte entre teoria e prática, através da exemplificação de situações cotidianas diversas, voltadas a proteção dos recursos naturais. Cartolinas, fitas adesivas, pilotos, tesouras, imagens impressas e papéis de ofício reciclado, correspondem aos recursos utilizados neste dia.

A finalização das ações educativas deu-se no quinto dia, na unidade escolar, por meio da exposição dos materiais didáticos produzidos, aberta para a visitação do público. Participaram deste evento todo corpo docente e discente, os demais funcionários, os pais e/ou responsáveis pelos educandos, e os discentes visitantes de outras instituições. Momento rico de troca de conhecimentos voltados à manutenção do patrimônio natural.

As metodologias aplicadas tiveram por referência a Teoria da Aprendizagem Significativa (TAS) de David Paul Ausubel, que considera o conhecimento prévio, presente nas estruturas cognitivas do sujeito, como base para a construção do conhecimento científico e assimilação de novas informações (AUSEBEL; NOVAK; HANESIAN, 1980). Nesse aspecto, o educando é reconhecido como um ser portador de opiniões, tendo participação ativa, diante do contexto educativo.

Na segunda etapa do estudo, realizou-se uma pesquisa de abordagem qualitativa, com o alunado (180 alunos), para averiguar os resultados das atividades lúdicas no ensino-aprendizagem da EA. A coleta de dados ocorreu no sexto e sétimo dia, por intermédio de um questionário, composto pelas seguintes questões: 1- A proposta da ludicidade no ensino da EA foi válida para o seu aprendizado? 2- Esta vivência provocou mudanças em seu comportamento para com o meio ambiente?

Em seguida, os dados coletados foram organizados em gráficos, utilizando software Microsoft Excel 2007, e discutido sob a luz do referencial teórico, fundamentado nas ideias dos autores: Dias (2004) e Dohme (2008).

\section{RESULTADOS E DISCUSSÃO}

Dados promissores puderam ser reconhecidos na vivência das intervenções. Os alunos se mostraram compromissados e receptivos durante todas as atividades aplicadas, sendo nítida a sinergia nas turmas. Teve-se uma boa compreensão quanto aos objetivos pedagógicos preestabelecidos para cada ação. Esses resultados corroboram com as ideias defendidas por Dohme (2008), quando a mesma salienta que as atividades lúdicas nos anos iniciais do Ensino Fundamental, estimulam a participação dos discentes no processo de ensino e aprendizagem.

Dentre os brinquedos produzidos destacam-se: peão, carro, avião, jogo da dama, binóculo e o "vai vem". Já, com relação aos outros objetos, teve-se a produção de: porta lápis e caneta, porta joia, porta retratos e um baú. 0 baú confeccionado foi denominado de "baú da reciclagem" que tem por serventia armazenar todos os recursos produzidos. Esses recursos (brinquedos e objetos recicláveis) foram disponibilizados aos estudantes no momento de recreação. 0 intuito pedagógico das oficinas incumbiu-se de sensibilizar a comunidade escolar quanto à importância da reciclagem para a preservação do meio ambiente. Os discentes adquiriram noções sobre os princípios da coleta seletiva, e de como reutilizar os resíduos, além de desenvolverem suas criatividades e coordenação motora.

Observou-se nos momentos de discussões que parte dos estudantes já tinha certo domínio sobre a temática EA, porém, esse período condicionou ao esclarecimento das dúvidas ainda existentes. Outro benefício diagnosticado concerne à propagação dos conhecimentos e orientações educacionais para outros ambientes, além da escola, mediante da inserção dos visitantes, no dia em que ocorreu a exposição dos materiais didáticos produzidos, favorecendo assim, o uso coletivo das práticas sustentáveis. 
Conforme indica Dias (2004), por meio da EA a população toma consciência do seu meio ambiente e busca soluções ecológicas, tendo a intenção de resolver os problemas ambientais, pensando no futuro do planeta e no das próximas gerações.

Na figura (1) encontram-se registros visuais das ações lúdicas desenvolvidas no espaço escolar, sendo perceptível a integração entre os participantes.

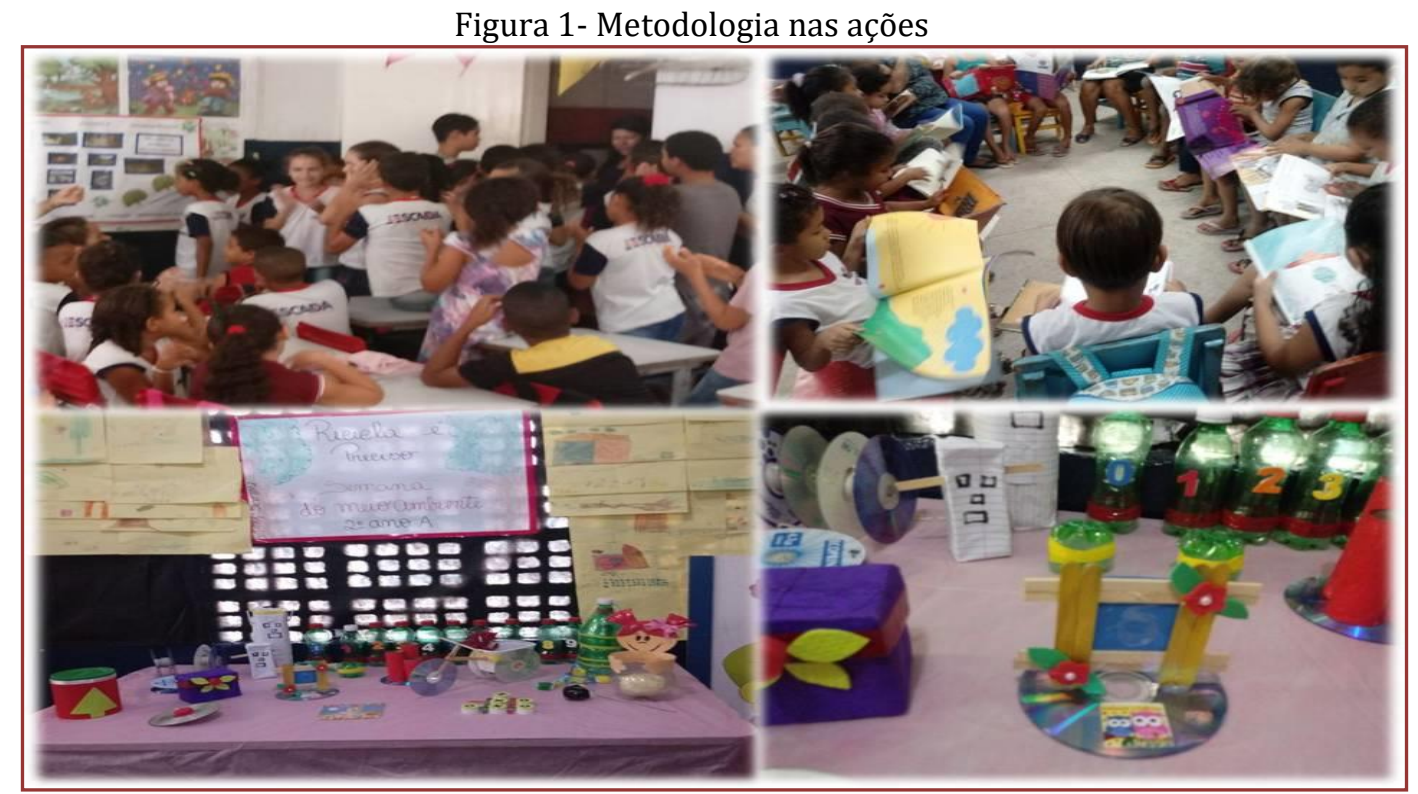

Fonte: Arquivo dos autores, 2017

Quanto ao questionário, os resultados obtidos revelam a aprovação da proposta por grande parte dos alunos. Inicialmente, os estudantes foram indagados sobre a viabilidade das ações lúdicas para o aprendizado da EA. Dos 180 respondentes, 160 confirmaram que a experiência contribuiu para o aprendizado, totalizando um percentual de $89 \%$. Os 11\% restante, deixaram em branco a questão, o que se catalogou como "não informado". No Gráfico (1), são destacados os percentuais que tange a primeira questão.

Gráfico 1. Questionário da pesquisa

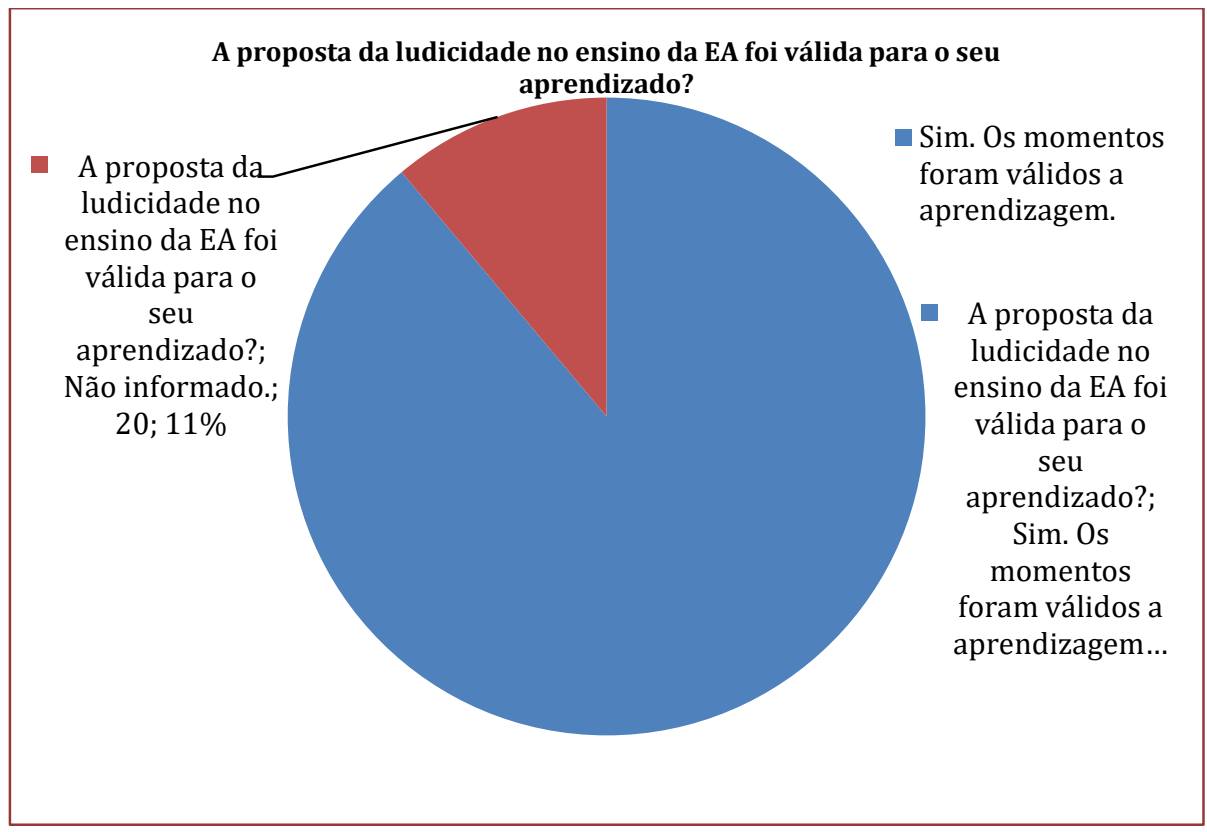

Fonte: Autores - com base nos dados coletados 
Na segunda questão, buscou-se comprovar se a vivência foi contribuinte na adesão de hábitos sustentáveis pelos discentes. As respostas apontam que 94\% (170 dos alunos) consideram que após as ações, passaram a refletir suas atitudes para com o meio ambiente. 0s 6\% restantes não responderam ao questionamento. Os dados encontram-se registrados no Gráfico 2.

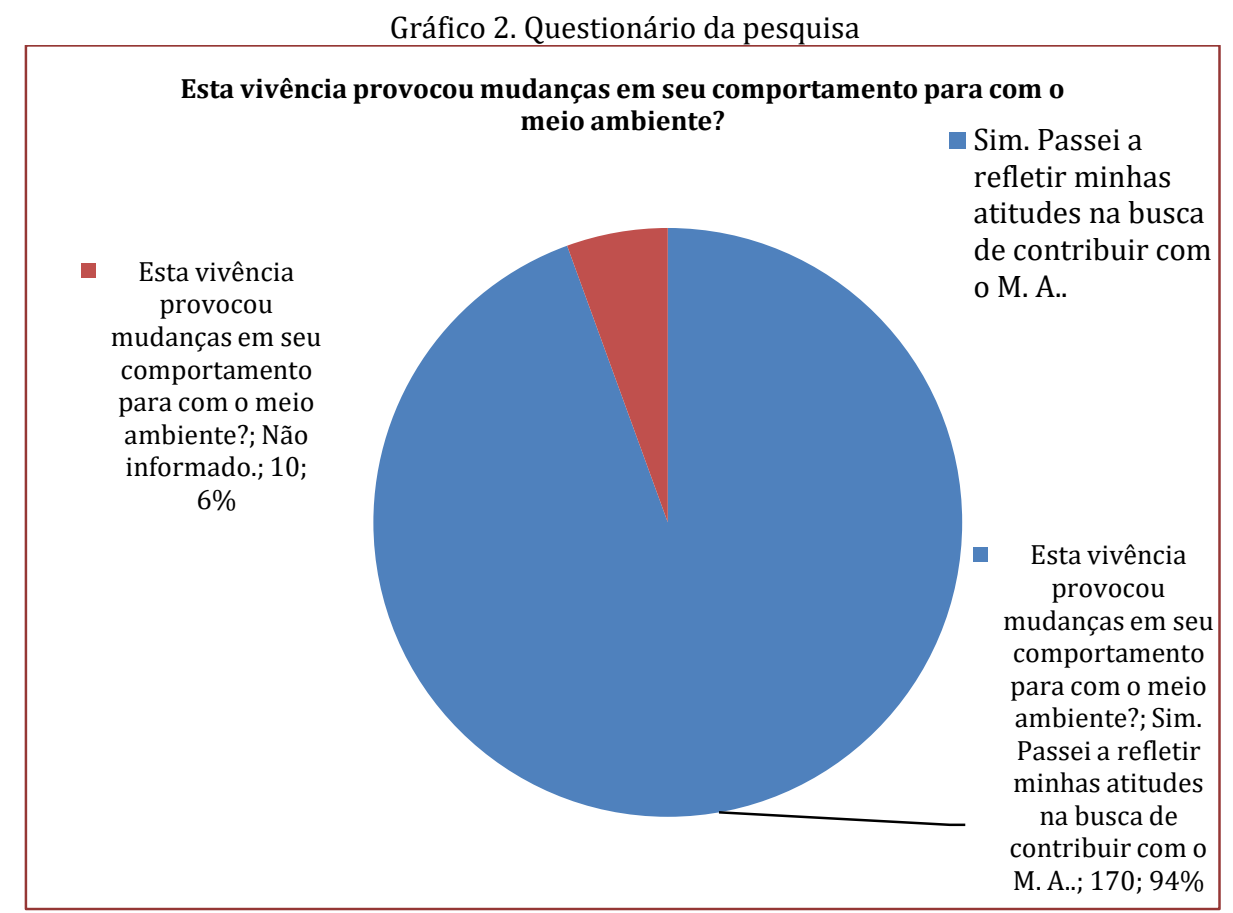

Fonte: Autores - com base nos dados coletados

De acordo com o que se pôde verificar, o lúdico quando empregado no ensino da EA, contribui significativamente para o aprendizado, tornando-o prazeroso. Este, é uma alternativa na superação aos métodos tradicionais de ensino que induzem o sentimento de aversão nos alunos pelas temáticas ambientais.

\section{CONCLUSÕES}

O objetivo central desse estudo foi alcançado com êxito, comprovou-se que o lúdico subsidia positivammmente no ensino e aprendizagem da EA. As intervençõs tiveram boa aceitação pelos alunos que, a partir das discussões sinalizaram o interesse em aplicar os conhecimentos adquiridos em situações cotidianas.

Sabe-se que nos anos iniciais do Ensino Fundamental, os estudantes estão em fase de descoberta e transformação, sendo assim, o trabalhar das questões ambientais se torna promissor, na formação de cidadãos críticos/reflexivos e compromissados para com a natureza. Mobilizações como esta são necessárias, pois enseja a criação de uma sociedade mais sustentável. 


\section{REFERÊNCIAS}

[1] ALMEIDA, P. N. de. Educação Lúdica: Técnicas e Jogos Pedagógicos. 11. ed. São Paulo: Edições Loyola, 1995.

[2] AUSUBEL, D. P.; NOVAK, J. D.; HANESIAN, H. Psicologia educacional. 2. ed. Rio de Janeiro: Interamericana, 1980. 625p.

[3] AZEVEDO, R. O. M.; NEVES, C.. O lúdico contribuindo na formação de professores da educação infantil e dos anos iniciais do ensino fundamental -Revista ARETÉ - Revista Amazônica de Ensino de Ciências- N.3 - 2009.

[4] CONDE, T. T.; LIMA, M. M.; BAY, M.. Utilização de metodologias alternativas na formação dos professores de biologia no IFRO - Campus Ariquemes. Revista Labirinto, a.13, n.18, p.139-147, 2013.

[5] DHOME, V.. Atividades lúdicas na educação: o caminho de tijolos amarelo do aprendizado. 4⿳a.. ed. Petrópolis: Vozes, 2008.

[6] DIAS, G. F.. Educação Ambiental - Princípios e Práticas. 9. ed. São Paulo: Gaia, 2004.

[7] MEDIANA, N. M.. A formação dos professores em Educação Ambiental. In: Panorama da educação ambiental no ensino fundamental/ Secretaria de Educação Fundamental - Brasília: MEC; SEF, 2001. 


\title{
Capítulo 22
}

\section{Educação ambiental: Um relato de experiência no contexto da educação religiosa}

\author{
Ana Cristina Xavier Leandro de Oliveira \\ Maria Cristina Leandro de Oliveira Neves Ferreira
}

Carlos André Lucena da Cruz.

Resumo: A Educação Ambiental - EA é considerada uma grande contribuição educacional da contemporaneidade. Vinculada à busca das possíveis soluções dos problemas ambientais e às condições dignas de vida, caracteriza-se em seu processo pedagógico como educação política por ser questionadora e inovadora quando interrelaciona as temáticas ambientais às do cotidiano. Nesse sentido, favorece possibilidades de ir além do âmbito escolar, no que tange a inclusão da temática ambiental de maneira mais específica no contexto do ensino religioso. Este trabalho tem por objetivo relatar a experiência da práxis de uma EA que complemente e valorize a dimensão espiritual. 0 incentivo para a inclusão da EA no conteúdo doutrinário, evangélico é trabalhar temas, questões e conflitos num processo de ensino-aprendizagem em forma de projeto como proposta renovadora para uma prática de ensino mais adequada e integrada à categoria infanto-juvenil. 0 desenvolvimento do novo processo metodológico supõe uma revolução na própria Instituição devendo-se levar em consideração a identidade institucional, sua comunidade e particularidades locais e regionais para elaboração de seu Projeto Político Pedagógico. Desta forma, que a dimensão básica do projeto seja a disponibilização da informação ambiental podendo desenvolver atividades diversas de EA tais como: seminários, oficinas, campanhas, passeios, numa perspectiva articuladora e integradora que propicie o desenvolvimento ético, moral, espiritual e intelectual de jovens e crianças. Este processo como um campo de experimentação deu-se na Associação Espírita Obreiros da Vida Eterna, localizada no município do Natal, no Rio Grande do Norte por meio do "Projeto Berçário: plantando a semente" que num primeiro momento demonstrou-se positivo, por conceber resultados adquiridos pelo conhecimento e conscientização de novas visões de mundo, no sentido de valores de forma comportamental. Destarte, este projeto evidencia que é possível trabalhar a EA em instituições religiosas por assim transcender o campo teórico e apresentar relato de experiência descrita. Outro aspecto que caracteriza a plenitude deste trabalho é o envolvimento e a participação da família no processo de planejamento das atividades envolvidas e, com isso, obviamente esse universo se amplia promovendo a expansão da experiência em foco e valorizando a convivência fraterna tornando-se assim, fonte de embasamento a todos os profissionais de educação.

Palavras-chave: Educação Ambiental, Educação Religiosa, Relato de Experiência. 


\section{INTRODUÇÃO}

A Educação Ambiental - EA é considerada uma grande contribuição educacional da contemporaneidade. Vinculada à busca das possíveis soluções dos problemas ambientais e às condições dignas de vida, caracteriza-se em seu processo pedagógico como educação política por ser questionadora e inovadora quando inter-relaciona as temáticas ambientais às do cotidiano.

Muitos são os problemas ambientais e todos levam a reconhecer a necessidade de refletir um modo de se conceber atitudes que possibilitem a mudança desse quadro crítico que se caminha para uma impiedosa degradação ambiental e possível desestabilização de toda espécie de vida na Terra (DUPAS, 2008).

$\mathrm{Na}$ verdade, há uma longa história dos estragos causados a saúde humana e ao meio ambiente que tem grande parte de sua origem no sistema econômico capitalista. Para conter esses intensos impactos socioambientais, foram identificadas as conferências de âmbito global fundamentadas na preservação e sustentabilidade da vida como solução viável para uma sociedade sustentável. A partir desse reconhecimento, surgem novas ideias permitindo uma inovação tecnológica como forma de diminuir a exaustão de recursos naturais.

Porém, a decisão requer um contexto de mudanças de nossos atuais pensamentos e maneira fragmentada de ver a própria vida de modo que o cuidado com a natureza passa a ser de forma comportamental, quando o sujeito também se sente protegido. Assim, surge a EA como proposta interdisciplinar do ser em que o grande desafio é os méritos de um novo pensamento e novos hábitos por assim entender que nossos atos afetam toda a existência de formas mais sutis (CAPRA, 1996).

A relevância do assunto em debate descreve uma experiência vivenciada, mas principalmente objetiva apresentar resultados perceptíveis dessa práxis, além de fortalecer o pensamento político, reflexivo, pedagógico da EA quanto à mudança de comportamento dos indivíduos estabelecendo uma aliança com a natureza, ou seja, entre nós mesmos.

De acordo com o exposto, este trabalho tem por objetivo geral relatar o contexto no qual se desenvolve as atividades do Projeto Berçário: plantando a semente na Associação Espírita Obreiros da Vida Eterna, em Natal/RN. A partir da descrição, tem-se por objetivos específicos: apresentar abordagem metodológica inserida no contexto religioso; relatar a vivência de intervenção de uma EA que complemente e valorize a dimensão espiritual.

O desenvolvimento das atividades do projeto se dá a partir da proposta de ações educativas nas áreas de meio ambiente e saúde propondo o cultivo de hortaliças, plantas frutíferas, medicinais e ornamentais e jardinagem, considerando isso, uma simultânea vivência da teoria e prática mediante temas reflexivos que se complementam na conjuntura dos ensinamentos religiosos.

O projeto articula-se a partir de planejamento, estruturação e adequação de recursos pedagógicos, humanos, físicos e financeiros de acordo com a realidade local. Tendo como público alvo as crianças da Evangelização Espírita Infantil na faixa etária entre 4 a 12 anos. Em sua característica, o projeto não tem tempo de duração pré-estabelecida, pois, trata-se de uma atividade continuada uma vez que é possível pensar em sua continuidade em novas gerações.

Destarte, este trabalho justifica-se pela importância de sua dimensão interdisciplinar que contextualiza com a transformação e a renovação da vida na medida em que as atividades proporcionam o contato com a terra, o preparo e os cuidados com as plantas, o semear, regar e ver brotar as sementes que sem dúvida é um valioso instrumento educativo.

Sendo assim, busca-se uma conexão entre a EA e a educação religiosa unindo saberes com o conhecimento experimental de forma que a aprendizagem valorize as diversas formas de conhecimento facultando a formação do ser em suas dimensões biológica, psicológica, social e espiritual.

\section{MEDOTOLOGIA}

A escolha do título do trabalho então apresentado tem como propósito argumentar a dimensão constitutiva da EA capaz de mediar à esfera religiosa sem que seja necessário um vínculo religioso. Conforme previsto no próprio projeto, a elaboração do Projeto Político Pedagógico dá-se a partir da identidade institucional, sua comunidade e particularidades culturais, locais e regionais. Por este prisma, constrói-se um espaço de convivência em torno de atividades de EA das quais participam crianças e jovens numa nova perspectiva de aprendizagem sob a égide do cristianismo, surgindo nesse contexto temas, 
questões e conflitos mediante os quais se trabalha o conteúdo doutrinário, evangélico sempre através do diálogo e do trabalho (PAROLIN, 2013).

Nesse sentido, o pretendido dessa metodologia de ensino é propor um redimensionamento da visão de evangelização tradicional que significa trazer a própria experiência da autora, tendo como fio condutor a educação pela vivência com o outro e pelo trabalho, sobre como Jesus abordou a Boa Nova na Terra (PAROLIN, 2013). Para a autora, o alcance da consciência desse processo significa a pedra angular na construção e transformação do mundo pelo equilíbrio moral e espiritual das pessoas.

Ao primeiro momento de desenvolvimento das atividades do projeto dedicou-se exclusiva atenção à defesa e a preservação do meio ambiente como prevê o ordenamento jurídico brasileiro no artigo 225 capt da Constituição Federal/1988, como sendo um direito fundamental à sadia qualidade de vida para as presentes e futuras gerações. Destacando-se os assuntos predominantes de estudo, a saber: ar, água e solo, lixo, resíduos sólidos, coleta seletiva, política dos 3R's - Reduzir, Reciclar, Reutilizar, com base na Política Nacional do Meio Ambiente - PNMA edição da Lei no 6.938/81.

Mais tarde, outras atividades foram abordadas buscando-se a possibilidade de um conhecimento conscientizado através de campanhas, seminários, visitas técnicas, estimulando o grupo a participar na construção de sua cidadania, entendendo suas responsabilidades, seus direitos e os deveres numa sociedade democrática (REIGOTA, 2009).

A realização deste projeto conta com o apoio e a mão de obra dos voluntários desde o conhecimento do local, levantamento da estrutura física, preparação do solo, adubação, preparo de canteiros, oficina de arte reciclagem, fornecimento de mudas de plantas, sementes, preparação de lanche e organização geral.

Como garantia de sua sustentabilidade, atentamos como alternativa a lucratividade da sua cadeia produtiva de venda de mudas de plantas ornamentais, condimentais e chás, dando-se também o direito de consumo para os envolvidos no processo de sua execução.

O Projeto consiste em uma organização corporativa fundamental para um bom desempenho de sua construção tais como: planejamento; aulas teóricas e práticas; abordagem de datas comemorativas tais como: dia mundial do meio ambiente, dia mundial da água, dentre outras; pesquisas, leituras, produção textual; vídeos educativos, músicas, acompanhamento e avaliação e relatório das atividades.

\section{RESULTADOS E DISCUSSÕES}

Num primeiro momento podem-se observar os resultados adquiridos pela ação-reflexão no sentido de valores atitudinais como mudança de comportamento diante de situações de preservação ambiental, interesse pelas atividades com a finalidade de evoluir na prática dessas atitudes.

\section{CONCLUSÕES}

A Educação Ambiental se insere no contexto religioso como uma complementariedade de nossas percepções e maneiras de pensar acerca da compreensão da vida, sentida e concebida, fazendo-nos refletir sobre a indissociabilidade entre a natureza e sociedade propiciando ao homem apropriação de suas ideias.

A partir deste ponto de vista, o projeto justapõe-se a luz da educação sendo isto um processo de caráter sistemático e flexível, proporcionando oportunidades didáticas para que a aprendizagem ocorra pela compreensão. Pois, bem sabemos que a transformação das relações com o meio ambiente dar-se pela construção de valores sociais, despertando um sentimento de responsabilidades imediatas para atenuar os problemas ambientais.

É importante destacar que a EA nos possibilita trabalhar em quaisquer denominações religiosa e nos mais diversos espaços de aprendizado, pois a aplicação de sua metodologia é de baixo custo tornando realizável o seu trabalho estimulando a concepção de se pensar e praticar a educação contemporânea (REIGOTA, 2009).

Ao final, ressalta-se que a experiência é reconfortante. Outro aspecto que caracteriza a plenitude desse trabalho é o envolvimento e a participação da família no processo de planejamento das atividades envolvidas e, com isso, obviamente esse universo se amplia promovendo a expansão da experiência em foco e valorizando a convivência fraterna tornando-se assim, fonte de embasamento a todos os profissionais de educação. 


\section{REFERÊNCIAS}

[1] BRASIL. Lei no 6.938 de 31 de agosto de 1981. Dispõe sobre a Política Nacional do meio Ambiente, seus fins e mecanismos de formulação e aplicação, e dá outras providências - disponível em <http://www.planalto.gov.br>, acesso em 12/08/2016.

[2] CAPRA, Fritjof. A Teia da Vida: Uma nova compreensão científica dos seres vivos. São Paulo: Editora Cultrix, 1996.

[3] DUPAS, Gilberto (org.). Meio Ambiente e crescimento econômico: tensões estruturais. São Paulo: Editora UNESP, 2008.

[4] REIGOTA, Marcos. 0 que é educação ambiental. 2 ed. São Paulo: Brasiliense, 2009. Coleção primeiros passos; 292.

[5] PAROLIN, SONIA REGINA HIERRO (Org.), 1958 - Conviver para amar e servir: fundamentação Espírita sobre a metodologia do espaço de convivência, criatividade e educação pelo trabalho no serviço assistencial espírita - 1. Ed. 1. Imp. - Brasília: FEB, 2013. 


\section{Capítulo 23}

Conhecendo a percepção ambiental de estudantes do Ensino Fundamental II, através de desenhos em turmas de $8^{\circ}$ e $9^{\circ}-$ anos

Ana Katarina Nascimento de Azevedo

Maria de Fátima Camarotti

Resumo: A Educação Ambiental (EA) promove a união entre pessoas e o ambiente, criando vínculos entre a identidade, a cultura local e a natureza. Sobre este tema muitos estudiosos têm descoberto que estudantes de Ensino Fundamental (EF) podem expressar a percepção ambiental sobre o meio ambiente através de desenhos ou imagens, assim esta pesquisa teve como objetivo analisar qual a visão de mundo e de meio ambiente os estudantes do Ensino Fundamental, dos $8^{\circ}$ e $9^{\circ}$ anos das Escolas, EE Jerônimo Gueiros e EM Veríssimo de Melo têm. Analisou-se 77 desenhos, durante o mês de novembro de 2019. 0 estudo revelou que na EE Jerônimo Gueiros, 22 estudantes do $9^{\circ}$ ano demonstraram ter a percepção naturalista e 26 estudantes, a percepção socioambiental. Já 14 desenhos, dos estudantes da EM Veríssimo de Melo do $8^{\circ}$ ano, categorizaram como naturalista e 15 como oócioambiental. Num segundo momento, os mesmos desenhos, foram analisados sobre outras categorias e revelou-se que os do 9o ano da EE Jerônimo Gueiros, 20 estudantes percebiam o meio ambiente como um problema a ser resolvido, e, na EM Veríssimo de Melo, 12 estudantes apresentaram a visão natureza. Conclui-se que o estudo permitiu aos estudantes se envolver ativamente nas atividades propostas e com esta ação refletirem sobre sua postura na atuação sobre o meio ambiente.

Palavras-chave: Meio ambiente. Categorias. Aprendizagem. 


\section{INTRODUÇÃO}

O estudo sobre o meio ambiente é tema da disciplina de Ciências, quando se trata de Ensino Fundamental (EF) e Biologia, quando se trata de Ensino Médio, sendo também considerado um componente curricular transversal devendo ser estudado sobre a ótica da Educação Ambiental (EA) através de ações interdisciplinares. A EA promove a união entre pessoas e o ambiente, criando vínculos entre a identidade, a cultura local e a natureza. É uma temática que pode também vir tratada em Ciência, Tecnologia, Sociedade e Ambiente (CTSA). Pode-se destacar que desenvolver a ciência através da pesquisa, na perspectiva CTSA, torna-se uma ferramenta incentivadora, haja vista que todas as atividades, durante as intervenções, fazem com que os estudantes evoluam na compreensão dos objetivos de conhecimentos abordados pelos professores (SILVA; ARAUJO, 2012).

A percepção ambiental visa compreender como as pessoas visualizam o mundo, adquirem seus conceitos, valores, e, a partir destas, reagem com ações relativas ao meio ambiente e tornam-se sensibilizados perante a crise socioambiental (OLIVEIRA; CORONA, 2008).

Neste sentido estudos e pesquisas vêm sendo realizados com os estudantes com o uso de imagens e desenhos, tais como em Tamaio (2002) e Carvalho e Nunes(2014) demostrando que estas podem ser utilizadas para averiguar a percepção dos estudantes sobre o meio ambiente.

O estudo sobre o meio ambiente a partir de desenhos é uma temática recorrente e pesquisas com esta fonte de dados, pretende avaliar e demonstrar que atividades lúdicas podem ser instrumentos avaliativos interessantes e reveladores sobre como a sociedade está organizada em relação à temática, permitindo num futuro implementar inclusive políticas públicas que melhorem o aprendizado dos estudantes para a gestão dos recursos naturais.

Em seus estudos Tamaio (2002) definiu categorias para a análise de desenhos voltados para o conceito sobre a natureza, são eles: Romântica, utilitarista, científica, generalizante, naturalista e sócioambiental, destacando-se assim a ideia de que os estudos sobre o ambiente são importantes e podem ser realizados em qualquer nível de ensino seja do EF ao Ensino Médio.

Na categoria Romântica tem-se uma visão otimista da natureza com a ausência total da atuação humana, na categoria Utilitarista tem-se a visão de que a natureza são os recursos naturais como água, solo, ar entre outros, na categoria Científica há a descrição de uma natureza sistêmica com a observação de que tudo se encaixa, na categoria Generalizante vê-se a natureza como uma ideia simples, vaga e abstrata; na categoria Naturalista, a natureza não sofreu a ação transformadora do homem, e na categoria sócioambiental percebe-se a atuação transformadora do homem, geralmente demonstrando que suas ações são responsáveis pela degradação do meio ambiente.

O mesmo aspecto também relatado por Carvalho e Nunes (2014) que adaptou a Matriz de Representação Ambiental criada por Sauvé e conseguiu enquadrar as ilustrações feitas pelos estudantes em uma das categorias descritas: a) natureza (categoria um), b) recursos (categoria dois), c) problemas (categoria três), d) sistemas (categoria quatro), e) meio de vida (categoria cinco), f) biosfera (categoria seis) e g) projeto comunitário (categoria sete).

Na categoria Natureza deve-se observar nos desenhos somente uma natureza contemplativa e na qual não há a atuação do homem, na categoria Recursos deve-se observar a gestão dos recursos naturais, na categoria Problemas os desenhos abordam as ações de degradação do homem, na categoria Sistemas observa-se se o estudante apontou em seus desenhos, soluções para minimizar as ações de degradação ambiental, na categoria Meio de vida observa-se se o estudante expressou saber conhecer e organizar sua vida sem interferir na natureza, na categoria Biosfera procura-se verificar se o estudante expressou saber viver junto a longo prazo e na categoria Projeto comunitário verifica-se se o estudante além de saber conviver, apresenta comprometimento com a preservação do meio ambiente.

A presente pesquisa teve como objetivos analisar a visão de mundo e do meio ambiente dos estudantes do EF e refletir sobre sua atuação no mundo.

\section{PERCURSO METODOLÓGICO}

Esta pesquisa teve como pressupostos metodológicos a abordagem qualitativa, portanto, a pesquisa qualitativa tem o pesquisador como participante ativo no local de estudo e o envolvimento com os atores sociais, estabelecendo harmonia e credibilidade, sendo fundamentalmente interpretativa, isto é, inclui a 
análise dos dados e a interpretação para identificar temas e/ou categorias (RICHARDSON; PFEIFFER, 2017).

É considerada qualitativa pois utilizou-se de material produzidos pelos estudantes como a construção de desenhos com a temática do meio ambiente e por tratar-se de desenhos a análise é única, não sendo importante a quantidade de desenhos elaborados e sim a qualidade do desenho no sentido de demonstrar a percepção ambiental (tema subjetivo) dos estudantes.

Não há expectativa de que a percepção dos estudantes seja certa ou errada. Pretende-se avaliar como esta percepção ambiental é demonstrada em seu contexto histórico, social e ambiental. Trata-se também de uma pesquisa bibliográfica pois as autoras buscaram fontes bibliográficas para referenciar e estudar a percepção ambiental dos estudantes do EF II sobre a questão do meio ambiente.

A coleta de dados foi feita através dos desenhos dos estudantes antes da aplicação dos conteúdos sobre meio ambiente previstos para as turmas de 8o e 9o ano do Ensino Fundamental conforme a BNCC (BRASIL, 2017).

Considerou-se para este estudo as categorias de análise sobre o conceito de natureza elaborada por Tamaio e a Matriz de representação ambiental criada por Sauvé (2005) e adaptada por Carvalho e Nunes (2014).

O estudo foi realizado em duas escolas públicas sendo uma Estadual (Escola Estadual Jerônimo Gueiros EE Jerônimo Gueiros) e uma Municipal (Escola Municipal Veríssimo de Melo - EM Veríssimo de Melo). Participaram da pesquisa 77 estudantes distribuídos em duas turmas, na escola EE Jerônimo Gueiros os participantes (48 no total) eram do $9^{\circ}$ ano do EF e na EM Verissimo de Melo eram do $8^{\circ}$ ano, sendo 29 estudantes.

\section{RESULTADOS E DISCUSSÃO}

Num primeiro momento os estudantes elaboraram desenhos respondendo a questão: Qual a imagem que eles tinham sobre o meio ambiente ? Em seguida estes desenhos foram analisados e categorizados segundo Tamaio (2002) em duas categorias: Naturalista e Socioambiental, com 22 estudantes da EE Jeronimo Gueiros ( $9^{\circ}$ ano) demostrando ter a percepção naturalista e 26 estudantes a percepção socioambiental. (Figuras 01 e 02). Já para a EM Veríssimo de Melo ( $8^{\circ}$ ano) 14 desenhos foram categorizados como naturalista e 15 como socioambiental (Figura 03).

Figura 01 - Desenho produzido pelo estudante do 9o ano do Ensino Fundamental da Escola EE Jerônimo Gueiros representando a categoria sócioambiental proposta por Tamaio (2002).

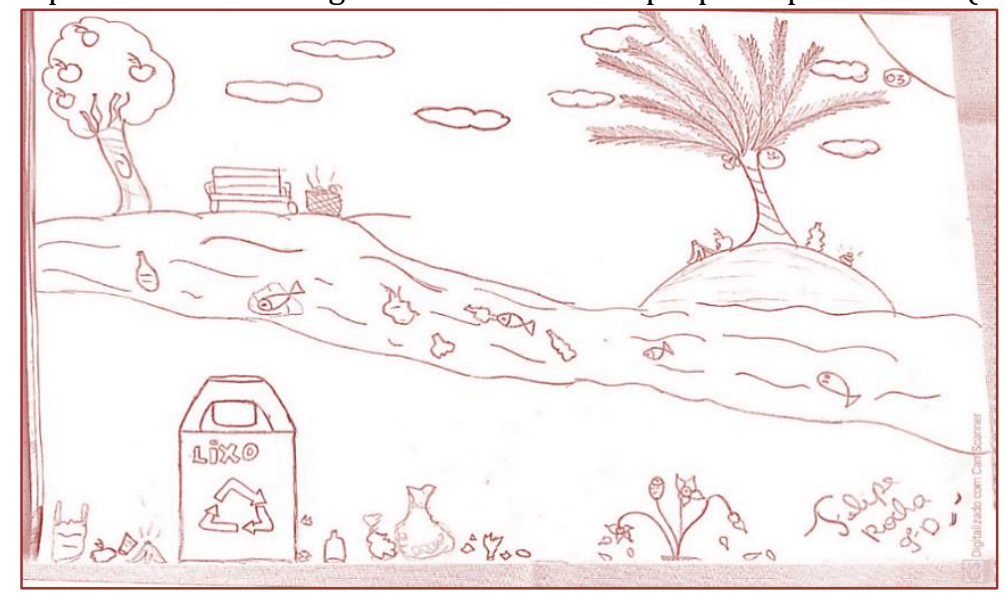


Figura 02 - Desenho produzido pelo estudante do 9o ano do Ensino Fundamental da Escola EE Jerônimo Gueiros representando a categoria sócioambiental proposta por Tamaio (2002).

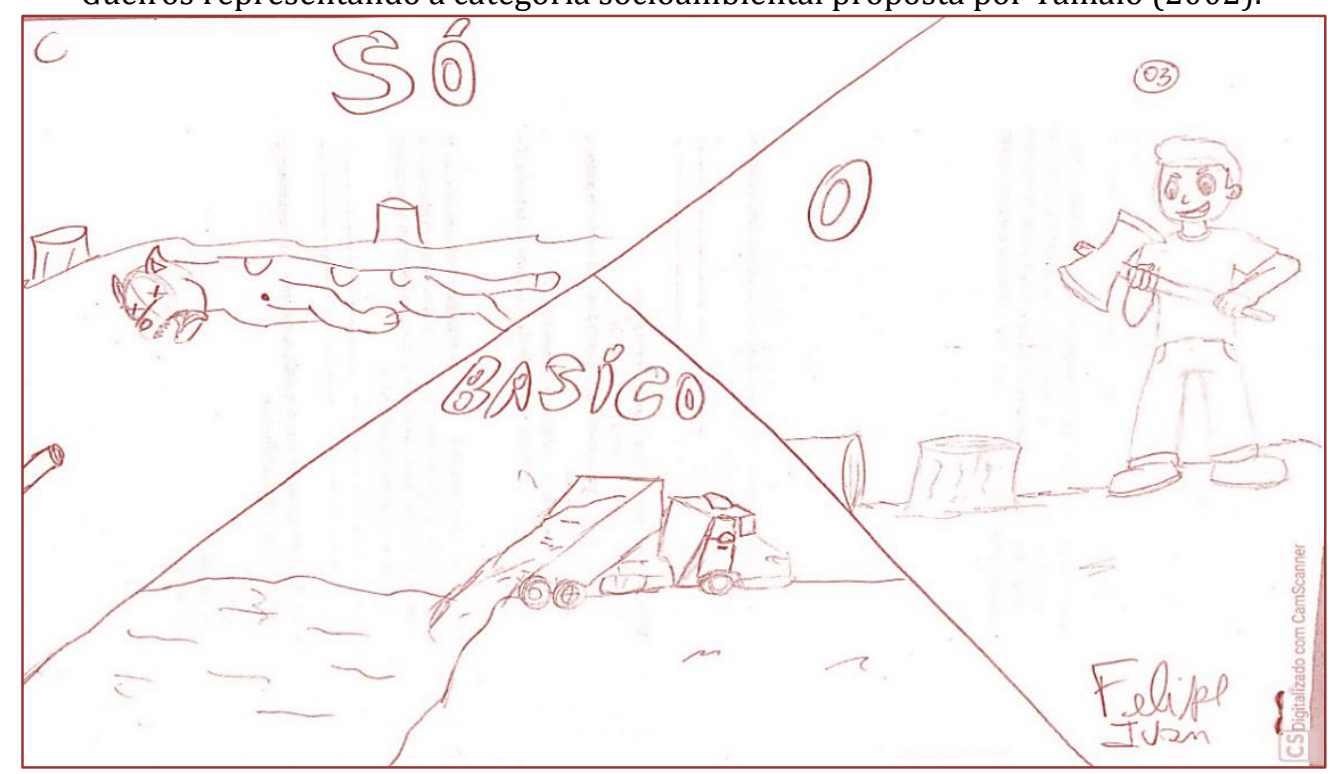

Figura 03 - Desenho produzido pelo estudante do $8^{\circ}$ ano do Ensino Fundamental da Escola EE Verissimo de Melo representando a categoria sócioambiental proposta por Tamaio (2002).

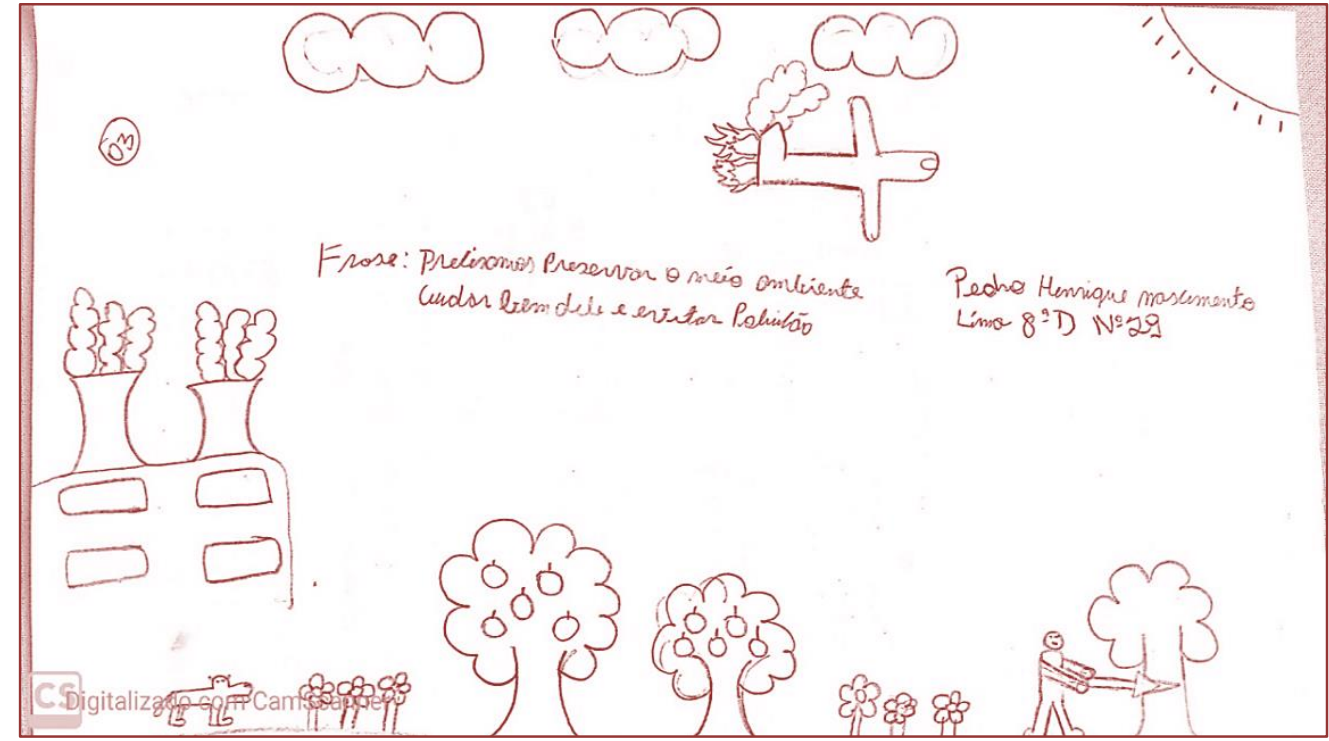

Vale destacar, que os conceitos relacionados ao contexto socioambiental apresentados pelos estudantes são, segundo Tamaio (2002), fruto de um processo de interação e entrelaçados a diversos níveis de aprendizagem e o mesmo autor ressalta que esses conceitos não se constroem de forma linear, eles são históricos, formulados e reformulados no curso e no processo da aprendizagem.

Num segundo momento estes mesmos desenhos foram estudados e categorizados sobre o ponto de vista de Carvalho e Nunes (2014) sendo analisados e classificados os desenhos dos estudantes do 9o ano: 15 foram categorizados segundo a categoria Natureza e 20 na categoria Problemas (Figura 04), dois na categoria sistemas, nove na categoria biosfera e dois na categoria Projeto comunitário. 
Figura 04 - Representação do estudante do 9o ano para o problema do Desmatamento, o que caracteriza a categoria problemas proposta por Carvalho e Nunes (2014).

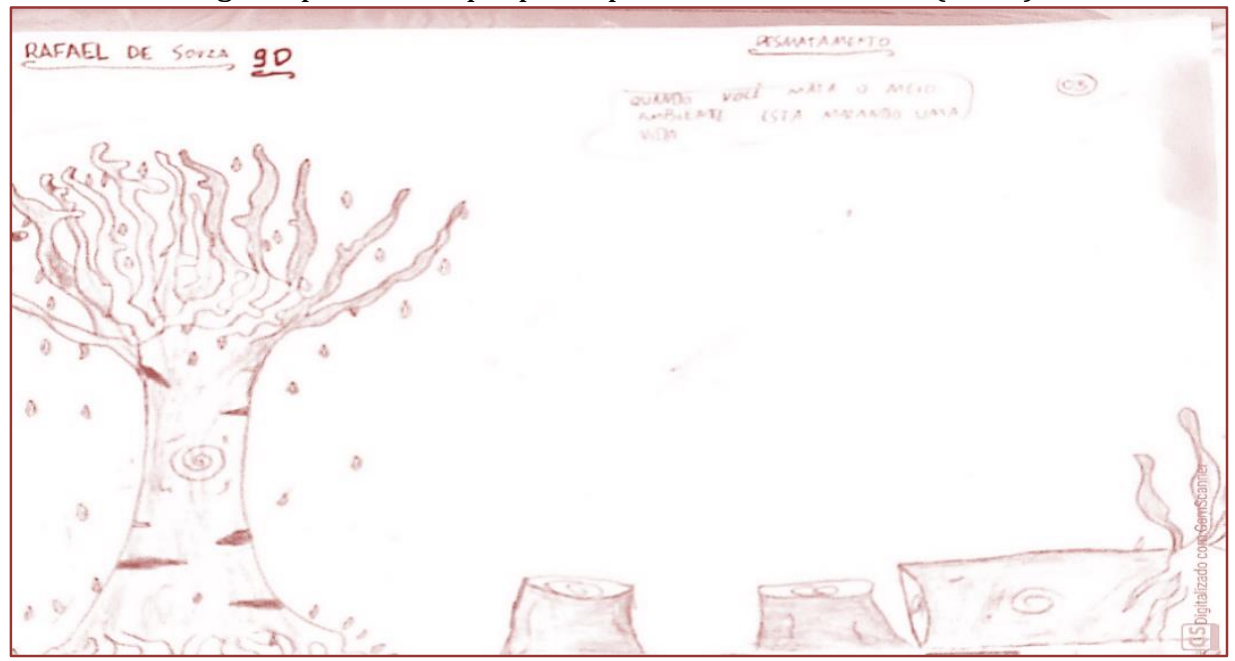

Já para o $8^{\circ}$ ano teve 12 estudantes na categoria Natureza (Figura 05), 11 estudantes na categoria Problemas, quatro estudantes na categoria Meio de vida, um estudante na categoria Biosfera e um estudante na categoria Projeto de vida.

Percebe-se neste estudo pelas análises de Tamaio (2002) e de Carvalho e Nunes (2014) que o perfil dos estudantes da rede pública sejam eles da rede estadual ou municipal, apresentam uma percepção ambiental voltada para os questionamentos sobre a influência do homem sobre o meio ambiente, sendo esta influência negativa, o que gera muitos dos problemas relatados nas imagens tais como: desmatamento, descarte inadequados de resíduos sólidos, queimadas e como retratado em algumas imagens, derrames de óleo em regiões de praias.

Figura 05 - Representação do estudante do $8^{\circ}$ ano que caracteriza a categoria Natureza proposta por Carvalho e Nunes (2014).

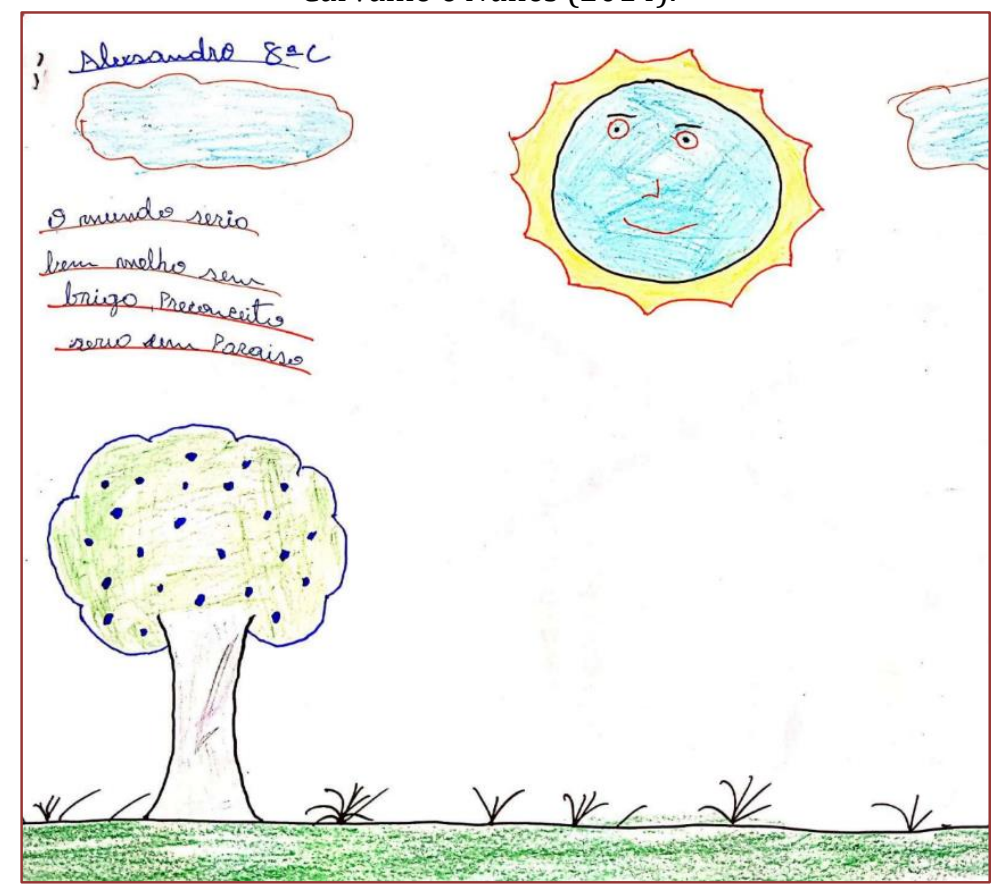


Percebe-se que o desmatamento, queimadas e os derramamentos de óleo em regiões de praias demonstram o quanto os estudantes são influenciados pela mídia já que foram assuntos recorrentes nos telejornais durante a pesquisa no segundo semestre de 2019.

Estes resultados também foram observados na pesquisa desenvolvida por Aguiar e Pereira (2016), com um público de faixa etária entre 11 e 17 anos. Nesta pesquisa os autores identificaram dois grupos de representação da relação homem e natureza, através de desenhos. 0 primeiro grupo apresentava uma relação do homem com a natureza baseada num conflito entre o natural e o artificial o que ficou expresso nos desenhos a partir das práticas dos seres humanos que ocasionam alterações ao meio ambiente, de modo prejudicial. Aguiar e Pereira afirmam que, "para esses estudantes, a presença do homem acaba gerando impactos negativos ao meio ambiente" (2016, p.1). Observa-se estas visões também nos desenhos elaborados pelos estudantes participantes da pesquisa nas Escolas em Natal/RN (Figuras 06 e 07).

Figura 06 - Desenho produzido pelo estudante do 8o ano do Ensino Fundamental da Escola EE Verissimo de Melo representando a categoria sócioambiental proposta por Tamaio (2002).

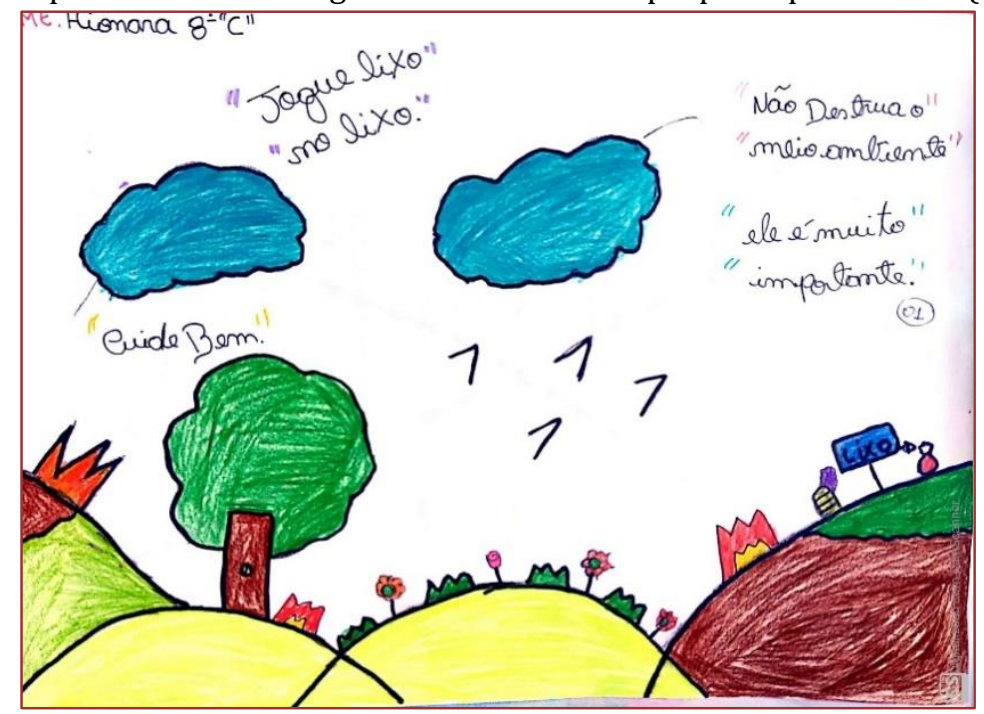

Figura 07 - Desenho produzido pelo estudante do 8o ano do Ensino Fundamental da Escola Estadual Jerônimo Gueiros representando a categoria sócioambiental.

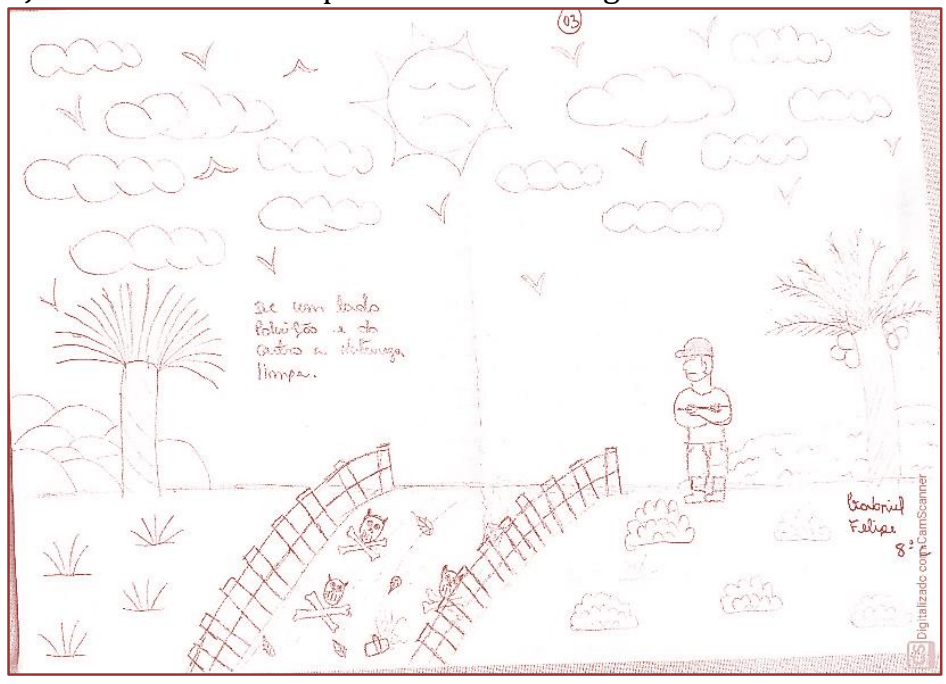


Neste aspecto Santos e colaboradores "defendem que é necessária uma mudança nas formas de agir e pensar as questões e inter-relações socioambientais" (SANTOS et al., 2017, p. 173). Demostrando que "indivíduos que possuem a percepção de sustentabilidade apresentam uma sensibilidade nítida a respeito da busca de uma relação de equidade entre natureza, ambiente e homem" (SANTOS et al., 2017, p. 173).

Percebe-se com esta atividade que é possivel trabalhar a Educação Ambiental numa pespectiva holistica, desvendando e desbravando conceitos chaves de diversas disiciplinas tais como: ciencias, artes, geografia e português.

Também pode-se trabalhar não só no Fundamental II como também no Fundamental I e no Ensino Médio, fazendo com que os alunos venham a ser sensibilizados para sua atuação no ambiente e desta forma possam adquirir hábitos saudáveis em relação a saúde pessoal e coletiva, contribuindo para a preservação da comunidade local e desta forma atuando localmente para então perceber que sua atuação tem reflexo globalmente.

\section{CONSIDERAÇõES FINAIS}

Esta pesquisa foi elaborada e estruturada para apresentar uma análise sobre a percepção dos estudantes do Ensino Fundamental sobre o meio ambiente, tendo sido verificado que os estudantes apresentam uma visão sócioambiental o que foi considerado um avanço para o crescimento e desenvolvimento da sociedade voltada para um desenvolvimento sustentável, contribuindo assim para preservação e/ou conservação do meio ambiente.

Assim, verificou-se que ao se envolver ativamente nas atividades propostas, os estudantes passam a ser o centro da aprendizagem e com esta ação, refletem e assumem postura no sentido de construir seu próprio aprendizado e tal fato os levam a refletir de maneira mais ativa na elaboração de soluções que venham a contribuir para amenizar os efeitos da atuação humana sobre o meio ambiente.

Deve-se sempre ter em mente que os estudantes ao rfletirem sobre o meio ambiente podem desenvolver habilidades e saberes que promovem o bem estar coletivo e assim promovem o desenvolvimento Sustentável de forma mais concreta para a humanidade.

\section{AGRADECIMENTOS}

Agradeço a Prof ${ }^{a}$ Dra. Maria de Fátima Camarotti pelos valiosos ensinamentos na construção deste artigo e aos meus alunos pela dedicação em sala de aula na construção dos desenhos e aos meus familiares (esposo e pais) pela compreensão e carinho.

\section{REFERÊNCIAS}

[1] AGUIAR, R.C.; PEREIRA, C.M.R.B. A educação ambiental em oficinas pedagógicas: reflexões a partir de desenhos. Disponível em: http://www.revistaea.org/artigo.php?idartigo=1970. Acesso em: 26 nov. 2020.

[2] BRASIL. Base Nacional Comum Curricular (BNCC). Disponível em: basenacionalcomum.mec.gov.br/imagens/BNCC_EI_EF_110518_versão final 2018. Acesso em: 08 fev. 2020.

[3] CARVAlHo, M. M.; NUNES, J. R. S. Conhecimento Ambiental dos estudantes do Ensino Médio da Escola Estadual vereador Ramon Sanches Marques do Município de Tangará da Serra - MT. Revista Eletrônica Mestrado em Educação Ambiental, E-ISSN 1517-1256, v. 31, n. 2, p. 22-38, jul./dez., 2014 Disponível em: https://periodicos.furg.br/ remea/ article /view/4590. Acesso em: 01 nov. 2019.

[4] OLIVEIRA, K. A. de; CORONA, H. M. P. A percepção ambiental como ferramenta de propostas educativas e de políticas ambientais. Revista Científica ANAP Brasil, julho 2008, p.53 - 72.

[5] RICHARDSON, R. J.; PFEIFFER, D. K. Pesquisa Social: métodos e técnicas. 4. ed. rev., atual. e ampl. São Paulo: Atlas, 2017.

[6] SANTOS, F. A. S.; ECKERT N. O. S.; OLIVEIRA R. S.; NETO, H. G. S.; TEIXEIRA, L. N.; COELHO, A. S. Percepção ambiental e análise de desenhos: prática em curso de extensão universitária. Disponível em: https://pdfs.semanticscholar.org/92e8/4b118287548e7a004f2e79b2d1953a853fa0.pdf Acesso em: 26 nov. 2020.

[7] SAUVÉ, L. Educação Ambiental: possibilidades e limitações. Educação e Pesquisa, São Paulo, v. 31, n. 2, p. 317-322, maio/ago. 2005. 
[8] SILVA, P. A. V. B.; ARAÚJO, M. S. T. de. Abordagem de temas de educação ambiental sob o enfoque CTSA no ensino médio no município de Barueri-SP. SEMINÁRIO HISPANO BRASILEIRO - CTS, 2., Anais [...], p.431-443, 2012.

[9] SOUZA, C. T; VIVEIRO, A. A; Educação Ambiental e Arte: percepção ambiental infantil por meio de desenhos. ENCONTRO NACIONAL DE PESQUISA EM EDUCAÇÃO EM CIÊNCIAS. 11., Universidade Federal de Santa Catarina, Florianópolis, 2017. Disponível em: http://www.abrapecnet.org.br/enpec/xi-enpec/anais/resumos/R2532-1.pdf. Acesso em: 12 ago. 2020.

[10] TAMAIO, I. O Professor na Construção do conceito de natureza: uma experiência de Educação Ambiental. São Paulo, Annablumme, 2002, 157p. 


\section{Capítulo 24}

Ilha Interdisciplinar de Racionalidade em torno da sustentabilidade como alternativa na preservação do planeta

\section{Tatiane Evangelista Zils}

Ana Paula Magagnin Przyvara

Danislei Bertoni

Awdry Feisser Miquelin

Igor de Paiva Affonso

Resumo: 0 presente artigo apresenta a construção de uma Ilha Interdisciplinar de Racionalidade (IIR), fundamentada em Gerard Fourez, abordando uma proposta de sustentabilidade com crianças da Educação Infantil, partindo da situação clichê "Eu sou amigo do meio ambiente?". 0 projeto foi desenvolvido no CMEI Professora Julia Ribas Ferreira Araújo, localizado no município de Palmas - PR, totalizando 12 alunos do pré II. 0 projeto foi realizado em cima das oito etapas propostas na IIR, integrando professores de diferentes disciplinas, abordando questões próprias da Ciência e envolvendo as relações sociais presentes no seu cotidiano. Os resultados do projeto se mostraram positivos demonstrando que o ensino proposto de uma maneira integrada conduz a uma construção do conhecimento autônoma, despertando maior interesse e promovendo uma aprendizagem significativa por parte dos alunos. Este projeto também teve a participação da comunidade por meio de um bazar solidário realizado pelas crianças com o intuito de promover a consciência do que não serve para mim, pode ser útil para o outro.

Palavras-chave: Ilhas de racionalidade, Sustentabilidade, Interdisciplinaridade, Ensino de ciências. 


\section{INTRODUÇÃO}

Nas aulas de Ciências bem como em outras disciplinas, os conteúdos são ministrados de maneira meramente científica, não condizendo com a realidade vivenciada pelos alunos, levando muitas vezes a falta de interesse dos mesmos. Por esse motivo, se faz importante um trabalho voltado ao cotidiano do aluno, fazendo refletir e se tornar crítico perante as situações envolvidas. A interdisciplinaridade é uma ferramenta na busca de recontextualização e desfragmentação dos conteúdos.

Baseado nos contextos de Hodson (1992), as argumentações que venham escolher a prática real de transformação da realidade em questão à atividade teórica, trazendo por meio desta a defesa de uma causa ou da transformação da sociedade por meio da execução, podendo assim auxiliar e apoiar os alunos na compreensão de temas, incluindo a exploração de contexto sociopolítico, solucionar conflitos de interesse, edificar um ajuste de tomar a ação sociopolítica correta, tanto individualmente quanto coletivamente. Não se deve apenas mudar a conduta como também se deve atuar com medidas para a mudança de comportamento dos outros. $\mathrm{O}$ ativismo é a forma de transformação da realidade por meio da ação prática

A Ilha Interdisciplinar de Racionalidade (IIR) é uma metodologia de ensino proposta por Gérard Fourez, diante da perspectiva de Alfabetização Científica e Tecnológica - ACT. Segundo o autor essa metodologia favorece o desenvolvimento da autonomia dos estudantes e afirma que: "Uma pessoa que é capaz de representar situações específicas, poderá tomar decisões razoáveis e racionais contra uma série de situações problemas" (FOUREZ, 1997, p. 61).

Segundo esse autor, a Alfabetização Científica é desenvolvida por meio de objetivos humanísticos, sociais e econômicos. Os objetivos humanísticos necessitam de capacidades para situar-se em um mundo técnicocientífico, podendo assim utilizar-se destes conhecimentos para fazer a leitura do mundo atual. Os objetivos sociais implicam na diminuição das desigualdades, gerando assim, a autonomia e a criticidade diante de fatores sociais entre os indivíduos de uma mesma sociedade. Os objetivos econômicos e políticos estão ligados à participação efetiva do cidadão no desenvolvimento do potencial tecnológico e econômico do mundo (FOUREZ, 2003, p. 113).

O projeto foi desenvolvido por professoras das disciplinas de Ciências, trazendo a sustentabilidade como alternativa para salvar o planeta, desenvolvendo esta consciência em alunos do pré II, partindo da questão "Eu sou amigo do meio ambiente?", com objetivo de transcender os limites da disciplina, proporcionando interação e construção dos saberes de forma autônoma e contextualizada.

\section{FUNDAMENTAÇÃO TEÓRICA}

\subsection{ATIVISMO}

O conhecimento e experiência atuais informam e determinam a execução da atividade e, ao mesmo tempo, o envolvimento em ações e reflexão crítica. A probabilidade de os alunos se tornarem cidadãos ativos no futuro é substancialmente aumentada se os encorajarmos a agir agora, no presente, fornecendo-lhes oportunidades para que o façam, e exemplos detalhados de ações bem-sucedidas e de intervenções levadas a cabo por outros (HODSON, 1992).

Os alunos podem receber experiência de ação e, assim, aprender por meio da ação e da aprendizagem em três fases, a saber: (1) Modelagem - o professor prova e explica o comportamento desejado e fornece exemplos ilustrativos; (2) Prática guiada - os alunos efetuam tarefa essencial dentro de uma ação geral com a ajuda e auxilio do professor; (3) A aprendizagem como exercício assistido deve permitir aos alunos, além do que aprenderem a utilizar os seus conhecimentos e competências formas de abordar diferentes temas, solucionar novos problemas e construir nova compreensão. Portanto, ao lado das verificações modeladas, devem lidar através de um programa cuidadosamente sequenciado de exercícios, que o papel do professor é atuar com método de aprendizagem, facilitador e crítico (HODSON, 1992).

\subsection{ILHA INTERDISCIPLINAR DE RACIONALIDADE (IIR)}

A IIR é uma metodologia de ensino voltado para a Alfabetização Científica e Tecnológica proposta por Gérard Fourez, que tem como objetivo a formação de estudantes críticos, autônomos e que saibam negociar diante de situações que demandam atuação incisiva na sociedade perante a sua realidade. A IIR é uma metodologia que conduz o trabalho a ser desenvolvido, uma vez que a definição das ações presentes 
na atividade não deve ser determinada pelas diversas disciplinas vinculadas ao tema, porém pelo projeto, a finalidade e o contexto (PIETROCOLA, 1999).

A construção de uma IIR parte de uma situação-problema que deve estar inserida no cotidiano do aluno, e o objetivo é dar significado ao ensino aprendido nas escolas, envolvendo um contexto que ultrapassem os domínios disciplinares e direciona a uma conclusão do projeto, elaborando um produto final (BETTANIN, 2003)

Na sequência, apresenta-se a descrição das etapas da IIR e a análise:

Etapa 1 - Elaboração de Clichê da situação estudada: esta etapa também é conhecida como brainstorming ou "tempestade de ideias" que se inicia depois que a situação problema é apresentada, nada mais é do que questionamento de um grupo. Os alunos expõem questões sobre a situação, por meio de conhecimentos prévios sobre o assunto, podendo estabelecer suas próprias hipóteses e ideias iniciais, os questionamentos podem conceber pensamentos corretos ou errados a respeito da situação estudada, uma vez que este é o primeiro contato oficial sobre o projeto.

Etapa 2 - Panorama espontâneo: esta etapa pode complementar a primeira etapa, ampliando a situação clichê, é feito o levantamento dos principais fatores que contribuem no desenvolvimento da IIR. As caixaspretas a serem abertas ocorrem nesta fase, onde os participantes ainda desconhecem alguns conhecimentos, podem ocorrer também opções de alguns caminhos para resolver o problema, neste momento se tem o envolvimento dos especialistas e suas especialidades em diferentes áreas de conhecimento relacionadas ao tema. Todas essas ações contribuem na orientação das escolhas diante do que se pretende com o projeto, auxiliando no desenvolvimento dos objetivos da metodologia.

Etapa 3 - Consulta aos especialistas: neste momento ocorre a escolha e consulta dos especialistas estabelecidos na etapa anterior. Estes possuem domínio sobre determinado assunto que será abordado, podendo ser um profissional vindo do ambiente fora do escolar ou mesmo professores, alunos e outras pessoas dentro do ambiente escolar. Esta consulta pode ser realizada por meio de entrevistas, palestras sobre o tema e conversas durante as aulas, porém a mesma deve esclarecer às dúvidas e aos pontos considerados importantes, contribuindo com novos conhecimentos aos grupos de alunos que estão participando da IIR.

Etapa 4 - Indo à prática: nesta fase acontece uma aproximação com o dia-a-dia, ocorre neste momento o encontro com a prática, podendo ocorrer visitas técnicas em locais relacionados ao tema, como praças, empresas, bibliotecas, realização de experimentos, leituras, saídas de estudo, relacionando teoria e prática, aprofundando o conhecimento dos alunos.

Etapa 5 - Abertura de caixas-pretas com a ajuda de especialistas: nesta etapa ocorre o encontro interdisciplinar do assunto abordado, abrindo as caixas-pretas relacionadas às disciplinas específicas envolvidas no projeto. Os conhecimentos são estudados e debatidos mais profundamente sob a perspectiva das diferentes disciplinas envolvidas.

Etapa 6 - Esquema global da situação estudada: nesta etapa ocorre uma síntese ou um esquema geral da IIR, contendo as anotações parciais de todas as atividades realizadas até o momento, podendo ser desenvolvidas por meio de resumo, figuras e esquemas, vídeos, desenhos, cartazes, entre outras, demonstrando todo o trabalho percorrido até o momento.

Etapa 7 - Abertura de caixas-pretas sem a ajuda de especialistas: nesta etapa os estudantes ganham autonomia para a resolução das questões da IIR, algumas vezes necessitam buscar informações complementares, tendo mais abertura com o grupo. Nesta fase não tem a ajuda de especialistas da área, é valorizada as discussões entre os estudantes participantes para complementação das informações.

Etapa 8 - Síntese da IIR produzida: nesta etapa é sintetizado todo o desenvolvimento do trabalho ocorrendo então uma representação concreta do que foi aprendido pelos alunos no desenvolvimento da IIR. É a síntese da IIR, que deve levar a resposta à situação-problema inicial, este processo pode ocorrer por forma oral ou escrita, e com a criação de um produto final elaborado pelos estudantes.

\subsection{SUSTENTABILIDADE}

É preciso ter clareza de que uma educação voltada à sustentabilidade deve contemplar como tema central o respeito, este respeito deve ser com o meio ambiente que estamos inseridos, com o próximo, principalmente com as gerações futuras que também irão depender dos recursos naturais. 0 caminho é 
tornar a educação ambiental um processo estratégico para a sustentabilidade, fazendo uma conexão entre ética e educação ambiental (GRÜN, 2007).

Neste contexto podemos observar a descrição de Unesco, (2005).

a) valorização do papel fundamental que a Educação e a aprendizagem desempenham na busca comum do Desenvolvimento Sustentável. b) disseminação dos contatos, com a criação de redes, o intercâmbio e a interação entre as partes envolvidas no programa Educação para o Desenvolvimento Sustentável; c) fornecimento do espaço e as oportunidades para aperfeiçoar e promover o conceito de Desenvolvimento Sustentável e a transição a ele - por meio de todas as formas de aprendizagem e de sensibilização dos cidadãos; d) fomento à melhoria da qualidade do ensino e da aprendizagem no âmbito da educação para o Desenvolvimento Sustentável; e) desenvolvimento de estratégias em todos os níveis, visando fortalecer capacidades no que se refere à Educação Desenvolvimento Sustentável (UNESCO, 2005).

Portanto, se deve voltar à uma educação para a sustentabilidade e o consumo consciente, que consequentemente, se reverterão na redução dos poluentes na superfície deste planeta, reduzindo também a emissão dos gases do efeito estufa e na reversão dos efeitos catastróficos do aquecimento global ao longo do tempo. Na escola que devemos implantar esse novo paradigma (padrão) para lecionar aos nossos alunos, futuros cidadãos, que tragam e façam escolhas conscientes na busca da qualidade de vida (CORDULA, 2011).

\section{METODOLOGIA E COLETA DE DADOS}

Durante a construção da Ilha Interdisciplinar de Racionalidade, houve a participação dos alunos do pré II, totalizando 12 alunos do período matutino do CMEI Professora Julia Ribas Ferreira Araújo pertencente ao município de Palmas - PR. 0 trabalho realizado foi de caráter qualitativo, onde a coleta de dados se deu mediante registros de imagens e gravações de áudio, para análise qualitativa das respostas e comportamento dos alunos.

Quando concluída todas as etapas, foram retomadas as questões, referentes ao conteúdo exposto, para avaliar se a aprendizagem dos conteúdos foi realizada de forma significativa, e a proposta das atividades, carinha feliz e triste para o aluno pintar, avaliando assim se gostou ou não das atividades desenvolvidas. As perguntas feitas para os alunos tinham caráter interdisciplinar: 0 meio ambiente é importante? 0 que é meio ambiente? O que o papai e a mamãe fazem para cuidar do meio ambiente? Como devemos jogar o lixo de casa, tudo junto? Existe fórmula mágica para deixar o planeta limpinho? 0 que não serve para mim pode servir para outro?

Os dados foram analisados e estruturados para melhor demonstração dos resultados. As atividades foram desenvolvidas no espaço do CMEI interno e externo a instituição, todos os participantes das atividades tiveram a autorização dos responsáveis por meio de assinatura de um termo de consentimento elaborado pela professora regente da turma.

\subsection{ANÁLISE DE DADOS}

0 projeto em torno da IIR foi inicialmente desenvolvido para avaliação parcial de uma disciplina de mestrado, e posteriormente aplicado aos alunos do CMEI Professora Julia Ribas Ferreira Araújo. As atividades foram realizadas em 7 dias totalizando 35 horas aulas. 0 desenvolvimento da IIR se deu com base no vídeo "Turma da Mônica em um plano para salvar o planeta", para abordar os temas de sustentabilidade, fazendo relação com diversas disciplinas. Para realização das atividades foram seguidas as 8 etapas propostas por Fourez 2005:

Etapa 1: A situação clichê elaborada pelas professoras foi: Eu sou amigo do meio ambiente? Nesta fase foi apresentado um vídeo para os alunos da "Turma da Mônica em plano para salvar o planeta" e o vídeo "Animais Salvando o Planeta". Após os vídeos ocorreu uma conversa informal sobre meio ambiente, tipos de animais, poluição ambiental, coleta de lixo, reciclagem, desperdício de água e energia. Surgiram alguns questionamentos dos alunos. Aluno 2 "Meu pai e minha mãe não jogam o lixo separados"; Aluno 5 "Tem muito lixo na rua e não na lixeira". 


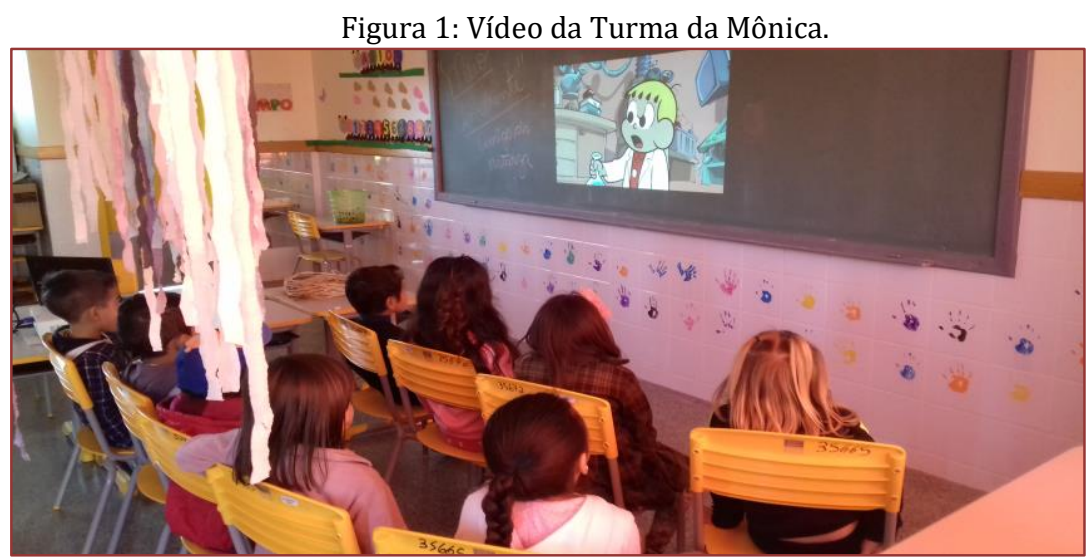

Elaborado pelo autor (2018).

Depois do vídeo foi elaborada outra situação clichê (2): Perguntas a respeito do meio ambiente. 0 que é meio ambiente? Por que o meio ambiente é importante? O que o papai e a mamãe fazem para cuidar do meio ambiente? 0 que devemos fazer com o lixo? Existe formula mágica para salvar o planeta? Alguma roupa que eu não uso mais, pode servir para outro? o que eu posso fazer para ser amigo do meio ambiente? Entre outras hipóteses que podem surgir por conta dos alunos. Então ocorreu um debate onde as crianças refletiram sobre as atitudes do cotidiano não só delas, mas também dos adultos com os quais elas convivem. Aluno 4: Faz uma reflexão que é preciso manter o planeta limpinho; Aluno2: Que não pode jogar o lixo no chão; Aluno 5: Que precisa cuidar da casa dos animais; Aluno 1: Que vai falar para a mãe jogar o lixo no lixo, porque não tem formula mágica para salvar o planeta.

Etapa 2: Panorama espontâneo. Foram selecionadas as dúvidas e curiosidades mais recorrentes apresentadas na situação clichê (2), e a partir disso, foram elencados os possíveis especialistas que poderiam auxiliar na resolução das questões e disciplinas com possíveis relações, foram designados para contribuir professores de Pedagogia, Letras, Ciências, Farmacêutico e Cozinheira do CMEI.

Etapa 3: Consulta aos especialistas. As etapas foram realizadas dentro do espaço escolar, em torno da escola, na comunidade e os alunos buscaram os professores das disciplinas citadas, elencaram suas principais dúvidas e realizaram entrevistas por meio de um jornal escolar. Juntos levantaram possíveis problemas ambientais vividos pela comunidade (lixos jogados pelas ruas, desperdício de água, energia, queimadas, etc.) e pensaram junto com as crianças em formas de resolver os problemas.

Etapa 4- Indo a prática: Aprofundamento do conhecimento dos alunos por meio de diversas atividades elaboradas por eles:

- Cartaz sobre meio ambiente; Passeio ao redor da escola com coleta de lixo; Mural ecológico; Confecção da lixeira para papel e orgânica de acordo com a cor da destinação correta do lixo; - Dinâmica separação de lixos (foram apresentados vários materiais, papel, latas, plásticos, para separação e destinação correta em cada lixeira de acordo com sua cor, amarela - metal, azul - papel, vermelho-plástico, verde - vidro, marrom - material orgânico); Quantidade; Animais em formato de números do 1 ao 9; Cores; Contação de história Galinha da angola; Vogais dos animais; Produção de livrinho; Teatro das cores das lixeiras; Palestra sobre poluição do ar; Experiência do talco; Pinturas; Jornal Pré II; Plantio de árvores no CMEI; Confecção de placas educativas; Contação de história os Animais que salvaram as árvores; Produção de cartaz com restos de pedaços de árvores; Palestra com o farmacêutico sobre doenças causadas pela poluição da água e do ar; Pintura sobre poluição; Destinação do resto de alimento que sobra na escola; Seminário apresentado para alunos convidados da Escola São Sebastião Palmas, com todas as atividades desenvolvidas; Reapresentação do vídeo da turma da Mônica para os alunos convidados, com direito a pipoca; Entrega de roupas, calçados e brinquedos arrecadadas pelos alunos; Desenvolvimento do bazar organizado pelos alunos; Questionamento final para avaliar se gostaram das atividades e para saber se foi significativo.

Etapa 5: abertura de caixas-pretas com a ajuda de especialistas. Nesta etapa, foram estudados os conceitos interdisciplinares acerca do tema trabalhado. As relações estabelecidas podem ser observadas na Figura 2: 
Figura 2: Esquema das relações interdisciplinares realizadas a partir do tema.

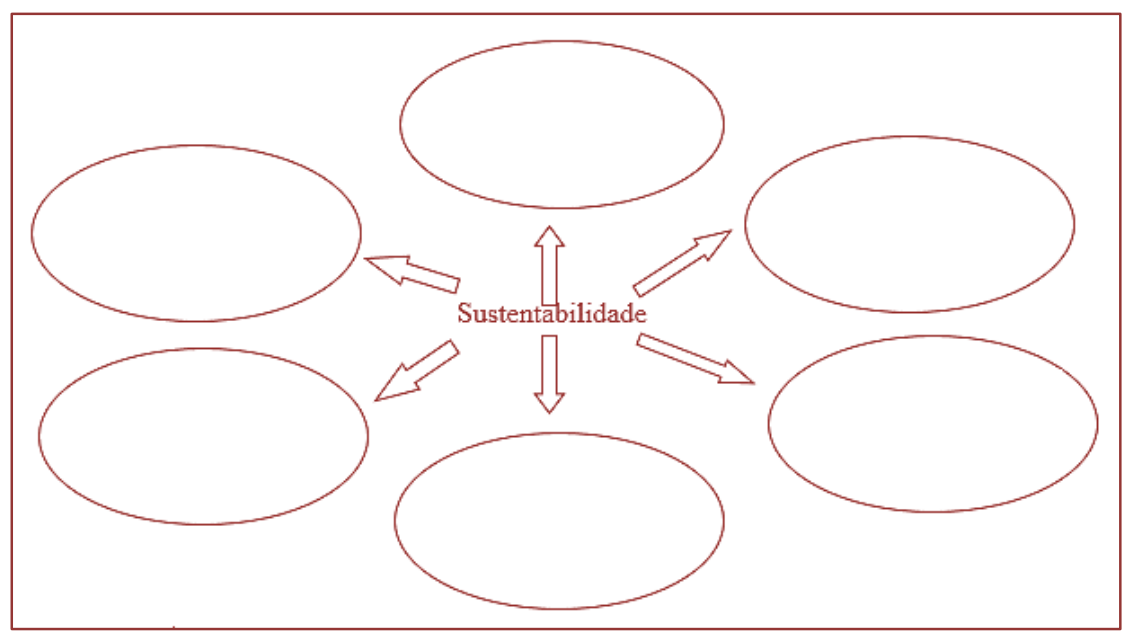

Etapa 6: Esquema global da situação estudada. Neste momento os alunos realizaram esquemas de todas as atividades que foram realizadas durante o desenvolvimento da IIR, com desenhos e pinturas.

Etapa 7: Abertura de caixas-pretas sem a ajuda de especialistas. Nesta etapa abre uma discussão entre os alunos para responder questões e sanar duvidas que ainda existam, nesta fase tivemos auxilio da internet para sanar questões que ainda não ficaram claras para as crianças.

Etapa 8: síntese da IIR produzida. A síntese final da IIR foi a condução realizada pelas crianças na arrecadação de roupas, promovendo um bazar que mobilizou a comunidade em torno do CMEI, as crianças decoraram o espaço onde ocorreu o bazar com todas as atividades desenvolvidas no projeto IIR, com o intuito de incentivar cada vez mais todos a preservarem o meio ambiente e incentivando a doação de roupas e outros itens com a mensagem final de que se não serve para mim, pode servir para o outro.

Com a finalização de todas as etapas e a certeza de que a construção e promoção do conhecimento foram desenvolvidas de forma autônoma pelas crianças, optou-se em avaliar o conhecimento adquirido por meio de um desenho com carinha triste e carinha feliz, para que os mesmos pintassem de acordo com a sua opinião sobre ter gostado ou não do projeto, o resultado obtido foi de que entre as 12 crianças, 08 pintaram a carinha feliz, 01 a carinha triste e 02 crianças não compareceram no dia desta atividade. Quando retomada as questões das situações clichê, foram obtidas as seguintes respostas: Aluno1: "É preciso manter o planeta limpinho, com o lixo no lixo, cuidando da casa dos animais".

Aluno 4: "Que precisa tomar banho rápido, para não acabar a água”.

Aluno5: "Separar o lixo, e doar o que eu não uso".

Aluno 6: “Cuidar das árvores, assim como as que nós plantamos, por causa do ar.

Apesar de pequenos, as crianças foram gigantes ao elaborarem essas respostas, demonstrando certo conhecimento adquirido na IIR, preocupando-se com o meio ambiente como um todo.

Tal atividade permite que os alunos tenham condições de tomar decisões, com responsabilidade e uma maior autonomia.

\section{CONSIDERAÇÕES FINAIS}

Utilizando a metodologia de IIR, o professor possui uma excelente ferramenta para avaliar a promoção da Alfabetização Científica, o interesse e também o comprometimento dos alunos, possibilita uma autonomia e promove um ser com consciência crítica, apto a tomar decisões, pois dominam o conteúdo e isso também lhes garante uma responsabilidade. A relação interdisciplinar só vem a somar, pois possibilita ao educando compreender os vários nichos das questões estudadas.

Durante o desenvolvimento da metodologia de IIR, foi possível observar o interesse e comprometimento por parte dos alunos, que foram autônomos na sua alfabetização científica em busca de novas informações acerca do tema proposto inicialmente na disciplina. Outro ponto a ser destacado são as relações, 
contribuindo de forma significativa também para que relacionassem com situações do seu cotidiano promovendo assim um maior entendimento da realidade. 0 trabalho foi significativo, visto ter envolvido não somente a comunidade escolar, mas a comunidade em torno da escola, com o objetivo de despertar a reflexão sobre a questão: Eu sou amigo do meio ambiente? Tomando algumas atitudes simples no seu diaa-dia se consegue ajudar a promover o cuidado com o ambiente, permitindo zelar dos recursos naturais do Planeta.

\section{REFERÊNCIAS}

[1] BETTANIN, E. As ilhas de racionalidade na promoção dos objetivos da alfabetização científica e técnica. Dissertação (Mestrado em Educação). UFSC. Florianópolis, 2003. 160 p.

[2] CóRDULA, E. B. L. O ser humano: da concepção criacionista à holostêmica. Rev. Educação Pública, n 31, 31 mar. 2011. Disponível em: http://www.educacaopublica.rj.gov.br/biblioteca/filosofia/0069.html. Acesso em: 28 jul. 2017.

[3] GRÜN, Mauro. Ética e educação ambiental: a conexão necessária. 11 ed. Campinas, SP: Papirus, 2007.

[4] FOUREZ, G. Alfabetización científica y tecnológica. Acerca de las finalidades de la enseñanza de las ciencias. Buenos Aires, Argentina: Ediciones Colihue, 1997.

[5] FOUREZ, G. Crise no Ensino de Ciências? Revista Investigações em Ensino de Ciências. Porto Alegre, v. 8, n. 2, p.109 -123, ago. 2003.

[6] FOUREZ, G. Alfabetización científica y tecnológica: acerca de las finalidades de la enseñanza de las ciencias. Buenos Aires: Colihue, 2005.

[7] HODSON, D. (1992). In search of a meaningful relationship: an exploration of some issues relating to integration in science and science education. International Journal of Science Education, 14, 541-562.

[8] PIETROCOLA, M. O. Construção e realidade: o realismo científico de Mário Bunge e o ensino de ciências através de modelos. Investigações Científicas, Instituto de Física, Universidade Federal do Rio Grande do Sul, Porto Alegre, Brasil, v.4, n.3, dezembro de 1999.

[9] UNESCO, 2005; Década da Educação das Nações Unidas para um Desenvolvimento Sustentável, 2005-2014: documento final do esquema internacional de implementação. Brasília 


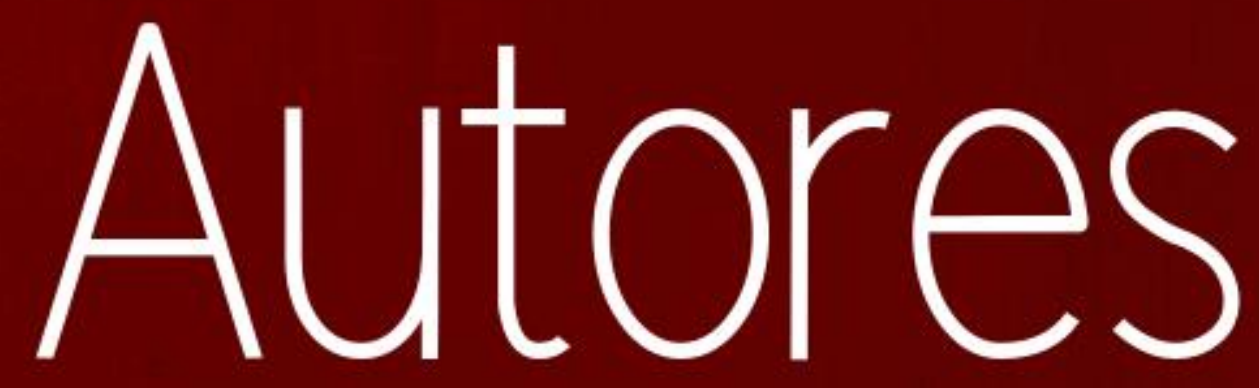




\section{MARIA CÉLIA DA SILVA GONÇALVES (ORGANIZADORA)}

Pós-doutorado em Educação pela Universidade Católica de Brasília (UCB). Estágio Pós-doutoral em Economic History Department of Law, Economics, Management and Quantitative Methods-DEMM da Università degli Studi Del Sannio - UNISANNIO-(Benevento, Italy). Visiting Professor da Università degli Studi Del Sannio - UNISANNIO. Pós-doutoranda em História pela Universidade de Évora em Portugal. Possui doutorado em Sociologia pela Universidade de Brasília (2010),mestrado em História pela Universidade de Brasília (2003), especialização em História pela Universidade Federal de Minas -UFMG (1998). Graduação em Geografia(2012) pela Faculdade Cidade de João Pinheiro (FCJP) Complementação em Supervisão Escolar(1993) pelas Faculdades Integradas de São Gonçalo, graduação em em História (1991) e em Estudos Sociais (1989) pela Faculdade do Noroeste de Minas. Atua como professora de História do Direito, Sociologia e Metodologia Científica Faculdade do Noroeste de Minas (FINOM). Coordenadora do Núcleo de Pesquisa e Iniciação Científica e Professora de Trabalho de Conclusão de Curso (TCC) nos cursos de Pedagogia, Administração da Faculdade Cidade de João Pinheiro (FCJP). Avaliadora do Sistema Nacional de Avaliação da Educação Superior do Ministério da Educação - MEC/INEP. Presidente do Conselho Municipal do Patrimônio Cultural de João Pinheiro(MG). Atualmente é pesquisadora do Comunidade Escolar: Encontros e Diálogos Educativos - CEEDE, do Programa de Pós- Graduação em Educação da UCB .Membro da KINETÈS - Arte. Cultura. Ricerca. Impresa (UNISANNIO). Investigadora visitante no CIDEHUS Centro Interdisciplinar de História, Culturas e Sociedades da Universidade de Évora em Portugal. Ocupante da cadeira de número 35 na Academia de Letras do Noroeste de Minas. Tem experiência na área de História e Sociologia, atuando principalmente nos seguintes temas: artes-folia- festascultura popular-performance- identidade e memória.

\section{BRUNA GUZMAN DE JESUS (ORGANIZADORA)}

Graduada em Pedagogia: docência e gestão pela PUC Minas (2009), pós-graduada em Orientação, Supervisão e Gestão Escolar (2020) assim como em Metodologia do Ensino de Língua Portuguesa e Língua Estrangeira (2014) pelo Grupo Educacional UNINTER/ FACINTER - Faculdade Internacional de Curitiba. Pós-graduanda em Neuropsicopedagogia pela Faculdade Metropolitana - MG. É Coordenadora Pedagógica.

\section{ANA BEATRIZ DOS SANTOS ARAÚJO}

Estudante do $2^{\circ}$ ano do ensino médio integrado ao curso técnico em agropecuária do Instituto Federal de Educação, Ciência e Tecnologia - Campus Belo Jardim, em Pernambuco.

\section{ANA CAROLINA MARTINS WILLE}

Licenciada em Ciências Biológicas pela Universidade Estadual de Ponta Grossa (2001), mestre em Biologia Celular e Molecular pela Universidade Federal do Paraná (2006), doutora em Biologia Celular e Molecular na Universidade Federal do Paraná (2014). Atualmente é professora Adjunta da Universidade Estadual de Ponta Grossa. Tem experiência na área de Bioquímica e Morfologia (Biologia Celular e Histologia), atuando principalmente nos seguintes temas: Toxinas de venenos de animais peçonhentos (nativas e recombinantes), loxoscelismo e proliferação celular.

\section{ANA CRISTINA XAVIER LEANDRO DE OLIVEIRA}

Possui Graduação em Serviço Social (2010) pela Faculdade de Excelência Educacional - FATERN; Pós-Graduada em Gestão Pública Ambiental e Desenvolvimento Regional pela FATERN (2012). Pósgraduada em Psicopedagogia Clínica e Institucional na Faculdade Estácio de Sá. Idealizadora (2016). Idealizadora do Projeto "Berçário: Plantando a semente" que trabalha com a metodologia da Educação Ambiental que visa o incentivo para uma inclusão da Educação Ambiental no contexto doutrinário evangélico como proposta renovadora de ensino à categoria infanto-juvenil. 


\section{ANA KATARINA NASCIMENTO DE AZEVEDO}

Mestre em Biologia pela UFMG vinculada a UFPB. Aluna do curso de Pedagogia - Instituto Kennedy (2020). Possui graduação em Direito pela Faculdade de Natal (2012), graduação em Ecologia pela Universidade Federal do Rio Grande do Norte (2015) e graduação em ciências Biológicas pela Universidade Federal do Rio Grande do Norte (2002). Atualmente é professora permanente biologia - Secretaria estadual do Rio Grande do Norte, professora permanente - ciências - Secretaria Municipal de educação de Natal. Tem experiência na área de Biologia Geral, com ênfase em Biologia Geral, atuando principalmente nos seguintes temas: ensino fundamental II, Ensino médio, educação ambiental e educação com o uso de HQ.

\section{ANA PAULA MAGAGNIN PRZYVARA}

Possui Curso Técnico Profissionalizante (magistério) pelo Colégio Estadual Dom Carlos, Graduação em Ciências Biológicas pelo Instituto Federal do Paraná (IFPR-Campus Palmas), Pós-graduação em Educação Ambiental e Sustentabilidade na UNINTER. Pós-graduação em Metodologia da Química e Biologia na UNINTER, Pós- graduação Ensino Profissionalizante na Faculdade São Braz . Mestrado em Ensino de Ciência e Tecnologia pela UTFPR . Possui experiência na área ambiental com ênfase em conservação da biodiversidade e na área docente.

\section{ANAIARA LOURENÇO DA SILVA}

Bacharel em Direito; Pedagoga; Psicopedagoga Institucional; Gestora Educacional: Administração, Orientação, Supervisão, Coordenação e Inspeção Escolar; Neuropsicopedagoga; Educadora Especial com ênfase nas Deficiências Físicas, Intelectuais e Psicomotoras; Mestranda em Educação - Práticas Educativas, Formação de Professores e Inclusão.

\section{AWDRY FEISSER MIQUELIN}

Graduação em Licenciatura em Física pela Universidade Estadual de Ponta Grossa (2000), mestrado em Educação pela Universidade Federal de Santa Maria (2003) e Doutorado em Educação Científica e Tecnológica pela Universidade Federal de Santa Catarina (2009). Atualmente sou professor Associado II no Departamento Acadêmico de Ensino da Universidade Tecnológica Federal do Paraná - Campus Ponta Grossa, professor do Programa de Pós-Graduação em Ensino de Ciência e Tecnologia (Câmpus Ponta Grossa) Mestrado e Doutorado.

\section{BARBÁRA DE OLIVEIRA GONÇALVES}

Mestra em Educação pelo Programa de Pós Graduação em Educação da Universidade do Estado do Rio de Janeiro (2018). Graduada em Pedagogia pela Universidade do Estado do Rio de Janeiro (2014). Membro do Grupo de Pesquisa "Infância e Saber Docente" do PROPEd/UERJ. Professora de Educação Infantil da rede municipal do Rio de Janeiro. Atua principalmente nos seguintes temas: educação, educação infantil, participação infantil, sociologia da infância, movimentos sociais e populares.

\section{BRUNO ABEL RESENDE SILVA}

Possui ensino médio segundo grau pelo Colégio Dom Alberto Gonçalves (2017). Atualmente é graduando de Bacharelado em Enfermagem pela Universidade Estadual de Ponta Grossa, orientado da Iniciação Científica "Estudo dos efeitos de Fosfolipases-D de aranhas do gênero Loxosceles em culturas de queratinócitos". Dispõe de interesse no tema Acidentes por Animais Peçonhentos com interface ao Loxoscelismo. Paralelamente também participa de estudos acerca da prevenção de IST's e gravidez via projeto de extensão "Papo reto: conversando sobre prevenção a gravidez e a IST's, nas Unidades de Saúde da cidade de Ponta Grossa, Paraná". 


\section{CAMILA APARECIDA SILVA ROSA MARINELO}

Possui graduação em Normal Superior (2005) e graduação em Pedagogia (2006) pela Universidade do Vale do Paraíba, especialização lato sensu em Psicopedagogia Clínica e Institucional pelo Instituto Superior de Educação da América Latina (2010), especialização lato sensu em Gestão Escolar e Coordenação Pedagógica pela Universidade de Taubaté (2014) e Mestrado em Desenvolvimento Humano pela Universidade de Taubaté. É Professora de Educação Básica I (efetiva), exercendo a função de Orientadora Educacional, junto a Prefeitura Municipal de São José dos Campos, interior de São Paulo. Opera principalmente nos seguintes temas: educação, interdisciplinaridade, legislação educacional, gestão democrática escolar, justiça restaurativa escolar e comunicação não-violenta.

\section{CARLOS EDUARDO GOMES DE BARROS}

Possui graduação em Licenciatura em Ciências Biológicas pela Universidade Federal de Pernambuco- UFPE (2015) e graduação em Pedagogia pelo Centro Universitário FACOL- UNIFACOL (2018). Especialista em Ensino de Ciências Biológicas pelo Centro Universitário da Vitória de Santo Antão- UNIVISA e em Neuropedagogia e Educação Inclusiva pela mesma instituição. Atualmente é servidor público da Rede Estadual de Pernambuco exercendo a função de professor das disciplinas de biologia e química na EREM Senador João Cleofas de Oliveira, vinculada a Gerência Regional de Educação Mata Centro.

\section{CAROLINE AMANDA DA SILVA}

Possui ensino médio segundo grau pelo Colégio Sagrada Família (2017). Atualmente é graduanda de enfermagem da Universidade Estadual de Ponta Grossa. Atuando principalmente nos seguintes temas: loxoscelismo e tabagismo.

\section{CLÁUDIA BOTELHO SILVA}

Licenciada em Letras: Português- Inglês pela Universidade Federal Fluminense, tendo realizado curso de Especialização em Linguística Aplicada ao ensino do inglês como língua estrangeira pela mesma universidade. Mestre em Educação pela Universidade Estácio de Sá (UNESA). Atua como professora de inglês nas redes pública e privada desde 1989. É professora de inglês da Fundação de Apoio à Escola Técnica (FAETEC) desde 2000, atualmente está lotada na Escola Estadual de Ensino Fundamental Henrique Lage, e leciona língua inglesa e língua portuguesa para alunos do Ensino Fundamental II. Dedica-se a pesquisas na área dos Estudos do Cotidiano, Ensino da Língua Inglesa e Formação Docente.

\section{CLÁUDIA VIANNA DE MELO}

Professora da Carreira do Magistério da Educação Básica Técnica e Tecnológica da Universidade Federal Fluminense (UFF) possui Graduação em Pedagogia pela UFF, Especialização em Educação Infantil pela Pontifícia Universidade Católica do Rio de Janeiro, Mestrado e Doutorado em Educação pelo Programa de Pós-Graduação em Educação da Universidade do Estado do Rio de Janeiro (CAPES 7). Integrante do Grupo de Pesquisa Infância e Saber Docente sob a coordenação da professora doutora Ligia Maria Leão de Aquino. Especialização em Música na Educação Infantil pelo Conservatório Brasileiro de Música, em andamento.

\section{CLEYTON DA SILVA MACIEL}

Discente do Instituto Federal de Educação, Ciência e Tecnologia - PE. Cursando ensino médio integrado ao curso Técnico de Informática para Internet. Engajado na atuação social com o foco na melhor a da vida de suas conterrâneos por meios econômicos e ambientais sustentáveis. Busca o desenvolvimento próprio e do seu derredor. 


\section{CREUZELI APARECIDA SOARES DE LIMA}

Estudante no 4ํa ano de Pedagogia pelo Centro Universitário Leonardo da Vinci (UNIASSELVI), 2020.

Estagiária pela Rede Municipal de Maringá (2018-2020)

\section{CRISTINA LÚCIA SANT'ANA COSTA AYUB}

Bacharel em Biologia pela UFV (1988)Mestre em Zootecnia pela UFV (1991)Doutora em Biologia Celular e Molecular pela UFPR (2006)Docente Associado, Departamento de Biologia Estrutural, Molecular e Genética, Setor de Ciências Biológicas e da Saúde, Universidade Estadual de Ponta Grossa, desde 1996.

\section{DANIELI MARTINS AMBRÓS}

Autora Danieli Martins Ambrós, graduada em 2015 em Educação Especial- Diurno pela Universidade Federal de Santa Maria. Em 2018, realizou a Especialização em Psicopedagogia- Clínica e Institucional pela Universidade Franciscana. E no começo de 2021 irá se formar em Pedagogiapresencial na Universidade Franciscana.

\section{DANILO RAMOS CAVALCANTI}

Possui graduação em Licenciatura em Ciências Biológicas (2010), Mestrado em Biotecnologia Industrial (2013) e Doutorado em Ciências Biológicas (2018) pela Universidade Federal de Pernambuco. Atualmente é professor, pesquisador e membro do comitê de ética em pesquisa com seres humanos do Centro Universitário da Vitória de Santo Antão (UNIVISA). Tem experiência na áreas de Metodologias Ativas no Ensino Superior e Microbiologia associada à Bioquímica e à Biologia Molecular com ênfase em Proteômica e Processos Fermentativos; Parasitologia Clínica, com ênfase em Biologia Celular.

\section{DANISLEI BERTONI}

Professor dos cursos de Licenciatura Interdisciplinar em Ciências Naturais e Licenciatura em Ciências Biológicas, UTFPR Campus Ponta Grossa. (2) Professor do Mestrado em Ensino de Ciência e Tecnologia, PPGECT, UTFPR Campus Ponta Grossa. FORMAÇÃO: (1) Licenciatura em Biologia, Faculdades Integradas Espírita; (2) Pós-Graduação Latu Sensu em Espaço, Sociedade e Meio Ambiente, com habilitação em Magistério Superior, Faculdades Integradas Espírita/IBPEX; (3) Mestrado e Doutorado em Educação, UFPR.

\section{EDILEUZA FERNANDES SILVA}

Professora aposentada da SEEDF. Foi subsecretária de educação básica do DF, ex presidente da Câmara de educação básica do Conselho de Educação do DF. Coordenou a elaboração do Currículo em Movimento da educação básica. Professora da Faculdade de Educação da UnB, líder do Grupo de Estudos e Pesquisa em Docência, Didática e Trabalho Pedagógico - PRODOCÊNCIA da FE/UnB. Coordena o Observatório de Educação Básica da FE/UnB.

\section{EMANUELLA BARROS DE SOUZA OLIVEIRA ALVARES}

Graduada em Licenciatura Plena em Ciências Naturais - Habilitação em Biologia pela FAINTVISA (2007). Tem Especialização em Gestão Ambiental - FAINTVISA (2009). Atualmente é Coordenadora do Curso de Licenciatura Plena em Biologia no Centro Universitário da Vitória de Santo Antão. 


\section{ERIVELTON SANTOS RODRIGUES}

Pós-Graduando no Mestrado Profissional em Ciência, Educação e Tecnologia pela Faculdade Vale do Cricaré (FVC). Especialista em Educação, Cultura e Memória (UESB). Graduado em Licenciatura em Geografia pela Universidade Estadual do Sudoeste da Bahia (UESB).

\section{EUNICE MARIA DA SILVA}

Mestrado em Educação Brasileira pela Universidade Federal de Alagoas - UFAL (2010). Especialização em Orientação Educacional pela Universidade Salgado de Oliveira - RJ (1996). Graduação em Pedagogia pela Universidade do Estado da Bahia - UNEB. Professora efetiva do Departamento de Educação da Universidade do Estado da Bahia, ministrando os componentes curriculares de Educação de Jovens e Adultos, Pesquisa e Prática Pedagógica e Avaliação em Educação. Coordena o projeto de pesquisa e extensão "GEMPEED". Tem experiência em Gestão Acadêmica e de Projetos Sócio-Educacionais; Planejamento e Avaliação Educacional; Intervenções Psicopedagógicas; Formação de Docentes da Educação Básica e do Ensino Superior.

\section{EVA BEGO}

Atua como Auxiliar Educacional pela Rede Municipal de Maringá-Pr. Estudante no $4^{\circ}$ ano de Pedagogia pelo Centro Universitário Leonardo da Vinci (UNIASSELVI), 2020.

\section{FLAVIANA AMÉRICA SILVA DANTAS DE SOUZA}

Graduada em Letras e pós-graduada em Linguística aplicada ao ensino de Língua Portuguesa pela Universidade de Pernambuco (UPE); Mestre em Letras pela Universidade de Pernambuco (UPE); Professora de Língua Portuguesa há quatorze anos dedicados ao ensino público e também privado.

\section{GIOVANNA VELLOSO DOS SANTOS}

Mestre em Desenvolvimento Humano pela Universidade de Taubaté; Graduada em Letras - Língua Portuguesa, Língua Inglesa e Respectivas Literaturas pela Universidade de Taubaté (2007); Graduada em Pedagogia pela Faculdade Paulista São José (2014) e Pós-graduada em Docência para o Ensino Superior pela Faculdade INESP (2018). Tem experiência na área de Educação com ênfase em Administração Educacional. Atuou como professora de Educação Infantil, professora de Língua Portuguesa para o Ensino Fundamental II, professora de Língua Portuguesa em curso preparatório para concurso público, coordenadora pedagógica do Ensino Fundamental e gestora escolar. Atualmente é Supervisora de Ensino na Prefeitura Municipal de Taubaté e Professora no curso de Pedagogia no Centro Universitário UNIPLAN.

\section{GRAZIELA ESCANDIEL DE LIMA}

Formação: Pedagogia/UFSM, Mestrado em Educação/UFSM, Doutorado em Educação/PUC-RS. Professora da Universidade Federal de Santa Maria/RS. Professora do Departamento de Metodologia do Ensino/Centro de Educação/Universidade Federal de Santa Maria/RS. Têm experiência na área de Educação, Formação de Professores em cursos de Pedagogia e Estágios. Professora no Programa de Pós Graduação em Políticas Públicas e Gestão Educacional - Mestrado Profissional. Coordenadora do Grupo de Pesquisa TRAVESSIAS. Seus estudos têm ênfase na Educação Infantil, Infâncias, Cotidiano, Docência e Trabalho Pedagógico.

\section{GUILHERME FERREIRA DOS SANTOS}

Universitário cursando Bacharelado em Enfermagem na Universidade Estadual de Ponta Grossa. Previsão de conclusão do curso de Graduação: 2021. 


\section{IGOR AFFONSO DE PAIVA}

Licenciado em Ciências Biológicas (2007) com Mestrado (2012) e Doutorado (2015) em Ciências Ambientais na Universidade Estadual de Maringá. Trabalhei em uma reserva marinha na Nova Zelândia (Piopiotahi Marine Reserve) de 2008 a 2009, onde atuei como educador ambiental e mergulhador. Trabalhei também como pesquisador convidado na Universidade de Girona (Espanha, 2013) e na Universidade de Lund (Suécia, 2014). Ministrei aulas de diversas disciplinas relacionadas a Ecologia, Conservação, Zoologia, Estatística e Redação Científica para graduação e pós-graduação (Latu e Stricto Sensu). Atualmente sou professor Adjunto da Universidade Tecnológica Federal do Paraná - Campus Ponta Grossa, onde oriento no Programa de Pós-graduação em Ensino de Ciência e Tecnologia

\section{INÊS BARBOSA DE OLIVEIRA}

Doutora em Sciences Et Théories de L'éducation - Université de Sciences Humaines de Strasbourg (1993). Pós-doutora pelo Centro de Ciências Sociais da Universidade de Coimbra (2002) e titulada HDR (Habilitação para dirigir pesquisas) pela Université de Rouen (França, 2013). Professora titular da Universidade do Estado do Rio de Janeiro (UERJ) e professora adjunta do Programa de pósgraduação em Educação da Universidade Estácio de Sá.Pesquisadora associada ao GT Políticas Educacionais do CLACSO. Bolsista PQ 1C do CNPq e Cientista do Nosso Estado FAPERJ. Atua e possui publicações voltadas aos debates em torno da emancipação social democratizante, com foco nos seguintes temas: novas epistemologias em educação, pesquisa nos/dos/com os cotidianos, currículos praticadospensados e cotidiano escolar; direito à educação e políticas educacionais.

\section{ISABEL MARTH DE SOUZA}

Possui Curso Norma/Magistério, Graduação em Pedagogia pela ULBRA/Canoas, Cursando Pós em Educação pelo IFSUL Campus Sapucaia. Atuou na rede privada de ensino do Município de Cachoeirinha no período de 2008 a 2015, em 2015 ingressou na rede Pública de Ensino de Cachoeirinha através de ingresso por Concurso Público, onde trabalha até o presente momento. Atualmente atua na EMEI Beija-flor do Bosque, com turmas de maternal e pré-escola.

\section{JACKSON JOSÉ PAGANI}

Possui graduação em Filosofia pela Universidade Estadual de Maringá e Pedagogia pela Faculdade de Paraíso do Norte - FAPAN. Atualmente é Orientador Pedagógico do Colégio SESI-Maringá e Tutor Externo da Sociedade Educacional Leonardo da Vinci - UNIASSELVI. Com especialização em Psicopedagogia Institucional, Educação de Jovens e Adultos - EJA, Educação Especial, Mestre em Estudos Literários pela Universidade Estadual de Maringá e Doutorando pela mesma Universidade.

\section{JULIANA DE SOUZA COSTA}

Graduanda em Pedagogia na Universidade de Brasília (UnB). Pesquisou as influências da relação pedagógica no processo de ensino-aprendizagem no $5^{\circ}$ ano do ensino fundamental através do Programa de Iniciação Científica (ProIc) em 2019/2020 sob orientação da Professora Doutora Edileuza Fernandes Silva. Participa do Grupo de Estudos e Pesquisa em Docência, Didática e Trabalho Pedagógico - PRODOCÊNCIA da FE/UnB cadastrado no Cnpq.

\section{JULIANE MARSCHALL MORGENSTERN}

Graduada em Educação Especial e Pedagogia. Especialista em Gestão Educacional. Mestre e Doutora em Educação. Professora da Universidade Franciscana (UFN). Coordenadora do Curso de Pedagogia Ead (UFN). Colaboradora do Curso de Mestrado em Ensino de Humanidades e Linguagens (MEHL/UFN). 


\section{LAURACI DONDÉ DA SILVA}

Possui Curso Normal/Magistério, graduação em Pedagogia Magistério e Orientação Educacional pela Universidade de Caxias do Sul (1978), Pós-Graduação em Administração e Supervisão de Organizações Educacionais pela UNISINOS (1982), doutorado em Ciências da Educação pela Universidade Pontifícia de Salamanca (1998), validado pela USP em 2001, MBA em Gestão de Unidades Educacionais pela ULBRA com 390h (2005) e curso de Bioética Aplicada às Pesquisas Envolvendo Seres Humanos, pela Coordenação de Educação a Distância da Escola Nacional de Saúde Pública Sergio Arouca - EAD/ENSP, da Fundação Oswaldo Cruz-FIOCRUZ (2010). Membro do Comitê de Ética nas Pesquisas com Seres Humanos - CEP da ULBRA (até 10/01/19) Professora titular e pesquisadora da Universidade Luterana do Brasil (até 10/01/19). De 11.02.2019 até hoje atua como coordenadora de Ensino no Colégio Maria Auxiliadora de Canoas.

\section{LETICIA SOUSA DOS REIS}

Graduanda em Licenciatura Plena em Educação Física pela UEPB.

\section{MÁRCIA MARIA DIAS REIS PACHECO.}

Possui graduação em Pedagogia pela Universidade de Taubaté (1992), Mestrado em Educação: Psicologia da Educação pela Pontifícia Universidade Católica de São Paulo (2002) e Doutorado em Educação: Psicologia da Educação pela Pontifícia Universidade Católica de São Paulo (2008). Atualmente é Professor Assistente Doutor da Universidade de Taubaté efetivo (2010), lotado no Departamento de Pedagogia, concursada na disciplina de Didática com atuação na graduação e pósgraduação.Tem experiência na área de Educação, com ênfase em Didática, Didática do Ensino Superior e Psicologia da Educação. Atua como Supervisor de Ensino pela Secretaria de Educação do Estado de São Paulo. Compõe o corpo permanente de docentes do curso de Mestrado Interdisciplinar de Desenvolvimento Humano: formação, políticas e práticas sociais. Suas Áreas de Pesquisa são: Formação de Professores, Avaliação Educacional e Políticas Públicas.

\section{MARCOS DE FIGUEIREDO ANDRADE}

Graduado em Ciências Biológicas (Licenciatura) pela Universidade Federal De Pernambuco, Centro Acadêmico de Vitória - CAV - UFPE. Especialista no Ensino de Ciências Biológicas pela FAINTVISA Faculdades Integradas da Vitória de Santo Antão. Atuou como Estagiário do Laboratório de Biotecnologia e Fármacos - UFPE - CAV e no desenvolvimento de atividades referentes a projetos de pesquisa e extensão da UFPE - CAV. Atua como Professor da Educação Básica (Ensino Fundamental Anos Finais) na Secretaria Municipal de Educação de Orobó - PE.

\section{MARIA DE FÁTIMA CAMAROTTI}

Doutora em Ciências Biológicas, UFPB, 2004; Bacharela e Licenciada em Ciências Biológicas, UFRPE/UFPB, 1987/2005 e Pós-doutorado em Ensino de Ciências pelo PPGEC/UFRPE em 2018. Professora Associada do DME/CE/UFPB; Coordenadora do Mestrado Profissional em Ensino de Biologia em Rede Nacional - PROFBIO/UFPB; participa dos grupos de Pesquisa do CNPq em Educação Ambiental, Ensino de Ciências/Biologia e Malacologia - GPBioMA, Formação e \prática Pedagógica de Professores de Ciências e Biologia - FORBIO/UFRPE e Pesquisas e Estudos Interdisciplinares em Ensino de Ciências Biológicas - PROFBIO/UFPB.

\section{MARIA MADALENA DE MELO FELICIANO}

Graduada em Pedagogia pelo o Instituto Superior de Educação São Judas Tadeu, especialista em Psicopedagogia clínica e institucional. Pós graduanda em Coordenação Pedagógica e Supervisão escolar. Professora do ensino fundamental I durante 2 anos. Professora voluntária das turmas do $1^{\circ}$ e $2^{\circ}$ ano do ensino fundamental I durante 8 meses. 


\section{MARIANA LUIZA CLAUDINO MATARUNA}

Possui ensino médio completo pelo Colégio Positivo Master do Grupo Positivo (2017). Atualmente é graduanda de Bacharelado em Enfermagem pela Universidade de Ponta Grossa (UEPG), orientada da Iniciação Científica "Avaliação histológica da pele de coelhos submetidos ao tratamento com toxinas (ativas ou neutralizadas) do veneno de aranha do gênero Loxoceles" e atuando no Projeto de Extensão "Educando e Tratando o Tabagismo UEPG".

\section{MARILEI ALMEIDA DE OLIVEIRA}

Pedagoga/UFSM; Especialista em Gestão Educacional/UFSM; Mestranda em Políticas Públicas e Gestão Educacional/UFSM; Professora de Educação Infantil e Anos Iniciais da rede municipal de Santa Maria. Integra o Grupo DIALOGUS - Educação, Formação e Humanização com Paulo Freire registrado na Base do CNPq. Contadora de Histórias. Pesquisa e realiza estudos sobre Pedagogia, Formação de Professores, Gestão Educacional, Classe Hospitalar e Educação Infantil.

\section{MARITIELE DE ARAÚJO BORGES}

Graduando na Pedagogia- Universidade Franciscana, com intenção de forma-se no final de 2021. No momento atua na área de educação como auxiliar de turma em escola particular de Santa Maria- RS.

\section{MIRTES RIBEIRO DE LIRA}

Professora adjunta da Universidade de Pernambuco, do Programa de Pós-Graduação em Educação - Formação de Professores e Práticas Interdisciplinares - Mestrado Profissional - da Universidade de Pernambuco campus Petrolina. Pós-doutora em Educação pela Universidade Federal de Pernambuco. Líder do grupo de pesquisa Linguagem, cognição e subjetividade e membro do Grupo de Pesquisa Educação em Ciências Naturais da UFPE. Atuando principalmente, nos seguintes temas: práticas discursivas e pedagógicas, currículo e formação docente e ensino de ciências.

\section{PAMELA RENATA OLIVEIRA PONTAROLO}

Possui ensino médio segundo grau pelo Colégio Estadual Professor João Ricardo Von Borell Du Vernay (2014). Atualmente é graduanda de Enfermagem pela Universidade Estadual de Ponta Grossa (UEPG). Atuando principalmente com o tema Loxoscelismo. Atualmente realiza Iniciação Científica com a pesquisa de Avaliação do efeito de Fosfolipases-D recombinantes do veneno de aranhas marrom sobre as fibras reticulares da derme.

\section{PATRÍCIA MARIANA VASCO DE GÓZ}

Mestra em Ensino das Ciências pela Universidade Federal Rural de Pernambuco (UFRPE). Especialista em Ensino de Ciências Biológicas pela Faculdades Integradas da Vitória de Santo Antão (FAINTVISA) e Graduada em Licenciatura em Ciências Biológicas pela Universidade Federal de Pernambuco - Centro Acadêmico de Vitória (UFPE/CAV). Possui experiência em pesquisas no campo da Ecologia de Morcegos, Educação Ambiental e Ensino de Ciências.

\section{PRISCILLA CRISTINA GEORG}

Graduada em Zootecnia pela Universidade Estadual de Maringá-UEM (2004); Mestre em Zootecnia pela Universidade Estadual de Maringá- UEM (2007), na área de Genética e Melhoramento Animal. Especialista em Planejamento Ambiental pela UniCesumar (2008). Atualmente no $4^{\circ}$ ano de Pedagogia pelo Centro Universitário Leonardo da Vinci (UNIASSELVI), 2020. 


\section{RAFAEL OLIVEIRA DE ANTONIO}

Mestrando em Educação Escolar na Universidade Estadual Paulista - Unesp, Câmpus de Araraquara. Graduado em Educação Física pela Unesp, Câmpus de Bauru. Tem experiência na área de Educação, com ênfase em: cultura corporal, educação infantil, psicologia histórico-cultural e pedagogia histórico-crítica.

\section{ROGÉRIO FERREIRA DA SILVA}

Bacharel em Química pela UFPE, licenciado em Química pela UFRPE, mestre e doutor em Química pela UFPE. Professor doutor do Instituto Federal de Educação, Ciência e Tecnologia de Pernambuco.

\section{SILVIO SANCHES VEIGA}

Possui graduação em Farmácia e Bioquímica pela Universidade de São Paulo (1986) e doutorado em Bioquímica pela Universidade de São Paulo (1994), Livre-Docência pela UNICAMP em 2002. Atualmente é Prof. Titular do Departamento de Biologia Celular na Universidade Federal do Paraná, onde também foi Coordenador do Programa de Pós-Graduação em Biologia Celular e Molecular (Setembro de 2008 até Agosto de 2010). Foi membro do Comitê de Avaliação da Área de Morfologia 2013-2016. Tem experiência na área de Morfologia, com ênfase em Citologia e Biologia Celular, atuando principalmente nos seguintes temas: Biotecnologia e Biologia molecular de venenos, aranha marrom, toxinas, matriz extracelular e adesão celular.

\section{STELLA GRIMALDI GOMES POLITO}

Doutora e mestre em Educação Escolar pela UNESP-FCLAr. Psicopedagoga pela UNIARA. Pedagoga pela UNESP-FCLAr. Com experiência na área de Educação Básica, atuando principalmente nos seguintes temas: autonomia, planejamento participativo, prática reflexiva e educação escolar.

\section{TATIANE EVANGELISTA ZILS}

Formada em Licenciatura em Ciências Biológicas pela UEPG, Pedagogia pela UNINTER, Pós Graduação em Educação Ambiental, Educação Especial, Educação Básica Infância e Ludicidade. Mestra em Ensino de Ciência e Tecnologia pela UTFPR.

\section{VANDERLEA DOS SANTOS SILVA}

Graduada em pedagogia e pós graduanda em psicopedagogia clínica e institucional pela Faculdade do Sertão do Pajeú (FASP). Atua como professora na Creche Municipal da Ingazeira - PE.

\section{VANESSA ULIANA BENEDICTO}

Especialista em Psicomotricidade, Ludopedagogia e Neuropsicopedagogia pelos Campos Eliseos. Pedagoga pela Uniderp. Com experiência na área de Educação Infantil, com ênfase no Berçário $[0$ a 2 anos), atuando principalmente nos seguintes temas: creche, psicomotricidade, cotidiano escolar e prática reflexiva.

\section{VIVIANE MARQUES SOUSA E SILVA}

Graduada em licenciatura Química pela UEPB, Especialista em Fundamentos da Educação com ênfase em Práticas Pedagógicas Interdisciplinares. Atualmente é aluna do Mestrado em Ensino de Ciências e Educação Matemática da UEPB. Integrante do Projeto Internacional Universidades Inclusivas: SOLIDARES. Menbro do Grupo de Pesquisa em Metodologias para o Ensino de Química GPMEQ (UEPB). 


\section{WILVANIA CARVALHO DE SOUZA PAIVA}

Possui graduação em Pedagogia pela Universidade do Estado da Bahia (2019). Atualmente é pósgraduanda em Psicopedagogia Clínica e Institucional; Monitora voluntária de ensino/extensão da Universidade do Estado da Bahia (UNEB/Campus VIII). Tem experiência na área de Educação, atuando na pesquisa da gestão da sala de aula, professor gestor e autoridade do professor na gestão do espaço sala de aula.

\section{YOLANDA APARECIDA DE CASTRO ALMEIDA}

Professora Adjunta da Universidade do Estado da Bahia, UNEB, Campus X. Graduada em Geografia, Pedagogia, Sociologia. Mestra em Tecnologia Ambiental. Doutora em Geografia pela Pontifícia Universidade de Minas Gerais, PUC Minas. 
